UNIVERSIDADE DE SÃO PAULO

FACULDADE DE ECONOMIA, ADMINISTRAÇÃO E CONTABILIDADE

DEPARTAMENTO DE ECONOMIA

PROGRAMA DE PÓS-GRADUAÇÃO EM ECONOMIA

THALES AUGUSTO ZAMBERLAN PEREIRA

The cotton trade and Brazilian foreign commerce during the Industrial Revolution

\begin{abstract}
Algodão e o comércio internacional do Brasil durante a Revolução
Industrial
\end{abstract}

Versão Corrigida

São Paulo 
Prof. Dr. Marco Antonio Zago

Reitor da Universidade de São Paulo

Prof. Dr. Adalberto Américo Fischmann

Diretor da Faculdade de Economia, Administração e Contabilidade

Prof. Dr. Hélio Nogueira da Cruz

Chefe do Departamento de Economia

Prof. Dr. Marcio Issao Nakane

Coordenador do Programa de Pós-Graduação em Economia 


\section{The cotton trade and Brazilian foreign commerce during the Industrial Revolution}

\section{Algodão e o comércio internacional do Brasil durante a Revolução Industrial}

Tese apresentada ao Programa de Pós-Graduação em Economia do Departamento de Economia da Faculdade de Economia, Administração e Contabilidade da Universidade de São Paulo, como requisito parcial para a obtenção do título de Doutor em Ciências.

Área de concentração: Economia do Desenvolvimento

Orientador: Prof. Dr. Renato Perim Colistete

Versão Corrigida

São Paulo 
Autorizo a reprodução e divulgação total ou parcial deste trabalho, por qualquer meio convencional ou eletrônico, para fins de estudo e pesquisa, desde que citada a fonte.

\section{FICHA CATALOGRÁFICA}

Elaborada pela Seção de Processamento Técnico do SBD/FEA/USP

Pereira, Thales Augusto Zamberlan

The cotton trade and brazilian foreign commerce during the industrial revolution / Thales Augusto Zamberlan Pereira. - São Paulo, 2017. $192 \mathrm{p}$.

Tese(Doutorado) - Universidade de São Paulo, 2017.

Orientador: Renato Perim Colistete.

1. Revolução industrial 2. Algodão 3. Brasil Império 4. Período colonial (1500-1822) I. Universidade de São Paulo. Faculdade de Economia, Administração e Contabilidade. II. Título. 
Nome: Thales Augusto Zamberlan Pereira

Título: Algodão e o comércio internacional do Brasil durante a revolução industrial

Tese apresentada ao Programa de Pós-Graduação em Economia do Departamento de Economia da Faculdade de Economia, Administração e Contabilidade da Universidade de São Paulo, como requisito parcial para a obtenção do título de Doutor em Ciências.

Aprovado em 9 de junho de 2017

\section{Banca Examinadora}

Prof. Dr. William Roderick Summerhill (UCLA) - Externo

Julgamento: Aprovado

Prof. Dra. Maria Alejandra Irigoin (LSE) - Externo

Julgamento: Aprovado

Prof. Dr. André Arruda Villela (EPGE/FGV) - Externo

Julgamento: Aprovado

Prof. Dr. Rafael de Bivar Marquese (FFLCH/USP)

Julgamento: Aprovado 


\section{AGRADECIMENTOS}

Agradeço ao financiamento da Fundação de Amparo à Pesquisa do Estado de São Paulo - FAPESP Processo 2014/04151-6 e Processo BEPE 2015/02414-2. Também agradeço ao Conselho Nacional de Desenvolvimento Científico e Tecnológico (CNPQ) pelo financiamento durante o primeiro ano do doutorado.

Essa tese é resultado do apoio de toda minha família, especialmente Bianca Doeler, minha esposa.

Ao meu orientador, Renato Perim Colistete, pelo apoio constante e conversas ao longo desses anos. Sem a sua ajuda essa jornada não seria possível.

Ao meu coorientador, William Summerhill (e família), pela calorosa recepção em Los Angeles. Ter a oportunidade de desenvolver parte dessa tese na Universidade da Califórnia foi um privilégio.

À Alejandra Irigoin, pela dedicação incansável em ajudar e comentar partes desse trabalho. Além de abrir diversas portas para divulgar os resultados da pesquisa.

Pela minha estadia em Londres como Visiting Fellow do Institute of Latin American Studies, sou grato à Colin Lewis, Rory Miller e Linda Newson.

À Guilherme de Oliveira, colega e vizinho, pelas intermináveis discussões econômicas.

Aos amigos de história econômica de longa data, Thomas Kang, Fabio Pesavento e Sérgio Monteiro.

Aos companheiros de café na UCLA, Leonardo Monasterio, Daniel Franken e Kara Dimitruk.

À Rui Esteves e John Styles, pelos excelentes comentários e recomendações.

Agradeço também aos comentários de Pedro Duarte, Gilberto Tadeu Lima, Felipe Loureiro, Dante Aldrighi, Rafael Marquese, André Villela, Peter Sims, Chris Absell e Knick Harley.

Seminários na FEA/USP, UCLA, LSE, University of London - ILAS, Institute of Historical Research, Oxford - Nuffield College e Economic History Association foram fundamentais no desenvolvimento do trabalho. Além disso, agradeço aos comentários durante o "IV Workshop - New Economic Historians of Latin America" em Madri, e no workshop "Revisions in Modern Brazilian Economic History", em Londres.

Pelas estadias em Cambridge e Londres, obrigado Ildo, Vanessa, Carla, James, Ellen e Francisco. 
"Our responsibility is to do what we can, learn what we can, improve the solutions, and pass them on. It is our responsibility to leave the people of the future a free hand. In the impetuous youth of humanity, we can make grave errors that can stunt our growth for a long time. This we will do if we say we have the answers now, so young and ignorant as we are."

Richard P. Feynman, 1955. 


\section{RESUMO}

Essa tese fornece uma nova interpretação para a ascensão e subsequente declínio do Brasil como um fornecedor de algodão para o setor têxtil britânico durante a Revolução Industrial. Entre 1791 e 1801, o nordeste do Brasil alcançou uma participação de mercado de 40\% em Liverpool. Contrário ao que os pesquisadores normalmente argumentam, a principal causa do surgimento do Brasil como um importante exportador de algodão foi a qualidade superior da sua fibra para os novos têxteis produzidos na Grã-Bretanha. Não obstante o sucesso inicial, as exportações brasileiras de algodão estagnaram após 1819. As interpretações anteriores argumentaram que o declínio das plantações brasileiras de algodão foi resultado da escassez de mão-de-obra e dos altos custos de transporte terrestre. Essa dissertação, no entanto, fornece evidências de que as regiões de algodão no Brasil tinham, de fato, uma alta densidade de escravos. Do mesmo modo, os custos de transporte representaram uma pequena fração dos preços de mercado do algodão. Para os plantadores de algodão, o maior fardo econômico foi a política fiscal implementada pelo governo central após 1808. A necessidade de aumentar as receitas levou o governo central a tributar as commodities mais importantes na época. Os impostos de exportação representaram o maior custo de produção de algodão no Brasil até a década de 1840. Como os governos regionais não podiam tributar as importações, ficaram com poucos recursos para investir em projetos de infraestrutura que poderiam compensar os crescentes custos de tributação. No final, os custos de produção mais elevados reduziram a capacidade do Brasil de enfrentar o desafio de novos concorrentes no mercado internacional do algodão durante o século XIX. 



\begin{abstract}
This dissertation provides a new interpretation for the rise and subsequent decline of Brazil as a cotton supplier to the British textile sector during the Industrial Revolution. Between 1791 and 1801, northeast Brazil achieved a market share of 40 percent in Liverpool. Contrary to what scholars previously argued, the chief cause for the rise of Brazil as a major cotton exporter was its superior cotton fiber for the new calico and muslin textiles produced in Britain. Notwithstanding the initial success, Brazilian cotton exports stagnated after 1819. Previous interpretations argued that the decline of Brazilian cotton plantations was a result of labor shortages and high inland transport costs. This dissertation instead provides evidence showing that cotton regions in Brazil had in fact a high density of slaves. Likewise, transport costs represented a small fraction of cotton market prices. For cotton planters, the largest economic burden was the fiscal policy implemented by the central government after 1808 . The need to increase revenues led the central government to tax the most important commodities at the time. Export taxes represented the largest cost for cotton production in Brazil until the 1840s. As regional governments could not tax imports, they were left with little resources to invest in infrastructure projects that could offset the increasing costs of taxation. In the end, higher production costs reduced Brazil's ability to face the challenge of new competitors in the international cotton market during the nineteenth century.
\end{abstract}




\section{List of Figures}

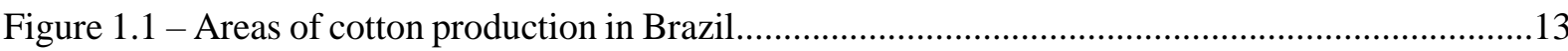

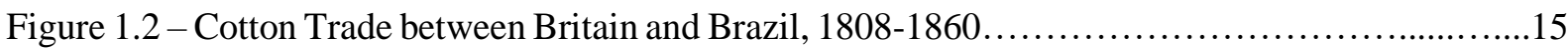

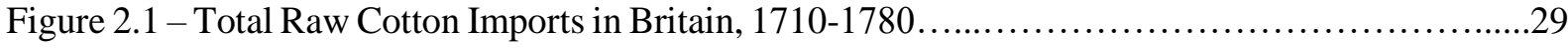

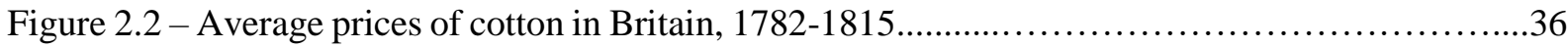

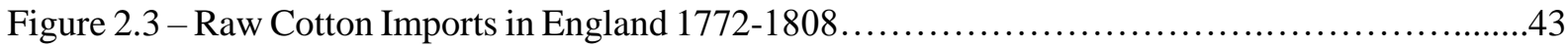

Figure 2.4 - Britain, imports of raw cotton from the West Indies, 1772-1807.......................................45

Figure 3.1 - Share of cotton imports in Liverpool, 1791-1860..........................................................53

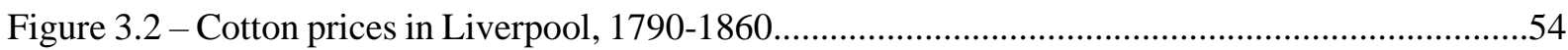

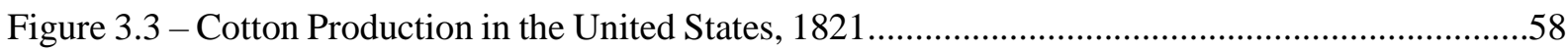

Figure 3.4 - Cotton exports from Maranhão and Pernambuco, 1760-1860..............................................62

Figure 3.5 - Cotton prices in Liverpool 1825 - 1850......................................................................66

Figure 3.6 - Cotton Freight Rates between New York and São Luís to Liverpool....................................68

Figure 3.7 - Cotton prices from Maranhão, Pernambuco, and Bahia 1813-1860....................................69

Figure 3.8 - Maranhão Exports (mil-réis), 1792-1855.........................................................................72

Figure 3.9 - Maranhão Imports (mil-réis), 1792-1855......................................................................73

Figure 3.10 - British trade with Maranhão (£), 1812-1842 ..................................................................75

Figure 3.11 - Exchange Rates in Brazil's main ports, 1818-1841 .......................................................77

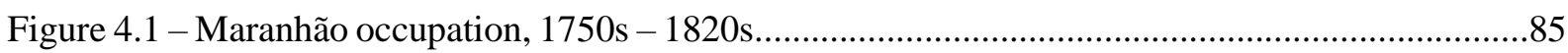

Figure 4.2 - Prices of Maranhão cotton and production cost, 1809-1860...........................................100

Figure 5.1 - Cotton Export Tax in Maranhão, 1809-1850............................................................115

Figure 6.1 - Population estimates for Maranhão, 1800-1872 ...........................................................130

Figure 6.2 - Population estimates for Pernambuco, 1810-1872 ........................................................132

Figure 6.3 - Slaves imports in Maranhão, 1760 - 1850.....................................................................142

Figure 6.4 - Slave prices in Maranhão, Pernambuco, Minas Gerais, and Rio Grande do Sul...............146

Figure 6.5 - Slave prices in South Carolina, New Orleans, and Maranhão..........................................149 
Figure 6.6 - Slave prices in Maranhão, Pernambuco, Minas Gerais, and Rio Grande do Sul (£)..........150 


\section{List of Tables}

Table 2.1 - Portugal raw cotton re-exports to England, 1766-1780...................................................31

Table 2.2 - Share of raw cotton re-exports from European Colonies to England.....................................32

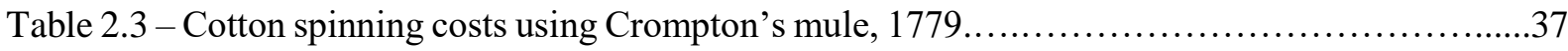

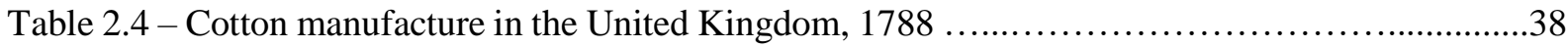

Table 2.5 - Trade between the port of Lisbon and Britain dominions..............................44

Table 2.6 - Share of raw cotton exports to England from the British West Indies.......................46

Table 2.7 - Cotton wool imported in Britain, 1786-1787...................................................................

Table 2.8 - Share of raw cotton exports to England from the British West Indies.................................50

Table 3.1 - Share of cotton production in the United States, 1820s-1840s..........................................61

Table 3.2 - Break Points in weekly Brazilian cotton receipts in Liverpool, 1821-1860..........................64

Table 3.3 - Differences in cotton prices in MA, NY, and Liverpool, 1825-1850.................................67

Table 4.1 - Number of cotton bags produced in Maranhão by location, 1853-58...................................87

Table 4.2 - Maranhão revenues from cotton exports, 1816-1852 ........................................................89

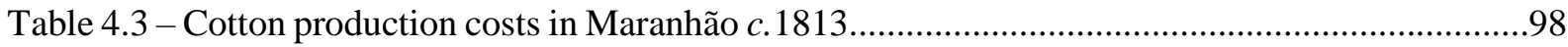

Table 4.4 - Cotton Production and its relationship with slave population...........................................101

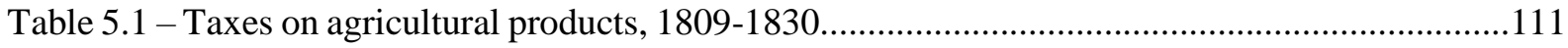

Table 5.2 - Fiscal revenues and expenditures in Maranhão, 1816-1821.............................................112

Table 5.3 - Estimation of demand for Brazilian cotton in UK, 1820-1859........................................121

Table 5.4 - Implied price elasticities of UK demand for Brazilian cotton............................................122

Table 6.1 - Population of the seven bishoprics in Brazil c.1819....................................................127

Table 6.2 - Population estimates for Maranhão, 1798-1872 .............................................................129

Table 6.3 - Population estimates for Pernambuco, 1810-1872 ...........................................................131

Table 6.4 - Population in Maranhão, Pernambuco, Rio de Janeiro, and Alagoas, 1798-1840...............133

Table 6.5 - Population of the United States South, 1800-1840.........................................................135

Table 6.6 - Sex ratio in Brazil and the United States, 1798-1840.......................................................139 
Table 6.7 - Estimates for the population in Maranhão, 1821

Table A.1 - Cotton market and the exchange rate for Maranhão, 1809-1860......................................180

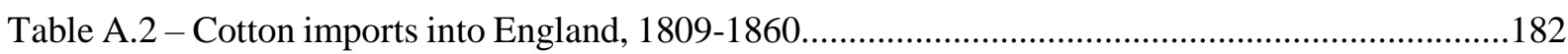

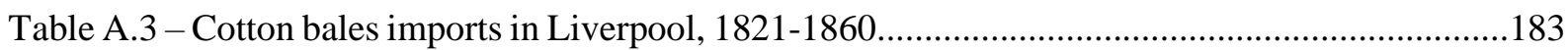

Table A.4 - Freight rates between MA, NY, and Liverpool, 1818-1850 .............................................184

Table A.5 - Production costs for an arroba of cotton in Maranhão, 1809-1860...................................185

Table A.6 - Cotton taxes in Maranhão per arroba, 1809-1850...........................................................186

Table A.7 - Break Points in Cotton Consumption in Liverpool, 1821-1860.......................................188

Table A.8 - Break Points in weekly cotton receipts in Liverpool, 1821-1860.....................................189

Table A.9 - Break Points in Upland cotton prices at New York Port, 1816-1860.................................190

Table A.10 - Cotton demand elasticity, seemingly unrelated regression (SUR) ..................................191

Table A.11 - Cotton demand elasticity, IV (2SLS) estimation..........................................................192 


\section{Table of Contents}

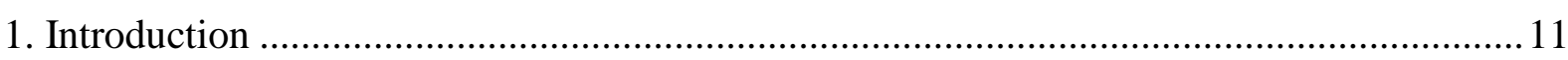

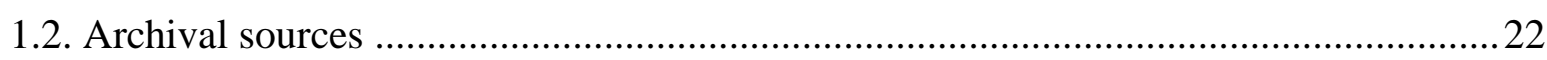

2. The rise of cotton trade in Brazil during the Industrial Revolution......................................24

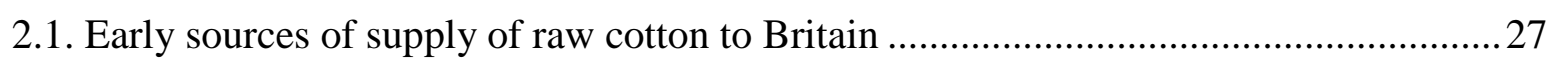

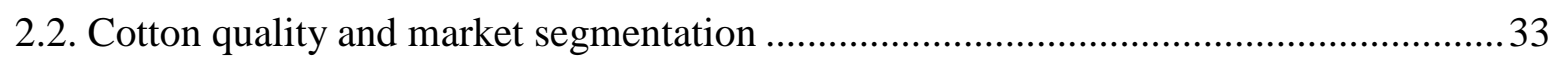

2.3. Portugal and the beginning of cotton production in Brazil ............................................. 40

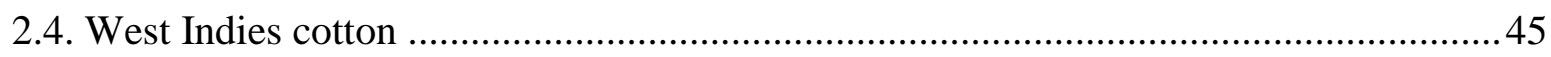

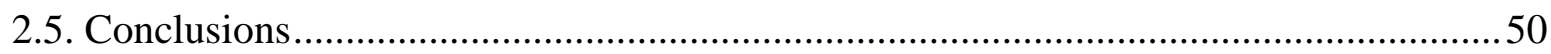

3. International markets and the cotton trade in Brazil, 1800-1860 …...................................52

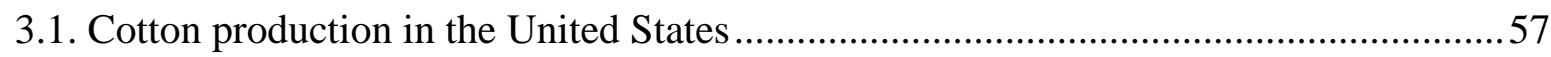

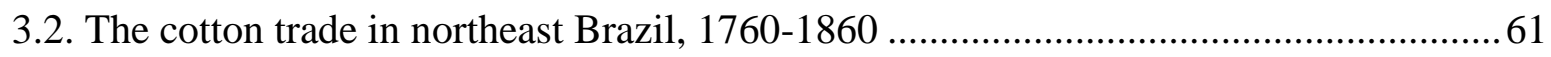

3.3. The balance of trade and exchange rates in northeast Brazil .....................................69

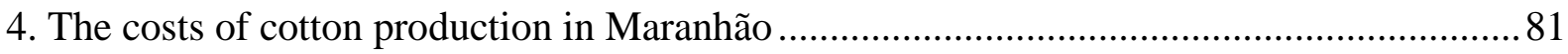

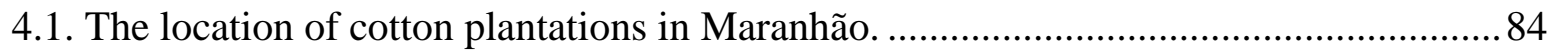

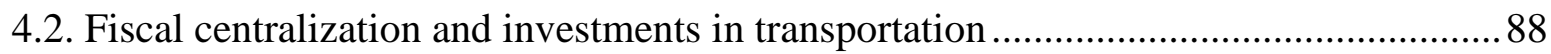

4.3. Production costs in Maranhão's cotton plantations .......................................................94

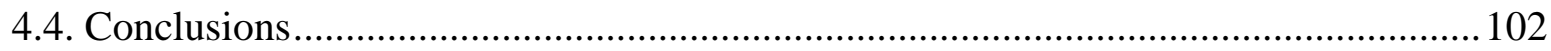

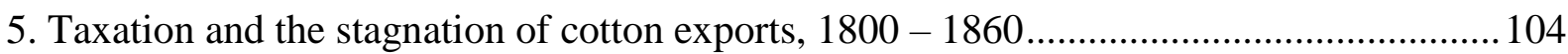

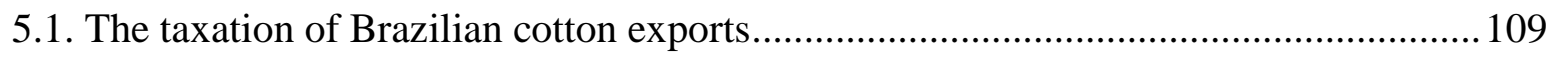

5.2. The optimal export tax for Brazilian cotton............................................................. 118

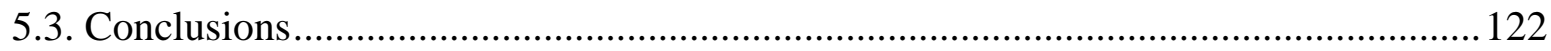

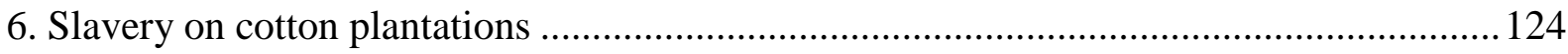

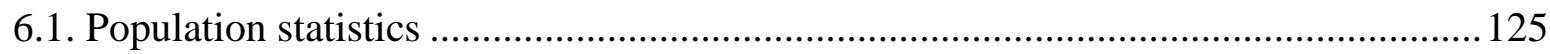

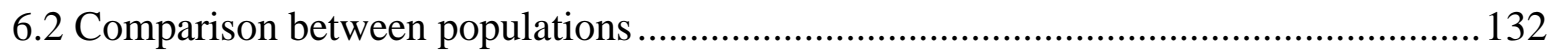

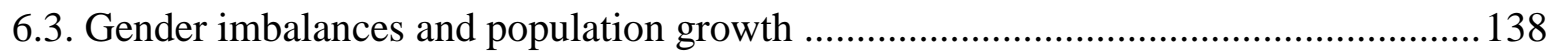

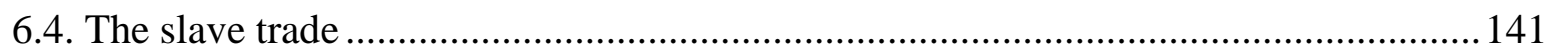

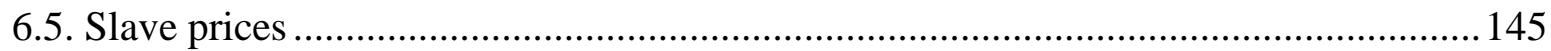

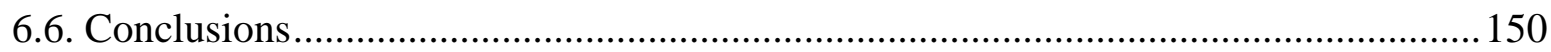

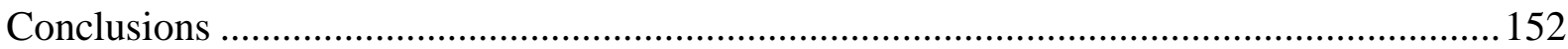

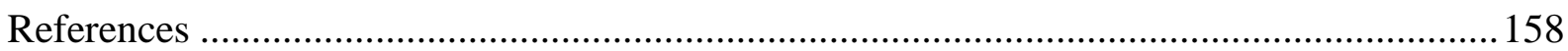

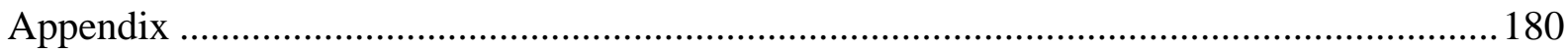




\section{Introduction}

Of all the important events in economic history, the Industrial Revolution is the one that has the largest number of narratives regarding its origins. Early debates about the causes of the Industrial Revolution focused on whether the Revolution affected British society as a whole or just a few industries after $1780 .{ }^{1}$ From these early debates on the scope of changes, scholarship has expanded to analyze the role of institutions, factor prices, the Enlightenment, population dynamics, and consumer preferences in explaining why modern growth occurred early in Britain. ${ }^{2}$ Despite the many different explanations, one fact that permeates the literature on the subject is that cotton was a key sector at the beginning of industrialization. ${ }^{3}$ Cotton cloth has been called the "symbolic consumers' good of the Industrial Revolution." " By the 1830s, the cotton industry represented 50 percent of British merchandise exports, contributing to the country's productivity growth. ${ }^{5}$ While the United States is rightly recognized as the largest supplier of raw cotton throughout the nineteenth century, an oft-neglected fact is that Brazil was also an important cotton exporter to England in the early days of the Industrial Revolution.

The rise of Brazil as a cotton exporter had a direct connection to the "wave of gadgets" that swept Britain starting at the end of the eighteenth century. Although they are sometimes involved in simplistic interpretations of the causes of the Industrial Revolution, the machines that initially increased productivity in cotton spinning - the spinning jenny, the water-frame, and the mule - were a key dimension of a larger story. Between 1770 and 1788, yarn spinning

\footnotetext{
${ }^{1}$ Peter Temin, “Two Views of the British Industrial Revolution," The Journal of Economic History 57, no. 1 (1997): 63-82; T. S. Ashton, The Industrial Revolution 1760-1830, Oxford Paperbacks University Series, v. 38 (Oxford: Oxford University Press, 1968); N. F. R. Crafts and C. K. Harley, "Output Growth and the British Industrial Revolution: A Restatement of the Crafts-Harley View," The Economic History Review 45, no. 4 (1992): 703-30, doi:10.Pat Hudson, The Industrial Revolution, Reading History (London ; New York : New York, NY: E. Arnold ; Distributed in the USA by Routledge, Chapman, and Hall, 1992).2307/2597415; Phyllis Deane and W. A. Cole, British Economic Growth: 1688-1959 (At the University Press, 1969).

${ }^{2}$ Douglass C. North and Barry R. Weingast, "Constitutions and Commitment: The Evolution of Institutions Governing Public Choice in Seventeenth-Century England," The Journal of Economic History 49, no. 4 (1989): 803-32; Robert C. Allen, The British Industrial Revolution in Global Perspective, 1 edition (Cambridge ; New York: Cambridge University Press, 2009); Joel Mokyr, The Enlightened Economy: Britain and the Industrial Revolution, 1700-1850 (Penguin UK, 2011); Gregory Clark, A Farewell to Alms: A Brief Economic History of the World (Princeton University Press, 2008); Deirdre N. McCloskey, Bourgeois Dignity: Why Economics Can't Explain the Modern World (University of Chicago Press, 2011); Jan De Vries, "The Industrial Revolution and the Industrious Revolution," The Journal of Economic History 54, no. 2 (1994): 249-70.

${ }^{3}$ C. Knick Harley, "Cotton Textile Prices Revisited: A Response to Cuenca Esteban," The Economic History Review 52, no. 4 (November 1, 1999): 757, doi:10.1111/1468-0289.00147.

${ }^{4}$ D. N. McCloskey, "The Industrial Revolution 1780-1860: A Survey," in The Economic History of Britain Since 1700 (Cambridge: Cambridge University Press, 1981), 108.

${ }^{5}$ Nicholas Crafts and Nikolaus Wolf, "The Location of the UK Cotton Textiles Industry in 1838: A Quantitative Analysis," The Journal of Economic History 74, no. 4 (December 2014): 1103, doi:10.1017/S0022050714000874.
} 
moved away from wool and linen, and cotton became "the almost universal material for employment." ${ }^{\prime \prime}$ In this connection, two inventions stimulated demand for raw cotton from Brazil. First, the water frame permitted the production of a cotton yarn strong enough to be used as warp, a longer longitudinal thread. Warps allowed cloth to be made entirely with cotton but required a longer cotton fiber than the fiber imported from Eastern Europe and Asia. Powered by water-power, the water-frame rapidly increased spinning productivity, especially after 1785 when its patents expired. ${ }^{7}$

The second key technical innovation for Brazilian cotton was the mule. The mule's main advantage over the spinning jenny and the water-frame was that it could produce the fine yarns used in muslins. This now allowed the cost-effective production in Britain of the high-quality textile that had previously been imported from India. ${ }^{8}$ Indeed, the largest change in productivity in spinning after 1780 was associated with the production of cotton yarns for calicos and muslins; textiles historically associated with India. ${ }^{9}$ With the growing production of all cotton cloths, Lancashire turned to the Americas for its raw cotton because that region produced longer staples than the common Asian varieties.

New machines and new products increased demand for Brazilian cotton in the late 1780s, almost two decades after large scale plantations began to be widespread in northeast Brazil. At the time, the United States did not export raw cotton to Britain as commonly thought: in fact, cotton exports from the United States were virtually nonexistent before $1800 .{ }^{10}$ Rather, Brazil initially had a near monopoly of the raw materials used in the production of fine yarns, especially muslins. Brazilian products represented 40 percent of all raw cotton imports in Liverpool during the 1790s and Brazil continued to be a major supplier to the textile industry until the 1830s. Figure 1.1 shows the main areas of cotton production in Brazil during the nineteenth century. Despite the existence of cotton plantations in São Paulo and on the border

\footnotetext{
${ }^{6}$ William Radcliffe, Origin of the New System of Manufacture: Commonly Called "power-Loom Weaving," and the Purposes for Which This System Was Invented and Brought into Use, Fully Explained in a Narrative, Containing William Radcliffe's Struggles through Life to Remove the Cause Which Has Brought This Country to Its Present Crisis (Stockport: J. Lomax, 1828), 62.

${ }^{7}$ Michael M. Edwards, The Growth of the British Cotton Trade, 1780-1815 (Manchester University Press, 1967), 5.

${ }^{8}$ Prasannan Parthasarathi, Why Europe Grew Rich and Asia Did Not: Global Economic Divergence, 1600-1850 (Cambridge University Press, 2011); Giorgio Riello and Tirthankar Roy, How India Clothed the World: The World of South Asian Textiles, 1500-1850 (BRILL, 2009).

${ }^{9}$ C. Knick Harley, "Cotton Textile Prices and the Industrial Revolution," The Economic History Review 51, no. 1 (1998): 49-83.

${ }^{10}$ Douglass C. North, The Economic Growth of the United States: 1790-1860, First Edition (New York: W. W. Norton \& Company, 1966).
} 
between Bahia and Minas Gerais, until the 1840s, large scale plantations were mostly located in the northeastern provinces, particularly in Maranhão and Pernambuco.

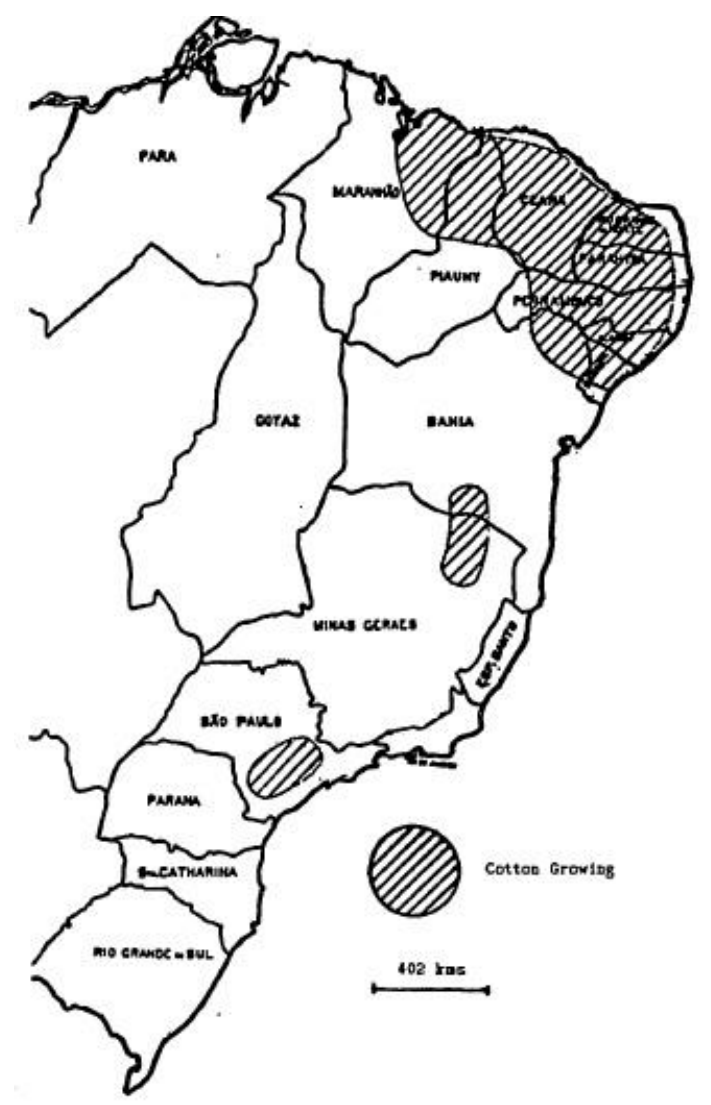

Figure 1.1 - Areas of cotton production in Brazil

Source: Luiz C. Barbosa, "Cotton in 19th Century Brazil: Dependency and Development", p.8.

British textile production continued to develop after 1800, bringing new challenges for Brazilian exporters. Technological improvements in spinning machines reduced the relative demand for long-staple cotton. With higher demand for shorter staples, exports rapidly increased from the United States, laying the foundations for the "Cotton Kingdom." Nevertheless, Brazilian cotton exporters initially kept a significant market share, benefiting from both the Napoleonic blockade and the diplomatic conflicts between the United States and Britain from 1807 to 1815. After that, however, the superiority of North American production was evident and very soon there were fears that the restoration of peace would hit Brazilian exports. The Viscount of Cairú, for example, noted in 1810 that Brazilian cotton would face intense competition when the war ended because the United States had "closer trade relations" with England.$^{11}$ His concern was justified because Brazilian cotton trade was heavily dependent

\footnotetext{
${ }^{11}$ José da Silva Lisboa, Observações Sobre a Franqueza Da Indústria, E Estabelecimento de Fábricas No Brasil (Brasília: Senado Federal, 1999), 81.
} 
on British imports: in the 1810s, 68 percent of the cotton exported from Maranhão - the largest Brazilian exporter at the time - were destined for England, and the export share increased to 83 percent after independence. ${ }^{12}$ Even with the stagnation of cotton production in the following decades, Britain still accounted for 66 percent of Maranhão's total exports in $1861 .^{13}$

The size of Brazil's cotton exports to Britain during the early nineteenth century reveals a different reality from the one portrayed by the literature that examines the end of Portuguese trade monopoly after 1808. This literature usually argues that trade imbalances ruled economic relations between Britain and Brazil. ${ }^{14}$ Figure 1.2, however, shows that Britain's raw cotton imports from Brazil were initially higher than the value of exports of cotton manufactures, which was by far the largest category of item that Britain exported to Brazil. It was only in 1825 that the total value of cotton goods exported to Brazil surpassed the value of raw cotton imported, and this was when, in addition to lower international cotton prices, the Brazilian currency began to devalue and import prices increased. Another way to gage the size of Brazilian cotton trade is to note that Brazil was a major importer of British textiles at the time, with an average trade share of 8 percent before 1850. In comparison, the United States, the largest market for British textiles during the first half of the nineteenth century, represented 11 percent of the total market. ${ }^{15}$

\footnotetext{
${ }^{12}$ Antônio Bernardino Pereira do Lago, Estatística histórico-geográfica da província do Maranhão (Editora Siciliano, 1822); "FO 13/77 - Consuls Baldwin Sealy, Robert Hesketh, William Hesketh, John Hesketh, Foreign Various, and Consular Domestic." 1830, 77, The National Archives, Kew.

${ }^{13}$ Francisco de Assis Leal Mesquita, Vida e morte da economia algodoeira do Maranhão: uma análise das relações de produção na cultura do algodão, 1850/1890 (Universidade Federal do Maranhão, 1987), 213.

${ }^{14}$ Rubens Ricupero, "O problema da Abertura dos Portos," in A abertura dos portos (São Paulo: Editora Senac São Paulo, 2007), 46.

${ }^{15}$ Ralph Davis, The Industrial Revolution and British Overseas Trade (Leicester University Press, 1979), 19; Norman Sydney Buck, The Development of the Organisation of Anglo-American Trade, 1800-1850 (Yale University Press, 1925).
} 


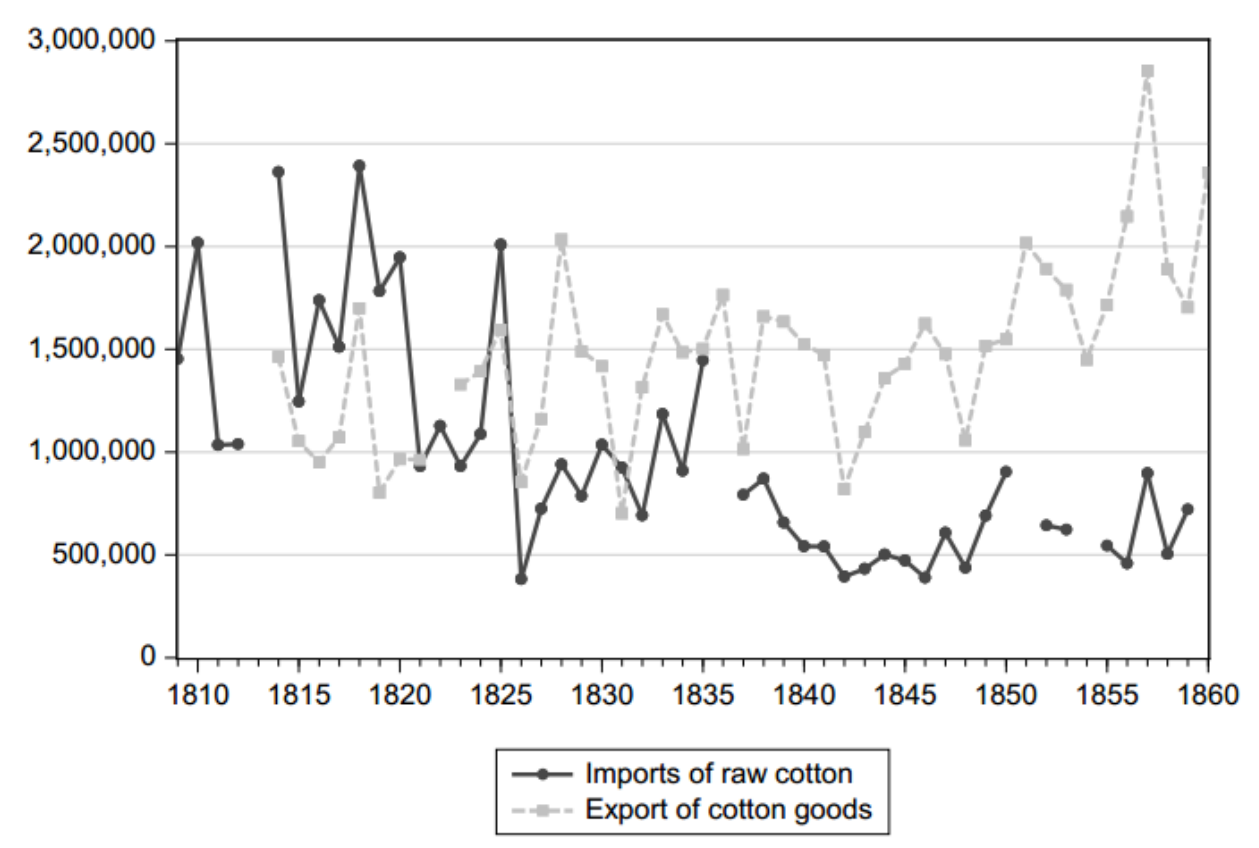

Figure 1.2 - Cotton Trade between Britain and Brazil, 1808-1860 Sources: BNA CUST 9, BNA CUST 4, Liverpool Mercury.

Notwithstanding its initial success, cotton production in Brazil followed a quite different path than that of the United States South in the decades that followed. The stagnation of Brazilian cotton exports set in after international prices fell in 1819, and became worse in the period between 1837 and 1848, when low prices made production unprofitable in some regions. Cotton production expanded only once again; during the United States Civil War in the 1860s. The sudden reversal of fortune for cotton planters in Brazil led to the famous expression by Celso Furtado that the growth during the end of the colonial era had just been a "false euphoria," i.e., export growth was only possible due to atypical conditions in international markets. ${ }^{16}$ Brazil's export stagnation, however, was not the inevitable outcome of lower prices and competition from the United States, because cotton exports from other less developed regions, such as the East Indies and Egypt, grew during the nineteenth century.

Three decades ago, Dauril Alden pointed out that the reason Brazil "wither[ed] away in the face of competition" after two decades of increasing cotton exports was "among the important questions that scholars need to explore." 17 Several causes have been identified by the literature in addition to declining prices: competition from other crops (such as sugar and coffee) for slaves, high transport costs (internal and external), and lack of capital to increase

\footnotetext{
${ }^{16}$ Celso Furtado, Formação econômica do Brasil (Companhia das Letras, 2006), 137.

${ }^{17}$ Dauril Alden, "Late Colonial Brazil, 1750-1808," in Colonial Brazil, ed. Leslie Bethell (Cambridge ; New York: Cambridge University Press, 1987), 322.
} 
productivity. ${ }^{18}$ Moreover, in his analysis of cotton production in Maranhão, Francisco Mesquita argued that the link between competition from the United States and the decline of Brazilian cotton was a “myth.” According to Mesquita, Maranhão's market losses were caused by high production costs, as low productivity meant that its raw cotton was unable to compete in international markets. ${ }^{19}$

Contemporaries who lived in Maranhão during the 1850s pointed to similar causes for the stagnation of cotton production. Eduardo Olimpio Machado, president of this province in 1854, argued that the main problem for cotton plantations was the lack of proper roads and river navigation. The second problem involved the "lack of manpower," as the high price of slaves after 1850 led to an outflow of these workers to the Southern provinces. The third obstacle was the lack of technical education on the part of the workers, which were plagued by "incontestable and recognized ignorance." Finally, according to Machado, inefficient capital markets were also a problem because even those who sought to improve their crops found great difficulty in raising capital. ${ }^{20}$

However, one limitation of these interpretations is that studies such as those by Alice Canabrava, Francisco Mesquita, Luiz Barbosa, and Stanley Stein refer to the years after 1850, when cotton plantations had already been in decline for decades. In fact, Brazil's divergence from other cotton exporters clearly began in the first decades of the nineteenth century, a period when productivity across the Americas seemed roughly similar. Francisco Mesquita hinted to the profitability "paradox" in his research on Maranhão: even during times of high prices and high demand, "something internally already conditioned the depression of the cotton crop," restricting cultivation area and volume of production. ${ }^{21}$ The apparent low profitability achieved by producers could have resulted from market failures, but there is evidence that international cotton markets were competitive and Brazil did not face entry barriers in European markets. ${ }^{22}$

\footnotetext{
${ }^{18}$ Luiz Cordelio Barbosa, "Cotton in 19th Century Brazil: Dependency and Development" (University of Washington, 1989); Stanley J. Stein, Origens e evolução da indústria têxtil no Brasil: 1850-1950 (Rio de Janeiro: Editora Campus, 1979); Nathaniel H. Leff, "Economic Development and Regional Inequality: Origins of the Brazilian Case," The Quarterly Journal of Economics 86, no. 2 (1972): 243-62, doi:10.2307/1880562; Mesquita, Vida e morte da economia algodoeira do Maranhão; Alice P. Canabrava, O Desenvolvimento Da Cultura Do Algodão Na Província de São Paulo, 1861-1875 (São Paulo: EDUSP, 2011).

${ }^{19}$ Mesquita, Vida e morte da economia algodoeira do Maranhão, 229.

20 "Relatorio Do Presidente Da Provincia Do Maranhão, O Doutor Eduardo Olimpio Machado, Na Abertura Da Assembléa Legislativa Provincial No Dia 3 de Maio de 1854, Acompanhado Do Orçamento Da Receita E Despeza Para O Anno de 1855.” (Maranhão, 1854), Center for Research Libraries, Global Resources Network, http://brazil.crl.edu/bsd/bsd/352/.

${ }^{21}$ Mesquita, Vida e morte da economia algodoeira do Maranhão, 230.

${ }^{22}$ Ricardo Hausmann, Bailey Klinger, and Rodrigo Wagner, "Doing Growth Diagnostics in Practice: A 'Mindbook.," Harvard University Center for International Development Working Papers, no. Working Paper No. 177 (September 2008): 23.
} 
Regarding government failures, David Denslow was one of the few who noted that high export taxes could be one of the reasons for the stagnation of cotton exports, but he did not provide evidence to support this hypothesis. ${ }^{23}$

In this dissertation, I provide evidence that the decline in international prices, transport costs, and slave labor shortage are insufficient to explain the stagnation of cotton production in Brazil. I argue that the profitability of cotton plantations was limited by the fiscal policy implemented by the Portuguese government after 1808. High export taxes created disincentives to new investments even during the boom years of cotton exports, when planters did not face constraints in labor supply and had plantations near the coast, which meant lower transportation costs. After independence, fiscal centralization continued and, without the ability to raise revenues, Brazilian provinces were not able to provide public goods to reduce production costs for planters.

Why Brazil's highly centralized political authority, established after 1808, had a direct impact on cotton production through its fiscal policy is not immediately clear. Sokoloff and Zolt argue that, in Latin America, governments could not rely on export duties because they were constrained by "international competition and the power of exporters." ${ }^{24}$ However, in addition to being a source of income for the central government, export taxes also represented an important source of revenue for provinces throughout the monarchic period. ${ }^{25}$ By prohibiting provinces from establishing import duties, the central government imposed a fiscal policy that penalized exports. In Brazil - as was the case in other early developing regions - the social groups which benefited or suffered from fiscal policies are pivotal for explaining inequality in political power. Revenue distribution between central and local governments, which products were taxed, and what sort of spending was prioritized are issues that can reveal important information about the role of governments in economic development. ${ }^{26}$ Historical evidence

\footnotetext{
${ }^{23}$ David Denslow, “As Origens Da Desigualdade Regional Do Brasil,” in Formação Econômica Do Brasil: A Experiência Da Industrialização, ed. Flávio Rabelo Versiani and José Roberto Mendonça de Barros (São Paulo: Saraiva, 1978), 60.

${ }^{24}$ Kenneth Sokoloff and Eric Zolt, "Inequality and the Evolution of Institutions of Taxation: Evidence from the Economic History of the Americas," in The Decline of Latin American Economies: Growth, Institutions, and Crises, by Sebastian Edwards, Gerardo Esquivel, and Graciela Márquez (Chicago: The University of Chicago Press, 2007), 101.

${ }^{25}$ José Murilo de Carvalho, A construção da ordem: a elite política imperial ; Teatro de sombras : a política imperial (Rio de Janeiro: Civilização Brasileira, 2003), 268.

${ }^{26}$ Philip T. Hoffman, "What Do States Do? Politics and Economic History," The Journal of Economic History 75, no. 2 (June 2015): 307, doi:10.1017/S0022050715000637; Noel D. Johnson and Mark Koyama, “Tax Farming and the Origins of State Capacity in England and France," Explorations in Economic History 51 (January 2014): 1-20, doi:10.1016/j.eeh.2013.07.005.
} 
shows that regions lacking proper representation in nations with significant political and geographical divisions can be penalized by region-specific tax rates imposed by distant elites. ${ }^{27}$

Central governments in the early modern period prioritized military expenditure, including servicing debts contracted for financing conflicts. Brazil was no different in a certain sense, and fiscal centralization after 1808 gave rise to new taxation on export products to pay for the augmented government structure and to counteract the impact of the war in Portugal. As sugar and cotton were the most important export products at the time, northern captaincies took a disproportionate share of the fiscal burden under the new policies. Moreover, cotton had the highest taxation of any Brazilian commodity during the early nineteenth century. For example, in Bahia, which exported sugar and cotton, export taxes for sugar between 1812 and 1830 averaged 13 percent of market prices, while for cotton the tax averaged 19 percent. $^{28}$

The colonial legacy left provinces with little autonomy to set their own economic policies, which had detrimental effects for local economic growth. The effects of political centralization in Brazil are reflected in the literature that finds evidence that growth outcomes of economies based on natural resources depend on institutional factors. ${ }^{29}$ With weak rule of law and a malfunctioning bureaucracy, incentives lead potential producers to specialize in "unproductive influence activities." 30 All the more surprising, therefore, that in a country considered to be "an ideal case with which to study the political consequences of a crony economic system," it is only market variables that have usually been considered when examining the causes for the stagnation of the cotton trade. ${ }^{31}$

As I will argue in the following chapters, however, the hypothesis that the stagnation of cotton exports in Brazil resulted from policies of an "oppressive ruler" should not be overstated. Most places in the world, including the U.S. South, had only a limited degree of economic freedom during the nineteenth century, with no enfranchisement and limited access to property

\footnotetext{
${ }^{27}$ Guilherme de Oliverira and Carmine Guerriero, "Extractive States: The Case of the Italian Unification," Working Paper (Columbia Law School, February 10, 2017), 3.

28 "FO 63/215 - Consuls Alexander Cunningham, William Pennell, John Lempriere, Robert Hesketh, John Jeffery, John Crispin, William Harding Read, and Henry Veitch, Etc. (Portugal and Brazil)." 1818, fol. 10, The National Archives, Kew.

${ }^{29}$ Lewis S. Davis, "Scale Effects in Growth: A Role for Institutions," Journal of Economic Behavior \& Organization 66, no. 2 (May 2008): 403-19, doi:10.1016/j.jebo.2006.05.007; Jeffrey A. Frankel and David Romer, "Does Trade Cause Growth?," The American Economic Review 89, no. 3 (1999): 381.

${ }^{30}$ Halvor Mehlum, Karl Moene, and Ragnar Torvik, "Institutions and the Resource Curse," The Economic Journal 116, no. 508 (January 1, 2006): 3, doi:10.1111/j.1468-0297.2006.01045.x.

${ }^{31}$ Stephen Haber, Crony Capitalism and Economic Growth in Latin America: Theory and Evidence (Hoover Institution Press, 2013), xix.
} 
rights. ${ }^{32}$ The crucial difference for cotton production was that the fiscal burden imposed by the Brazilian central government was higher than for other commodities. The government established a fixed-rate export tax in 1808 that eroded planters' profits as cotton prices began to fall after 1819. Moreover, even in the face of the negative impact of lower prices, political centralization delayed actions to solve the crisis and the tax remained in place until the 1830s.

The reasons for the northeast's economic stagnation during a period of growing international demand for one of its main exports have broader implications for understanding Brazil's economic development during the nineteenth century. Given its potential for comparative analysis, the divergent paths in the Americas after European colonization have become an important outcome investigated by scholars who have sought to understand the differences in impact of institutional, social, and economic structures on long-run development. Richard Graham wrote one of the first papers which attempted to compare similar economic patterns in the Americas using Brazil's coffee economy and the United States' cotton South. ${ }^{33}$ At the same time, Graham did stress that one limitation on his research was the difficulty "to find two major processes occurring exactly at the same time," as cotton's importance to international trade occurred much earlier than coffee's. ${ }^{34}$ Comparative studies between the regions in the Americas have resurfaced in the past decades, with research that has linked colonial patterns with institutions and economic growth. ${ }^{35}$

However, despite their achievements and insights, these works tend to draw their analyses on whole regions and to use sweeping generalizations. For example, one limitation to comparing the historical paths of Brazil and the United States is that institutional heterogeneity between the two was sometimes too large to yield useful lessons. Yet, if comparison is restricted to smaller regions such as the U.S. South, the resemblance with Latin America increases, as the U.S. South had lower incomes than its counterpart in the north, slavery was more widespread,

\footnotetext{
${ }^{32}$ Dan Bogart et al., "State and Private Institutions," in The Cambridge Economic History of Modern Europe: Volume 1, 1700-1870, ed. Stephen Broadberry and Kevin H. O'Rourke (Cambridge: Cambridge University Press, 2010), 72; Jeffrey L. Jensen, "Initial Institutions, Institutional Persistence, and the Promotion of Economic Development by the Original 13 States" (PhD Dissertation, New York University, 2010).

${ }^{33}$ Richard Graham, "Slavery and Economic Development: Brazil and the United States South in the Nineteenth Century," Comparative Studies in Society and History 23, no. 4 (October 1, 1981): 622.

${ }^{34}$ Ibid.

35 Daron Acemoglu, Simon Johnson, and James A. Robinson, "The Colonial Origins of Comparative Development: An Empirical Investigation,” American Economic Review 91, no. 5 (December 2001): 1369-1401, doi:10.1257/aer.91.5.1369; Stanley L. Engerman and Kenneth L. Sokoloff, "Factor Endowments, Inequality, and Paths of Development Among New World Economics," Working Paper (National Bureau of Economic Research, October 2002), http://www.nber.org/papers/w9259; Nathan Nunn, "Historical Development," in Handbook of Economic Growth, ed. Philippe Aghion and Steven N. Durlauf, vol. 2, Handbook of Economic Growth (Elsevier, 2014), 347-402, http://www.sciencedirect.com/science/article/pii/B9780444535382000071.
} 
levels of education were lower, and wealth and income inequality much higher than in the northern states. ${ }^{36}$ As Kenneth Pomeranz has argued, when dealing with historical economic divergence smaller regions can reveal "surprising similarities" in agricultural and commercial processes that large political units can obscure. ${ }^{37}$ By studying cotton in Brazil and the United States during the early nineteenth century, several of these limitations are attenuated as heterogeneity in cotton production was much lower. In the years before the railroads, before the end of the slave trade, and the United States' dominance of the international cotton market, Brazil shared many difficulties with other cotton growing regions.

To better understand the rise and fall of cotton production in nineteenth century Brazil, Chapter 2 presents a new interpretation of the possible causes of the rise in Brazilian cotton exports during the last quarter of the eighteenth century. During the 1780s, increased demand for longer staples of cotton for the new calico and muslin textiles led Britain to move away from Asian and Caribbean sources. With demand for a staple that was native to South America, Portugal's economic and political proximity with Britain naturally led Pernambuco and Maranhão to supply the new type of cotton. Contrary to what previous works have argued, the rise of Brazilian cotton trade was not directly related to the revolutions in the United States and the West Indies.

Chapter 3 compares the performance of cotton exports in Pernambuco and Maranhão between 1800 and 1860 to that of Brazil's foreign competitors. In addition to presenting a brief description about cotton production in the United States, the chapter provides new data regarding cotton prices, freight rates, exchange rates, and trade balances in northeast Brazil, to help evaluate some hypotheses about why Brazil's cotton exports stagnated after 1819. Among the interpretations given in previous works, Nathaniel Leff argued that coffee exports created a "Dutch disease" for sugar and cotton production in the northeast. ${ }^{38}$ However, foreign trade data, and information for regional exchange rates, show that Maranhão and Pernambuco had higher

\footnotetext{
${ }^{36}$ Peter H. Lindert and Jeffrey G. Williamson, Unequal Gains: American Growth and Inequality since 1700 (Princeton: Princeton University Press, 2016); Nathan Nunn, "Slavery, Inequality and Economic Development in the Americas: An Examination of the Engerman-Sokoloff Hypothesis," in Institutions and Economic Performance, ed. Elhanan Helpman (Harvard University Press, 2009), 148-80; John Majewski, "Why Did Northerners Oppose the Expansion of Slavery? Economic Development and Education in the Limestone South," in Slavery's Capitalism: A New History of American Economic Development, ed. Sven Beckert and Seth Rockman (Philadelphia: University of Pennsylvania Press, 2016), 277-98.

${ }^{37}$ Kenneth Pomeranz, The Great Divergence: China, Europe, and the Making of the Modern World Economy (Princeton University Press, 2009), 7.

${ }^{38}$ Leff, "Economic Development and Regional Inequality."
} 
exchange rates than the rest of Brazil during the cotton boom. Indeed, exchange rates in the northeast declined after coffee exports began to grow - the opposite of a "Dutch disease."

Therefore, after 1780, foreign demand for Brazilian cotton had a significant impact on the economy of the northeastern provinces, notably Maranhão, which did not export sugar or coffee. Given that Maranhão was more dependent on the cotton trade than other regions, Chapter 4 discusses the costs involved in cotton production in that province, including transport costs, which are often cited as one of the main causes for the low competitiveness of Brazilian exports during the nineteenth century. Although better infrastructure would have benefited planters across the northeast, average production costs between 1809 and 1860 show that transportation was not one of the largest cost components. The analysis of transport costs also demonstrates how fiscal policies in Brazil made it difficult for provinces to provide public goods. Provinces could only levy duties on exports, increasing the fiscal burden on their own products. Attempts by the government of Maranhão to build a major canal and to set up a steamboat company also highlight the problem with political centralization: dependence on the central government for approval and development of infrastructure projects raised costs to the point of rendering them unviable.

Chapter 5 measures the effect of fiscal policies on cotton production. Export taxes were the largest cost for cotton production during the first half of the nineteenth century. The calculation of the optimal export tax for Brazilian cotton shows that planters from Maranhão were more severely affected because they produced short-staple cotton, which put them in competition with highly productive areas in the United States. The long-staple cotton from Pernambuco was still profitable even with higher export taxes, because it supplied different sectors of the textile industry (high quality fabrics) and had less foreign competition.

Chapter 6 discusses the role of slavery in cotton production. Contrary to the literature that has argued that cotton was a "poor's man crop," there was in fact a high demand for slave labor in Maranhão until the 1830s. Slave prices in different provinces show that there was a price premium for Maranhão before 1820, suggesting that there was some increase in productivity. This chapter also examines other important characteristics of slavery, such as sex ratios and fertility rates. 


\subsection{Archival sources}

The early nineteenth century is usually considered as the "statistical dark age" of Latin America, making any temporal or comparative analysis of Brazilian cotton production particularly challenging. ${ }^{39}$ These difficulties are worse at the regional level. Before the 1830 s, Brazil and other Latin American countries did not have institutions to collect trade and government information. The lack of trade data has led scholars to suggest that, in the early decades of the nineteenth century, trade opportunities were limited because Brazilian exports could not match British imports. ${ }^{40}$ As Figure 1.2 showed, however, this was clearly not the case, since raw cotton exports from Brazil were larger than imports of cotton manufactures from Britain.

This dissertation covers the decades around Brazil's independence relying on data from several archival sources. The main source is the British National Archives at Kew. More than 100 volumes of the Ledgers of imports and exports from the United Kingdom (CUST) were consulted, covering the trade relations between Britain and Brazil between 1760 and 1860 . These books record exports and imports from the United Kingdom, by country and commodity (CUST 3, 4, 5, 8, 9, 17). ${ }^{41}$

Another series of documents used is the British consular reports, which provide complementary information on trade conditions in Brazilian ports. These reports are the main sources for exports, imports, duties and taxes, freight rates, exchange rates, and other useful information regarding the province of Maranhão and Pernambuco. Among the books consulted with data from the Foreign Office (FO), the most important are the following:

"Foreign Office and predecessor: Political and Other Departments: General Correspondence before 1906, Portugal" (FO 63). It covers the period before Independence; all consular reports for Brazil during this period were stored in the Portuguese documents. The first book available for Maranhão, which received one of the first British consuls after the arrival of the Portuguese royal family, is the one of 1812. I collected all the information until the last book in 1824.

\footnotetext{
${ }^{39}$ Lindert and Williamson, Unequal Gains, 86.

${ }^{40}$ D. C. M. Platt, Latin America and British Trade, 1806-1914: The Merchant Adventurers (Harper \& Row, 1973), 36.

${ }^{41}$ For a description of these documents, see Appendix A and B in Manuel Llorca-Jaña, The British Textile Trade in South America in the Nineteenth Century (Cambridge ; New York: Cambridge University Press, 2012).
} 
"Foreign Office: Political and Other Departments: General Correspondence before 1906, Brazil” (FO 13). It refers to the years after Independence and provides information on Maranhão (and Permabuco in some years) between 1825 and 1842.

Other documents stored at the British National Archives relevant to understand the cotton trade in Brazil during the colonial period are:

"State Papers Foreign: Portugal" (SP 89). These documents deal with the formation of the Companies of Grão Para and Maranhão and of Pernambuco and Paraíba during the 1750s and 1760s. The monopoly of Brazilian commerce by the Portuguese government raised continuing protests by English merchants. These papers record data on England's role in Brazil's cotton trade before 1808 .

"Board of Trade documents" (code BT 6), that is, reports on the commercial relation of England with other nations and their colonies. These documents made possible the construction of a database containing exports of Brazilian cotton to England before 1808 (BT 6/63). The Board of Trade reports were matched with Portugal's balances of trade, between 1796 and 1808, to evaluate the volume of exports of Brazilian cotton to English ports before the arrival of the royal family in Brazil. In addition, with the document BT 6/140, which deals with the claims of English textile producers during the 1780s against foreign competition, it was possible to evaluate how the quality of Brazilian cotton had an impact on foreign demand.

In addition to the documents at the National Archives, there are three other important sources of information. First, the "Memória Digital" project, carried out by the Brazilian National Library holds an extensive array of digitized newspapers. It allowed the compilation of cotton prices and currency data for Maranhão and follow political debates in the period covered by this dissertation. Second, the British Newspaper Archive provided valuable material, especially the newspaper Liverpool Mercury. The newspaper was the main source for the compilation of international cotton prices. Finally, the Provincial Presidential Reports and other Brazilian government documents digitized by the Center for Research Libraries provided information about the political agenda in the first half of the nineteenth century. 


\section{The rise of cotton trade in Brazil during the Industrial Revolution}

When and why did Brazilian cotton become important for the British Industrial Revolution? During the last two decades of the eighteenth century, exports of cotton manufactures from Britain increased from $£ 355,060$ in 1780 to $£ 5,854,057$ in $1800 .{ }^{1}$ Higher cotton consumption after 1780 was the result of several technological improvements that increased productivity in textile production, which led to raw cotton progressively replacing sheep wool in Britain's textile industry. ${ }^{2}$ Declining costs allowed the production of finer quality fabrics and an increased growth in British industrial exports. ${ }^{3}$ The British West Indies, and some Mediterranean regions, provided most of the raw cotton used in Britain throughout the eighteenth century. With the emergence of calico and muslin production, however, British producers started to look for cotton with longer staples than the Mediterranean could provide, and through Portuguese mediation, Brazil was thus able to increase its relevance to the British textile sector.

During the 1780s and 1790s, with the increased use of the water frame and the spinning mule to spin cotton, both calicoes and muslins needed longer-stapled raw cotton. Cotton grown in South America had the characteristics necessary for producing finer yarns and, given this initial geographic advantage, Brazil provided 40 percent of Liverpool's raw cotton imports between 1791 and 1801, rivalling important traditional suppliers such as the West Indies. The United States had only 10 percent of the Liverpool cotton market at the time because exports of upland cotton were still constrained by ginning technology. ${ }^{4}$ Moreover, upland cotton, despite having a longer staple than the "Asian" species, was of lower quality compared to Brazilian cotton. ${ }^{5}$ By 1800 , cotton accounted for 28 percent of the total value of Portugal's reexports from Brazil, second to sugar, which faced high tariffs in British markets. ${ }^{6}$ Even though cotton markets rapidly increased during the nineteenth century, Brazil remained the second source of cotton for Liverpool until the 1830 s. $^{7}$

\footnotetext{
${ }^{1}$ Sven Beckert, Empire of Cotton: A Global History, First edition (New York: Knopf, 2014).

2 Ashton, The Industrial Revolution 1760-1830, 60; C. Knick Harley, "Was Technological Change in the Early Industrial Revolution Schumpeterian? Evidence of Cotton Textile Profitability," Explorations in Economic History 49, no. 4 (October 2012): 516-27, doi:10.1016/j.eeh.2012.06.004.

${ }^{3}$ Jacob M. Price, "What Did Merchants Do? Reflections on British Overseas Trade, 1660-1790," The Journal of Economic History 49, no. 02 (June 1989): 267-284, doi:10.1017/S0022050700007920.

${ }^{4}$ Angela Lakwete, Inventing the Cotton Gin: Machine and Myth in Antebellum America (JHU Press, 2005).

${ }^{5}$ C. R. Benedict, R. J. Kohel, and H. L. Lewis, "Cotton Fiber Quality," in Cotton: Origin, History, Technology, and Production, ed. C. Wayne Smith and J. Tom Cothren, 1 edition (New York: Wiley, 1999), $269-87$.

${ }^{6}$ Alden, "Late Colonial Brazil, 1750-1808," 322.

${ }^{7}$ Henry Smithers, Liverpool, Its Commerce, Statistics, and Institutions: With a History of the Cotton Trade (T. Kaye, 1825); Alexey Krichtal, "Liverpool and the Raw Cotton Trade: A Study of the Port and Its Merchant Community, 1770-1815” (Victoria University of Wellington, 2013).
} 
The connection between Brazilian cotton and British textile production has already been highlighted by scholars in the past. ${ }^{8}$ Roberto Simonsen, in 1937, and Caio Prado Jr., in 1942, observed that the rise in cotton consumption by English factories fostered Brazilian cotton exports after 1770. Almost all Brazilian cotton came from Maranhão and Pernambuco (which originally occupied larger geographical areas in their previous political divisions). While cotton in Pernambuco had achieved as much importance as sugar by the end of the eighteenth century, cotton was Maranhão's main export and launched a "golden age" that lasted until the first quarter of the nineteenth century. ${ }^{9}$ The increase in exports was part of Brazil's resurgence in agricultural production that helped reinvigorate Portugal's economy at the end of the eighteenth century. Through re-exports from Lisbon, Brazilian cotton went overwhelmingly to Britain and became the centerpiece in the reversal of the trade balance between the two countries, a desired economic outcome in the mercantilist age. ${ }^{10}$ Manchester newspapers often advertised cotton from Maranhão, Pernambuco, or simply "Brazil" in the $1790 \mathrm{~s} .{ }^{11}$

Scholars have offered two complementary explanations for Brazil's rise as a cotton exporter to Britain. One of these explanations argues that the United States' War of Independence, between 1775 and 1783, enabled the rise of Brazilian cotton. ${ }^{12}$ The problem with this argument is that North America did not export cotton to Britain before 1790. ${ }^{13}$ Another (and more influential) explanation in the literature is related to the revolutions in the British and French Caribbean colonies in the last decade of the eighteenth century, combined with Portuguese neutral stance in Europe's political upheavals. ${ }^{14}$ The revolutions disrupted

\footnotetext{
${ }^{8}$ Alan Krebs Manchester, British Preeminence in Brazil: Its Rise and Decline : A Study in European Expansion (Octagon Books, 1964); Platt, Latin America and British Trade, 1806-1914.

${ }^{9}$ Roberto Simonsen, História Econômica Do Brasil (1500/1820) (Rio de Janeiro: Brasiliana, 1967), 369-70.

${ }^{10}$ A. R. Disney, A History of Portugal and the Portuguese Empire: From Beginnings to 1807, vol. 2 (Cambridge University Press, 2009), 283; Fernando A. Novais, Portugal e Brasil na crise do antigo sistema colonial (17771808) (Editora HUCITEC, 1979), 189.

11 "To Be Sold, by Action," Manchester Mercury, March 13, 1787, 1866 edition, 4; "Cotton Business," Manchester Mercury, December 28, 1790, 2064 edition, 1, The British Newspaper Archive.

${ }^{12}$ Andrée M. Silva, "Imperial Re-Organization, 1750-1808," in Colonial Brazil, ed. Leslie Bethell (Cambridge ; New York: Cambridge University Press, 1987), 270; Manuel Nunes Dias, A Companhia Geral do Grão Pará e Maranhão (1755-1778). (Universidade de São Paulo, Faculdade de Filosofia, Letras e Ciências Humanas, 1971), 372; Charles Ralph Boxer, The Portuguese Seaborne Empire, 1415-1825 (Hutchinson, 1969), 206. Evaldo Cabral de Mello, A outra independência: o federalismo pernambucano de 1817 a 1824 (Editora 34, 2004), 58; Peter L. Eisenberg, The Sugar Industry in Pernambuco: Modernization Without Change, 1840-1910 (University of California Press, 1974); José Jobson Andrade de Arruda, "O Algodão Brasileiro Na época Da Revolução Industrial," América Latina En La Historia Económica 23, no. 2 (May 2, 2016): 167-203.

${ }^{13}$ Sydney John Chapman, The Lancashire Cotton Industry: A Study in Economic Development (Manchester: University Press, 1904), 143; Thomas Ellison, The Cotton Trade of Great Britain: Including a History of the Liverpool Cotton Market and of the Liverpool Cotton Brokers' Association (London: Effingham Wilson, 1886), 81; E. J. Donnell, Chronological and Statistical History of Cotton. (New York: J. Stutton \& co., printers, 1872), 49, http://catalog.hathitrust.org/Record/000957820.

${ }^{14}$ Caio Prado Jr, Formação do Brasil contemporâneo (Editora Brasiliense, 1948), 125.
} 
production in the islands and Brazil became the short-term alternative replacement for the Caribbean supply. However, this chapter draws upon newly collected archival data on the British cotton trade and shows that Britain managed to acquire important territories from the Netherlands during the 1790s that allowed a continuous expansion of the cotton supply from the West Indies. As such, the Caribbean revolutions could not have had the effect on cotton exports from Brazil that some scholars have stated.

This chapter argues that rather than being connected to market shocks, the increase in Brazilian cotton exports was related to changes in the quality of the fabrics during the early stages of the Industrial Revolution. Previous research by Giorgio Riello, John Styles, and others has shown that innovation in textile production during the early period of the Industrial Revolution was not only about new machinery, but also about improved materials. ${ }^{15}$ The lighter, better-quality fabrics that emerged after 1780, such as calicoes and muslins, benefited from the largest decline in prices among textiles at the end of the eighteenth century and required a different variety of cotton than the one previously used in Britain. ${ }^{16}$ The quality of Brazilian cotton, with its longer and more resistant fibre, was the crucial aspect that gave it an initial advantage when cotton manufacturing began to produce better cloths using new spinning technology. Maranhão and Pernambuco were able to meet Britain's growing demand after 1780 due to the previous incentives to develop cotton plantations in Brazil - aimed to support Portuguese textile production - launched during Pombal's administration.

Evidence supporting these arguments comes from several archival sources, some of which deserve closer examination. The first of these is provided by the British Ledgers of Imports and Exports, which list trade figures between British ports and foreign countries until $1780 .{ }^{17}$ The second source is contained in the statistical tables from the Inspector General of Imports and Exports, presented in the States of Navigation, Commerce and Revenue, provide foreign trade data between 1772 and $1808 .{ }^{18}$ The foreign trade books tabulate the quantity and the "official value" for different products, although only the figures related to quantities are

\footnotetext{
${ }^{15}$ Giorgio Riello, Cotton: The Fabric That Made the Modern World (Cambridge University Press, 2013), 154; John Styles, "Fashion, Textiles and the Origins of Industrial Revolution," East Asian Journal of British History 5 (March 31, 2016): 161-89; Mokyr, The Enlightened Economy, 143; S. D. Chapman, "Quantity Versus Quality in the British Industrial Revolution: The Case of Printed Textiles," Northern History 21, no. 1 (January 1, 1985): 182, doi:10.1179/007817285790176156.

16 Harley, "Cotton Textile Prices and the Industrial Revolution."

17 "Ledgers of Imports and Exports" (volume(s), 1780 1697), CUST 3, The National Archives, Kew.

18 "States of Navigation, Commerce and Revenue" (volume(s), 1808 1772), CUST 17, The National Archives, Kew.
} 
useful, since official values were recorded in fixed prices from 1696, not market prices. ${ }^{19}$ Other documents were used to check for data consistency: Portuguese trade balances, reports from textile manufacturers in Manchester, as well as documents from the British Board of Trade, the Colonial Office, and the Foreign Office.

The following sections explain why Brazilian cotton became a key supplier to the Britain during the Industrial Revolution, between 1760 and 1808. With the emergence of mechanized yarn production, the longer fiber of the Brazilian cotton gave it a natural advantage over species cultivated in other regions because it could be used for the warp in cotton textiles. In terms of supply, cotton plantations in Brazil managed to rapidly respond to Britain's increasing demand after the 1780 s by taking advantage of the policies adopted by the Portuguese government to promote Portugal's cotton industry in the 1760s. The last section of the chapter provides new information that does not support previous explanations about the West Indies' role in the rise of Brazilian cotton trade. Cotton from the West Indies was not a viable alternative to Brazilian cotton because it was not used to produce finer calicoes, muslins, and other high-quality products, such as hosiery.

\subsection{Early sources of supply of raw cotton to Britain}

Which countries and regions were the traditional suppliers to the British cotton market and what was the Brazilian share? The end of the eighteenth century saw cotton goods gradually replacing woolen goods in British textile manufacturing. Cotton was already being imported by British producers at the beginning of the eighteenth century, but quantities remained low until the $1740 \mathrm{~s} .{ }^{20}$ After a steady rise in the decades that followed, the emergence of new technology such as spinning machines produced an increase in raw cotton consumption "from 5 million (pounds) in 1780 to 22 million in 1787."21 During the last two decades of the eighteenth century, cotton was the fastest-growing sector in the British economy, while other textile industries, such as woolens, stagnated. ${ }^{22}$

\footnotetext{
${ }^{19}$ Albert H. Imlah, "Real Values in British Foreign Trade, 1798-1853," The Journal of Economic History 8, no. 02 (November 1948): 133-152.

${ }^{20}$ Ellison, The Cotton Trade of Great Britain, 15.

21 Alfred P. Wadsworth and Julia De Lacy Mann, The Cotton Trade and Industrial Lancashire, 1600-1780 (Manchester University Press, 1965), 521.

${ }^{22}$ N. F. R. Crafts, British Economic Growth during the Industrial Revolution (Oxford: Clarendon, 1985); McCloskey, "The Industrial Revolution 1780-1860: A Survey," 114.
} 
Notwithstanding the textile industry's high output growth rate in the 1760 s, increasing prices raised fears about cotton scarcity and alarmed the textile industry. ${ }^{23}$ John Styles argues that this initial shortage created incentives to produce finer yarn that could reduce the amount of cotton required. ${ }^{24}$ In 1766 , before the adoption of better spinning technologies, to mitigate possible shortages, the government enacted the Free Port Act, which allowed trade with some French and Spanish colonies. The Act - renewed in 1774 - contained a clause abolishing the duty of 4.5 percent on raw cotton imports. ${ }^{25}$ In the 1770 s, both the mechanization of cotton spinning and the end of laws requiring linen to be used in some cotton textiles (usually for warps) were the first steps that increased production of finer yarns, turning cotton into a commercial success. ${ }^{26}$ Before 1770 , the use of linen was also a necessity, since the spinning technology could not produce a thread strong enough to serve as the warp. ${ }^{27}$

The increased demand for British calicoes and muslins during the late eighteenth century was the result of higher domestic income and increasing foreign demand. ${ }^{28}$ In addition to the sales of coarse cotton used by slaves in New World plantations, the expansion of cotton production in the final years of the eighteenth century was closed linked to the finer textiles which were in particular demand by the high wage economy of British North America. ${ }^{29}$ Around 1790 , foreign trade in cotton textiles was growing so fast that manufacturers were unable to meet overseas demand..$^{30}$

Figure 2.1 collates information on Britain's raw cotton imports before the productivity increase in cotton manufacturing during the 1780s and 1790s. Despite the rise in imports after the Free Port Act of 1766, the British textile industry was able to increase its supply of foreign cotton not from the Caribbean, but through Smyrna cotton, imported from Turkey. Between 1768 and 1777, the decade after the first Free Port Act, Turkey exported approximately 10

\footnotetext{
${ }^{23}$ Wadsworth and Mann, The Cotton Trade and Industrial Lancashire, 1600-1780, 523.

${ }^{24}$ Styles, "Fashion, Textiles and the Origins of Industrial Revolution," 185.

${ }^{25}$ Wadsworth and Mann, The Cotton Trade and Industrial Lancashire, 1600-1780, 191. Demands for raw cottons constituted one of several petitions regarding trade that led to the Free Port Acts. For a detailed discussion see Frances Armytage, The Free Port System in the British West Indies: A Study in Commercial Policy, 1766-1822 (Longmans, Green and Co., 1953), 28-32.

${ }^{26}$ Patrick O’Brien, Trevor Griffiths, and Philip Hunt, "Political Components of the Industrial Revolution: Parliament and the English Cotton Textile Industry, 1660-1774," The Economic History Review 44, no. 3 (1991): 415, doi:10.2307/2597536.

${ }^{27}$ Riello, Cotton, 153.

${ }^{28}$ Edwards, The Growth of the British Cotton Trade, 1780-1815, 42; Allen, The British Industrial Revolution in Global Perspective, 34.

${ }^{29}$ Styles, "Fashion, Textiles and the Origins of Industrial Revolution," 181-83; Lindert and Williamson, Unequal Gains.

${ }^{30}$ Joseph E. Inikori and Stanley L. Engerman, The Atlantic Slave Trade: Effects on Economies, Societies and Peoples in Africa, the Americas, and Europe (Duke University Press, 1992), 165.
} 
million pounds of cotton, accounting for 56 percent of total cotton imports from foreign nations. ${ }^{31}$ Italy, which re-exported cotton from the Levant (present-day Syria and Lebanon), was the second supplier of Mediterranean cotton. Even with an increase in exports, French and Spanish islands in the Caribbean represented only 6.6 percent of the cotton supply. Throughout the decade, the British West Indies continued to be the main supplier of raw cotton, exporting around 30 million pounds of cotton, with Dominica, Grenada, and Jamaica accounting for 65.5 percent of total trade. ${ }^{32}$

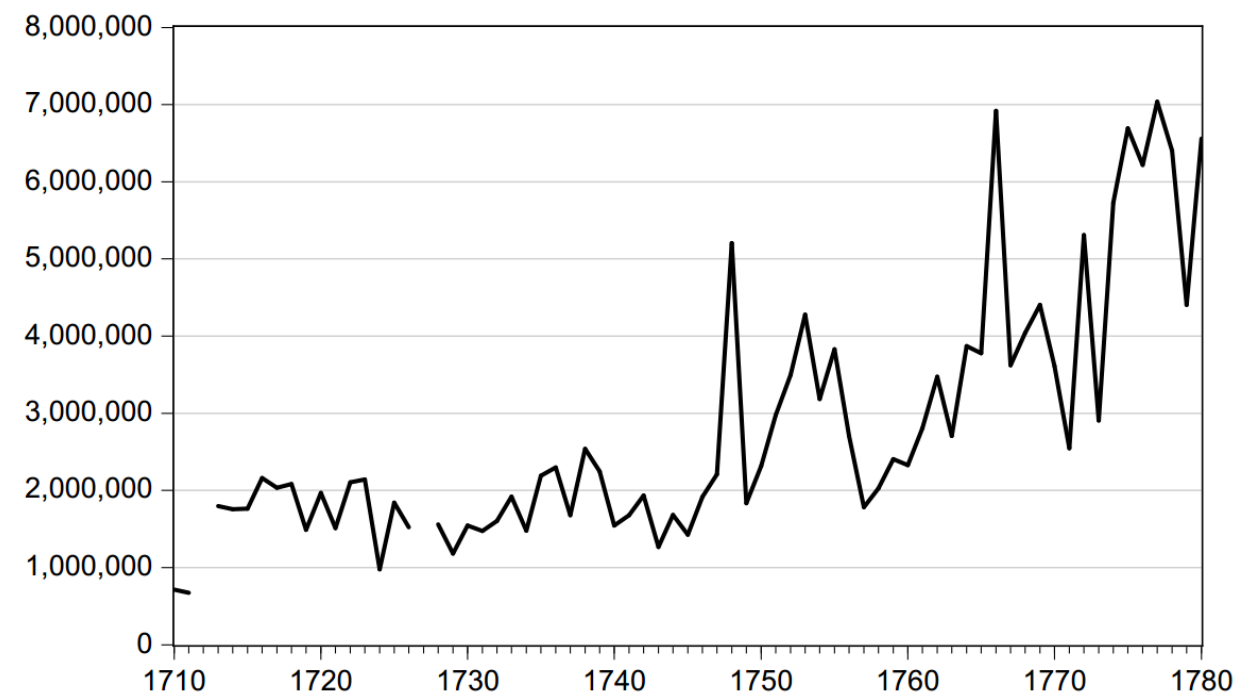

Figure 2.1 - Total Raw Cotton Imports in Britain, 1710-1780 (pounds)

Source: Alfred Wadsworth; Julia Mann. The Cotton Trade and Industrial Lancashire, 521

Before the 1780s, Brazil's participation in the British cotton market was still negligible. Britain first noticed Maranhão's economic potential in 1753 when the British consul in Lisbon, reporting on the departure of ships to Rio de Janeiro and Maranhão, stated that the latter was an "improving colony" abounding with "coffee, cocoa, sugar, tobacco, and cotton." 33 However, initial interest in Maranhão was focused on its rice production, rather than cotton. In a 1767 report, the British consul observed that the increase in rice exports from Maranhão could "render unnecessary the cargo supplies which this kingdom now receives from South Carolina." ${ }^{34}$ Cotton initially received scant attention from the British consul because it was not exported in the 1750s. Despite some evidence that Maranhão cotton was first exported in 1749,

\footnotetext{
31 “The National Archive of the UK T 64/275/143" February 1779, The National Archives, Kew.

${ }^{32}$ Quantity of cotton wool imported from British Colonies; from "The National Archive of the UK T 64/275/142" February 1779, The National Archives, Kew.

33 “The National Archive of the UK SP 89/49/54" June 10, 1753, fol. 109, The National Archives, Kew.

34 “The National Archive of the UK SP 89/67/7" January 14, 1769, The National Archives, Kew.
} 
most accounts point to 1760 as the first shipment to Portugal. ${ }^{35}$ Exports of raw cotton from Pernambuco to Portugal began in 1778 , but the volume was not significant until $1781 .^{36}$

Nineteenth-century writers studying the cotton trade, such as Smithers (1825), Baines (1835) and Branner (1885), dated Brazilian cotton's first export to England to $1781 .{ }^{37}$ Smithers noted that there was a very dirty cotton "from Maranham." ${ }^{38}$ Subsequent studies point to an even earlier date -1767 - when Britain imported approximately $£ 6$ of cotton from Brazil. ${ }^{39}$ James Lang also argued that much of Maranhão's cotton production between 1768 and 1778 was destined for England. ${ }^{40}$ In the British trade ledgers from 1697 to 1780 , the first entry for raw cotton of Portuguese provenance appears in $1766 .{ }^{41}$ Moreover, a Treasury document entitled "an account of all cotton wool of foreign growth imported into England," containing date on the period between 1768 and 1799, shows cotton coming from Portugal in 1769. ${ }^{42}$ Table 2.1 compares the data from the Customs House with documents from Robert Walpole, the British consul in Lisbon in the 1770s, and shows that despite the existence of imports in the 1760 s, it was only in the 1770s that cotton from Brazil became relevant to British manufacturers.$^{43}$ Reports from British merchants listing the commodities that were exported from Maranhão and Pernambuco during the 1760s also show that cotton was not considered an important product. ${ }^{44}$

\footnotetext{
${ }^{35}$ Arruda, O Brasil no comércio colonial, 615; Jerônimo de Viveiros, História do comércio do Maranhão, vol. 1 (São Luís: Associação Comercial Maranhão, 1954); Cesar Augusto Marques, Diccionario historico-geographico da provincia do Maranhão (Maranhão: Typ. do Frias, 1870), http://www2.senado.leg.br/bdsf/handle/id/221726.

${ }^{36}$ Manuel Arruda da Camara, Memoria Sobre a Cultura Dos Algodoeiros E Sobre O Methodo de O Escolher, E Ensacar (Lisboa: Officina da Casa Litteraria, 1799), 7.

37 The information from Branner (1885) is from Joseph Lyman's book from 1868, "Cotton Culture with an Additional Chapter on Cotton Seed and its uses."

${ }^{38}$ Smithers, Liverpool, Its Commerce, Statistics, and Institutions, 155.

39 Violet Mary Shillington and Annie Beatrice Wallis Chapman, The Commercial Relations of England and Portugal (G.Routledge \& sons, 1907).

${ }^{40}$ James Lang, Portuguese Brazil: The King's Plantation (Academic Press, 1979), 163.

41 "Ledgers of Imports and Exports."

42 "The National Archive of the UK T 64/275/143."

43 "The National Archive of the UK SP 89/77/24" July 4, 1774, The National Archives, Kew.

44 "Further Extract from Memorials of the British Consul and Factory at Lisbon," The Caledonian Mercury, December 13, 1766, 6927 edition, The British Newspaper Archive.
} 
Table 2.1 - Portugal's raw cotton re-exports to England, 1766-1780

\begin{tabular}{|c|c|c|c|c|}
\hline Date & Bags & $\begin{array}{l}\text { ort of London (1 } \\
\text { Pounds Weight }\end{array}$ & Value $(£)$ & $\begin{array}{l}\text { All Ports (2) } \\
\text { Pounds Weight }\end{array}$ \\
\hline 1766 & 0 & 10,410 & 303 & No data \\
\hline 1767 & 1 & & 5 & No data \\
\hline 1768 & 0 & 0 & 0 & 0 \\
\hline 1769 & 4 & & 319 & 47,677 \\
\hline 1770 & 0 & 0 & 0 & 0 \\
\hline 1771 & 0 & 0 & 0 & 0 \\
\hline 1772 & & 1,680 & 54 & 112,461 \\
\hline 1773 & 6 & 63,700 & 2,095 & 64,900 \\
\hline 1774 & & 79,500 & 2,567 & 79,500 \\
\hline 1775 & & 41,360 & 1,206 & 41,360 \\
\hline 1776 & & 19,500 & 568 & 19,500 \\
\hline 1777 & 5 & 20,000 & 615 & 21,000 \\
\hline 1778 & 27 & 29,000 & 1,021 & No data \\
\hline 1779 & 43 & 7,400 & 495 & No data \\
\hline
\end{tabular}

Source: (1) Ledgers of imports and exports - CUST 3; (2) Treasury, Trade Returns - T 64/275/143

Brazil's growing share in the British cotton trade after 1780 first came about following a realization by the British that the British West Indies could not increase their exports at the rate demanded by the textile industry. Not only did cotton from islands in the Caribbean have to compete for space with other profitable commodities, such as sugar, but in addition, the new production of muslins and calicoes required a different quality of cotton from that provided by Mediterranean sources. The demand for Smyrna cotton, which was used to produce fustians (heavy textiles) and coarser cloths, began to decline around the end of the eighteenth century because its short staple and strength were not suitable for the increasingly mechanized processing of yarns..$^{45}$ Levant cotton was also inferior to West Indies cotton, its fibers considered a "physical objection" to the production of anything but coarse goods. ${ }^{46}$

The increasing mechanization of cotton textile production after 1780 made the demand for longer and resistant fibers to be used as warp soar. Most of the new demand was for species from the Americas, initially from Brazil and later - with improvements in gins for processing the "fuzzy-seed" upland cotton - from the United States. ${ }^{47}$ Stimulated by the "representations of the English manufacturers," traditional suppliers such as the East India Company initially attempted, without success, to improve the quality of cotton exported to England from Asian

\footnotetext{
${ }^{45}$ Riello, Cotton; Styles, "Fashion, Textiles and the Origins of Industrial Revolution," 177.

${ }^{46}$ Wadsworth and Mann, The Cotton Trade and Industrial Lancashire, 1600-1780, 185; 189; Charles Mackenzie, Facts, Relative to the Present State of the British Cotton Colonies: And to the Connection of Their Interests with Those of the Mother Country (Edinburgh: T. Bryce \& Co, 1811), 18.

${ }^{47}$ Lakwete, Inventing the Cotton Gin, 2-3.
} 
sources. ${ }^{48}$ The adoption of British machinery by U.S. manufacturers in the early days of industrialization serves as an example of the importance of different cotton species in production. As spinning initially used mainly Cayenne and Surinam cotton (related to the Brazilian species), cotton manufacturers in Massachusetts planned to petition Congress in 1791 for an additional duty on imported cotton goods, aiming to apply the duty for "raising [...] cotton in the southern states, of a quality and clearness suitable to be wrought by machines." 49

Table 2.2 - Share of raw cotton re-exports from European Colonies to England (\%)

\begin{tabular}{lrrrrrr}
\hline Period & Portugal & Holland & France & Spain & Italy & Turkey \\
\hline $1768-1771$ & 1.0 & 7.8 & 0.8 & 3.1 & 30.4 & 55.0 \\
$1772-1775$ & 5.0 & 13.7 & 5.6 & 2.5 & 22.7 & 44.9 \\
$1776-1779$ & 2.2 & 15.2 & 0.9 & 5.7 & 7.5 & 59.7 \\
$1780-1783$ & 9.4 & 22.8 & 2.8 & 0.0 & 17.9 & 7.7 \\
$1784-1787$ & 21.5 & 19.3 & 25.5 & 1.7 & 9.3 & 24.2 \\
$1788-1791$ & 33.5 & 9.8 & 24.1 & 0.5 & 3.3 & 21.0 \\
$1792-1795$ & 37.7 & 10.5 & 6.2 & 7.3 & 7.5 & 23.5 \\
$1796-1799$ & 67.4 & 0.7 & 0.0 & 4.4 & 1.4 & 4.7 \\
$1800-1803$ & 77.9 & 0.5 & 0.4 & 0.5 & 1.1 & 12.5 \\
$1804-1807$ & 96.0 & 0.0 & 0.2 & 1.8 & 0.1 & 4.4 \\
\hline
\end{tabular}

Sources: 1768-71, Custom House (BNA T 64/275/143); 1772-1807, State of Navigation, Commerce and Revenue (BNA CUST 17)

Table 2.2 presents Britain's imports of raw cotton from European colonies and shows the decline after 1780 from "eastern sources," such as Turkey and Italy. Holland, with its colonies Demerara and Surinam, was also an important supplier before it went to war against Britain in 1781. France's re-exports from its colonies in the West Indies temporarily increased after 1780, until fierce disputes with Britain flared up again a decade later. By contrast, Portugal's continued growth after 1783 stands out.

One aspect worth mentioning regarding trading data for the end of the eighteenthcentury concerns smuggling. Several authors argue that the Portuguese trade monopoly, in a period of increasing demand for raw cotton in international markets, led to an increase in illicit trade by British merchants on the Brazilian coast. ${ }^{50}$ However, as smuggling was a widespread activity and affected other regions as well, it seems fair to assume that it did not create a significant bias in the data for cotton imports from Portugal. ${ }^{51}$ Illegal trade was also rampant

\footnotetext{
${ }^{48}$ Donnell, Chronological and Statistical History of Cotton., 44.

49 Ibid., 53.

50 Because of smuggling, in 1776 Pombal issued an edict banning English colonies vessels from docking at Brazilian ports. Novais, Portugal e Brasil na crise do antigo sistema colonial (1777-1808), 177.

${ }^{51}$ Contemporary reports show contraband between the West Indies and Brazil: "The Island of Martinique," The Times, May 2, 1794, 2978 edition, 3, The Times Digital Archive 1785-2006 (Gale).
} 
between English and Dutch colonies in the Caribbean and with the United States. ${ }^{52}$ With this caveat, the next section explains in more detail the relation between cotton quality and the rise of Brazilian cotton trade at the end of the eighteenth century.

\subsection{Cotton quality and market segmentation}

The species of cotton cultivated in Brazil is crucial for explaining the increase in imports by British textile manufacturers during the last two decades of the eighteenth century. British production of calicoes, previously imported from India, began in 1773 and rapidly affected the imports of raw cotton..$^{53}$ Smyrna cotton, which was the variety of cotton most in demand outside the West Indies, could not be used for the warp in the new cotton fabrics. ${ }^{54}$ With the increases in mechanization in textile production in the $1780 \mathrm{~s}$, Manchester's manufacturers required a fiber long enough and resistant enough not to break during cotton spinning. ${ }^{55}$ For example, the records of the weaving business Cardwell, Birley, and Hornby in Manchester show that they were buying cotton from Maranhão in the 1790s. ${ }^{56}$ As for the West Indies, contemporary accounts from the late eighteenth century indicate that the islands supplied raw cotton used to manufacture items of lower quality, while the northern parts of South America supplied raw material for finer and lighter fabrics. ${ }^{57}$

The quality of West Indies raw cotton, despite being superior to Smyrna's, was an increasing concern in the 1780 s due to its weak fiber resistance. ${ }^{58}$ Cotton manufacturers from Manchester expressed concern over the quality of cotton from the West Indies in 1787: in a document to the Lords Committee of Privy Council for Trade, a spokesman for the industrialists wrote that, while it was "extremely desirous" that the government promoted the cultivation of cotton in British dominions "in order to prevent the great importations from other foreign powers," the West Indies did not usually cultivate the finest cottons. The finest cottons near the

\footnotetext{
52 John H. Coatsworth, "American Trade with European Colonies in the Caribbean and South America, 17901812," The William and Mary Quarterly 24, no. 2 (April 1967): 243, doi:10.2307/1920838.

${ }^{53}$ Ellison, The Cotton Trade of Great Britain, 22; Bryan Edwards, The History, Civil and Commercial, of the British West Indies, 5th ed., vol. 2 (London: G. and W.B. Whittaker, 1819), 316.

${ }^{54}$ Edward Baines, History of the Cotton Manufacture in Great Britain (R. Fisher and P. Jackson, 1835), 311.

${ }^{55}$ David Macpherson and Adam Anderson, Annals of Commerce, Manufactures, Fisheries, and Navigation, with Brief Notices of the Arts and Sciences Connected with Them., vol. 4, 4 vols. (London: Nichols, 1805). 56 "The Records of Cardwell, Birley and Hornby" (Manchester, 1792 1768), Ms. 1199., The John Rylands Library.

${ }^{57}$ Smithers, Liverpool, Its Commerce, Statistics, and Institutions, 123.

${ }^{58}$ Edwards, The History, Civil and Commercial, of the British West Indies, 2:317.
} 
Caribbean were grown in Cayenne and Tobago - "the former is very near the continent of South America and the latter much inferior in quality to Siam or Brazil." 59

Given the different species used in textile production after 1781, most staples characterized as "superior" were derived from the species G. barbadense, which was indigenous to South America. ${ }^{60}$ One important advantage of the barbadense was its weak fibre attachment to the seed, which did not require the saw-gin technology later used on the "fuzzyseed" cotton cultivated in the United States. Before the widespread use of saw-gins, descriptions of different species stated that the wool in the green-seed cotton was so firmly attached to the seed that it was not profitable to have it prepared for the market. If this problem were solved (which eventually happened), green-seed cotton would "doubtless be a valuable acquisition to the muslins manufactory."

A 1798 description of different seeds grown in Brazil provides evidence that planters knew about the green-seed cotton (G. hirsutum), which produced a "strong yarn," enabling the production of "delicate" fabrics. ${ }^{62}$ The most important cotton staple was known as "Maranhão cotton," (which, surprisingly, was cultivated more in Pernambuco), which produced a longer staple and could be prepared by hand or simple roller gins. ${ }^{63}$ As international seed exchange seemed to be fairly common, with cotton plants developing a range of characteristics in different regions, the "Maranhão" cotton may have been the source of the U.S. Sea Island cotton. A record from 1789 contains a request from planters in Georgia to be allowed to cultivate "Pernambuco cotton seeds" on nearby islands. ${ }^{64}$ The possible link between Pernambuco cotton and Sea Island is reinforced by records of Brazilian planters from the beginning of the nineteenth century stating that these staples had similar buyers in British

\footnotetext{
59 “The National Archive of the UK BT 6/140” 1792 1787, fol. 35, The National Archives, Kew.

${ }^{60}$ Lakwete, Inventing the Cotton Gin.

${ }^{61}$ Bryan Edwards, Arthur Broughton, and William Young, The History, Civil and Commercial, of the British Colonies in the West Indies. By Bryan Edwards, Esq. F.R.S. S.A. In Three Volumes., vol. 2 (London: Printed for John Stockdale, Piccadilly, 1801), 310.

62 José de Sá Bettencourt, Memoria sobre a plantação dos algodões, : e sua exportação; sobre a decadencia de lavoura de mandiocas, no termo da villa de Camamú, comarca dos Ilhéos, governo da Bahia, appresentada, e offerecida a sua alteza real o Principe do Brazil nosso senhor, ([Lisbon] : Na officina de Simão Thaddeo Ferreira., 1798), 29-33.

63 "Maranhão cotton," Gossypium de Lin (also barbadense), see Manuel Arruda da Camara, Memoria Sobre a Cultura Dos Algodoeiros E Sobre O Methodo de O Escolher, E Ensacar (Lisboa: Officina da Casa Litteraria, 1799), 29; John Forbes Royle, On the Culture and Commerce of Cotton in India and Elsewhere; with an Account of the Experiments Made by the Hon. East India Company up to the Present Time (London: Smith, Elder, 1851), 151.

${ }^{64}$ Donnell, Chronological and Statistical History of Cotton., 48.
} 
markets. ${ }^{65}$ The best samples were also used for high-end markets, such as lace in the case of Sea Island cotton and hosiery for Pernambuco cotton. ${ }^{66}$

Various sources attest to the high quality of Brazilian cotton at the end of the eighteenth century. ${ }^{67}$ Manchester cotton manufacturers classified raw cotton based on their "general estimation" of the market. The most esteemed cotton was the one from Malacca and the Kingdom of Siam; the second came from Brazil, such as Pernambuco and Maranhão and the third most favored type was from Demerara, Surinam and Cayenne. The cotton that occupied the lowest position in the Manchester manufacturers' evaluation was the one from the West Indies. ${ }^{68}$ A source from France in 1774 also graded different staples, classifying West Indian cotton in three grades: Cayenne (which had a small production), San Domingo, and Guadeloupe. According to that source, despite Cayenne's higher quality, the "superiority of Brazilian cotton over all others had been recognized" around the end of the 1770s. ${ }^{69}$ In his 1799 work entitled "A memoir about the culture of cotton," the Portuguese author Manuel Câmara wrote that cotton from Maranhão, which grew a bigger bush than the ordinary cotton plant, was regarded as a superior kind..$^{70}$ For Câmara, the "stiffer and longer fiber" characterized the quality of Maranhão’s most common cotton plant. ${ }^{71}$

Brazilian cotton maintained its prestigious position even when new suppliers entered the market. James Butterworth in the 1820s attributed a lower commercial value to the three main types of cotton from the United States - Bowed Georgia, Tennessee, and New Orleans. ${ }^{72}$ According to the author, inferior textiles used these staples and they could not compete with the quality of cotton from Pernambuco. Among the 35 best-known cotton suppliers, Butterworth listed the varieties with higher commercial value, in the following decreasing

\footnotetext{
${ }^{65}$ Raimundo José de Souza Gayoso, Compendio Historico-Politico Dos Principios Da Lavoura Do Maranhão (Paris: Officina de P.-N. Rougeron, 1818), 266.

${ }^{66}$ Abraham Rees, "Cotton," in The Cyclopadia; Or, Universal Dictionary of Arts, Sciences, and Literature (London: Longman, Hurst, Rees, Orme \& Brown, 1819).

${ }^{67}$ For an early typology of cotton varieties, see Roland de La Platiere, Encyclopédie méthodique: Manufactures, arts et métiers (Paris: Panckoucke libraire, 1785), 214.

68 "The National Archive of the UK BT 6/140," fol. 34.

${ }^{69}$ Wadsworth and Mann, The Cotton Trade and Industrial Lancashire, 1600-1780, 185.

${ }^{70}$ Camara, Memoria Sobre a Cultura Dos Algodoeiros E Sobre O Methodo de O Escolher, E Ensacar, 15.

${ }^{71}$ Dias, A Companhia Geral do Grão Pará e Maranhão (1755-1778)., 372; Mesquita, Vida e morte da economia algodoeira do Maranhão.

72 James Butterworth, A Complete History of the Cotton Trade: Including Also, that of the Silk, Calico-Printing, \& Hat Manufactories; with Remarks on Their Progress in Bolton, Bury, Stockport, Blackburn, and Wigan, to Which Is Added, an Account of the Chief Mart of These Goods, the Town of Manchester (Manchester: C.W. Leake, 1823), 51. Georgia was the most common as early as 1795 , but its resulting fabric was considered "not wholly satisfactory," G. W. Daniels, "American Cotton Trade with Liverpool Under the Embargo and Non-Intercourse Acts," The American Historical Review 21, no. 2 (January 1, 1916): 276, doi:10.2307/1835050.
} 
order: Sea Island Georgia, Bourbon (East Indies), Pernambuco, Cayenne (Suriname), Bahia and Maranhão. In 1822, Antônio Pereira do Lago also stated that European markets preferred Pernambuco's cotton to Maranhão's, although the latter was superior to the ones from Guadalupe and San Domingue. ${ }^{73}$

The quality of Pernambuco cotton is also mentioned by merchants: in a letter to England dated 1808, Guilherme Warren, a merchant in Rio de Janeiro, wrote that Pernambuco cotton was much esteemed in British markets, and had a quality comparable to cotton produced in the United States, and that other Brazilian regions could easily expand their production to meet the growing demand for cotton in Europe. ${ }^{74}$ The second document, by Roger Hunt, from London, stated that prior to 1800 Pernambuco cotton was estimated in Britain "chiefly for the fineness and silkiness of its staple." ${ }^{75}$ Such qualitative evidence is consistent with differences in prices in British markets. Figure 2.2 shows that Pernambuco's cotton received on average higher prices than Georgia, and the cotton produced in Suriname and Demerara, which were among the staples with the highest quality in the West Indies.

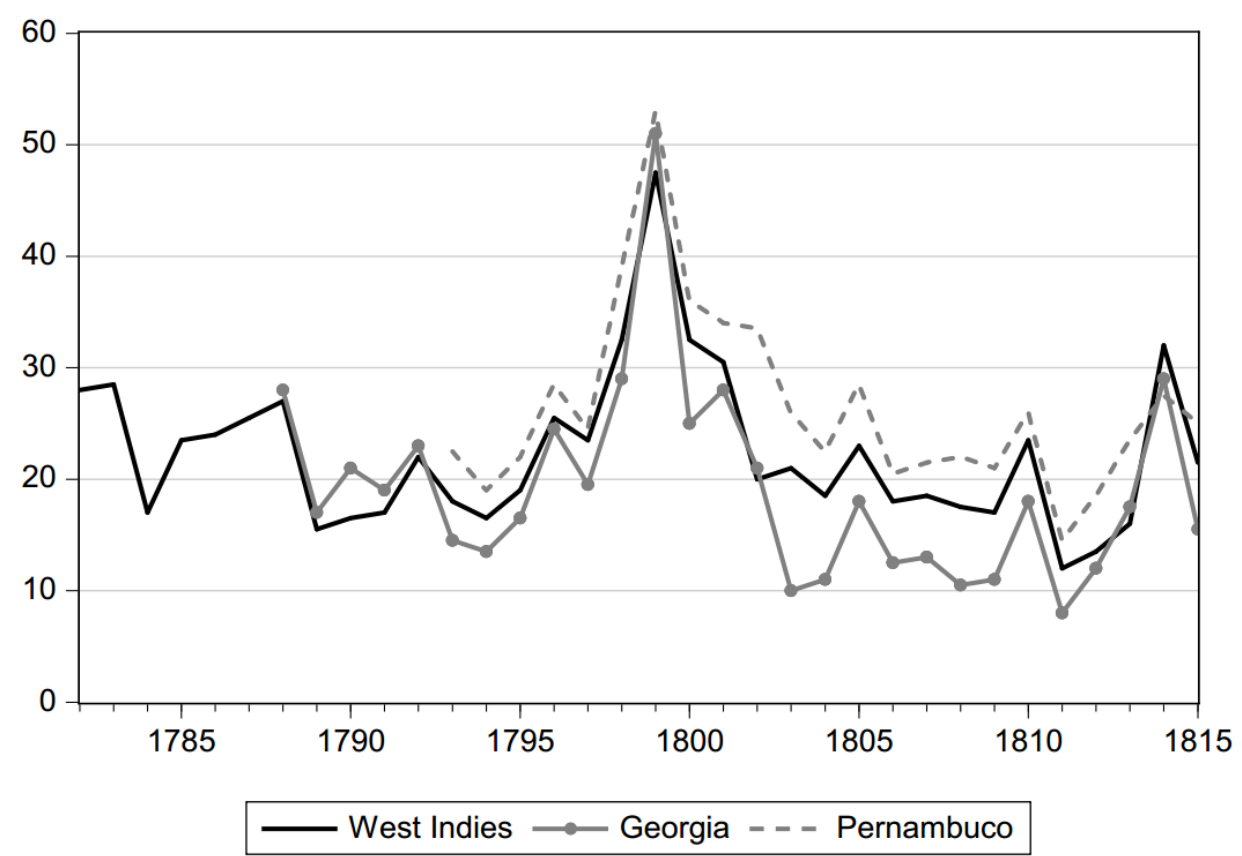

Figure 2.2 - Average prices of cotton in Britain, 1782-1815 (pence/lb)

Source: Thomas Tooke, A History of Prices, Vol. V

\footnotetext{
${ }^{73}$ Lago, Estatística histórico-geográfica da província do Maranhão, 42. The same argument was made by Gayoso, a cotton planter in Maranhão, in 1813. Gayoso, Compendio Historico-Politico Dos Principios Da Lavoura Do Maranhão.

${ }^{74}$ José Jobson de Andrade Arruda, Uma colonnia entre dois impérios: a abertura dos portos brasileiros 1800-1808 (Cátedra Jaime Cortesão, 2008), 157.

${ }^{75}$ Roger Hunt, Observations upon Brazil Cotton Wool ... with a View to Its Improvement (London: Steel, Printer, 1808), 3.
} 
The commercial value of cotton varied according to the difference in the resistance and length of staple, given that spinning machines required a fiber that would not break easily and halt production. Shorter fibers were also more difficult to spin and resulted in a coarser product. ${ }^{76}$ The way to measure the quality of textiles was through mass density - spinning count classified fabric fineness - and the metric was the number of hanks of yarn spun from a pound of wool. ${ }^{77}$ More rudimentary machinery, such as the spinning jenny, could not produce high count yarns at a competitive price. ${ }^{78}$ The first technological improvement that raised productivity in calicoes was the water frame, which had been employed in the manufacture of products with counts up to 60 . After 1779 , Crompton's mule combined elements from older spinning machines and the water frame and increased productivity of finer fabrics. Whereas there were still more water frame spindles than mules in use in the 1780s, the mule progressively replaced the water frame in the following decade, due to its superior technology. ${ }^{79}$

Aside from making it possible to manufacture yarns finer than those made on water frames, Crompton's invention significantly reduced production costs: compared to the cost of manual processes from three decades earlier, the mule turned out finer yarns at one-twentieth of the price of $1749 .^{80}$ As Table 2.3 shows, yarns with higher counts also represented higher profits and, therefore, the mule allowed the market for cotton textiles to progressively move away from coarser products. ${ }^{81}$ The significant decrease in production costs for high-count cotton textiles made the British industry competitive versus Indian production of calicoes and eventually even versus fine Bengal muslins. ${ }^{82}$

Table 2.3 - Cotton spinning costs using Crompton's mule, 1779

\begin{tabular}{ccccc}
\hline $\begin{array}{c}\text { Count } \\
\text { (hanks) }\end{array}$ & $\begin{array}{c}\text { Cost of spinning } \\
\text { (a) }\end{array}$ & $\begin{array}{c}\text { Raw Material, } \\
18 \text { ounces (b) }\end{array}$ & $\begin{array}{c}\text { Total Market } \\
\text { Value (c) }\end{array}$ & $\begin{array}{c}\text { Profit } \\
{[\mathrm{c}-(\mathrm{a}+\mathrm{b})]}\end{array}$ \\
\hline 40 & $14 \mathrm{~s} .0 \mathrm{~d}$. & $3 \mathrm{~s} .3 \mathrm{~d}$. & $20 \mathrm{~s} .9 \mathrm{~d}$. & $3 \mathrm{~s} .6 \mathrm{~d}$. \\
60 & $25 \mathrm{~s} .0 \mathrm{~d}$. & $3 \mathrm{~s} .3 \mathrm{~d}$. & $34 \mathrm{~s} .0 \mathrm{~d}$. & $5 \mathrm{~s} .9 \mathrm{~d}$. \\
80 & $42 \mathrm{~s} .0 \mathrm{~d}$. & $3 \mathrm{~s} .3 \mathrm{~d}$. & $54 \mathrm{~s} .3 \mathrm{~d}$. & 9s. 0d. \\
\hline
\end{tabular}

Source: James A. Mann, The Cotton Trade of Great Britain, 27

\footnotetext{
76 Thomas Woodhouse, Yarn Counts and Calculations (H. Frowde and Hodder \& Stoughton, 1921).

77 C. P. Brooks, Cotton Manufacturing, 3rd ed. (London: Blackburn, 1892).

${ }^{78}$ Allen, The British Industrial Revolution in Global Perspective, 184.

${ }^{79}$ Stanley D. Chapman, The Cotton Industry in the Industrial Revolution (London: Macmillan, 1972), 29.

${ }^{80}$ James A. Mann, The Cotton Trade of Great Britain: Its Rise, Progress and Present Extent (Simpkin, Marshall, 1860).

${ }^{81}$ Harley, "Cotton Textile Prices and the Industrial Revolution," 50.

${ }^{82}$ Chapman, "Quantity Versus Quality in the British Industrial Revolution"; Edwards, The Growth of the British Cotton Trade, 1780-1815, 39.
} 
In 1788, with new markets in sight, Manchester producers - who already represented an important pressure group - lobbied the government for protection against foreign muslins. ${ }^{83}$ In a document titled "An Important Crisis in the Cotton Manufactory of Great Britain Explained," Manchester industrialists argued that the infant industry already employed a considerable number of people and high count textiles generated more income for the United Kingdom economy than lower quality fabrics. ${ }^{84}$ The document presents the distribution of different cotton staples according to different products, showing that Brazil was not competing with previous cotton suppliers because cottons from Turkey and the West Indies were used in lower count products: calicoes were made with yarn between 20 and 40 count on average, while muslins used counts above $40 . .^{85}$ Of the $19,828,805$ pounds of raw cotton imported in 1787 , a staggering 18,670,000 pounds was used in the cotton manufacturing industry. ${ }^{86}$ The raw material was divided into four large groups: 1) 1,500,000 pounds used for hosiery; 2) 1,670,000 pounds for silk and linen mixtures; 3) 5,000,000 in making fustians; 4) 10,500,000 went to make all types of muslins and calicoes (shawls, handkerchiefs, etc.). Based on this classification, Table 2.4 presents the Manchester cotton production broken down according to class - from the coarsest to the finest quality.

Table 2.4 - Cotton manufacture in the United Kingdom, 1788

\begin{tabular}{lcc}
\hline Type of Cotton & Quantity & Hanks in the pound* \\
\hline Smyrna; Coarse India; Inferior West India & $5,330,000$ & 8 to 16 \\
British Islands (except Barbados, & $3,700,000$ & 17 to 20 \\
Guadaloupe, and Martinique) & & \\
Barbados, Tobago, St. Domingue & $5,050,000$ & 21 to 28 \\
Inferior Dutch and Brazil & $1,500,000$ & 29 to 40 \\
Very Good Dutch and Brazil & $2,000,000$ & 41 to 70 \\
Finest Brazil and East India & $1,090,000$ & 71 to 150 \\
\hline
\end{tabular}

Source: "An Important Crisis in the Cotton Manufactory of Great Britain explained" (BNA BT 6/140). * A hank is 840 yards long.

The economic importance of fine textiles is evident when their revenue is compared with those generated by coarse fabrics. Even after reporting that the prices of the finest wool had fallen by 40 percent, the production of 1,090,000 pounds generated $£ 756,187$. Since East India cotton totaled 90,000 pounds, approximately $1,000,000$ pounds of high-quality cotton came from Brazil. The hosiery branch accounted for most counts above 100, and additional

\footnotetext{
${ }^{83}$ O’Brien, Griffiths, and Hunt, "Political Components of the Industrial Revolution," 396.

84 "The National Archive of the UK BT 6/140."

${ }^{85}$ Harley, "Cotton Textile Prices and the Industrial Revolution," 58.

${ }^{86}$ The difference was to candle wick production.
} 
sources show that cotton from Pernambuco was extensively used in that branch. ${ }^{87}$ Unlike the revenue from branches that used high-quality staples, the revenue from the Smyrna cotton products branch was only $£ 536,172$. Given the market value of fine cotton textiles, manufacturers stated that muslins should be extensively promoted because they returned "more for the labor of the people than any other article in the cotton manufactory." 88

The increase in Brazilian exports during the 1780s was clearly due to the high quality of the products, as cotton from Brazil does not appear in products with counts bellow 29. Even if the count numbers are inflated - after all, it was a document to be used for lobbying purposes - the evidence suggests that cotton from Brazil was in a different league from that of cotton from former suppliers such as the West Indies. Moreover, Smyrna cotton, which had been the most important staple produced outside British dominions, was only used with very low counts. Therefore, the decline of Turkey's cotton exports was not a result of "better access to labor" in Brazil compared to the Ottoman Empire, as Sven Beckert argues. ${ }^{89}$ In the late 1780s, the average count for cotton fabrics in British factories was 27, higher than what Turkey and most British islands could produce. ${ }^{90}$ Market segmentation among different cotton staples explains why British sources would have inevitably moved away from the Caribbean anyway, even if the violent political conflicts in the 1790s had not occurred. Cotton plantations were moving from islands to continental areas where cultivation of better staples was possible.

Nevertheless, continuous technological improvements ended up eliminating the competitive advantage enjoyed by Brazilian fiber in the early days of spinning. During the 1810 s, processes that mixed shorter staples with longer ones made it possible for manufactures to substitute the mixture for more expensive cotton, reducing the price premium for Brazilian staples. ${ }^{91}$ Upland cotton mixes with Egyptian or Pernambuco cotton could be spun into numbers higher than 50. ${ }^{92}$ Moreover, the increased use of mules after 1800 made it easier to use mixed staples, as the mule subjected the cotton fiber to less strain than previous machines and, therefore, could spin higher counts even with "inconsistent" cotton. ${ }^{93}$

\footnotetext{
${ }^{87}$ Rees, "Cotton."

88 "The National Archive of the UK BT 6/140."

${ }^{89}$ Beckert, Empire of Cotton.

${ }^{90}$ Allen, The British Industrial Revolution in Global Perspective, 187; George Richardson Porter, The Progress of the Nation (London: C. Knight \& Co., 1836), 213.

${ }^{91}$ Baines, History of the Cotton Manufacture in Great Britain, 311; Donnell, Chronological and Statistical History of Cotton., 68.

92 Royle, On the Culture and Commerce of Cotton in India and Elsewhere, 129.

${ }^{93}$ William Lazonick, "Factor Costs and the Diffusion of Ring Spinning in Britain Prior to World War I," The Quarterly Journal of Economics 96, no. 1 (1981): 95, doi:10.2307/2936142.
} 


\subsection{Portugal and the beginning of cotton production in Brazil}

The increase in cotton exports from Brazil after 1780 represented an important change in Portugal's trade patterns in the eighteenth century. Before Brazilian cotton became Portugal's main export to Britain, wine dominated foreign sales and accounted for almost three quarters of British wine consumption around $1760 .{ }^{94}$ In 1772, exports from Portugal to Great Britain amounted to $£ 671,318$, of which $£ 474,447$ derived from wine. The city of Porto produced the wine that accounted for half the Portuguese wine trade, and this increased to 60 percent in 1785. ${ }^{95}$ The predominance of port wine in British markets was a result of the Methuen Treaty (1703), which established that duties levied on Portuguese wine could not amount to more than a third of duties levied on French wines. ${ }^{96}$

The Methuen Treaty, in turn, largely benefited the British textile industry and the commercial privileges accorded to foreigners caused resentment in Portugal. ${ }^{97}$ But the decline of gold and diamond production in Brazil that set in in the 1750s led to changes in Portugal's trade policy with Britain. ${ }^{98}$ During the 1760 s, the founding of the Douro Company led to complaints by British merchants because it limited foreign participation in the wine trade. ${ }^{99}$ Policies implemented by Pombal, the de facto ruler of Portugal between 1750s and 1770s, and a well-known critic of Anglo-Portuguese commercial relations, also prohibited British merchants from negotiating directly with the colonies. Trade restrictions with Brazil were imposed through the creation of two trade monopoly companies: the Company of Grão Pará and Maranhão, established in 1755, and the Company of Pernambuco and Paraíba, founded a year later. These companies limited the trade of commodities to Portuguese vessels and created the conditions for large-scale plantations by promoting imports of slave labor from Portuguese colonial ports in Africa. ${ }^{100}$ Moreover, in 1756, the new governor of Maranhão, Pombal's

\footnotetext{
${ }^{94}$ Harold E. S. Fisher, The Portugal Trade: A Study of Anglo-Portuguese Commerce, 1700-1770 (London: Methuen, 1971).

95 "The National Archive of the UK BT 6/63" 1791 1770, The National Archives, Kew.

${ }^{96}$ For a detailed description of the treaty, see: Leonor Freire Costa, José Luís Cardoso, and Nuno Gonçalo Monteiro, O Tratado de Methuen (1703) - Diplomacia, Guerra, Política e Economia, ed. Livros Horizonte (Lisboa: Livros Horizonte, 2003).

97 John Ehrman, The British Government and Commercial Negotiations with Europe 1783-1793 (Cambridge University Press, 2013), 9.

98 Boxer, The Portuguese Seaborne Empire, 1415-1825, 181; Kenneth Maxwell, Pombal, Paradox of the Enlightenment (CUP Archive, 1995), 60.

99 Alan David Francis, Portugal 1715-1808: Joanine, Pombaline and Rococo Portugal as Seen by British Diplomats and Traders (Tamesis, 1985), 173.

${ }^{100}$ António Carreira, A companhia geral do Grao-Para e Maranhao: o comercio monopolista, Portugal-AfricaBrasil na segunda metade do seculo XVIII. (Companhia editora nacional, 1988).
} 
brother, repealed a 1703 law that prohibited cotton exports. ${ }^{101}$ The end of prohibition would eventually enable cotton to become a key part of the "agricultural renaissance" in Brazil during the last quarter of the eighteenth century. ${ }^{102}$ With the increase in trade, annual slave imports in Maranhão tripled between 1783 and 1808, while in other northeastern regions the annual average of arrivals remained stable. ${ }^{103}$ In the first census of Maranhão in 1798, slaves represented half the population. ${ }^{104}$

The reason behind the incentive to grow cotton in Maranhão was that Pombal wanted to promote textile production in Portugal. ${ }^{105}$ The Methuen Treaty was initially an impediment to developing a domestic textile sector as it stopped Portugal from raising tariff barriers to favor local production. But as the treaty with Britain was restricted to woolen textiles, the increasing use of cotton to produce fabrics provided a loophole for stimulating textile production in Portugal without direct diplomatic confrontation. ${ }^{106}$ Thus, by relying on the Brazilian trade companies to transport the raw materials, cotton enterprises began to develop in Portugal during the 1770s. ${ }^{107}$ Moreover, data on the list of ships that entered the port of Lisbon as provided by two British consuls - W. H. Lyttleton in 1769 and Robert Walpole in 1774 - show that Maranhão was the only colonial region that exported cotton to Portugal at the time. ${ }^{108}$ However, British merchants in Portugal began to react against being excluded from trading, complaining against the "destructive tendency of the exclusive companies," which set off a diplomatic conflict between the two nations. ${ }^{109}$ After reaching its export peak of $£ 1.3$ million during the 1750s, between 1765 and 1785, British trade with Portugal declined to $£ 600,000 .{ }^{110}$

\footnotetext{
101 John Branner, Cotton in the Empire of Brazil ; the Antiquity, Methods and Extent of Its Cultivation, Together with Statistics of Exportation and Home Consumption (U.S. Department of Agriculture, 1885), 17.

${ }^{102}$ Alden, "Late Colonial Brazil, 1750-1808," 310. Luiz Felipe Alencastro, O Trato dos Viventes (São Paulo, Brazil: Companhia das Letras, 2000), 142.

103 “The Trans-Atlantic Slave Trade Database,” Voyages Database, accessed January 5, 2015, http://www.slavevoyages.org/.

104 “'OFÍCIO Do Governador E Capitão Do Maranhão E Piauí, D. Diogo de Sousa Para O Secretário de Estado Da Marinha E Ultramar, D. Rodrigo de Sousa Coutinho" (São Luís do Maranhão, Abril 1799), AHU_CU_009, Cx. 104, D. 8313, Arquivo Histórico Ultramarino.

${ }^{105}$ Jorge M. Pedreira, "From Growth to Collapse: Portugal, Brazil, and the Breakdown of the Old Colonial System (1760-1830)," Hispanic American Historical Review 80, no. 4 (November 1, 2000): 839-64, doi:10.1215/00182168-80-4-839; Dias, A Companhia Geral do Grão Pará e Maranhão (1755-1778)., 373.

${ }^{106}$ For the relation between the treaty and the "wool interest," see Paul Duguid, "The Making of Methuen: The Commercial Treaty in the English Imagination," Revista Da Faculdade de Letras História, III, 4 (2003): 28.

${ }^{107}$ Kenneth Maxwell, Conflicts and Conspiracies: Brazil and Portugal, 1750-1808 (Routledge, 2004), 45.

108" "States of Navigation, Commerce and Revenue."

109 "The Memorial of Francis Ibbetson," The Caledonian Mercury, September 23, 1767, 7048 edition, The British Newspaper Archive.

${ }^{110}$ Portugal, Trade with Great Britain, "The National Archive of the UK BT 6/63."
} 
Trade records from the 1760s and 1770s, therefore, provide evidence that when Britain increased its demand for cotton in the 1780s, Brazilian cotton plantations had already existed for two decades. At the same time, during these two decades there was no resolution to the commercial dispute in the wine sector. Diplomatic conflict with Portugal continued with the end of Anglo-French wars in 1783, when the British government sought to strengthen ties with France through a new commercial treaty. In their negotiations on the trade agreement, France requested a most-favored-nation status for their wines, which would give them parity with Portuguese wines and, therefore, violate the Methuen Treaty. ${ }^{111}$ Yet the incentive not to terminate the treaty with Portugal was that woolen fabrics could enter the country free of duty. By way of compromise, the Treaty of Navigation and Commerce (Eden Treaty), signed in Paris, gave Britain the future possibility to lower duties on Portuguese wines in accordance with the Methuen Treaty. ${ }^{112}$ London newspapers reported the conflict and, according to The Times, the "spirit of Methuen" had to be preserved because Portugal was Britain's "best ally."113 The newspaper also reported complaints from the Portuguese council in London that the new treaty harmed merchants trading with Spain and Portugal. ${ }^{114}$

The conflict between Portuguese and French wine indirectly involved Brazilian cotton, too, a fact that came up in several public discussions. In a debate in the House of Lords in February $28^{\text {th }}, 1787$, the Duke of Norfolk spoke presented a defense against the violation of the Methuen Treaty, arguing that "the very existence of the leading branch of our manufactures depended on the importation of the cotton wool of Brazil, which we could only have through the medium of Portugal, which our pretend friends at this very minute were endeavoring to deprive us of." 115 The Duke of Norfolk's accusation was that France, the "pretend friend," was trying to benefit from Portuguese resentment at the Eden Treaty conditions. According to Walpole and Fawkener, who were British envoys in Lisbon at the time, in 1786, Portugal was induced to accept a commercial agreement under which France would buy all cotton crops from Brazil. ${ }^{116}$

\footnotetext{
${ }^{111}$ Charles Ludington, The Politics of Wine in Britain: A New Cultural History (Palgrave Macmillan, 2013$), 167$. 112 "The Following Is an Authentic ABSTRACT of the TREATY of NAVIGATION and COMMERCE, Signed at Paris on the 26th Ult..," The Times, October 5, 1786, 547 edition, The Times Digital Archive 1785-2006 (Gale). 113 “Universal Register..," The Times, October 20, 1786, 560 edition, 2, The Times Digital Archive 1785-2006 (Gale).

114 "Mr. Eden Has Been More Negligent, and Less Informed, in the Affair of the Commercial Treaty,.." The Times, December 7, 1786, 565 edition, The Times Digital Archive 1785-2006 (Gale).

115 "House of Lords..," The Times, March 1, 1787, 688 edition, 2, The Times Digital Archive 1785-2006 (Gale).

${ }^{116}$ Ehrman, The British Government and Commercial Negotiations with Europe 1783-1793, 73.
} 
The slow growth of the wine trade gave Portugal an additional incentive to use raw cotton to enhance its trade position with Britain. In 1788, on the death of Dom José, "Prince of Brazils," British newspapers reported concerns about the future of trade with Portugal because "the importation of Brazil cotton, and the wines of Portugal into Great Britain, constitute a very principal part of their commerce." 117 While Portugal continued to delay its answer to British diplomatic demands, their trade position began to improve and, in 1790, "for the first time in the century, bullion had to be exported to Lisbon." 118 Change happened not only by means of a reduction in imports, but also because Brazilian cotton was important to create a more balanced commerce with Britain. ${ }^{119}$ Much of this transformation in trade relations occurred in the $1780 \mathrm{~s}$, during which time British imports of Brazilian cotton increased almost sevenfold.

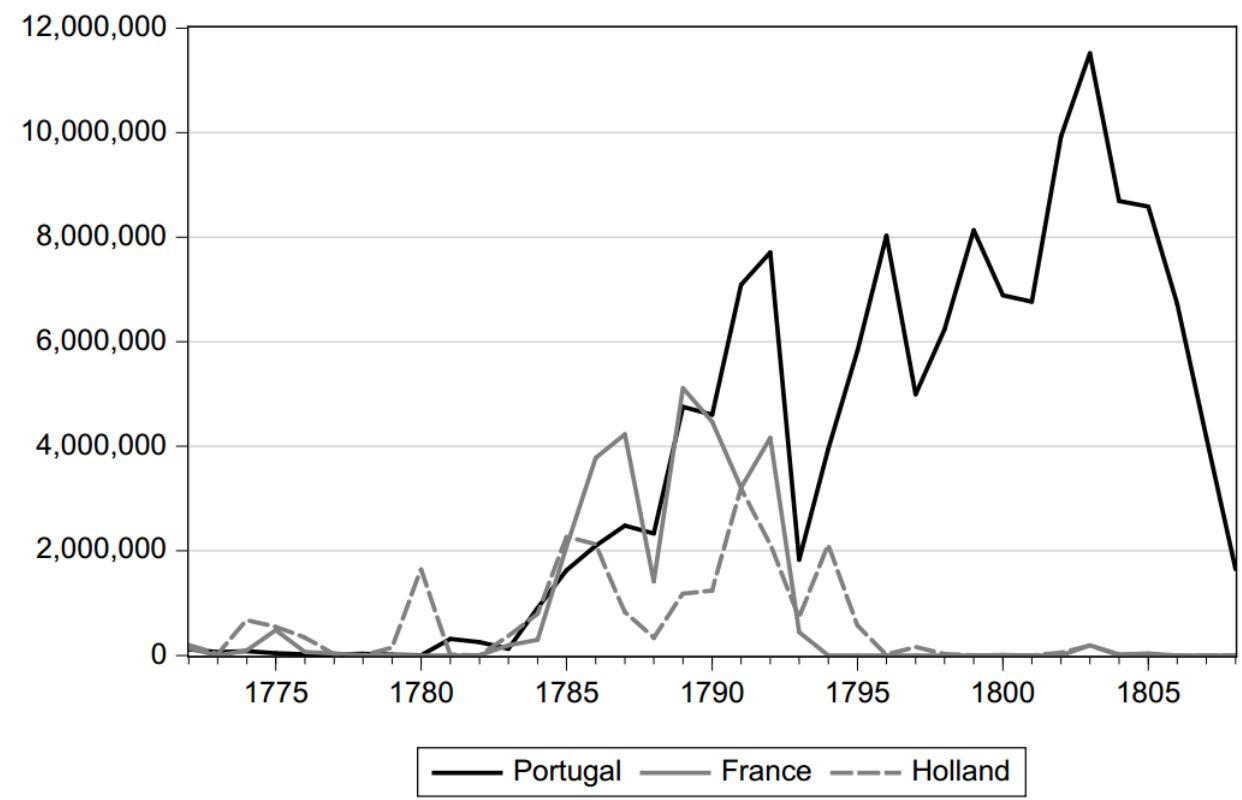

Figure 2.3 - Raw Cotton Imports in England, 1772-1808 (pounds weight) Source: 1772-1807 State of Navigation, Commerce and Revenue (BNA CUST 17)

Figure 2.3 shows that the period of political stability after the Treaty of Paris (1783) coincides with the rise of Brazilian cotton exports. At first, higher demand for raw cotton benefited other European Empires that had possessions in the Americas, but after the declaration of war with France in 1793, important suppliers from the Caribbean faced a steep decline in their production. The continuous warfare between France and Britain between 1793 and 1815 had a dramatic impact on trade in Europe. ${ }^{120}$ And yet, from the 1790s until Napoleon's

\footnotetext{
117 "Portugal..," The Times, September 30, 1788, 1132 edition, 2, The Times Digital Archive 1785-2006 (Gale).

${ }^{118}$ Ehrman, The British Government and Commercial Negotiations with Europe 1783-1793, 151.

${ }^{119}$ Maxwell, Conflicts and Conspiracies, 50.

${ }^{120}$ Kevin H O'Rourke, "The Worldwide Economic Impact of the French Revolutionary and Napoleonic Wars, 1793-1815," Journal of Global History 1, no. 01 (2006): 123-149. Martin Robson, Britain, Portugal and South
} 
invasion of Portugal at the end of 1807, Brazil's cotton continued to increase its share in British markets. The conflict with France created several concerns for the British government, one of which was trade with Brazil. In a motion on the state of public affairs regarding the destination of fleets to protect British interests, launched in the House of Commons in 1805, Brazil was considered a key location. After Jamaica, Brazil was "the most probable" destination of the fleets and "one every way of vast importance." Brazil's importance was not restricted to Rio de Janeiro's position as a military warehouse in the British India trade route, but also because of the consequences on Brazilian trade resulting from a possible French attack on the Brazilian coast: if the enemy controlled the coast, it would deprive the British textile sector of Brazilian cotton, which was "essential in our manufactures." 121

Table 2.5 - Trade between the port of Lisbon and British dominions

\begin{tabular}{|c|c|c|c|c|c|}
\hline & $\begin{array}{c}\text { Produce of } \\
\text { Portugal }\end{array}$ & $\begin{array}{c}\text { Produce of } \\
\text { Brazil }\end{array}$ & $\begin{array}{c}\text { Produce of } \\
\text { Asia }\end{array}$ & $\begin{array}{l}\text { Total Goods } \\
\text { Exported to UK }\end{array}$ & $\begin{array}{c}\text { Brazilian } \\
\text { Cotton (\%) }\end{array}$ \\
\hline \multicolumn{6}{|c|}{ From the British Board of Trade (£) } \\
\hline 1786 & 169,533 & 213,054 & 292,289 & 679,286 & 26.6 \\
\hline 1789 & 123,219 & 273,066 & 0 & 396,380 & 62.4 \\
\hline 1790 & 155,045 & 357,930 & 5,638 & 518,618 & 65.5 \\
\hline 1792 & 171,687 & 686,842 & 4,598 & 865,732 & 74.1 \\
\hline \multicolumn{6}{|c|}{ From the Portuguese Balance of Trade $(£)^{*}$} \\
\hline 1796-99 & 179,198 & 728,401 & 1,152 & 911,563 & 77.3 \\
\hline $1800-02$ & 134,347 & 845,051 & 768 & 982,712 & 80.9 \\
\hline $1803-05$ & 145,554 & 857,134 & 690 & $1,004,473$ & 75.1 \\
\hline 1806-09 & 208,313 & 441,189 & 1,804 & 660,442 & 54.5 \\
\hline
\end{tabular}

Source: Board of Trade, Portugal: Trade with Great Britain (BNA BT 6/63). Portuguese Balance of Trade. * No data for 1798 and 1808.

Between 1796 and 1806, commodities from Brazil represented 40 percent of Portuguese exports to England. Since production from within the Portuguese Kingdom accounted for 50 percent of trade with England, commerce from other parts of the Portuguese empire was marginal. ${ }^{122}$ Britain received a considerable volume of products from the city of Porto, but colonial products were overwhelmingly exported through the port of Lisbon. In 1786, whereas Lisbon exported 1,800,360 pounds of cotton to Britain, Porto exported only 6.5 percent of that amount. Table 2.5 shows that during the last years of the eighteenth century, cotton represented around three quarters of trade with Britain through the "colonial" port of Lisbon. Cotton

America in the Napoleonic Wars: Alliances and Diplomacy in Economic Maritime Conflict (London: I. B. Tauris, 2011).

121 "State of Public Affaire, Commons Sitting" (London, June 20, 1805), Hansard, http://hansard.millbanksystems.com/.

122 Jorge Borges de Macedo, O bloqueio continental: economia e guerra peninsular (Gradiva, 1990), 56. 
represented more than 90 percent of the value of Brazilian exports that were destined for the United Kingdom in the 1790s.

\subsection{West Indies cotton}

The literature singles out the decline of cotton exports in foreign possessions in the Caribbean during the 1790s as the main reason why Brazil became a major cotton supplier to Britain in the late eighteenth century. Although it is true that exports from the British West Indies were negatively affected by the Saint Domingue revolt in 1791 and declarations of war with France and Holland, this section presents evidence that even with a decline in cotton imports from older possessions in the West Indies, newly-conquered territories allowed for the continued growth of cotton supply. Figure 2.4 shows that political instabilities favored Britain's interests in the region enabling Britain to make a series of territorial conquests, especially with respect to the former Dutch colony of Demerara in South America.

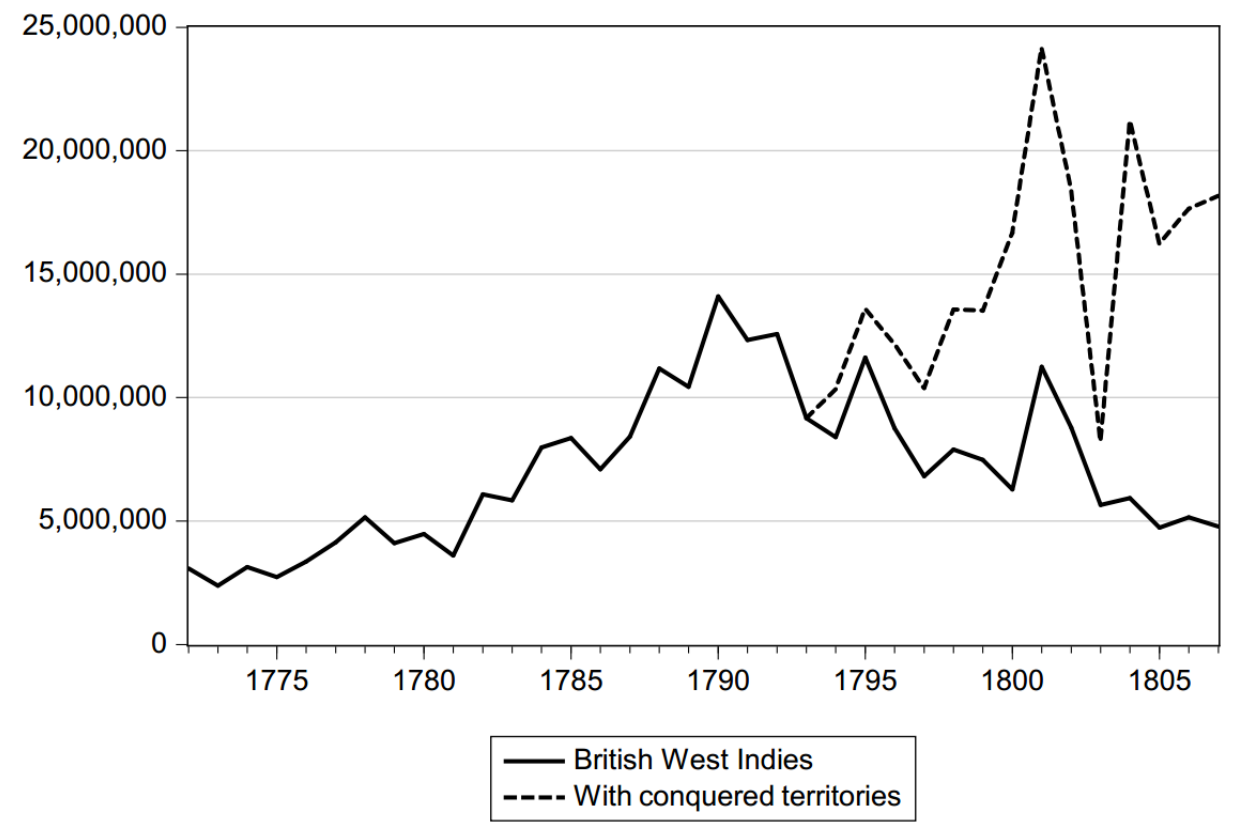

Figure 2.4 - Britain, imports of raw cotton from the West Indies, 1772-1807 (pounds) Source: 1772-1807 State of Navigation, Commerce and Revenue (BNA CUST 17)

The 1760s saw an increase in Britain's cotton consumption requiring a "frontier expansion" of its colonies in the West Indies, but for a while, British dominions shared two obstacles to expanding the cotton plantations. First, cotton had to compete for resources with sugar, the most profitable commodity in the West Indies: in 1770 cotton represented three 
percent of total value in West Indies exports, while sugar totaled 52 percent. ${ }^{123}$ The relatively limited size of the Caribbean islands compared to the frontier expansion possibilities available in areas both north and south of the American continent was also a concern.

Table 2.6 shows that the increase in Caribbean cotton exports was directly related to territorial expansion. After the Seven Years' War and through the 1763 Treaty, the former French possessions of Dominica, Grenada, St. Vincent, and Tobago, became British possessions and rapidly became important exporters of cotton. ${ }^{124}$ The missing information in Table 2.6 refers to periods during which the respective islands were not in British possession, the most important example being between 1778 and 1782, when the French seized Dominica, Grenada, and St. Vincent from Britain during the United States Revolutionary War. ${ }^{125}$ These territories returned to Britain when the war ended in 1783 and exports returned to their previous trend. Despite the repossession, the war renewed concerns about the West Indies as a reliable supplier of raw cotton. Furthermore, the Caribbean islands remained Britain's only American possession after the United States became independent, and became the center of British foreign trade in the Atlantic economy. ${ }^{126}$

Table 2.6 - Share of raw cotton exports to England from the British West Indies

\begin{tabular}{lrrrrrrr}
\hline & Bahamas & Barbados & Dominica & Grenada & Jamaica & St.Vincent & Tortola \\
\hline $1768-71$ & & 4.6 & 25.4 & 27.0 & 19.1 & 2.1 & 10.5 \\
$1772-75$ & 0.4 & 6.2 & 13.4 & 34.7 & 19.4 & 8.1 & 7.9 \\
$1776-79$ & 0.2 & 7.7 & 4.3 & 24.7 & 17.4 & & \\
$1780-83$ & 0.2 & 10.9 & & & 19.1 & & \\
$1784-87$ & 1.0 & 19.5 & 10.1 & 19.1 & 22.6 & & \\
$1788-91$ & 5.1 & 14.1 & 7.4 & 24.1 & 26.9 & 8.7 & 2.9 \\
$1792-95$ & 10.1 & 18.7 & 4.3 & 23.4 & 22.9 & 7.9 & 6.1 \\
$1796-99$ & 12.6 & 28.0 & 1.4 & 15.3 & 24.4 & 5.4 & 5.7 \\
$1800-03$ & 10.9 & 26.2 & 3.1 & 16.4 & 29.7 & 4.8 & 4.5 \\
$1804-07$ & 11.5 & 31.5 & 1.2 & 24.0 & 11.6 & 5.8 & 10.0 \\
\hline
\end{tabular}

Sources: 1768-71: British Custom House (BNA T 64/275/143); 1772-1807 State of Navigation, Commerce and Revenue (BNA CUST 17).

After the conflicts ended, Britain renewed its commercial ties with the French West Indies. Table 2.7 demonstrates that France became a substantial supplier to British cotton mills around the second half of the 1780s. French possessions included the islands of Guadeloupe,

\footnotetext{
${ }^{123}$ David Eltis, "The Slave Economies of the Caribbean: Structure, Performance, Evolution and Significance," in General History of the Caribbean, by Franklin W. Knight (UNESCO, 1997), 114. Coffee and rum represented 18 percent each.

${ }^{124}$ Adrian J. Pearce, British Trade with Spanish America, 1763-1808 (Liverpool University Press, 2007$), 41$.

125 Ibid.

${ }^{126}$ Michael Duffy, "The French Revolution and British Atitudes to the West Indian Colonies," in A Turbulent Time: The French Revolution and the Greater Caribbean, by David Barry Gaspar and David Patrick Geggus (Indiana University Press, 1997), 78-101.
} 
Martinique and St. Domingue (the last was considered the richest of all European colonies in the 1770s and 1780s). The number of slaves present on each island is a good way to compare their economic importance. While Martinique had a slave population of 83,000 in 1789 and Guadeloupe had a slave population of 90,134 in 1790, in 1789, Saint Domingue had a slave population of 465,000 - compared to a population of 30,000 Caucasians. In Guadeloupe, half of the slaves worked on sugar plantations while the other half worked in cotton and coffee production. ${ }^{127}$

Table 2.7 - Cotton wool imported in Britain, 1786-1787 (pounds weight)

\begin{tabular}{l|lrr}
\hline Source & & Total \\
\hline British West Indies & Barbados & $2,500,000$ & $5,025,000$ \\
& Granada & $1,250,000$ & \\
& St. Vincent & 250,000 & \\
& Dominica & 250,000 & \\
& Jamaica & 250,000 & \\
& Tortola & 250,000 & \\
& Bahamas & 250,000 & \\
French possessions & Others & 50,000 & $3,375,000$ \\
Portuguese settlements of "Brazils" & & & $2,500,000$ \\
Dutch & & & $1,500,000$ \\
Spanish & & & $1,338,805$ \\
East India & & 90,000 \\
Smyrna & & & $6,000,000$ \\
\hline Total Imported UK & & $19,828,805$ \\
\hline
\end{tabular}

Source: British Board of Trade - Cotton (BNA BT 6/140)

Table 2.7 indicates that most of Britain's raw cotton imports in 1787 actually originated from possessions of other nations, an issue that raised concerns among the British about foreign dependency, especially whether imports were predominantly controlled by France. ${ }^{128}$ In addition to its history of warfare with England, France's re-export duties were another source of dissatisfaction among British producers, as the duties increased the price of the raw material. In the $1780 \mathrm{~s}$, cotton manufacturers became an influential pressure group to "acquaint the planters and the British government with their requirements," and their actions aimed at reducing imports of raw cotton from foreign possessions. ${ }^{129}$ While commercial negotiations with France were taking place in 1786, textile manufacturers presented a tentative solution to reduce foreign dependency to the Board of Trade.

\footnotetext{
${ }^{127}$ Laurent Dubois, A Colony of Citizens: Revolution \& Slave Emancipation in the French Caribbean, 1787-1804, 1 edition (Chapel Hill, N.C: The University of North Carolina Press, 2004), 50; 53.

${ }^{128}$ Ibid., 228.

${ }^{129}$ Edwards, The Growth of the British Cotton Trade, 1780-1815, 75.
} 
Lord Sydney, President of the Committee on Trade and Foreign Plantations, sent a letter to Whitehall on March $10^{\text {th }}, 1786$, addressing the "necessity of promoting in His Majesty's West India possessions the cultivation of cotton of the best seeds of Tobago, Cayenne, San Domingo, Berbice, Surinam, Demerara, and Brazil [...]." ${ }^{130}$ None of these regions, however, was under British rule. ${ }^{131}$ The letter was in response to the request made by Manchester manufacturers to expand the supply of finer raw cotton and it gave examples of seeds with higher prices on the Liverpool market. While British West Indies prices ranged from 19 to 22 pence per lb.; Berbice, Surinam, Demerara, and Cayenne reached 24 pence in $1780 .{ }^{132}$ In 1787, Sidney notified the British government that the governor of Dominica - a British possession had requested permission to grant land to persons "residing upon that island for the cultivation of cotton." 133

Other colonies also benefited from British government incentives for improvements in cotton cultivation and strove to raise their productivity. In 1788 a cotton gin was introduced in the Bahamas and proved "to be an important break-through since it cleaned large amount of cotton more quickly and efficiently than the traditional methods." ${ }^{134}$ Even islands which did not traditionally plant cotton, such as Bermuda, received incentives to promote its cultivation. The Governor of Bermuda, William Browne, replied to Lord Sidney in 1787 stating he would notify the inhabitants of the island "his Majesty's pleasure respecting the cultivation of cotton." Browne also described the problems of growing cotton on islands. While arguing that the experience of many planters proved that cotton could be grown with success, the strong winds that blew across Bermuda posed a threat to the crops. The winds destroyed the cotton plants during critical periods in their development. ${ }^{135}$

Two years later, political events, not geographical limitations, reinforced Britain's ambitions to expand its cotton plantations throughout the Caribbean. British colonial governors reported "tumultuous reaction" in the French colonies in the end of 1789, after the revolution in France. The political upheaval led the British government to devise a way of reaping the benefits of France's political uncertainty. The Governor of Dominica, in a report of December 1790, argued that England could attempt to seize the French islands in view of the high

\footnotetext{
130 "The National Archive of the UK BT 6/140," fol. 17.

131 Tobago - Britain (until 1781), France (until 1814); Cayenne (France); San Domingo (France); Berbice, Surinam and Demerara (Netherlands).

${ }^{132}$ Wadsworth and Mann, The Cotton Trade and Industrial Lancashire, 1600-1780, 523.

133 "The National Archive of the UK BT 6/140," fol. 16.

${ }^{134}$ Edwards, The Growth of the British Cotton Trade, 1780-1815, 75; Gail Saunders, Slavery in the Bahamas, 1648-1838 (D. Gail Saunders, 2000), 23.

135 “The National Archive of the UK CO 37/40/21" February 5, 1787, The National Archives, Kew.
} 
probability of war in the region. Similarly, the British Ambassador in Paris raised the possibility of British support to the separatist movement in Saint Domingue. ${ }^{136}$

The Saint Domingue revolution was the most remarkable in a series of conflicts that swept the Caribbean during the 1790s. In the 1791 slave revolt, around 100,000 slaves destroyed sugar, coffee, cotton, and indigo plantations, and destabilized the French control of the West Indies. Soon, Guadaloupe and Martinique were also destabilized by slave insurrections. The disorder created a power vacuum that the British government took advantage of to promote territorial expansion. Through a series of negotiations between the French and British governments, an alliance was signed and French islands became British colonies in 1793. ${ }^{137}$ The French possessions of Guadaloupe, Martinique, Saint Domingo, Saint Lucia, and Tobago appear in the British Ledgers of Trade as "conquered islands" in 1795; representing almost two million pounds of raw cotton exported to England. Trinidad, which despite being a Spanish colony had a large French influence, also appears in 1797 as a conquered island. The most important territorial conquest in terms of cotton supply was the occupation of the former Dutch colonies of Demerara (1796) and Surinam (1799). ${ }^{138}$

Charles Mackenzie, author of an 1811 work about the British colonies, argued that the Dutch settlements on the coast of Guyana had attracted interest from British cotton planters since the $1780 \mathrm{~s}^{139}$ Table 2.8 shows that, with their annexation by Britain, Demerara and Surinam became important sources of raw cotton for Britain. ${ }^{140}$ In 1804, at the peak of imports from the conquered territories, 14 million of almost 15 million pounds of raw cotton were grown in Demerara. The former Dutch colonies had three qualities valued by the British government. First, they imposed no restrictions regarding cultivation areas. Second, as already mentioned, cotton planted on the continent was of higher quality than the types grown on island plantations. Third, Suriname and Demerara were outside the conflict zone established after the declaration of war in 1793 between Britain and France.

\footnotetext{
${ }^{136}$ Duffy, "The French Revolution and British Atitudes to the West Indian Colonies," 78-80.

${ }^{137}$ Dubois, A Colony of Citizens, 115.

138 Trevor Burnard, Planters, Merchants, and Slaves: Plantation Societies in British America, 1650-1820 (University of Chicago Press, 2015), 125.

${ }_{139}$ Mackenzie, Facts, Relative to the Present State of the British Cotton Colonies, 17.

${ }^{140}$ Henry Bolingbroke, A Voyage to the Demerary, Containing a Statistical Account of the Settlements There, and of Those on the Essequebo, the Berbice, and Other Contiguous Rivers of Guyana (London : R. Phillips, 1807), 140.
} 
Table 2.8 - Share of raw cotton exports to England from conquered territories in the West Indies St.

\begin{tabular}{rrrrrrrr} 
& Martinique & Domingo & St. Lucia & Tobago & Demerara & Trinidad & Surinam \\
\hline $1796-99$ & 27.2 & 2.8 & 0.5 & 12.5 & 41.3 & 12.3 & \\
$1800-03$ & 7.6 & & 2.8 & 0.3 & 63.2 & 15.5 & 10.2 \\
$1804-07$ & & & 4.1 & 0.2 & 81.3 & 4.0 & 10.5 \\
\hline
\end{tabular}

Source: 1772-1807 State of Navigation, Commerce and Revenue (BNA CUST 17)

The decline in production suffered by Caribbean islands in the 1790s is cited by the historiography of the Brazilian cotton trade as an important reason for the geographical diversification of cotton plantations that took place at the time. For example, in Guadaloupe, many plantations were abandoned, and the area used for the cultivation of cotton dropped by 75 percent between 1790 and 1799. In addition, with French naval incursions and continuous insurrections, the British soon lost the islands of Grenada, Saint Vincent, Saint Lucia, and Saint Domingue, which suffered successive changes of governments. ${ }^{141}$ At the same time, these accounts neglect to mention that, although it lost some of its territories, Britain also conquered larger ones on continental areas, which allowed production to increase.

In addition, the issues of competition for suitable land and labor with sugar plantations had been a concern for cotton growers in the West Indies islands since the beginning of the 1780s. It seems that this dispute for land and labor was a reason for interpretations that saw the fate of cotton as a result of competition with sugar growers for resources. ${ }^{142}$ Yet, as previously shown, the quality of the staple became a much more important factor in deciding where cotton should be produced. After 1790, cotton plantations moved to Surinam and Demarara because they produced better quality staple. The incorporation of former Dutch Colonies into the British Empire helps to understand why the growth of Brazilian cotton trade was not a direct result of the Caribbean revolutions of the 1790s.

\subsection{Conclusions}

When the mechanization of spinning allowed calicoes and muslins to become key products in the British economy after 1780, the demand shifted to cotton with longer and more resistant staples, available in Brazil because of previous policies set up during the Pombal era to encourage cotton production. Northeast Brazil became the main source of raw cotton to the textile industry, with the highest increase in productivity and the largest decrease in prices mostly in the yarn - in the classical period of the Industrial Revolution. Imports from Brazil

\footnotetext{
${ }^{141}$ Dubois, A Colony of Citizens, 224. By the end of the 1790s, the British had lost an estimated 60,000 soldiers to disease and battle in the Caribbean.

${ }^{142}$ Beckert, Empire of Cotton.
} 
accounted for 40 percent of Liverpool's cotton trade at the end of eighteenth century and the importance of Brazilian cotton continued at least until the end of the Napoleonic blockade, when international trade normalized and new processes enabled the production of high count yarns by mixing long staples with shorter ones.

The first export of Brazilian cotton to Britain occurred in the 1760s, but demand increased significantly only in the 1780s when the use of the water frame and the mule increased productivity in the textile sector. The initial increase in exports took place before the revolutions in the Caribbean, contradicting interpretations that linked Brazilian cotton exports to an economic downfall of the West Indies. In addition, cotton exports from the British West Indies did not decline following the Caribbean revolutions as some authors have claimed - production moved to South American territories previously owned by Holland and continued to expand in the following years. Descriptions of cotton typologies show that cotton produced in Demerara was similar to types exported by Maranhão, suggesting that the preference for cotton grown in South America was not related to the conflict in the Caribbean. It was the longer staples from continental areas that moved cotton production away from the islands of the West Indies.

Trade data also contradict previous explanations that attributed the rise of Brazilian cotton trade to the American Revolutionary War. The South in the U.S. was not a major supplier to Manchester prior to the nineteenth century. The increased use of saw-gins to process upland cotton, and the mixing of cotton staples, however, allowed the United States to overtake Brazil after the beginning of the nineteenth century. Nevertheless, Brazil continued to export cotton to Britain in significant quantities until the 1830 s, when cotton trade began to expand to other countries.

The next two chapters document the changes in the role of northern Brazil as a cotton supplier to Britain. Chapter 3 presents trade data for Brazilian cotton in British markets for the first half of the nineteenth century. With the appearance of new cotton suppliers in the European markets - especially the United States - lower prices compressed profits for planters that could not manage to increase their productivity. Chapter 4 presents calculations for production costs in Maranhão and provides a new interpretation about the causes of low profits for cotton planters in Brazil. 


\section{International markets and the cotton trade in Brazil, 1800-1860}

The mechanization of cotton spinning in Britain during the 1780s increased demand for longer cotton fibers and, consequently, benefited exporters in northeast Brazil. Before the nineteenth century, the cotton market for yarns used in calicoes and other all-cotton textiles relied mostly on exports from South America and, for cloths with lower counts, from the Caribbean. At the turn of the nineteenth century, however, as cotton markets continued to increase, technological improvements and new raw cotton suppliers reduced the natural advantages that the Brazilian long-staple possessed. First, the increased use of mules made it easier to use mixed staples, something that lowered demand for the more expensive long-staple cotton. ${ }^{1}$ Second, productivity growth in yarn production created bottlenecks in the following stages of textile production, creating a demand for weaving mechanization. ${ }^{2}$ The growth of power-looms in the first three decades of the nineteenth century slowly displaced hand weavers and accelerated demand for raw cotton. ${ }^{3}$ Because long-staple cotton had lower yields than shorter varieties, the increased use of saw-gins to process upland cotton allowed the United States to rapidly overtake other produces in the British markets at the beginning of the nineteenth century.

The impact of U.S. production after the turn of the nineteenth century is clear in Figure 3.1, which presents the share of different cotton suppliers in Liverpool. Brazil's relative decline after 1800 was momentarily reversed during the United States embargo in 1807 and the war with Britain in 1812, but its decreasing market share continued after $1819 .{ }^{4}$ Between 1800 and 1815, Brazil represented 27.9 percent of the cotton market in Liverpool, second only to the United States, with 43.3 percent. ${ }^{5}$ Data from the British Ledgers of Trade, which presents figures for all of Great Britain, show the same declining trend. ${ }^{6}$ In the following decades, the East Indies and Egypt emerged as new suppliers of raw cotton to Britain, the former surpassing

\footnotetext{
${ }^{1}$ William Lazonick, "Factor Costs and the Diffusion of Ring Spinning in Britain Prior to World War I," The Quarterly Journal of Economics 96, no. 1 (1981): 95, doi:10.2307/2936142.

${ }^{2}$ William Radcliffe, Origin of the New System of Manufacture: Commonly Called "power-Loom Weaving," and the Purposes for Which This System Was Invented and Brought into Use, Fully Explained in a Narrative, Containing William Radcliffe's Struggles through Life to Remove the Cause Which Has Brought This Country to Its Present Crisis (Stockport: J. Lomax, 1828), 12.

${ }^{3}$ C. Knick Harley, "Cotton Textile Prices and the Industrial Revolution," The Economic History Review 51, no. 1 (1998): 51.

${ }^{4}$ Douglas A. Irwin, "The Welfare Cost of Autarky: Evidence from the Jeffersonian Trade Embargo, 1807-09," Review of International Economics 13, no. 4 (September 1, 2005): 631-45, doi:10.1111/j.14679396.2005.00527.x.

5 Alexey Krichtal, "Liverpool and the Raw Cotton Trade: A Study of the Port and Its Merchant Community, 1770-1815" (Victoria University of Wellington, 2013).

6 “Ledgers of Imports Under Countries” (London, 1899 1809), CUST 4, The National Archives, Kew.
} 
Brazil during the 1830s. Egypt's share of the cotton trade, however, continued to be lower than Brazil throughout the period. ${ }^{7}$

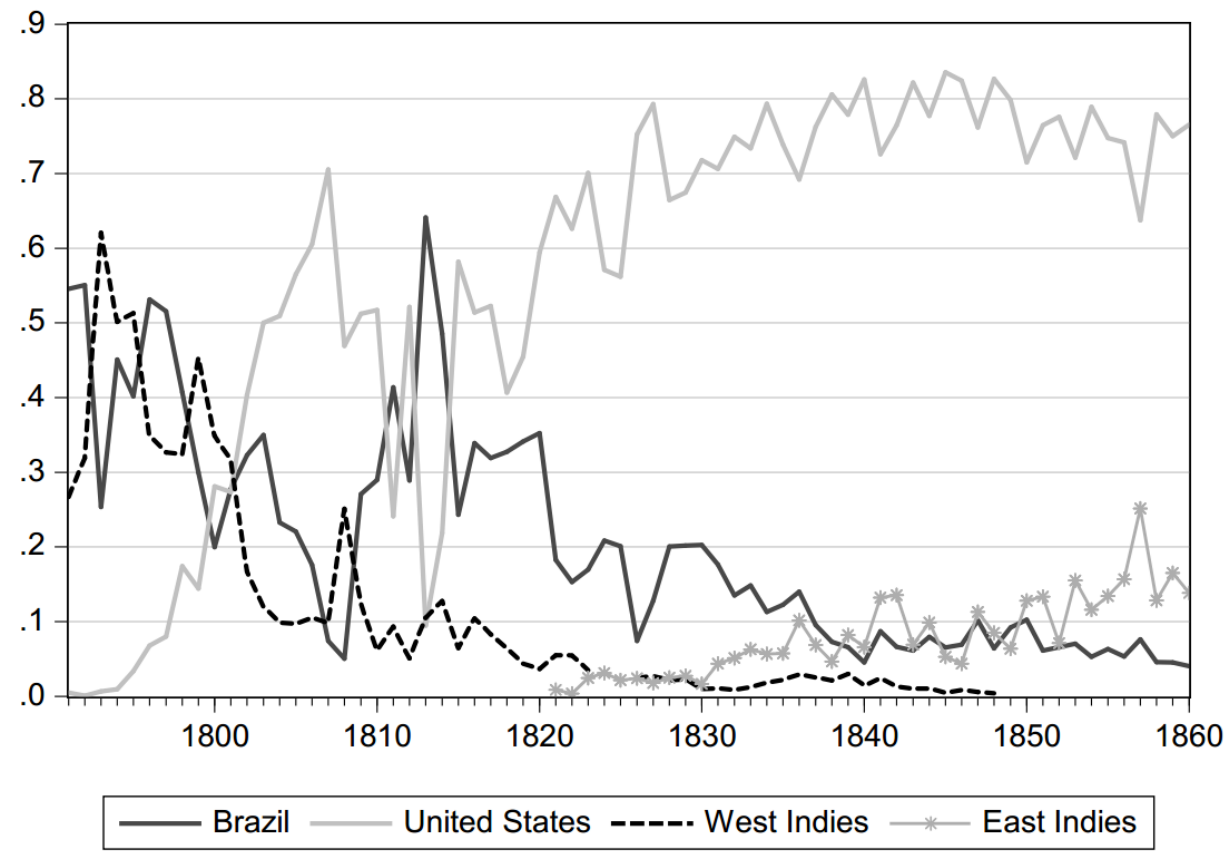

Figure 3.1 - Share of cotton imports in Liverpool, 1791-1860

Sources: Donnell, E. J. Chronological and Statistical History of Cotton; Smithers, Liverpool, Its Commerce, Statistics; Krichtal, "Liverpool and the Raw Cotton Trade"

Despite the presence of cotton planting in southern regions, such as São Paulo and Minas Gerais, for the first half of the nineteenth century Maranhão and Pernambuco dominated cotton exports. ${ }^{8}$ By volume, Maranhão was the largest cotton exporter in Brazil until the 1840s. Up until 1821, before turning into a province, Pernambuco exported almost as much cotton as Maranhão, but former trade statistics included other cotton growing regions such as Alagoas and Paraíba. Unlike other northeast regions, however, Maranhão’s economy was more dependent on cotton exports because it did not produce sugar. The share of its second commodity - rice - was too small to be an equivalent source of income for planters and the government. ${ }^{9}$

The northern provinces achieved rapid export growth until 1819 when, alongside a sharp decline in international cotton prices, production stopped growing. Exports maintained

\footnotetext{
${ }^{7}$ For the cotton economy of Egypt before 1850, see Laura Panza and Jeffrey G. Williamson, "Did Muhammad Ali Foster Industrialization in Early Nineteenth-Century Egypt?," The Economic History Review 68, no. 1 (February 1, 2015): 83, doi:10.1111/1468-0289.12063.

${ }^{8}$ Rui H. P. L. de Albuquerque, Capital comercial, indústria têxtil e produção agrícola: as relações de produção na cotonicultura paulista, 1920-1950 (São Paulo, Brasília: Editora HUCITEC, 1982), 26.

${ }^{9}$ Sebastião Ferreira Soares, "BRAZIL: Report. Cultivation of Cotton” July 23, 1861, FO 881/1003, The National Archives, Kew.
} 
practically the same level until the 1860s, when exports experienced a momentarily upsurge due to the American Civil War. Figure 3.2 shows the broad trends in cotton prices in Liverpool between 1790 and 1860. With new countries producing cotton after the end of the Napoleonic wars, price dispersion decreased significantly after 1815. Moreover, the declining trend after 1819, with temporarily reversions around 1825 and 1836, is noticeable. During the 1840s, when cotton exports in Brazil faced a major economic crisis, prices averaged $5.4 \mathrm{~d}$. in Liverpool, their lowest levels between 1800 and 1860. Prices were so low between 1845 and 1848 that even planters in the United States declared that they were losing money. ${ }^{10}$

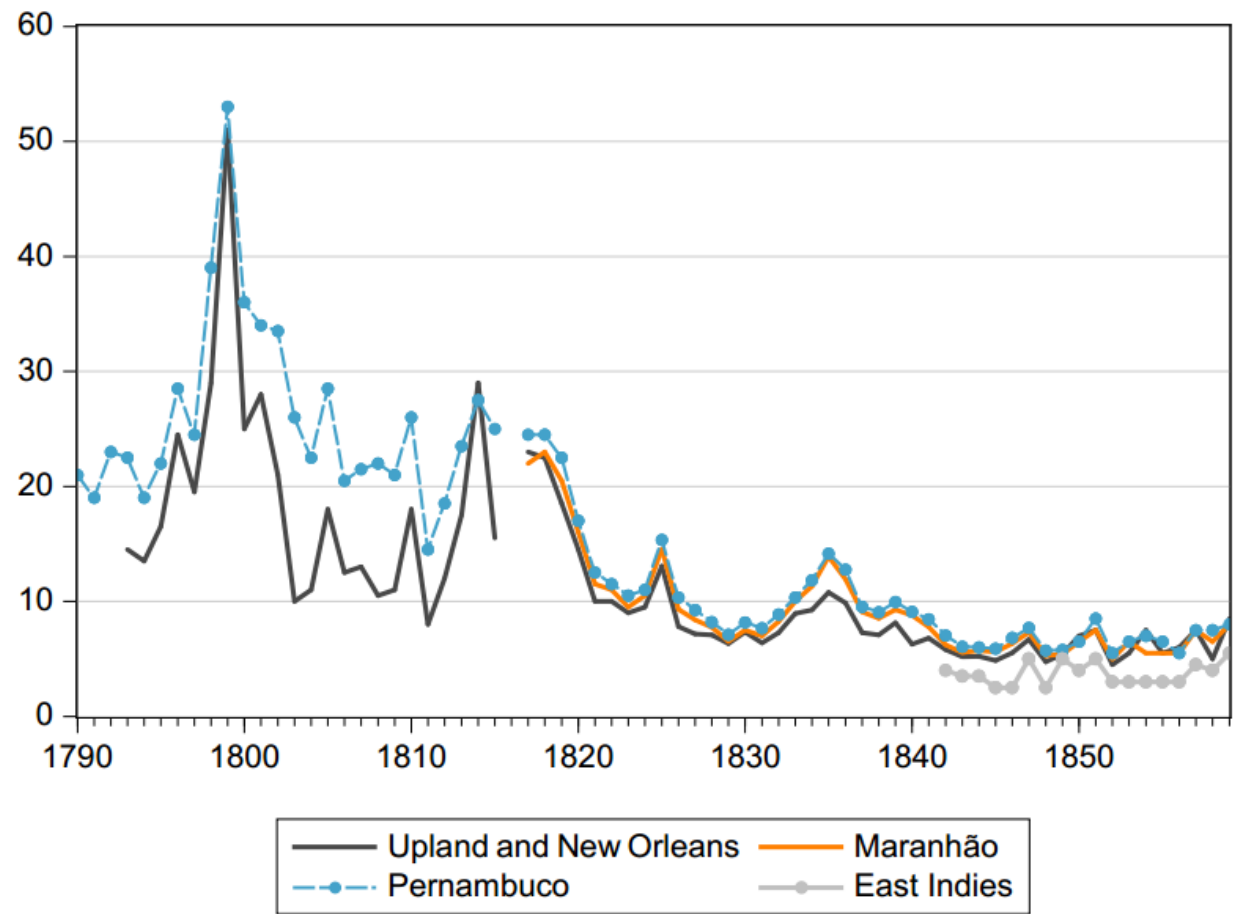

Figure 3.2 - Cotton prices in Liverpool, 1790-1860 (pence per lb.)

Sources: 1790 - 1815, Tooke, A History of Prices; 1817 - 1860 Liverpool Mercury Newspaper.

Competition and low prices represented a difficult environment for Brazilian planters, but stagnation was not an inevitable consequence. The continuous increase in cotton demand from Britain and continental Europe suggests that Brazil's stagnation was not necessarily demand driven, i.e., a result of staple substitution in the textile industry. Tests for structural breaks for the United States, East Indies, and Egypt (see appendix), which represent the three main cotton grades used in the textile sector, show that there was no decrease in the average amount of cotton exported to Liverpool between 1820 and 1860.

\footnotetext{
${ }^{10}$ Thomas Ellison, A Handbook of the Cotton Trade: Or a Glance at the Past History, Present Condition, and Future Prospects of the Cotton Commerce of the World (London: Longman, Brown, Green, Longmans, and Roberts, 1858), 17.
} 
While demand for all cotton varieties grew, Brazilian exports not only stopped growing, but decreased between 1837 and 1848. Pernambuco's economy was less affected during the 1840s because the region produced higher quality cotton, which had fewer competitors: among the higher quality staples, both Sea Island and Egyptian cotton had higher prices than Pernambuco in Liverpool. Maranhão, however, was hit hard by the depression in prices. The economic crisis of the 1840s led politicians in Maranhão in the following decade to offer several reasons - shared by subsequent scholars who studied the Brazilian cotton trade - for why exports did not manage to stay competitive. Among them, the most prominent explanations were high transports costs, insufficient labor, poor education, and lack of credit. ${ }^{11}$ These factors, along with declining prices in international markets, can be summed up in the following manner: high production costs made extensive growth unfeasible, and low productivity made cotton unprofitable with very low prices. ${ }^{12}$

While it is possible that each factor mentioned above had a significant contribution to Brazil's demise as an important cotton supplier, the literature that discusses the stagnation of cotton exports does not offer sufficient quantitative information to evaluate how much each factor contributed to the planters' production cost. ${ }^{13}$ In addition, as the difficulties cotton planters faced were well known, why was there no attempt to increase productivity, both at plantations - such as the adoption of ginning technology - or via public goods? If there were attempts, however, why were they not successful?

From a broader perspective, the fact that the northeast had a comparative advantage in two of the most important commodities of the nineteenth century and still had no growth in income per capita is truly a puzzle. ${ }^{14}$ David Denslow finds that even considering the protectionist measures of Europe and the United States, Brazilian sugar had low productivity growth compared to competitors. The Cuban sugar industry, which faced similar trade barriers,

\footnotetext{
11 "Relatorio Do Presidente Da Provincia Do Maranhão, O Doutor Eduardo Olimpio Machado, Na Abertura Da Assembléa Legislativa Provincial No Dia 3 de Maio de 1854, Acompanhado Do Orçamento Da Receita E Despeza Para O Anno de 1855.” (Maranhão, 1854), Center for Research Libraries, Global Resources Network, http://brazil.crl.edu/bsd/bsd/352/.

${ }^{12}$ Francisco de Assis Leal Mesquita, Vida e morte da economia algodoeira do Maranhão: uma análise das relações de produção na cultura do algodão, 1850/1890 (Universidade Federal do Maranhão, 1987), 229.

${ }^{13}$ Luiz Cordelio Barbosa, "Cotton in 19th Century Brazil: Dependency and Development" (University of Washington, 1989); Stanley J. Stein, Origens e evolução da indústria têxtil no Brasil: 1850-1950 (Rio de Janeiro: Editora Campus, 1979); Nathaniel H. Leff, "Economic Development and Regional Inequality: Origins of the Brazilian Case," The Quarterly Journal of Economics 86, no. 2 (1972): 243-62, doi:10.2307/1880562; Mesquita, Vida e morte da economia algodoeira do Maranhão; Alice P. Canabrava, O Desenvolvimento Da Cultura Do Algodão Na Província de São Paulo, 1861-1875 (São Paulo: EDUSP, 2011).

${ }^{14}$ Celso Furtado, Formação econômica do Brasil (Companhia das Letras, 2006), 159.
} 
managed to increase its productivity through larger production units. ${ }^{15}$ The causes of cotton stagnation, therefore, are also part of a larger question in Brazilian economic development: why did the northeast fall behind during the nineteenth century?

Among the attempts to explain Brazilian regional economic divergence, Nathaniel Leff argued that the northeast "experienced a nasty case of the Dutch Disease." ${ }^{16}$ According to Leff, as the coffee economy expanded and provided most of Brazil's foreign-exchange, the overall exchange rate was higher than the necessary level for sugar and cotton to stay competitive in international markets. Denslow, however, criticized Leff's view that the northeast would be better off if it had been a separate political unit, with its own currency. The reason was that there was "no evidence" of the overall effect of the coffee sector on the exchange rate during different periods of the nineteenth century. ${ }^{17}$ According to Denslow, for the cotton economy, there were more important difficulties that planters faced than possible exchange rates misalignments, such as production costs and exports taxes. ${ }^{18}$

The problem, once again, was that Denslow did not provide evidence to test his hypotheses. Therefore, this and the following two chapters attempt to overcome part of the data limitations faced by the literature on cotton production in northeast Brazil. This chapter analyses mostly foreign factors - like the United States' cotton trade, British demand, transport costs, and exchange rates - that affected cotton production in Brazil. In addition, to fill gaps in the trade statistics during the early nineteenth century, this chapter relies on trade reports from British consuls between 1812 and 1842, as well as data from the Portuguese balance of trade before 1809, and Maranhão's Presidential reports after 1846 to present new information on Maranhão's balance of trade for more than six decades. As export data for the first half of the nineteenth century are often used as a proxy for economic activity in Latin American coastal areas, the new trade information supports the view regarding the economic stagnation in Brazil after independence.

\footnotetext{
${ }^{15}$ David Denslow, Sugar Production in Northeastern Brazil and Cuba, 1858-1908 (New York \& London: Garland Publishing, 1987), 3.

${ }^{16}$ Nathaniel H. Leff, "Economic Development in Brazil, 1822-1913," in How Latin Amrica Fell Behind: Essays on the Economic Histories of Brazil and Mexico, 1800-1914, ed. Stephen H. Haber (Stanford: Stanford University Press, 1997), 35.

${ }^{17}$ David Denslow, “As Origens Da Desigualdade Regional Do Brasil," in Formação Econômica Do Brasil: A Experiência Da Industrialização, ed. Flávio Rabelo Versiani and José Roberto Mendonça de Barros (São Paulo: Saraiva, 1978), 52.

${ }^{18}$ Ibid., 60.
} 


\subsection{Cotton production in the United States}

The United States' rise as the largest cotton exporter in the world during the nineteenth century is a well-known phenomenon. Before 1800, however, cotton exports from the U.S. were virtually nonexistent. ${ }^{19}$ After changes in production and transport systems, however, the Deep South flooded British markets with their raw cotton. The U.S. rose from exporting less than 100 bags in 1791 to around 100,000 bags of cotton in $1806 .{ }^{20}$ During the first decades of the nineteenth century, the U.S. South became known as the "Cotton Kingdom" and, in 1850, approximately three quarters of all rural slaves in the country worked in the cotton production areas. ${ }^{21}$ Figure 3.3 shows that, in 1821, cotton plantations were already spread all over the southern states. Growth continued until the outbreak of the Civil War in the 1860s, which caused a disruption in supply to foreign markets, known as the "cotton famine." This period gave a renewed impulse to Brazilian production, which lasted until the 1870s, when the United

States regained its role as the leading exporter. ${ }^{22}$

\footnotetext{
${ }^{19}$ Douglass C. North, The Economic Growth of the United States: 1790-1860, First Edition (New York: W. W. Norton \& Company, 1966).

${ }^{20}$ James Butterworth, A Complete History of the Cotton Trade: Including Also, that of the Silk, Calico-Printing, \& Hat Manufactories; with Remarks on Their Progress in Bolton, Bury, Stockport, Blackburn, and Wigan, to Which Is Added, an Account of the Chief Mart of These Goods, the Town of Manchester (Manchester: C.W. Leake, 1823).

${ }^{21}$ Stanley L. Engerman, "Slavery and Its Consequences for the South in the Nineteenth Century," in The Cambridge Economic History of the United States: The Long Nineteenth Century, ed. Stanley L. Engerman and Robert E. Gallman, vol. 2 (Cambridge: Cambridge University Press, 2000), 338.

${ }^{22}$ John R. Hanson, "World Demand for Cotton during the Nineteenth Century: Wright's Estimates ReExamined," The Journal of Economic History 39, no. 4 (December 1979): 1015-21, doi:10.1017/S0022050700098739.
} 


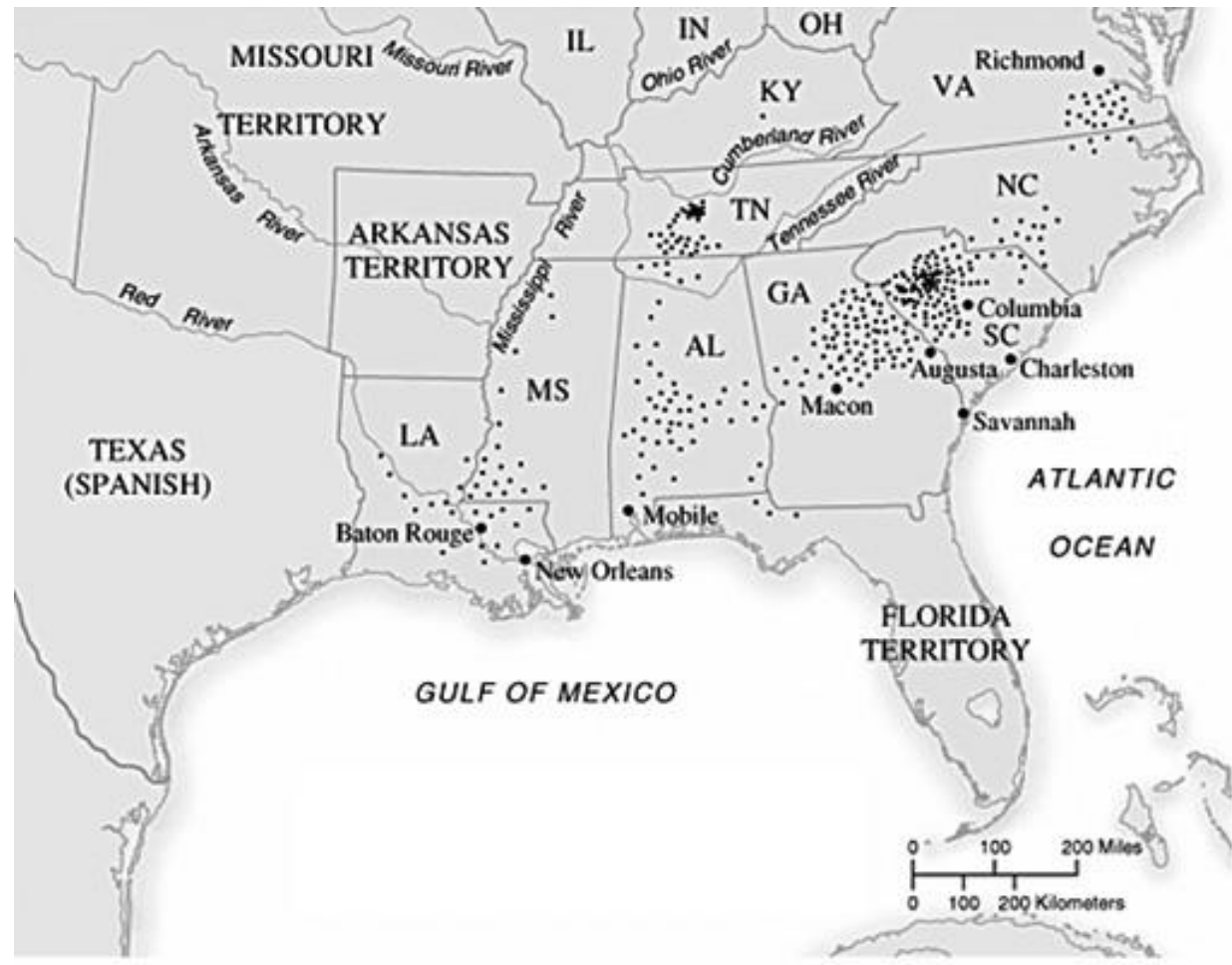

Figure 3.3 - Cotton Production in the United States, 1821

Source: Gavin Wright, The Political Economy of the Cotton South, 16. Note: Each dot represents 1,000 bales of cotton

Cotton cultivation in the United States began in South Carolina and Georgia, where for most of the eighteenth century it was grown for internal consumption. Production of raw cotton initially increased when the suspension of imports of all types of British cloth during the War for Independence created a sudden demand in the local textile sector. The increased demand for raw cotton led planters to move away from old plantations near the ports to the interior. The sudden population increase in the upcountry areas was later reinforced by migration after the War, which took place in the 1790 s. $^{23}$

Migration of cotton planting to the upcountry regions faced low production barriers because these were areas traditionally involved in tobacco cultivation, which had similar production techniques. The established network of tobacco production made easier the adoption of commercial practices such as the use of presses employed in transporting tobacco, for conditioning cotton. As tobacco was not produced for internal consumption, planters were familiar with the export trade. Thus, inland cotton expansion to regions better suited to short staple varieties helped put cotton on international trade routes. ${ }^{24}$ In the British annual statistical tables on commerce before 1808 , there are records on cotton imports from the United States

\footnotetext{
${ }^{23}$ Joyce E. Chaplin, "Creating a Cotton South in Georgia and South Carolina, 1760-1815," The Journal of Southern History 57, no. 2 (May 1, 1991): 171-200, doi:10.2307/2210413.

${ }^{24}$ Ibid., 188.
} 
beginning in the last quarter of the eighteenth century. ${ }^{25}$ Henry Smithers recounts that in 1784 an American vessel arrived at Liverpool with some bales of cotton, but likely it was not produced in the United States. ${ }^{26}$ The difficulty of establishing the real source of exports from the United States results from the fact that, before 1801, tables of exports of cotton at the Custom House did not distinguish home-grown from foreign cotton. ${ }^{27}$ Evidence suggests that before 1793 nearly all cotton shipped from the ports of Charleston and Savannah came from the West Indies, routed through the southern ports. ${ }^{28}$

The first export of cotton that originated from the United States was probably from South Carolina's Sea Islands. Its long staple and limited supply resulted in a superior quality staple, with high prices. Until 1821, the Sea Island region enjoyed prices almost twice as high as short staples in the Charleston market. With the move to the upcountry regions of South Carolina and Georgia, the short staple cotton, known as upland, was progressively adopted. Despite being inferior to the Sea Island, upland was "more hardy, could be prepared in half the time [...] and always commanded a ready sale." ${ }^{29}$ The saw-gin, usually considered as the turning point in the southern cotton trade, enabled an efficient way to process large amounts of short staple cotton. Mechanical roller gins were already used before 1790, but fibers continued to be separated from the seed by hand because the seeds in Sea Island cotton, due its long staple, could be easily removed. ${ }^{30}$ Mechanization, however, was essential for producing short staple cotton in large quantities. It is important to note, on the other hand, that the success of the commercial economy based on short-staple cotton was not simply the result from Whitney's saw-gin, and the upcountry region was already a reasonably developed economy before the cotton boom. ${ }^{31}$

\footnotetext{
25 "States of Navigation, Commerce and Revenue" (volume(s), 1808 1772), CUST 17, The National Archives, Kew.

${ }^{26}$ Henry Smithers, Liverpool, Its Commerce, Statistics, and Institutions: With a History of the Cotton Trade (T. Kaye, 1825), 124.

${ }^{27}$ E. J. Donnell, Chronological and Statistical History of Cotton. (New York: J. Stutton \& co., printers, 1872), 58, http://catalog.hathitrust.org/Record/000957820.

${ }^{28}$ Chaplin, "Creating a Cotton South in Georgia and South Carolina, 1760-1815," 175.

${ }^{29}$ G. W. Daniels, "American Cotton Trade with Liverpool Under the Embargo and Non-Intercourse Acts," The American Historical Review 21, no. 2 (January 1, 1916): 279, doi:10.2307/1835050.

${ }^{30}$ Angela Lakwete, Inventing the Cotton Gin: Machine and Myth in Antebellum America (JHU Press, 2005). Whitney's invention, with its wire-toothed design, had the tendency to damage the fiber. That is why it was not used in long staple fibers, used in higher quality products Joseph P. Reidy, "Inventing the Cotton Gin: Machine and Myth in Antebellum America. By Angela Lakwete.," The Journal of American History 91, no. 4 (2005): 145253, doi:10.2307/3660219..

${ }^{31}$ Adam Rothman, Slave Country: American Expansion and the Origins of the Deep South (Harvard University Press, 2005).
} 
With these changes, the United States clearly began to diverge from other cotton suppliers after 1800 . With the Louisiana Purchase in 1803, which nearly doubled the land area of the country, land was abundant for cotton to spread..$^{32}$ The addition of the western territories also temporarily reopened the foreign slave trade, adding at least fifty thousand new workers to the new cotton and sugar plantations. ${ }^{33}$ Nonetheless, the first reduction in U.S. exports came with the Embargo of 1807. One of the reasons for why the Embargo failed to impact British trade was because president Thomas Jefferson "overestimated the British dependence on American imports," especially cotton. ${ }^{34}$ In Brazil, the British not only found a source for raw cotton but also, with the opening of the ports in 1808, a new market for their manufactures. The Embargo severely affected the export economy of the South, which then already contained the nascent cotton region of Louisiana. ${ }^{35}$ Having to acknowledge the failure of the measure, the United States Congress terminated the embargo in 1809. Given the United States predominance in cotton exports to England in the nineteenth century, it is quite impressive that two decades before Jefferson's embargo cotton was not even considered an important staple crop. ${ }^{36}$

The second disruption in the cotton trade took place during the 1812 War, in which the "nonimportation and enemy trade acts" severely restricted trade with the British Empire. ${ }^{37}$ Still, this restrictive system did not halt trade entirely. The lowest point in U.S. South exports was reached in 1813, when President Maddison finally pushed through a law banning exports. With the end of Napoleon's Continental System in December 1813, however, the newly established embargo once again proved to be a failure and was abandoned in $1814 .{ }^{38}$ Commercial relations between the United States and Britain were reestablished in December 1814, with the Treaty of Ghent.

Table 3.1 provides information on the location of cotton plantations in the United States between 1820 and 1850. Until the 1830s, the Southeastern states, whose agriculture showed lower productivity, still were responsible for most of the cotton production. Despite the myth

\footnotetext{
${ }^{32}$ North, The Economic Growth of the United States, 32.

${ }^{33}$ Lacy Ford, "Reconfiguring the Old South: 'Solving' the Problem of Slavery, 1787-1838," The Journal of American History 95, no. 1 (June 1, 2008): 103, doi:10.2307/25095466.

${ }^{34}$ Alan Taylor, The Internal Enemy: Slavery and War in Virginia, 1772-1832, 1 edition (New York: W. W. Norton \& Company, 2013). pos 1950

${ }^{35}$ Scott P. Marler, The Merchants' Capital: New Orleans and the Political Economy of the Nineteenth-Century South (Cambridge; New York: Cambridge University Press, 2013), 19.

${ }^{36}$ Gene Dattel, Cotton and Race in the Making of America: The Human Costs of Economic Power, 1 edition (Chicago: Ivan R. Dee, 2009).

${ }^{37}$ Donald R. Hickey, “American Trade Restrictions during the War of 1812," The Journal of American History 68, no. 3 (December 1, 1981): 524, doi:10.2307/1901937.

${ }^{38}$ Ibid., 532.
} 
of the Mississippi river, which provided U.S. cotton growers lower transport costs, the largest river in the United States still played a limited role in U.S. exports when Brazilian cotton export growth began to stagnate. This condition changed during the $1850 \mathrm{~s}$, the period when, as mentioned before, most studies have surveyed the Brazilian cotton economy.

Table 3.1 - Share of cotton production in the United States, decade averages

\begin{tabular}{lcccc}
\hline & $1820 \mathrm{~s}$ & $1830 \mathrm{~s}$ & $1840 \mathrm{~s}$ & $1850 \mathrm{~s}$ \\
\hline New Orleans & 0.34 & 0.39 & 0.43 & 0.46 \\
Alabama & 0.10 & 0.15 & 0.20 & 0.18 \\
Georgia & 0.26 & 0.20 & 0.12 & 0.11 \\
South Carolina & 0.19 & 0.16 & 0.15 & 0.14 \\
Share of total production & 0.89 & 0.91 & 0.91 & 0.90 \\
\hline
\end{tabular}

Source: Donnell, E. J. Chronological and Statistical History of Cotton.

\subsection{The cotton trade in northeast Brazil, 1760-1860}

Brazilian cotton exports during the first half of the nineteenth century were concentrated in Pernambuco and Maranhão. During the 1820s, both provinces accounted for 88 percent of cotton exports in Brazil; this share was still 63 percent in the 1840s. ${ }^{39}$ The divergence in exports between Pernambuco and Maranhão after 1820, presented in Figure 3.4, occurred because before until that year exports from Alagoas, Paraíba, and Rio Grande do Norte were included in the exports from Pernambuco. ${ }^{40}$ Incorporating these provinces' production into Pernambuco's exports after 1820 yields a similar trend to Maranhão. For example, between 1841 and 1846, the average annual exports from Pernambuco (including Alagoas and Paraíba) reached 312,912 arrobas, compared to 295,070 arrobas from Maranhão. ${ }^{41}$

\footnotetext{
${ }^{39}$ Soares, "BRAZIL: Report. Cultivation of Cotton."

${ }^{40}$ Louis-François Tollenare, Notas dominicaes tomadas durante uma residencia em Portugal e no Brasil nos annos 1816, 1817 e 1818 (Impreza do Jornal do Recife, 1905), 117.

${ }^{41}$ Soares, "BRAZIL: Report. Cultivation of Cotton."
} 


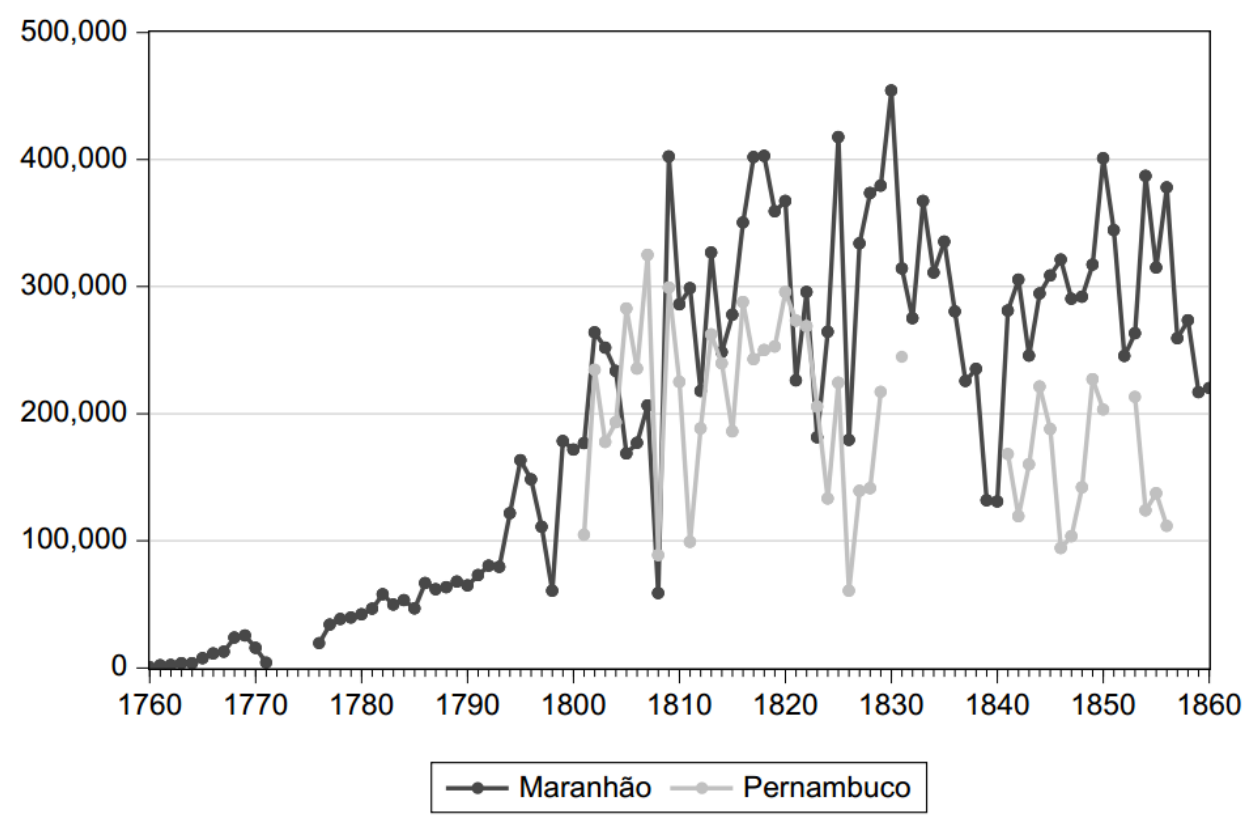

Figure 3.4 - Cotton exports from Maranhão and Pernambuco, 1760-1860 (arrobas)

Sources: Provincial Presidential Reports - Maranhão, 1861, Mapa 10. Report on the Production of Cotton in Brazil, 1861. BNA FO 881/1003.

Maranhão, therefore, was the largest cotton exporter in Brazil from 1760, when the first exports took place, until the 1840 s, when cotton production increased in other provinces. ${ }^{42}$ Unlike Pernambuco and other northeast provinces, cotton was the main commodity of Maranhão's economy, and it represented on average 80 percent of exports between 1800 and 1821, the "golden years" of export growth (4.1 percent per year). Rice, the second export product in Maranhão, occupied only a 17 percent share of foreign trade. ${ }^{43}$ While sugar was historically Pernambuco's main export, it should be noted that British demand for cotton increased so fast that cotton became momentarily the most important export crop in Pernambuco during the 1810 s. $^{44}$

Despite the cotton boom years, around 1820 cotton exports stopped growing and, in view of the declining prices, the value of exports slowly decreased as well. Between 1812 and 1836 the average annual value of exports from Maranhão was $£ 389,938$, while after 1837 it dropped to $£ 186,906$. For Maranhão, the sudden decrease in 1837 can be explained by the Balaiada revolt, in which around 11,000 men and 3,000 slaves attacked regions near the

\footnotetext{
42 Ibid.

${ }^{43}$ Antônio Bernardino Pereira do Lago, Estatística histórico-geográfica da província do Maranhão (Editora Siciliano, 1822).

${ }^{44}$ Henry Koster, Travels in Brazil (London: Longman, Hurst, Rees, Orme, and Brown, Paternoster-Row., 1816), 365; Tollenare, Notas dominicaes tomadas durante uma residencia em Portugal e no Brasil nos annos 1816, 1817 e 1818.
} 
Itapecuru river, the richest cotton region in the province. ${ }^{45}$ Despite the revolt, the decline of cotton exports was not a phenomenon restricted to Maranhão: looking at the British ledgers of trade, the annual value of British imports of Brazilian cotton was $£ 1,254,024$ before 1837 , and $£ 600,850$ after this year.

To examine whether shocks in demand for cotton could have affected Brazilian exports, I estimate regime shifts using weekly trade data for Liverpool between 1821 and $1860 .{ }^{46}$ The use of cotton trade records for Liverpool are important because Liverpool imported 80 percent of raw cotton between 1800 and 1860. Other British ports, especially London, usually imported significant quantities of lower quality cotton for non-textile industries, a market in which Brazil had a low participation. As Table 3.2 shows, Brazilian exports to Liverpool not only decreased in relative terms, but also in absolute quantities between 1837 and 1848. Trade also declined with France, the second destination of Brazilian cotton from an annual average of 21,700 bales between 1826 and 1837, to 6,165 after 1838, the volumes not recovering until 1860. France represented on average 13 percent of Brazilian cotton exports before 1837, and 5 percent after that year. Cotton trade with the rest of the European continent also fell by half after 1837 (to 7,970 bales annually), recovering only after 1848 , with an annual average of 26,416 bales until 1860.

\footnotetext{
${ }^{45}$ Jerônimo de Viveiros, História do comércio do Maranhão, vol. 1 (São Luís: Associação Comercial Maranhão, 1954), 154, 203.

46 Jushan Bai and Pierre Perron, "Estimating and Testing Linear Models with Multiple Structural Changes," Econometrica 66, no. 1 (1998): 47-78, doi:10.2307/2998540; Jushan Bai and Pierre Perron, "Computation and Analysis of Multiple Structural Change Models," Journal of Applied Econometrics 18, no. 1 (January 1, 2003): 122, doi:10.1002/jae.659.
} 
Table 3.2 - Break Points in weekly Brazilian cotton receipts (bales) in Liverpool, 1821-1860

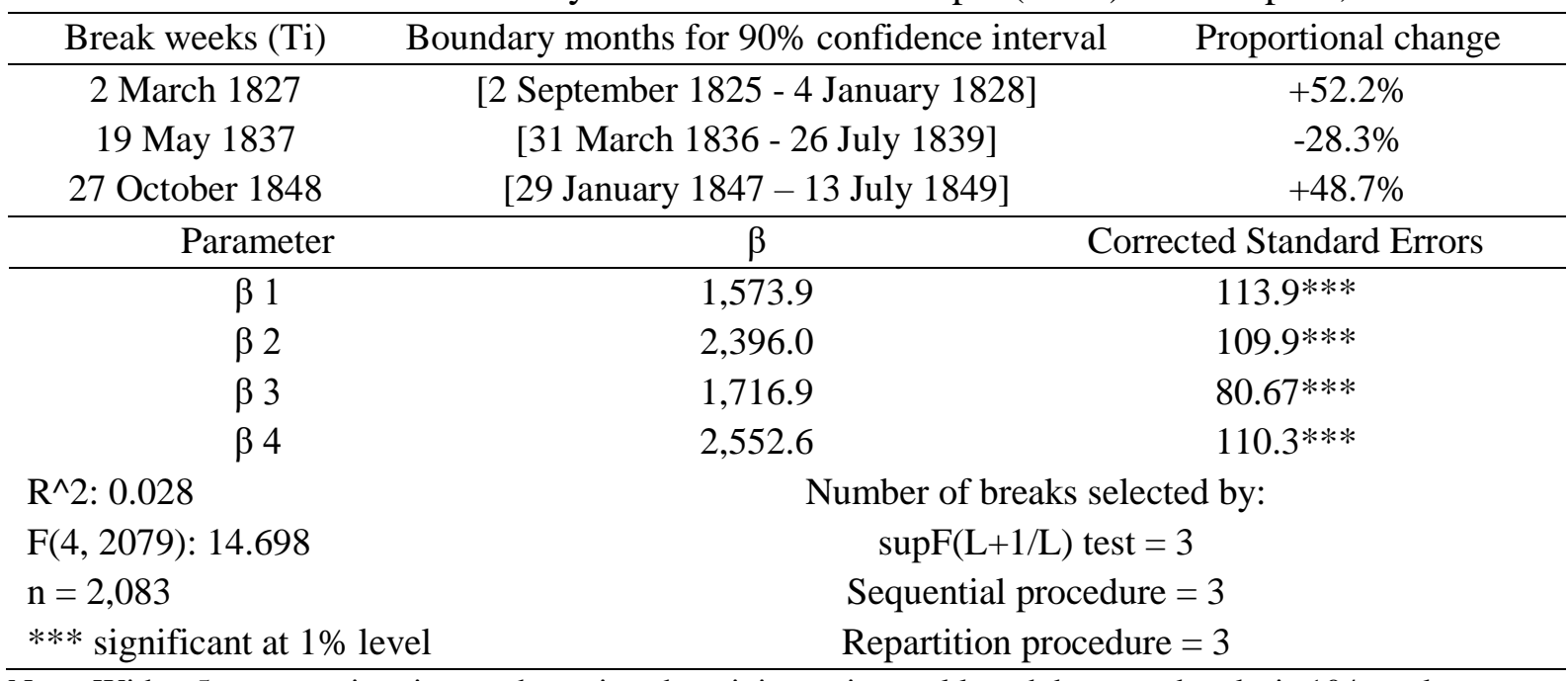

Note: With a 5 percent trimming on the series, the minimum interval length between breaks is 104 weeks. Breaks are for the last date of the old regime. Output from the estimation of the model selected by the sequential method. Weekly data from Donnell (1872)

The decrease in Brazilian exports marks a notable difference from the continuous increase presented by the overall cotton trade. Weekly data for cotton consumption in Liverpool, i.e., sales in the port after importation, shows that British consumption of raw cotton grew continuously until 1860. All breaks (reported in the appendix) had positive changes, from 7,580 bales sold on average before 1823 , to more than 41,000 weekly bales after 1854 . Trade data for the United States, the East Indies, and Egypt, which were, along with Brazil, the most important cotton suppliers to Liverpool, also show increasing demand from Britain. With a weekly average of 6,117 bales before 1827 , cotton imports from the United States kept increasing and reached 27,947 bales per week after 1840 . Even economic crises such as the Panic of 1837 do not seem to have had an enduring effect on the volume of the cotton trade between the U.S. and Britain.

Cotton from the East Indies experienced continuous growth, but the volume demanded only increased substantially during the end of the 1830s. Raw cotton from the East Indies gained importance in textile production after 1815 , when it began to be mixed with longer staples from other regions. Mixing different staples allowed India's short staple - which could not be previously spun with the machinery used at the time - to be used in the mule and spinning frames. ${ }^{47}$ During the 1850 s, nevertheless, cotton produced in the East Indies was still mainly utilized for counts between 18 and 24, a different market than Brazilian cotton. ${ }^{48}$

\footnotetext{
${ }^{47}$ E. J. Donnell, Chronological and Statistical History of Cotton. (New York: J. Stutton \& co., printers, 1872), 68.

48 “O Algodão," O Auxiliador Da Industria Nacional, December 1853, 6 edition, sec. Industria Agricola e Rural, 201, Memória Digital, Biblioteca Nacional.
} 
To understand the changes in the market for Brazilian cotton, therefore, it is necessary to know its direct competitors, as the cotton market in Liverpool was segmented. In the early nineteenth century, descriptions of cotton markets in the northeast stated that the long-stapled cotton from Pernambuco competed with the United States' Sea Island, while Maranhão’s staple, with its shorter fiber, had similar properties to the cotton from Georgia and New Orleans. ${ }^{49}$ Despite the cultivation of longer staples in Maranhão (in the region of Alcântara), most exports competed with the shorter staples from the U.S., which had the largest increase in productivity during the nineteenth century. Pernambuco, on the other hand, competed with a higher quality staples, which did not have an elastic supply: while U.S. exports of fuzzy seed cotton increased from 113 million lbs. in 1820 to more than 1.1 billion lbs. in 1860, Sea Island cotton exports did not increase in those decades, averaging 9.5 million lbs. per year..$^{50}$ This was not far from the total exports from Pernambuco between 1800 and 1860, with an annual average of 6.3 million lbs. Price information in Figure 3.5 confirms the difference between the Brazilian types of cotton, showing that Pernambuco's staple achieved higher prices than Maranhão's in Liverpool throughout the nineteenth century.

\footnotetext{
${ }^{49}$ Raimundo José de Souza Gayoso, Compendio Historico-Politico Dos Principios Da Lavoura Do Maranhão (Paris: Officina de P.-N. Rougeron, 1818), 266.

${ }^{50}$ James A. Mann, The Cotton Trade of Great Britain: Its Rise, Progress and Present Extent (Simpkin, Marshall, 1860), 99.
} 


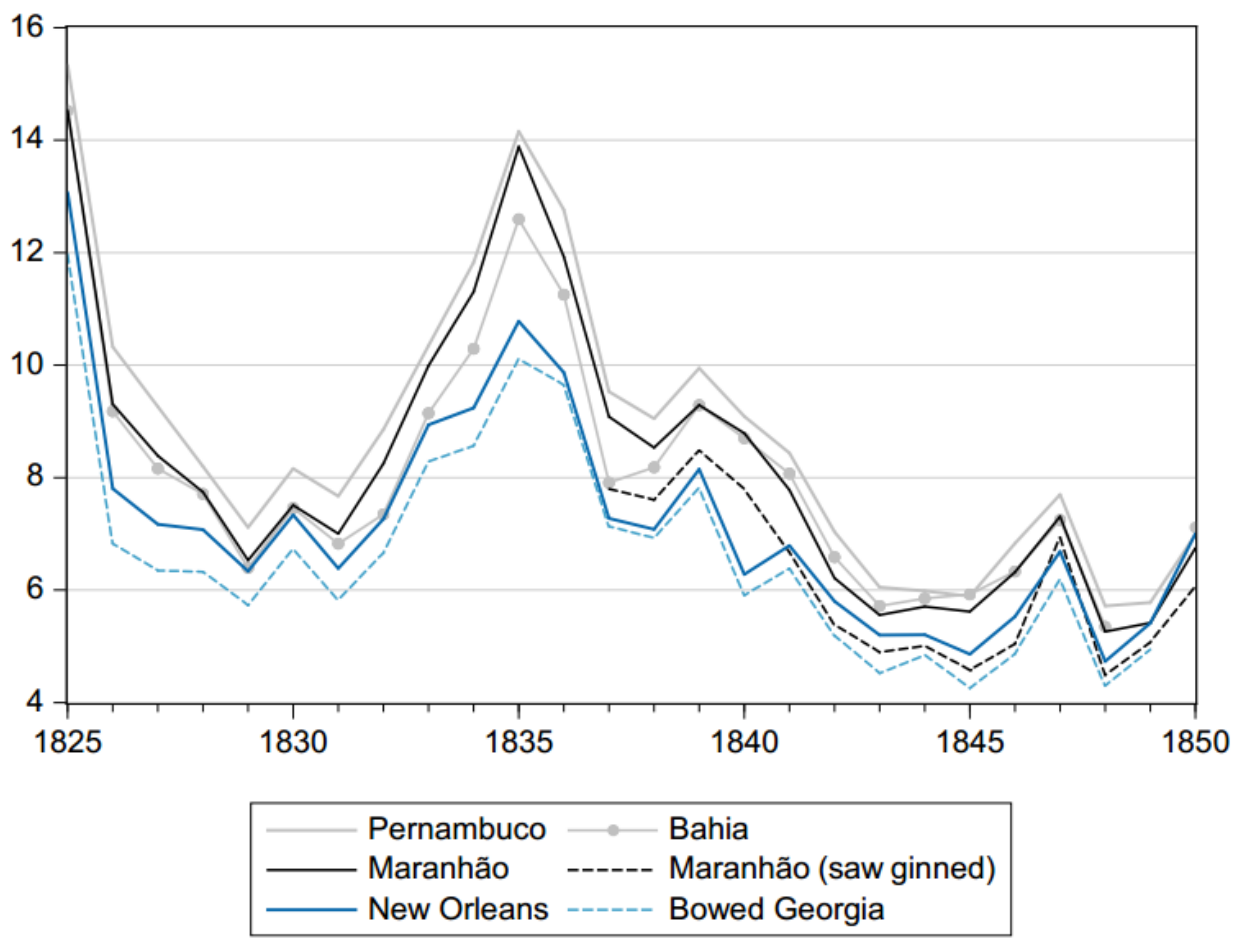

Figure 3.5: Cotton prices in Liverpool 1825 - 1850

Source: Liverpool Mercury and The Times newspapers

Maranhão, therefore, faced considerably harsher competition in the market for cotton exports than did Pernambuco. In addition to Sea Island, Egypt also exported long-staple cotton used in high quality fabrics, but initially it did not compete with Pernambuco. Egypt first exported cotton to Britain in 1823, but only significantly increased its exports to Britain during the 1840s. ${ }^{51}$ For Maranhão, therefore, competition from the U.S shorter staples would inevitably put pressure on planters to increase their productivity: Whitney's saw-gin was adopted in Maranhão during the early 1830s, and the newspaper Echo do Norte began to report prices of saw-ginned cotton in $1834 .{ }^{52}$ After 1837, newspapers from Liverpool also reported saw-ginned cotton coming from Maranhão, with prices on average 13 percent lower than the regular cotton from Maranhão. Some reports stated that the green-seed cotton (herbaceous) was introduced in Brazil from the United States only around 1840, but it seems that the saw-gins were already using fuzzy seed cotton earlier in Maranhão. ${ }^{53}$

\footnotetext{
${ }^{51}$ E. J. Donnell, Chronological and Statistical History of Cotton. (New York: J. Stutton \& co., printers, 1872), 91.

${ }^{52}$ Mesquita, Vida e morte da economia algodoeira do Maranhão, 113.

${ }^{53}$ John Branner, Cotton in the Empire of Brazil ; the Antiquity, Methods and Extent of Its Cultivation, Together with Statistics of Exportation and Home Consumption (U.S. Department of Agriculture, 1885), 31; Carlos Augusto Taunay and Padre Antonio Caetano da Fonseca, Tratado da cultura do algodoeiro no Brasil ou arte de tirar vantagens dessa plantação (Rio de Janeiro: Eduardo \& Henrique Laemmert, 1862).
} 
As Table 3.3 shows, competitive prices in Liverpool do not seem to have been the problem for Brazilian planters. Maranhão's prices for cotton that was not saw-ginned were on average $1 \mathrm{~d}$ per pound (14 percent) higher than that from New Orleans between 1825 and 1850, but the higher quality of Maranhão cotton can explain most of this difference. However, when price differentials between port of departure and arrival are considered, the gap between ports was 2.5 higher for Maranhão. This shows that cotton sellers in Maranhão received proportionally less than exporters in the United States, reducing profit rates.

Table 3.3 - Differences in cotton prices in Maranhão, New York, and Livepool, 1825-1850

\begin{tabular}{lcc}
\hline Cotton price differences in Sterling (d) & Mean & Std. Dev. \\
\hline Price difference: "Maranhão" and "New Orleans" in Liverpool & 1.03 & 0.80 \\
Price difference: "Maranhão saw-ginned" and "Upland Georgia" & 0.36 & 0.69 \\
in Liverpool & & \\
Price difference between New York and Liverpool & 0.98 & 0.34 \\
Price difference between Maranhão and Liverpool & 2.47 & 1.18 \\
Price difference between Maranhão and Liverpool (saw-ginned) & 1.74 & 0.68
\end{tabular}

Sources: For U.S, Donnell, Chronological and Statistical History of Cotton, For Maranhão, Foreign Office Reports, The National Archives - Kew.

One can assume that a large part of the higher price gap between Maranhão and Liverpool is a result of shipping costs, but the difference includes freight rates for departing ports to Liverpool. ${ }^{54}$ As Figure 3.6 shows, freight rates between Maranhão and Liverpool were lower than from New York to Liverpool. Between 1825 and 1850, the average freight rate for a pound of raw cotton from New York was $0.38 \mathrm{~d}$., while from Maranhão it was $0.33 \mathrm{~d}$. Charter rates to ship commodities dropped all over America during the 1830s. In 1833, shipment of San Domingue coffee was less than $£ 4$ per ton, compared to $£ 6$ in the 1824. Rates for Rio de Janeiro during the same period dropped from $£ 3.10$ s to $£ 2$, and from the River Plate from $£ 4$ to $£ 2.5 \mathrm{~s}$. ${ }^{55}$ The decline in freights is comparable to Maranhão, which was $£ 4.2 \mathrm{~s}$ in 1824 and $£ 2.11 \mathrm{~s}$ in 1834.

\footnotetext{
${ }^{54}$ Freight rates information between 1825 and 1837 are from the British consuls in Maranhão, and between 1838 and 1850 from newspapers in Maranhão, especially O Publicador Maranhense. "FO 13/77 - Consuls Baldwin Sealy, Robert Hesketh, William Hesketh, John Hesketh, Foreign Various, and Consular Domestic.” 1830, The National Archives, Kew; Mesquita, Vida e morte da economia algodoeira do Maranhão, 215.

${ }^{55}$ D. C. M. Platt, Latin America and British Trade, 1806-1914: The Merchant Adventurers (Harper \& Row, 1973), 15.
} 


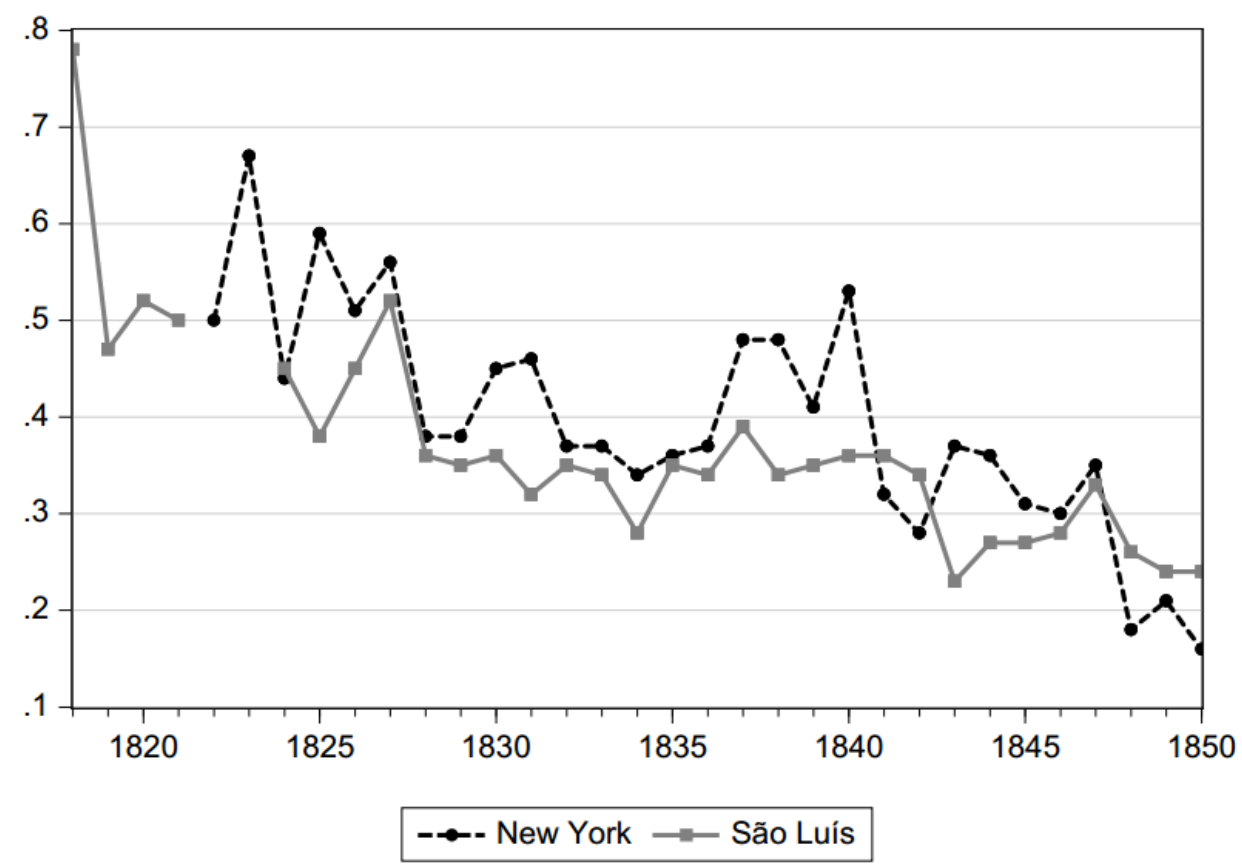

Figure 3.6 - Cotton Freight Rates between New York and São Luís to Liverpool (pence/lb) Sources: For New York, Donnell, Chronological and Statistical History of Cotton, for São Luís, Foreign Office (FO 13 and 63).

Maranhão had lower freight rates than the United States because almost all of the cotton that arrived in England from Brazil was carried by British ships. ${ }^{56}$ Unlike Brazil, data from the British Ledgers of Imports (CUST 4) shows that foreign vessels - that is, U.S. ships transported 65 percent of cotton from the United States. Thus, British dominance of the Atlantic before 1850 helped lower transport costs for Brazilian exporters. Between 1842 and 1850, when there are comparable data, freight rates for cotton between Maranhão and Liverpool were 39 percent lower than Maranhão to Lisbon, whose commodities were carried by Portuguese ships. In any case, like previous findings for other light but valuable products, freight rates represented a small cost in cotton exports. Freight rates for Maranhão cotton in Liverpool represented 4 percent of market prices between 1825 and 1850. In New Orleans freight rates reached 5 percent in the same period. ${ }^{57}$ Maritime freight costs, therefore, did not have a negative impact on cotton production in Brazil because they were similar to the prevailing rates of the much more intense traffic in the North Atlantic. What remains to be explained, however, is the reason for the greater price difference between Brazilian ports and Liverpool when compared to the United States. The next chapter will present evidence that export taxes explain a large part of this difference:

\footnotetext{
${ }^{56}$ For a discussion on British freight rates, see C. Knick Harley, "Ocean Freight Rates and Productivity, 17401913: The Primacy of Mechanical Invention Reaffirmed," The Journal of Economic History 48, no. 04 (December 1988): 851-876, doi:10.1017/S0022050700006641.

${ }^{57}$ Manuel Llorca-Jaña, The British Textile Trade in South America in the Nineteenth Century (Cambridge ; New York: Cambridge University Press, 2012), 217.
} 
subtracting the cost of export taxes reduces the price gap between Maranhão and Liverpool by 60 percent.

\subsection{The balance of trade and exchange rates in northeast Brazil}

For the first half of the nineteenth century, two periods represented significant changes in international cotton prices for Brazilian planters: the sharp drop in prices after 1819, when Britain returned to the gold standard, and the decade after 1837. Nonetheless, there were shorter periods with low prices, as during the depressions in the British cotton sector in 1812 and $1826 .^{58}$ However, the low prices at Brazilian ports in 1829, presented in Figure 3.7, cannot be explained by British markets alone. Another different price trend between Britain and Brazil happened during the 1840s when international prices declined continually and nominal cotton prices in Brazil remained relatively stable, suggesting there was significant inflation during the period. ${ }^{59}$

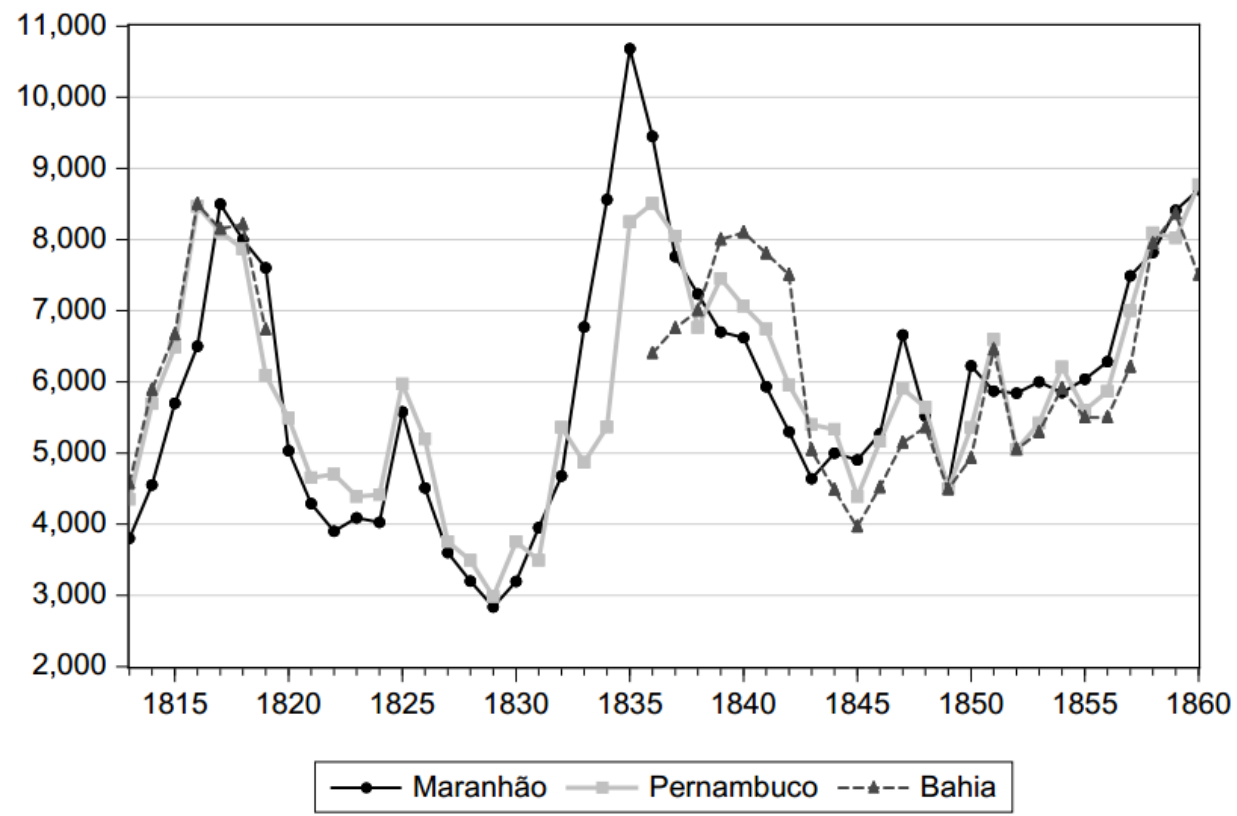

Figure 3.7 - Cotton prices from Maranhão, Pernambuco, and Bahia 1813-1860 (réis) Sources: A Idade D’Ouro Report on the Production of Cotton in Brazil, 1861. BNA FO 881/1003.

Price information from both sides of the Atlantic is important because it helps to isolate the source of fluctuations in cotton markets. For example, without knowing the exact conditions

\footnotetext{
${ }^{58}$ David J. Jeremy, Transatlantic Industrial Revolution: The Diffusion of Textile Technologies between Britain and America, 1790-1830s, First Edition, First Printing edition (North Andover, Mass. : Cambridge, Mass: The MIT Press, 1981), 52; François Crouzet, L'economie Britannique Et Le Blocus Continental, 1806-1813 (Presses Universitaires de France, 1958), 728.

${ }^{59}$ See Eulalia Maria Lahmeyer Lobo et al., "Evolução Dos Preços E Do Padrão de Vida No Rio de Janeiro, 1820-1930 - Resultados Preliminares," Revista Brasileira de Economia 25, no. 4 (October 1, 1971): $235-66$.
} 
at Liverpool at the time, domestic stagnation led the planter Raimundo Gayoso to blame in 1812 the "British speculation in the cotton market" as a factor that inhibited its development. Gayoso argued that after 1808 the number of cotton buyers in Maranhão decreased while sellers increased, enhancing the bargain power of merchants and increasing the difference in prices between São Luís and Liverpool. ${ }^{60}$ The mercantile community in Maranhão was indeed small compared to other ports, with two British commercial houses established in 1811 and thirteen one year later. ${ }^{61}$ But, in his visit to São Luís in 1811, Henry Koster reported that commercial transactions by British houses "were entrusted chiefly to Portuguese merchants of the place."62 His statement is corroborated by receipts of cotton exports found in the custom house from 1822, showing that British commercial houses mostly dealt with the transport of cotton to Liverpool - similar to what happened in New Orleans at the time. ${ }^{63}$ In 1822 , all fourteen cotton merchants that paid taxes to export the product were Portuguese. ${ }^{64}$ This included the British consul Robert Hesketh, the third largest merchant in that year, who was born in Portugal, where his father had been a wine trader. ${ }^{65}$

The organization of cotton exports in Brazil, therefore, raises doubts about simplistic explanations that attributed the fate of an industry to foreign factors. Hence, this section presents new data on two important macroeconomic indicators that help to understand the economic performance of northeast provinces during the early nineteenth century: the balance of trade and local exchange rates. Although the historiography has conventionally assumed otherwise, Maranhão and Pernambuco had persistent trade surpluses with Britain until the 1830s, which led to a higher local exchange rate than other Brazilian provinces. Furthermore, regarding the balance of trade, detailed export figures are particularly important because they are usually employed as a proxy for economic growth in Latin America during the early decades of the nineteenth century. ${ }^{66}$ The debate whether these were "lost decades," that is, with no economic growth after the independence movements, is central to all countries in the region. ${ }^{67}$ The view

\footnotetext{
${ }^{60}$ Gayoso, Compendio Historico-Politico Dos Principios Da Lavoura Do Maranhão.

${ }^{61}$ Viveiros, História do comércio do Maranhão, 1954, 1:122.

${ }^{62}$ Koster, Travels in Brazil, 182.

${ }^{63}$ John R. Killick, "The Cotton Operations of Alexander Brown and Sons in the Deep South, 1820-1860," The Journal of Southern History 43, no. 2 (1977): 176, doi:10.2307/2207344.

64 "Lista Dos Negociantes," Conciliador Do Maranhão, February 20, 1822, 64 edition.

${ }^{65}$ Ian Sargen, Our Men in Brazil: The Hesketh Brothers Abroad (Scotforth Books, 2009). Hesketh remained a merchant until 1827, when the Foreign Office prohibited British consuls to engage in commercial activities while on duty.

${ }^{66}$ Luis Bertola and Jose Antonio Ocampo, The Economic Development of Latin America since Independence (Oxford: Oxford University Press, 2012), 57.

${ }^{67}$ Robert H. Bates, John H. Coatsworth, and Jeffrey G. Williamson, "Lost Decades: Postindependence Performance in Latin America and Africa," The Journal of Economic History 67, no. 04 (2007): 917-43,
} 
of a stagnant economy before 1850 in Brazil is still regarded as the standard interpretation, although the lack of regional data makes it difficult to ascertain if low growth was uniform across the country. ${ }^{68}$

Despite rapid growth in cotton exports between 1790 and 1820, Maranhão seems to fit the pessimistic view of the "lost decades." Between 1799 and 1822 exports averaged $£ 593,322$ per year, but after independence the average in the next three decades dropped to $£ 309,019$. It should be noted, however, that a decrease in the export trade does not necessarily imply a reduction in overall economic activity, even though exports were probably the most important sector at the time. ${ }^{69}$ Evidence suggests that the relation between economic growth and trade based on natural resources depends on institutional factors. ${ }^{70}$ In the United States cotton was the most important export staple, but overall exports represented only about 9 percent of total U.S. GDP. ${ }^{71}$ With this caveat in mind, Figure 3.8 shows exports (in mil-réis) in Maranhão during three different political regimes: before 1808, when Portugal controlled all foreign trade; between 1808 and 1821, when the Portuguese Court moved to Rio de Janeiro; and after 1824, when Brazil became an independent nation.

doi:10.1017/S0022050707000447; Leandro Prados De La Escosura, "Lost Decades? Economic Performance in Post-Independence Latin America,” Journal of Latin American Studies 41, no. 02 (2009): 279-307, doi:10.1017/S0022216X09005574; D. C. M. Platt, "The Imperialism of Free Trade: Some Reservations," The Economic History Review 21, no. 2 (August 1968): 296, doi:10.2307/2592437.

${ }^{68}$ Celso Furtado, Formação econômica do Brasil (Companhia das Letras, 2006); Nathaniel H. Leff, “A Technique for Estimating Income Trends from Currency Data and an Application to Nineteenth-Century Brazil," Review of Income and Wealth 18, no. 4 (December 1, 1972): 355-68.

${ }^{69}$ André Arruda Villela, “Exclusivo Metropolitano, 'superlucros' e Acumulação Primitiva Na Europa PréIndustrial,” Topoi (Rio de Janeiro) 12, no. 23 (December 2011): 4-29, doi:10.1590/2237-101X012023001.

${ }^{70}$ Halvor Mehlum, Karl Moene, and Ragnar Torvik, "Institutions and the Resource Curse," The Economic Journal 116, no. 508 (January 1, 2006): 1-20, doi:10.1111/j.1468-0297.2006.01045.x; Guy Michaels, “The Long Term Consequences of Resource-Based Specialisation,” The Economic Journal 121, no. 551 (March 1, 2011): 31-57, doi:10.1111/j.1468-0297.2010.02402.x.

${ }^{71}$ Douglas A Irwin, “The Optimal Tax on Antebellum US Cotton Exports," Journal of International Economics 60, no. 2 (August 2003): 287, doi:10.1016/S0022-1996(02)00052-1. 


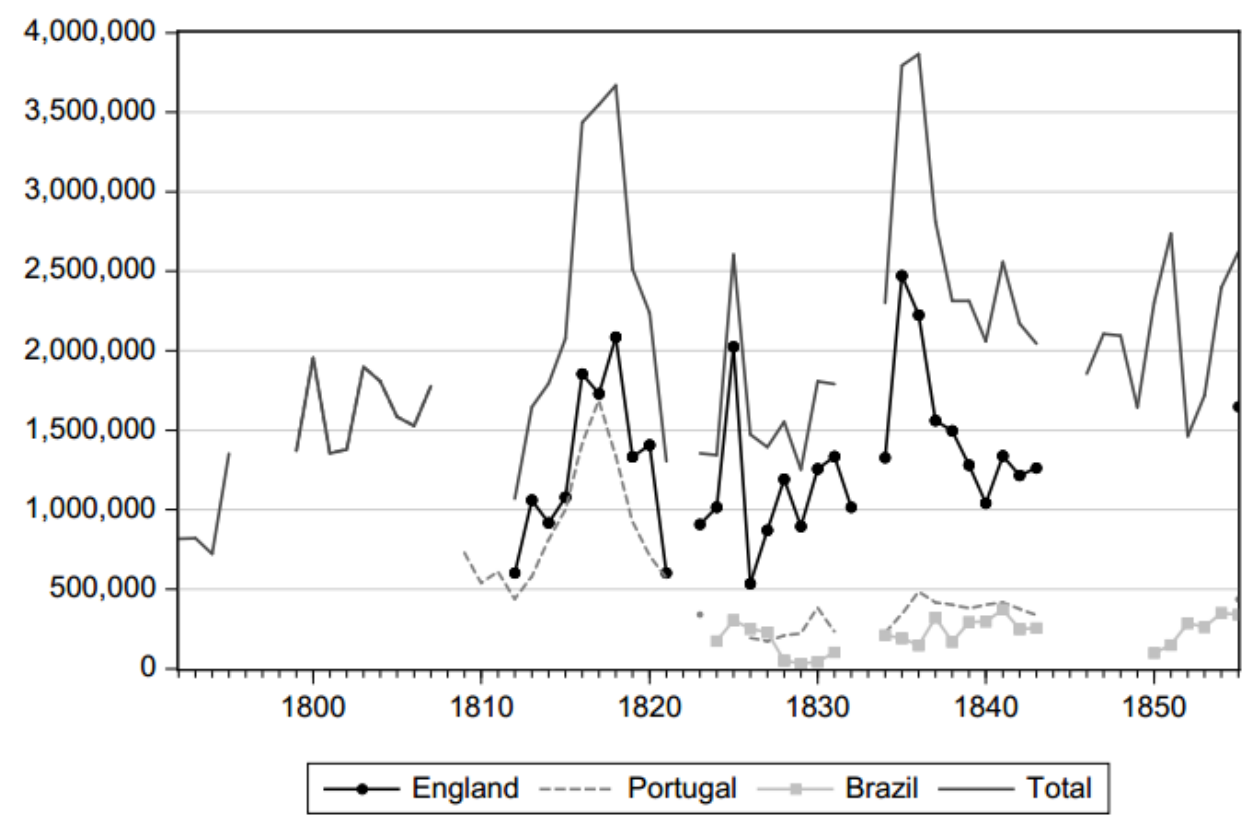

Figure 3.8 - Maranhão Exports (mil-réis), 1792-1855

Sources: Viveiros, História do comércio do Maranhão (1792-95); Balanças de Comércio de Portugal (1799-1811); Lago, Estatística histórico-geográfica (1812-1821); Foreign Office Reports FO 13 and 63 (1823-31); Provincial Presidential Reports (1838-1855).

Variations in the value of Maranhão's exports were highly dependent on international cotton prices, as the period between 1816-18 and 1836-38 shows. Cotton represented 80 percent of total export value between 1800 and 1821 and nothing less than 68 percent of the cotton exported after 1808 went to England, increasing to 83 percent after independence. ${ }^{72}$ Even though the political crisis created by the transfer of the Portuguese royal family affected Brazilian trade, the reduction in exports between 1809 and 1812 was mostly a consequence of a decline in international prices - cotton prices achieved a low level of $3 \$ 000$ in $1812 .{ }^{73}$

Maranhão's dependence on Britain was reinforced by geographical barriers and governmental policies that reduced trade with other regions in Brazil. Trade with Brazilian regions averaged 10 percent in the decades after independence. In an age of sail, sea currents made it easier to reach markets in Europe than southern provinces in Brazil. ${ }^{74}$ Moreover, the imperial government made commerce with other Brazilian markets costlier with a muchcriticized transit tax on commerce between provinces by land and sea, which ended only in

\footnotetext{
72 "FO 13/77 - Consuls Baldwin Sealy, Robert Hesketh, William Hesketh, John Hesketh, Foreign Various, and Consular Domestic.”; Lago, Estatística histórico-geográfica da província do Maranhão.

${ }^{73}$ Jorge M. Pedreira, "From Growth to Collapse: Portugal, Brazil, and the Breakdown of the Old Colonial System (1760-1830)," Hispanic American Historical Review 80, no. 4 (November 1, 2000): 850, doi:10.1215/00182168-80-4-839.

${ }^{74}$ Luiz Felipe Alencastro, O Trato dos Viventes (São Paulo, Brazil: Companhia das Letras, 2000), 62.
} 
$1831 .^{75}$ The transit tax added transaction costs that limited market size, affecting regional economies in Brazil.

On the opposite side of trade, imports were a lagged response to the movement of exports. The British consul in Maranhão reported in the 1820s that the demand for textiles from his home country mainly depended on the income of raw cotton exports. ${ }^{76}$ Indeed, after a major drought affected harvests in 1825, British imports reduced at a much higher rate than trade from other countries in the following year. ${ }^{77}$ Thus, following the reduction in international prices, imports in sterling dropped after independence. Between 1799 and 1822 the annual average of imports was $£ 474,034$, while from 1824 until 1855 the average was $£ 328,668$.

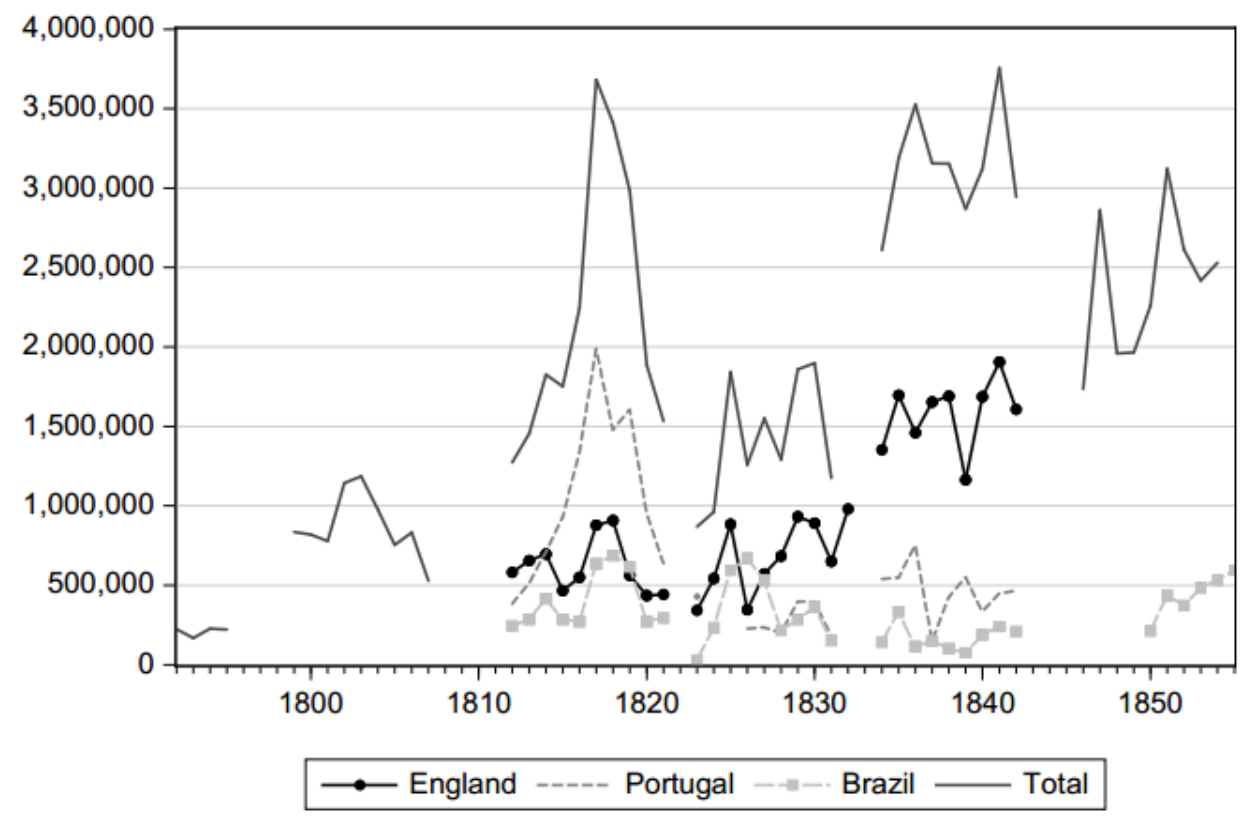

Figure 3.9 - Maranhão Imports (mil-réis), 1792-1855.

Sources: Sources: Viveiros, História do comércio do Maranhão (1792-95), Balanças de Comércio de Portugal (1799-1807); Lago, Estatística histórico-geográfica (1812-1821); Foreign Office Reports FO 13 and 63 (1823-42); Provincial Presidential Reports (1838-1855).

Figure 3.9 shows that Britain represented 30 percent of imports, and Portugal 27 percent, between 1809 and 1821. The slave trade with African ports represented 19 percent of imports until 1821. The share of African trade increased especially between 1817 and 1819, a period of high cotton prices, when it represented 27 percent of all imports. Since the slave trade was controlled by the Portuguese, Figure 3.9 adds the African traffic to Portuguese imports. After

\footnotetext{
${ }^{75}$ Candido Baptista de Oliveira, Systema financial do Brasil (S. Petersburgo: Typographia Privilegiada de Fischer, 1842), 9.

76 "FO 13/30 - Arthur Aston, Consuls John Parkinson and Robert Hesketh.” 1826, 193, The National Archives, Kew.

77 “FO 13/40 - Arthur Aston, Consuls Henry Chamberlain, John Parkinson, Robert Hesketh.” 1827, 210, The National Archives, Kew.
} 
1821, with British moves to end the slave trade north of the Equator, most slaves came from other Brazilian ports, practically ending the direct trade between Maranhão and African ports.

Between 1822 and 1842 (when there are detailed data available), Maranhão's imports from Britain increased to 49 percent, whereas Portugal's share decreased to 14 percent. The rise of the British share also resulted from a decrease in trade with other countries. The sudden fall in Portuguese imports after 1822 was related to the order (in December, 1822) by the new Brazilian government to seize all Portuguese goods at Brazilian ports, along with an import tariff increase for many Portuguese products, such as wines. ${ }^{78}$

Apart from slaves, textiles from Britain were the most important product imported by Maranhão during the cotton boom years. Between 1812 and 1821, "India cottons" averaged 17.5 percent of Maranhão total imports, while foreign linen goods amounted to 6 percent. These products were mostly consumed by the upper classes, which explains why their demand was sensible to cotton prices. It was only in the 1830s that an increase in productivity of British cotton textiles became associated with mass production; before this, the largest reduction in textiles prices occurred in higher quality calicos and muslins. ${ }^{79}$ Figure 3.10 complements the information on Maranhão's foreign commerce by showing its trade with Britain in sterling, as inflation in Brazil probably distorted relative prices after 1830. Trade surpluses reversed only after 1837 when cotton began a decade long of low prices in Liverpool.

\footnotetext{
${ }^{78}$ Liberato de Castro Carreira, Historia Financeira E Orçamentaria Do Imperio Do Brazil Desde a Sua Fundação, Precedida de Alguns Apontamentos Acerca Da Sua Independencia (Rio de Janeiro: Imprensa Nacional, 1889), 90.

${ }^{79}$ John Styles, "Fashion, Textiles and the Origins of Industrial Revolution," East Asian Journal of British History 5 (March 31, 2016): 186; Harley, "Cotton Textile Prices and the Industrial Revolution."
} 


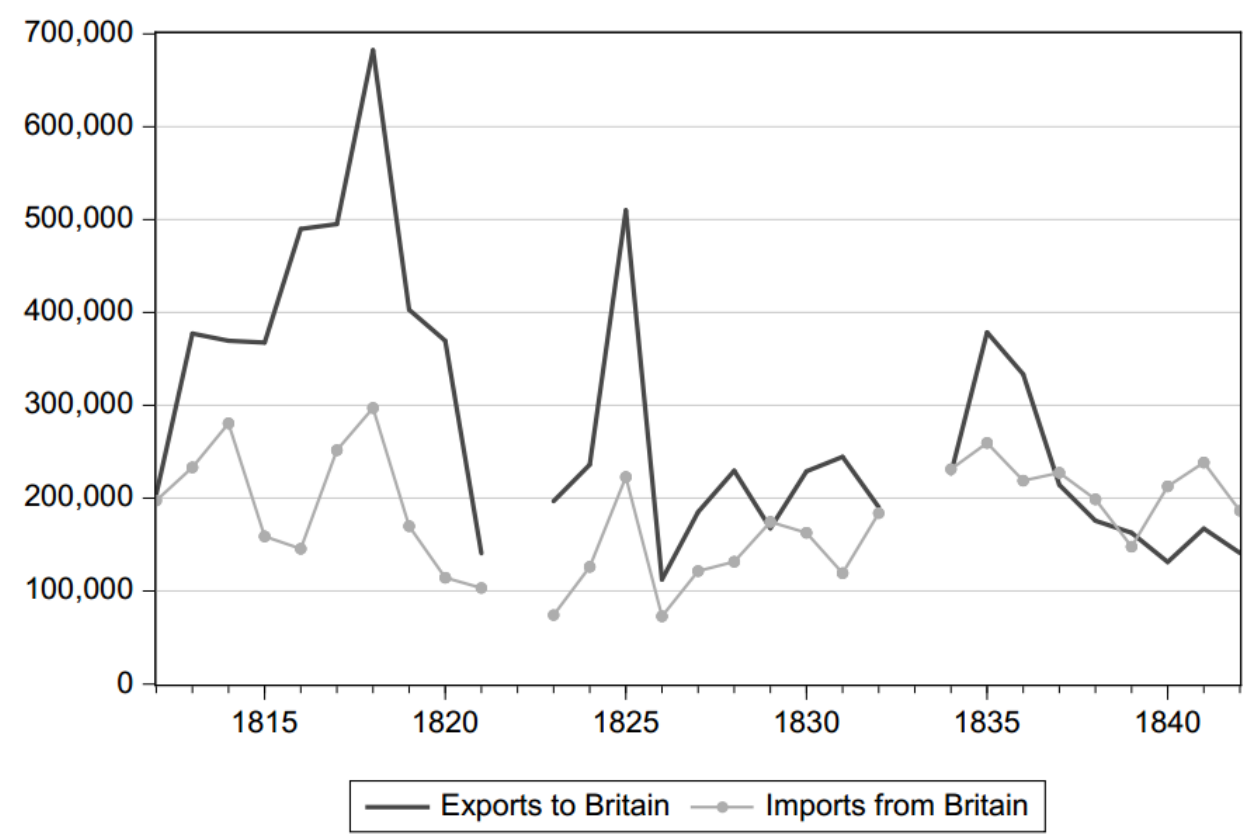

Figure 3.10 - British trade with Maranhão (£), 1812-1842

Sources: Foreign Office, Consuls Maranhão (FO 13 and 63).

Compared to other Brazilian regions after the opening of the ports, imports and exports per capita in Maranhão were higher than in Bahia and Pernambuco, usually considered the richest ports in Brazil along with Rio de Janeiro. ${ }^{80}$ Maranhão's imports were 1.19 times higher than Bahia's, while exports per capita were on average 2.43 times higher than Bahia's between 1813 and 1816. Fifty-five percent of Bahia's imports were classified under "general European goods," with printed cottons (chitas) as the most important product. Next, 17 percent of imports came from African ports (mostly slaves), and another 17 percent comprised products from Portugal and re-exports from Asia. ${ }^{81}$ One marked difference with Maranhão was Bahia's trade with Rio Grande do Sul, accounting for 12 percent of total imports. Regarding exports, sugar and tobacco represented the most important products, with cotton at a distant third place. Portuguese ports represented 58 percent of Bahian trade, while foreign ships accounted for 22 percent.

Evidence for Pernambuco suggest a trade pattern midway between Maranhão and Bahia. Per capita exports in Pernambuco reached $6 \$ 723$ in 1813, while in Maranhão it was 11\$756. In Pernambuco 49.6 percent of exports went to Britain and 32.8 to Portugal. ${ }^{82}$ With

\footnotetext{
${ }^{80}$ Manuel de Oliveira Lima, Dom Joao VI no Brazil, 1808-1821 (Rio de Janeiro: Typ. do Jornal do commercio, 1908), 148.

81 "Bahia, Comércio," Gazeta Do Rio de Janeiro, April 19, 1817, 32 edition, 3, Memória Digital, Biblioteca Nacional.

${ }^{82}$ Barbosa, "Cotton in 19th Century Brazil: Dependency and Development," 106-07. The other figures, from the Mesa de Inspecção de Pernambuco, are: United States (Imports - 1.3\%; Exports 3.2\%), Coast of Africa (Imports $11.6 \%$; Exports $21.9 \%$ ).
} 
respect to imports, Portugal and Britain had similar shares, 25.5 percent. Trade with other Brazilian provinces was much lower, and represented only 3.7 percent of imports and 18.4 percent of exports in 1813. In 1824, Pernambuco's exports amounted to 1,979 contos, with 53 percent destined to Great Britain and 35.5 percent to ports in continental Europe (France, Italy, Hamburg, and Amsterdam), most of them related to the sugar trade. ${ }^{83}$ Exports to other Brazilian provinces were scant, smaller than exports to the United States. Pernambuco's imports were more diversified and amounted to 2,152 contos, with 24.3 percent from Great Britain. Imports from Africa, including the slave trade, represented 15.8 percent, and the beef jerky trade with Rio Grande do Sul reached 17 percent.

Trade patterns in northeast Brazil, therefore, represented a much more diverse economic reality than the one portrayed by the traditional literature, which depict commercial relations with Britain after the 1810 treaty as a "permanent imbalance in the balance of trade." ${ }^{84}$ The evidence of continuous trade surpluses - at least for Maranhão - also goes against influential interpretations on why there was an economic divergence between the northeast and southern regions of Brazil during the nineteenth century. In his interpretation on why the northeast fell behind, Nathaniel Leff argued that the boom in coffee exports brought the exchange rate to a level that made sugar and cotton production uncompetitive in international markets. ${ }^{85}$ As coffee was responsible for a "Dutch disease" in northeast Brazil, Leff argued that the northeast would "have been better off as a separate political unit, with its own currency system." "86 Figure 3.11, however, which presents exchange rates for different provinces, clearly shows that Leff's hypothesis was wrong, and that the northeast provinces had higher exchange rates than the coffee region of Rio de Janeiro during the cotton boom. In fact, Rio de Janeiro's influence after 1830 was to lower the exchange rate in the northern provinces, the opposite of an expected Dutch disease effect. ${ }^{87}$

\footnotetext{
83 “FO 13/12 - Lord A. Marcus C. Hill, Consuls John Parkinson and Robert Hesketh." 1825, 43-44, The National Archives, Kew.

${ }^{84}$ Rubens Ricupero, "O problema da Abertura dos Portos," in A abertura dos portos (São Paulo: Editora Senac São Paulo, 2007), 46. Alan Krebs Manchester, British Preeminence in Brazil: Its Rise and Decline : A Study in European Expansion (Octagon Books, 1964), 92; Caio Prado Jr., História econômica do Brasil (Rio de Janeiro: Editôra Brasiliense, 1972); Patrick Wilcken, Império à deriva: a corte portuguesa no Rio de Janeiro, 1808-1821 (Rio de Janeiro: Editora Objetiva, 2005), 155.

${ }^{85}$ Leff, "Economic Development and Regional Inequality," 256.

${ }^{86}$ Ibid., 259.

${ }^{87}$ Denslow, "As Origens Da Desigualdade Regional Do Brasil."
} 


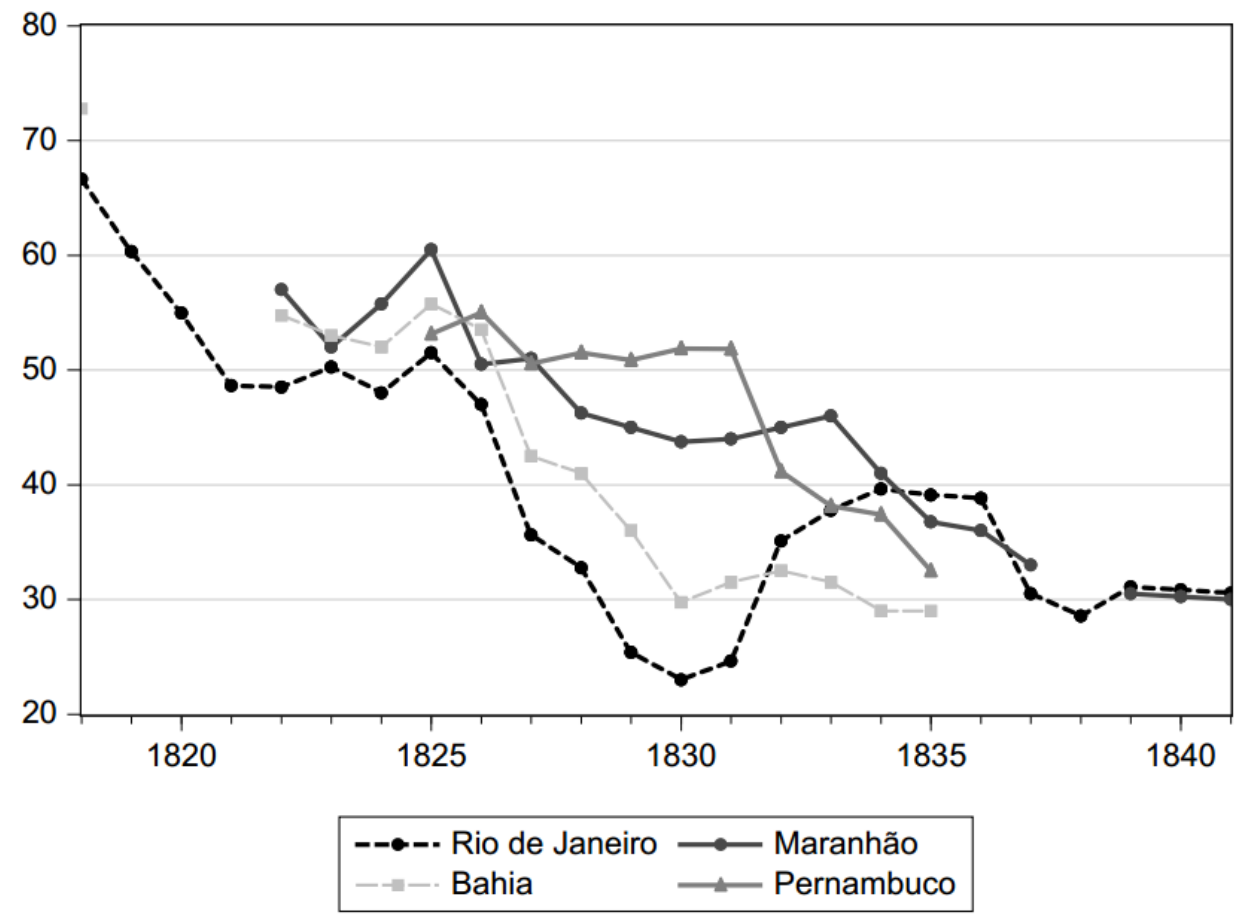

Figure 3.11 - Exchange Rates in Brazil's main ports, 1818-1841 (pence per mil-réis) Sources: Cavalcanti, O Meio Circulante Nacional, Vol.1, 321; Consular Reports, BNA FO 13 and 63.

To understand the divergence in exchange rates presented in Figure 3.11 it is essential examine Rio de Janeiro's monetary policy during the period. According to contemporary commentators, part of the currency "derangement" that took place in Rio de Janeiro right after 1808 was connected to the "extravagant splendor of" a court arriving without means, with a numerous retinue of nobility and priests without income, all having their own protégés," all of whom were determined to live at the expenses of the colony. ${ }^{88}$ Despite the potential extravagance of the royal family, most of the new monetary demands after 1808 came from the rapid changes in economic life brought with the opening of the ports and the exogenous shock of Rio de Janeiro becoming the "capital" of the Portuguese empire. Increasing expenses and insufficient gold supply led the government to adopt inflationary policies like other newly independent countries in Latin America. ${ }^{89}$

As Figure 3.11 shows, the exchange rate devaluation in Rio de Janeiro accelerated after independence, when foreign loans (1824) and the Cisplatine War (1825-28) led to an increase

\footnotetext{
${ }^{88}$ Johann Jakob Sturz, A Review Financial, Statistical and Commercial of the Empire of Brazil and Its Resources; Together with a Suggestion of the Expediency and Mode of Admitting Brazilian and Other Foreign Sugars Into Great Britain (London: E. Wilson, 1837), 3.

${ }^{89}$ María Alejandra Irigoin, "Macroeconomic Aspects of Spanish American Independence : The Effects of Fiscal and Currency Fragmentation, 1800s-1860s," IFCS - Working Papers in Economic History.WH (Universidad Carlos III de Madrid. Instituto Figuerola, 2003), 9, https://ideas.repec.org/p/cte/whrepe/wh034509.html.
} 
in paper money emissions and copper coinage. ${ }^{90}$ The increase in money supply is evident in the statistics presented by the Brazilian Finance Minister in 1829. Since its creation in 1703 through the end of 1825, Rio de Janeiro's mint (Casa da Moeda) produced 2,633 contos de réis in copper coins, but between January 1826 and March 1829 the coinage amounted to 5,241 contos. ${ }^{91}$ With respect to paper money, the government almost doubled its stock in 1827 , fueling inflation even more. In November 1827, recognizing the harmful effects of the expansionary monetary policy, the government prohibited new emissions of bills from the bank. The culmination of the monetary crisis happened when a legislative act ended the first Bank of Brazil (and its branches) in 1829, and turned its bills into fiat paper money. ${ }^{92}$ Critics wanted to liquidate the bank because they saw it as a "lending house to the government and for some individuals with influence." ${ }^{93}$ But instead of limiting money supply, the government authorized the use of bank bills as paper money in all Brazilian provinces in 1830, and officially ended the ban on copper coin exports from Rio de Janeiro and Bahia to other provinces a year later. ${ }^{94}$ These two measures spread depreciated money into Pernambuco and Maranhão, both which had access to hard currencies due to persistent trade surpluses.

Up until 1830, Pernambuco and Maranhão's trade with Britain generated exchange rates twice as high as in Rio de Janeiro. A report from the "select committee on the high price of gold bullion," ordered by the British House of Commons, provides some evidence that northern provinces - mainly because of cotton - had enjoyed favorable trade balances since the opening of the ports. The committee, trying to restrict gold outflows in a time of war, reported in 1810 the exchanges between Great Britain and foreign countries. Despite the general perception that the state of trade was in favor of Britain, the committee confirmed the existence of gold exports to Brazil. The reason was the increased demand for Brazilian cotton due to the apprehension by manufacturers of a possible political rupture with North America. While "considerable remittances" in dollars arrived in Britain from Rio, gold was sent "chiefly to Pernambuco and Maranham."95 This information is reinforced by consular information from Robert Hesketh in

\footnotetext{
${ }^{90}$ Carlos Manuel Peláez and Wilson Suzigan, História monetária do Brasil (Brasília: Editora Universidade de Brasília, 1981), 46.

91 "Discurso Ministro Da Fazenda, Miguel Calmon Du Pin E Almeida," Diario de Pernambuco, April 25, 1829 , 89 edition, Memória Digital, Biblioteca Nacional.

92 Oliveira, Systema financial do Brasil, 59.

93 “Correspondencia, Mercator," Jornal Do Commercio, June 5, 1829, 490 edition, sec. Correspondencia, 1-2, Memória Digital, Biblioteca Nacional.

${ }^{94}$ Collecção Das Leis Do Imperio Do Brazil, Coleção Das Leis Do Império (1808 - 1889) (Rio de Janeiro: Typographia Nacional, 1878), bk. 1831 V.2 p.13; Oliveira, Systema financial do Brasil, 56-59.

${ }^{95}$ House of Commons, "Report Together with Minutes of Evidence, and Accounts, from the Select Committee on the High Price of Gold Bullion” June 8, 1810, 58-59, House of Commons Parliamentary Papers Online.
} 
1812 - right after the consul's arrival in Maranhão - reporting that the prices of British manufactures were "much lower" in Maranhão than in "ports to the southward" because of differences in the price of the precious metals. ${ }^{96}$ Hesketh noted again in 1830 that British imports in Maranhão were half the price of Rio de Janeiro due to differences in the exchange rate. ${ }^{97}$

In December of 1830, however, the British consul reported that the copper currency, "principally brought from Rio de Janeiro by the Brazilian packets" had nearly taken silver out of circulation in Maranhão. ${ }^{98}$ With the increasing coinage of copper in Rio de Janeiro and Bahia, copper coins began to replace gold and silver in Maranhão as early as $1825 .{ }^{99}$ Nevertheless, with the government's permission for copper and paper money to circulate in all provinces, 1830 marks a turning point for money markets between Rio de Janeiro and the northeast. ${ }^{100}$ The lift on the copper ban triggered a latent problem that was building up all over Brazil since the late 1820s: most taxes at custom-houses had to be paid in silver coins, and the increase in copper circulation raised the premium for silver. ${ }^{101}$ The problem was not restricted to the northeast provinces, and some exporters in Rio Grande do Sul requested to the central government in 1830 to pay their taxes using copper coins - an attempt blocked by the finance minister Marques de Barbacena. ${ }^{102}$ Chapter 5 will further discuss the effect of export taxes on cotton exports.

\subsection{Conclusions}

The new information presented in this chapter shows that the decline in Brazilian cotton exports was not related to a "Dutch disease" or it came from changes in British demand. Regarding declining prices after 1820, the United States, the East Indies, and Egypt faced the same price volatility as Brazil. But while the Brazilian cotton economy faced a crisis, other countries had continuous growth in their exports. Data from Liverpool's cotton market show that there are two crucial periods to understand the crisis in Brazilian cotton exports: the 1820s and the decade after 1837. Using information on production costs, the next chapter confirms

\footnotetext{
96 "FO 63/149 - Sir F. B. Hill, Consuls Robert Hesketh, A. Cunningham, Frederick Lindeman, and Various (Brazil)." 1813 1812, 72, The National Archives, Kew.

97 "FO 13/77 - Consuls Baldwin Sealy, Robert Hesketh, William Hesketh, John Hesketh, Foreign Various, and Consular Domestic.," 57.

${ }^{98}$ Ibid.

99 “Artigo Communicado,” Echo Do Norte, July 7, 1834, N.2 edition, 1, Memória Digital, Biblioteca Nacional.

100 Amaro Cavalcanti, O Meio Circulante Nacional : Resenha E Compilação Chronologica de Legislação E de Factos, vol. 1 (Rio de Janeiro: Imprensa Nacional, 1893), 177.

101 "Sobre O Discurso Do Eisel. Sr. Prezidente Thomaz Xavier Garsia de Almeida," Abelha Pernambucana, December 11, 1829, 67 edition, Memória Digital, Biblioteca Nacional.

${ }^{102}$ Collecção Das Leis Do Brazil de 1808 (Rio de Janeiro: Imprensa Nacional, 1891), bk. 1830 V.3 p.125.
} 
that the reduction in Liverpool's imports happened during periods of very low profitability for Brazilian cotton planters, suggesting that the decline in Brazilian cotton exports was related to supply factors, such as high production costs. The next two chapters also provide evidence for why there were no successful attempts to increase productivity of cotton plantations despite the continuous crisis in the sector. 


\section{The costs of cotton production in Maranhão}

Before the opening of the Brazilian ports to foreign trade, political and economic isolation narrowed the possibilities of economic advancement for planters in Brazil. The increase of foreign ships after 1808 brought not only more trade, but also information about international markets and foreign practices. ${ }^{1}$ Henry Koster, who witness firsthand the opening of Brazilian ports, argued that sugar planters in Pernambuco were extremely ignorant about international markets due to Portugal's control: with no contact with foreigners and no access to printed information, some planters though that sugar cane from Brazil had no significant foreign competitors at the time. Blinded by ignorance, planters continue year after year the same techniques their parents used, without incentives to improve. ${ }^{2}$ But after foreign traders began to arrive, Koster stated that some sugar-mill owners started to seek information respecting the management of the British and French plantations in the Columbian islands. ${ }^{3}$

The costs of colonial political institutions, nonetheless, were broader than poor information about foreign markets. ${ }^{4}$ In 1807, a judge from Bahia wrote that the absence of freedom for farmers "to employ workers and capital" in a manner that they seem fit, was the primary cause for the backwardness of agriculture development. Laws forced the cultivation of products with lower profits, endless permissions from men of power impaired the adoption of more modern technologies, making those "who should wield swords and quills to secure freedom, the tormentors who take it away." ${ }^{5}$ Henry Koster noted in 1810 that the "whole aspect of the government" in Brazil was military and that, in places like Maranhão, the governor ruled in the "most despotic way."

The Correio Braziliense, the only Brazilian newspaper at the time the royal family arrived, reported in 1810 that they received letters from Brazil (the newspaper was edited in

\footnotetext{
${ }^{1}$ On the exposures effects of trade, see Joel Mokyr, The Enlightened Economy: An Economic History of Britain 1700-1850 (New Haven: Yale University Press, 2012), 147.

${ }^{2}$ Koster, Travels in Brazil, 336.

3 Ibid., 337.

${ }^{4}$ On the effects of colonial political institutions, see Daron Acemoglu, Simon Johnson, and James A. Robinson, "The Colonial Origins of Comparative Development: An Empirical Investigation," American Economic Review 91, no. 5 (December 2001): 1369-1401, doi:10.1257/aer.91.5.1369; Nathan Nunn, "Historical Development," in Handbook of Economic Growth, ed. Philippe Aghion and Steven N. Durlauf, vol. 2, Handbook of Economic Growth (Elsevier, 2014), 347-402, http://www.sciencedirect.com/science/article/pii/B9780444535382000071. ${ }^{5}$ Governo do Estado da Bahia, Cartas Economico-politicas sobre a agricultura e commercio da Bahia pelo Desembargador João Rodrigues de Brito, Deputado das Côrtes; e outros. Dadas á luz por I. A. F. Benevides (Lisboa: Imprensa Nacional, 1924), 28-31.

${ }^{6}$ Koster, Travels in Brazil, 173; 190.
} 
London) complaining against local abuses by the government. According to the newspaper, one of the main problems faced by Portuguese colonies was the absence of accountability by people who had positions of power. The distance from Portugal, no freedom of press, and the lack of independent colonial councils, made it impossible to denounce the abuse of power by rulers. There was no mechanism that could serve to counterbalance the power of governors and, assured of their impunity, they "abuse their power; exercise it according to their whim, or for particular purposes; convert it into instrument of vengeance, or robbery, exceed the limits of legitimate authority, and even has come to impose taxes without the sovereign order." 7

The colonial legacy, therefore, left a series of bureaucratic structures that could not be changed overnight, creating unnecessary costs to trade. Several rules on how commerce should be conducted opened the possibility for rent-seeking behavior. For example, until 1831, a law that clearly increased costs to merchants required all national ships to have surgeons and chaplains on board: in one situation, the president of Maranhão held a vessel for more than a month because there was no chaplain that would go on board without the payment of one conto, almost the total freight cost of the ship. ${ }^{8}$ The Correio Braziliense bemoaned that such "violence" was possible to "the rights and property of individuals." During the 1820 s complaints about Brazil's military despotism and "tyrant governors" continued; even to lease parcels of land farmers required the goodwill of the province's president and the ministry of the empire. ${ }^{9}$

Reports like these attest the environment of political inequality and poor property rights that Brazil was left with after 1808. But in the case of cotton plantations, higher inequality could have benefited large landowners that had political power to demand lower production costs, such as improvements in transportation. ${ }^{10}$ High inland transport costs were a widespread problem for commercial activity in Brazil throughout the nineteenth century and have been considered one of the main factors that limited the expansion of cotton exports in the northeast. ${ }^{11}$ Before the age of railroads, roads and rivers were the only paths to reach areas away from the coast. In São Luís - the center of provincial government - travelers remarked that even in the

\footnotetext{
7 “Brazil Finanças," Correio Braziliense, 1810, 5 edition, sec. Miscellanea, 120-24, Memória Digital, Biblioteca Nacional.

${ }^{8}$ Collecção Das Leis Do Imperio Do Brazil, bk. 1831, v.1, p.7.

${ }^{9}$ Victor Nunes Leal, Coronelismo, enxada e voto, 7th ed. (São Paulo: Editora Companhia das Letras, 2012$), 143$.

${ }^{10}$ Daron Acemoglu et al., "Economic and Political Inequality in Development: The Case of Cundinamarca, Colombia," in Institutions and Economic Performance, ed. Elhanan Helpman (Cambridge: Harvard University Press, 2007), 181-245; Melissa Dell, “The Persistent Effects of Peru's Mining Mita," Econometrica 78, no. 6 (November 1, 2010): 1863-1903, doi:10.3982/ECTA8121.

${ }^{11}$ Leff, "Economic Development and Regional Inequality," 250; Stein, Origens e evolução da indústria têxtil no Brasil, 221.
} 
immediate vicinity of the city the roads were extremely deficient. ${ }^{12}$ Eduardo O. Machado, Maranhão's president in 1854, argued that a crucial problem for cotton plantations was that the province had no proper roads or river navigation. According to Machado, the price of transportation of various agricultural products ranged between 10 to 30 percent of their value, limiting the expansion of production inland..$^{13}$

The recognition of poor transport infrastructure by authorities, in conjunction with the fact that cotton planters had local political power, lead to the assumption that improvements in roads and river navigation would eventually be implemented as production expanded. Regions associated with cotton planting in Maranhão were centers of political power in the years after independence. For example, during the preparation for the first National Constituent Assembly - which would be dissolved in 1823 - several "head of districts" were selected across the country to facilitate the meeting of voters. In an official document with instructions for conducting the assembly, the districts selected in Maranhão were São Luís, Itapecuru Mirim, and Caxias. ${ }^{14}$ Moreover, several of the rich planters in the Itapecuru Mirim region lived in São Luís, which allowed them not only to obtain information on cotton markets, but also to pressure the government to enhance their economic situation..$^{15}$ This condition was similar to farmers in the United States, where Georgia's cotton planters also tended to settle in towns. ${ }^{16}$

Planters in Maranhão did not have poor political representation at the provincial level and this and the following chapter show that cotton exports generated considerable amounts of fiscal revenues during the early nineteenth century. ${ }^{17}$ These two conditions, therefore, increase the puzzle of why two of the most important infrastructure projects in Maranhão - a steamboat company and a canal - failed to be implemented after broad recognition of their importance. Improvements also did not come at a significant rate for other cotton regions in the northeast,

\footnotetext{
12 Koster, Travels in Brazil, 176.

13 Assembleia Legislativa Provincial, "Relatorio Do Presidente Da Provincia Do Maranhão, O Doutor Eduardo Olimpio Machado, Na Abertura Da Assembléa Legislativa Provincial No Dia 3 de Maio de 1854, Acompanhado Do Orçamento Da Receita E Despeza Para O Anno de 1855." (Maranhão, 1854), Center for Research Libraries, Global Resources Network, http://www-apps.crl.edu/brazil/provincial/maranhão.

14 "From H. Chamberlain (Brazil), FO 63/246" September 1822, 122, The National Archives, Kew.

${ }^{15}$ Bernardo Jose da Gama, Informação sobre a capitania de Maranhão, dada em 1813 ao chanceller Antonio Rodrigues Velloso, (Vienna d'Áustria: Impr. do filho de C. Gerold, 1872), 10; Antonia da Silva Mota, As Famílias Principais Redes de Poder No Maranhão Colonial (São Luís: EDUFMA, 2012), 85.

${ }^{16}$ Joseph Patrick Reidy, From Slavery to Agrarian Capitalism in the Cotton Plantation South: Central Georgia, 1800-1880 (Chapel Hill: University of North Carolina Press, 1992), 35.

${ }^{17}$ For the impact of poor political representation and long-run economic growth, see Miriam Bruhn and Francisco A. Gallego, "Good, Bad, and Ugly Colonial Activities: Do They Matter for Economic Development?," The Review of Economics and Statistics 94, no. 2 (July 19, 2011): 433-61, doi:10.1162/REST_a_00218.
} 
and at times small improvements like cleaning rivers were only possible with donations from local individuals. ${ }^{18}$

To address these questions, this chapter first shows how cotton plantations expanded geographically in Maranhão during the first half of the nineteenth century. Section 4.2 presents the fiscal resources available for investments in infrastructure and argues that political centralization, in which Rio de Janeiro set limitations for local fiscal management, inhibited investments in infrastructure in Maranhão. The final section estimates the production costs for cotton planters in Maranhão. Consistent with information on international cotton prices, the 1820s and the decade after 1837 brought lower profitability for cotton planters in Maranhão.

\subsection{The location of cotton plantations in Maranhão.}

Cotton planting in Maranhão began in the regions of Alcântara and Guimarães, west of São Luís, and then expanded along the Itapecuru river up to Caxias. ${ }^{19}$ Alcântara produced high quality, long-stapled cotton and Henry Koster reported that the region was a thriving place in the 1810 s, with a great demand for lands. ${ }^{20}$ Other travelers from the early nineteenth century noted that cotton plantations in Alcântara used the "black seed" variety, which was probably the same as the Sea Island in the U.S.. ${ }^{21}$ According to Jerônimo de Viveiros, there were three kinds of short staple cotton in Maranhão: common, herbaceous, and another called "algoduí."22 The first one had better quality and market value; its fiber was tougher and longer, and the plant could give harvest three years in a row. The second, introduced in 1788, had a shorter and less resistant fiber than common cotton. The last one, "the algoduí," was a yellow cotton and was not cultivated extensively. This classification shows that, like what happened in the United States, as plantations moved inland staples became shorter with the use of seeds more appropriate to terrains distant from the coast. Inland expansion, however, did not halt production in the older areas; reports of cotton plantations near Alcântara continued in the following decades. ${ }^{23}$

\footnotetext{
${ }^{18}$ Evaldo Cabral de Mello, A outra independência: o federalismo pernambucano de 1817 a 1824 (Editora 34, 2004), 30 .

${ }^{19}$ For a broad description about the settlement of the regions in Maranhão, see Manuel Correia de Oliveira Andrade, Nordeste, espaço e tempo, Caminhos Brasileiros (Editōra Vozes, 1970).

${ }^{20}$ Koster, Travels in Brazil, 179.

21 "O Algodão," 202.

22 Viveiros, História do comércio do Maranhão, 1954, 1:112.

${ }^{23}$ Manoel José d'Oliveira Bastos, "Roteiro Das Capitanias Do Pará E Maranhão, Piauhy, Pernambuco E Bahia, Pelos Seus Caminhos E Rios Centraes - 1819," Revista Trimestral Do Instituto Histórico E Geográfico

Brasileiro, 1846, Tomo VII-Segunda Edição edition, 531.
} 


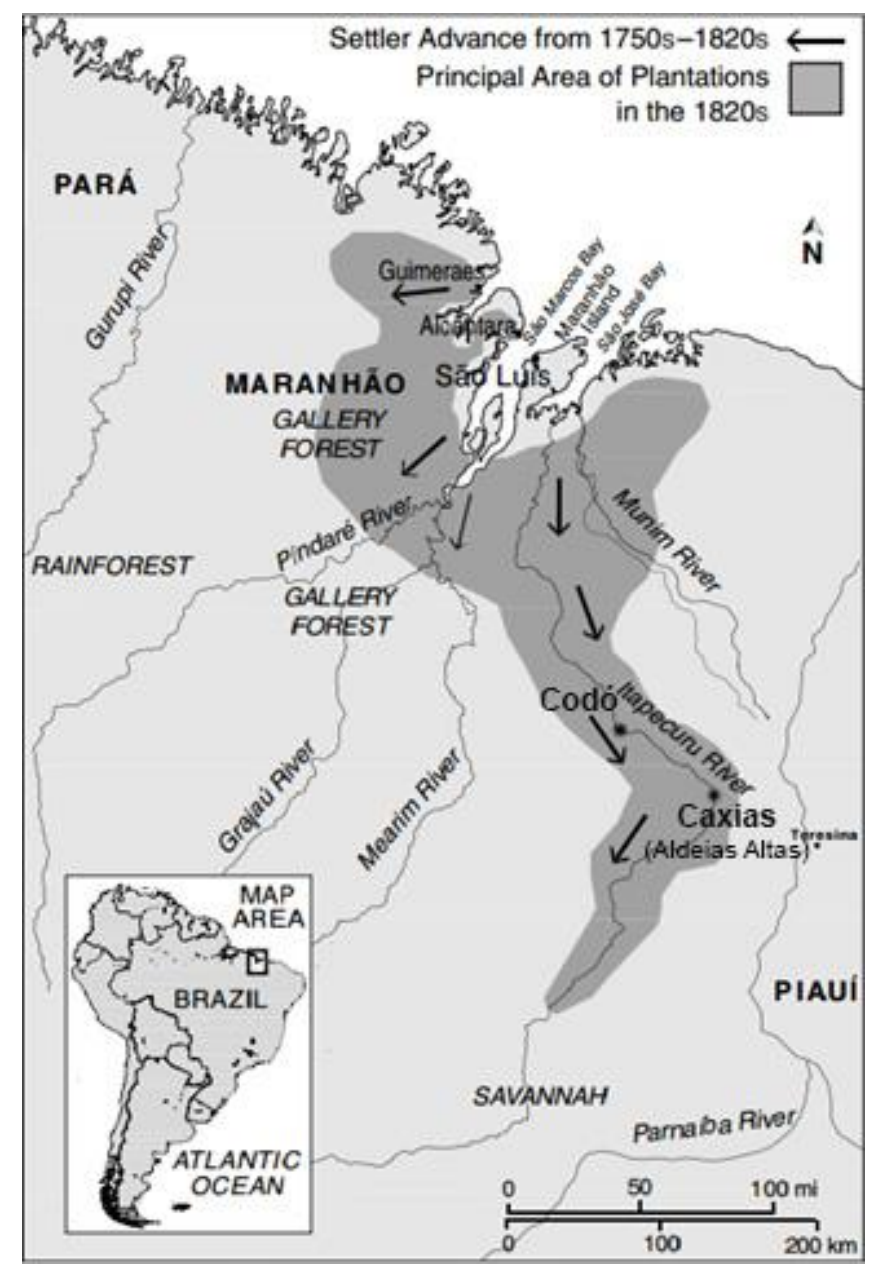

Figure 4.1 - Maranhão occupation, 1750s - 1820s

Source: Walter Hawthorne. From Africa to Brazil: culture, identity, and an Atlantic slave trade, 1600-1830, 2010, p.xxi.

Despite some geographic diversification in cotton planting, "the land par excellence" in Maranhão was the region near Codó, in the Itapecuru river (see Figure 4.1). ${ }^{24}$ Reports during the 1810s stated that the banks along the river were "yet very wild" and there was "incalculable" space for new colonists. ${ }^{25}$ A cotton planter wrote that after São Luís, Alcântara and "Ribeira do Itapecuru" were the most important places in the province in the $1810 \mathrm{~s}$, with the latter populated by a "multitude of farmers." ${ }^{26}$ Statistics on agricultural production at Ribeira between 1801 and 1805 show that cotton and rice were by far the most important products. Almost all the production of cotton was transported to São Luís (98 percent), from which 64 percent was exported abroad - as Brazilian ports were still not open to foreign trade, all exports initially went to Lisbon. Since cotton can be warehoused, it is not clear that all the difference between

\footnotetext{
${ }^{24}$ Viveiros, História do comércio do Maranhão, 1954, 1:112.

${ }^{25}$ Koster, Travels in Brazil, 183.

${ }^{26}$ Gayoso, Compendio Historico-Politico Dos Principios Da Lavoura Do Maranhão, 113, 163.
} 
what arrived and was exported in São Luís in those years was consumed locally. Part of the cotton was probably used in coarse fabrics, both for clothing and furnishing. ${ }^{27}$ Moreover, Manuel Camara wrote in 1799 that one fourth of the raw cotton produced in Brazil, especially in remote areas, was for medicinal use, such as balm for wounds. ${ }^{28}$ Regarding other products, rice, hides, and flour were also mostly exported to São Luís, while coffee and rubber were used for local consumption. During the first decade of the nineteenth century, the Ribeira had a population of 13,397 people, with 329 farmers and 11,327 slaves, giving an average of 34.4 slaves per farmer. ${ }^{29}$ Using a population map from 1798, the region represented 16 percent of Maranhão's total population and 27 percent of slaves - for the entire province the total number of farmers was 3,146, with an average of 11.24 slaves per farmer. During the 1830s, the upper parts of the Itapecuru river still accounted for two-thirds of cotton and rice production in the province. $^{30}$

Some regions west of the Itapecuru river had potential as an agricultural frontier, but planters initially were reluctant to move to those areas because of large indigenous populations. A newspaper article from 1822 discussed the problem of a "high number of gentiles that occupied the best lands in the Province." While Indians were scattered across different regions, such as Pastos Bons and Alto Itapecuru - both south of Caxias - the article addressed the central-west region of Viana, Monção, and Mearim, and advocated the "removal of Indians," so that agriculture expansion could be made in a "safe way" for farmers. There were 5,000 people in Mearim, among them 2,000 slaves, cultivating sugar cane, bananas, oranges, and some coffee. The terrain in that region was not suitable to grow cotton, but the cultivation took place in some farms north of the village of Vitória, capital of the Mearim district. According to the newspaper, the terrain in that area was as good as in Codó, "until today known for having the best lands for cotton cultivation." ${ }^{31}$

Reports from Caxias, which produced rice and cotton, also stated that planters during the early 1820 s could not expand production because of the indigenous population. ${ }^{32}$ Being in

\footnotetext{
${ }^{27}$ Michael M. Edwards, The Growth of the British Cotton Trade, 1780-1815 (Manchester University Press, 1967), 34.

${ }^{28}$ Manuel Arruda da Camara, Memoria Sobre a Cultura Dos Algodoeiros E Sobre O Methodo de O Escolher, E Ensacar (Lisboa: Officina da Casa Litteraria, 1799), 12.

${ }^{29}$ 6,309 men and 5,018 women. Gayoso, Compendio Historico-Politico Dos Principios Da Lavoura Do Maranhão, 164.

30 “Sr. Redator (Cartas)," O Publicador Official, May 10, 1834, 260 edition, 1073, Memória Digital, Biblioteca Nacional.

31 “L'Esperance Console de Tous Les Maux," Conciliador Do Maranhão, June 19, 1822, 98 edition, 5-6.

32 "Memoria Sobre a Decadencia Da Lavoura E Outros Ramos de Prosperidade Publica No Destricto de Aldeas Altas Que Percizão Ser Providenciados.," Conciliador Do Maranhão, March 2, 1822, 67 edition, 4.
} 
clear disagreement with the violent policies of Andrew Jackson in the U.S. South to remove the indigenous population, the testimonies from Maranhão suggest the weak role the Brazilian government had in supporting the expansion of the agriculture frontier. ${ }^{33}$ Differently from the United States, cotton planters in Brazil did not have clear expectations of the actions that the government would take to support them. For example, the central government waged war against indigenous population in Minas Gerais some years before, but in Caxias - despite government's promises - planters were left on their own to dispute the territories with the indigenous population. ${ }^{34}$

Table 4.1 - Number of cotton bags produced in Maranhão by location, 1853-58

\begin{tabular}{lrrrrrr}
\hline & $1853-54$ & $1854-55$ & $1855-56$ & $1856-57$ & $1857-58$ & $\begin{array}{c}\text { Exports 1852 } \\
\text { (mil-réis })\end{array}$ \\
\hline Alcântara & 2,877 & 2,894 & 1,649 & 3,415 & 2,633 & 232,875 \\
Anajatuba & & 63 & 14 & 5 & 4 & \\
Caxias & 18,973 & 20,382 & 15,464 & 15,908 & 14,558 & 595,983 \\
Guimarães & 840 & 5,097 & 1,132 & 602 & 1,367 & 251,774 \\
Itapecuru & 19,883 & 15,898 & 10,998 & 17,199 & 12,474 & 727,958 \\
Mearim & 7,120 & 5,542 & 5,998 & 6,150 & 3,267 & 265,143 \\
Munin & 1,091 & 1,106 & 928 & 878 & 1,590 & 143,938 \\
Pindaré & 4 & 21 & 49 & 11 & 6 & 154,762 \\
Turiaçú & 610 & 1,218 & 1,140 & 1,202 & 1,449 & 55,809 \\
Tutória & & 4 & & 3 & & 3,260 \\
Viana & 1,211 & 1,087 & 964 & 1,703 & 1,255 & 152,310 \\
\hline Total & 52,619 & 53,312 & 38,339 & 47,076 & 38,603 & \\
\hline
\end{tabular}

Sources: Mesquita, Vida e morte da economia algodoeira, 88; Provincial Presidential Reports Maranhão 1853, 34.

The limited expansion of cotton plantations in the following decades appears in Table 4.1, showing Maranhão's cotton production in the 1850s. The region around Itapecuru-Mirim remained an important area, but contemporary reports argued that some farms were disappearing due to the "lack of arms and land exhaustion." Meanwhile, Caxias continued as the cotton frontier: government reports stated that despite its fertile land, with several cotton farms and four "modern" sugar mills, Caxias still had large a stretch of its territory "abandoned

\footnotetext{
${ }^{33}$ Daniel Walker Howe, What Hath God Wrought: The Transformation of America, 1815-1848 (New York: Oxford University Press, 2007), 347.

${ }^{34}$ Judy Bieber, “'The Brazilian Rhône': Economic Development of the Doce River Basin in Nineteenth-Century Brazil, 1819-49'," Journal of Latin American Studies 48, no. 1 (February 2016): 10, doi:10.1017/S0022216X15000851.
} 
and uncultivated." ${ }^{35}$ Therefore, after decades of growing demand for cotton in international markets, locations of cotton plantations in Maranhão did not change significantly for almost five decades: Ribeira and Caxias still represented 70 percent of Maranhão's cotton production in the 1850s. As argued before, one reason for why cotton did not expand to new areas could have been due to higher transport costs as production moved further inland. The next section discusses important attempts to improve transportation in the province.

\subsection{Fiscal centralization and investments in transportation}

As plantations expanded inland, transportation costs became a potential problem not only for staple crops, but also to market integration. Without steamboats, the journey between São Luís to Caxias took around eight days in a small canoe, which was the fastest way upstream. ${ }^{36}$ The Itapecuru river was not an easy river to navigate because currents changed rapidly in different seasons, especially in the winter. ${ }^{37}$ Defective roads and strong rains made travel in some parts of the province possible only between October and January. ${ }^{38}$ Given such constraints, it should not come as a surprise that there was awareness that investment in transport infrastructure was vital. A recurrent argument in Maranhão's Presidential Reports was that capital employed in canals and roads produced "wealth and civilization," and outweighed "all sacrifices." 39

The lack of investments to improve transportation and provide other public goods was initially related to the limitation of regional governments in deciding their own budget. Before the 1830s there was no clear rule on how revenues should be divided between the central government and provinces. ${ }^{40}$ The major source of revenue for provinces - since colonial times - was the dízimo, which was divided between local administrations and the Portuguese government. The dízimo, however, was not initially a good source of revenue because it was

\footnotetext{
35 "Relatorio Do Presidente Da Provincia Do Maranhão, O Doutor Eduardo Olimpio Machado, Na Abertura Da Assembléa Legislativa Provincial" (Maranhão, 1853), 34, Center for Research Libraries, Global Resources Network, http://brazil.crl.edu/bsd/bsd/351/.

${ }^{36}$ José Pedro Cesar Menezes, "Roteiro Para Seguir a Melhor Estrada Do Maranhão Para a Côrte Do Rio de Janeiro," Revista Do IHGB Tomo III (1841): 512.

${ }^{37}$ Bastos, "Roteiro Das Capitanias Do Pará E Maranhão, Piauhy, Pernambuco E Bahia, Pelos Seus Caminhos E Rios Centraes - 1819," 532-33.

${ }^{38}$ Antônio Bernardino Pereira do Lago, "Itinerário Da Província Do Maranhão," Revista Do IHGB Tomo XXXV (1872): 402.

39 "Falla Que Recitou O Exm. Presidente E Commandante Das Armas Da Provincia Do Maranhão, O Coronel Luiz Alves de Lima, N'abertura Da Assemblea Legislativa Provincial" (Maranhão, 1840), 17, Center for Research Libraries, Global Resources Network, http://brazil.crl.edu/bsd/bsd/339/.

${ }^{40}$ Sturz, A Review Financial, Statistical and Commercial of the Empire of Brazil and Its Resources; Together with a Suggestion of the Expediency and Mode of Admitting Brazilian and Other Foreign Sugars Into Great Britain, 15.
} 
hard to collect. Before 1821, there were two ways to charge the dizimo. The first method was through collecting houses distributed in parishes near plantation zones. Given Brazil's size, it was an expensive and inefficient because it required a multitude of public employees. The second method was even more problematic: it involved collectors (dizimeiros) who "harassed poor planters [and forced them] to fraudulent or excessive transactions;" bringing the planters to local judges if they refused to comply with the extortion. ${ }^{41}$ Enforcement problems led the government to change the law in 1821, collecting all taxes related to exports at ports. Another important change to limit abuses by local officials was that the dizimo began to be based on weekly market prices after $1825 .{ }^{42}$

Table 4.2 - Maranhão revenues from cotton exports, 1816-1852

\begin{tabular}{cccc}
\hline Year & Revenue from “dízimo" & Tax Rate & Average Price (mil-réis) \\
\hline 1816 & $230,128 \$ 518$ & $8 \%$ & 6,500 \\
1817 & $238,272 \$ 293$ & $8.5 \%$ & 8,500 \\
1818 & $232,276 \$ 225$ & $8.5 \%$ & 8,000 \\
1819 & $167,137 \$ 455$ & $8.5 \%$ & 8,050 \\
1820 & $127,355 \$ 528$ & $7.5 \%$ & 5,150 \\
1821 & $66,012 \$ 342$ & $7 \%$ & 4,075 \\
1837 & $125,677 \$ 816$ & $6 \%$ & 7,760 \\
1838 & $106,359 \$ 460$ & $5 \%$ & 7,235 \\
1839 & $83,400 \$ 206$ & & 6,700 \\
1840 & $80,117 \$ 919$ & & 6,622 \\
1841 & $75,546 \$ 136$ & & 5,933 \\
1842 & $56,018 \$ 122$ & & 5,300 \\
1844 & $63,715 \$ 510$ & $3 \%$ & 5,000 \\
1845 & $36,262 \$ 401$ & & 4,900 \\
1846 & $39,955 \$ 207$ & & 5,270 \\
1847 & $42,579 \$ 513$ & $5 \%$ & 6,660 \\
\hline 1851 & $111,450 \$ 776$ & & \\
1852 & $54,791 \$ 772$ & & \\
\hline
\end{tabular}

Sources: Lago, Estatística histórico-geográfica; Provincial Presidential Reports - Maranhão 18371855; Viveiros, História do comércio do Maranhão. Vol. 2, 323.

Table 4.2 shows that, with high international cotton prices during the 1810 s, the dizimo generated substantial revenues. These resources could have been used to improve public infrastructure, especially when prices fell during the 1820s and planters needed to reduce transportation costs to maintain profit rates. But despite these incentives, the decades before 1850 had no successful improvements in river transportation.

\footnotetext{
${ }^{41}$ Coleção Das Leis Do Brazil (1821 - 1825) (Rio de Janeiro: Typographia Nacional, 1889), bk. 1821 v.2 p.65.

${ }^{42}$ Coleção de Decretos, Cartas Imperiais E Alvar[as Do Império Do Brazil, Coleção Das Leis Do Império (1808

- 1889) (Rio de Janeiro: Typographia Nacional, 1885), bk. 1825 v.1 p;59.
} 
The difficulty of moving agricultural products to ports - either through land or river is one of the reasons why the extension of riverways in the United States has always been stressed by Brazilian scholars. ${ }^{43}$ As cotton production in the United States moved southwest, the area around the Mississippi valley saw a rapid growth in steamers' traffic, with steamers carrying more freight than railroads in the U.S. South between 1820 and $1860 .{ }^{44}$ There were twenty-one steamboats carrying 70,000 tons of freight to New Orleans in 1813, and the number of boats increased to 198 in $1820 .{ }^{45}$ Flatboats, however, were still responsible for most of the traffic in the Mississippi River during the 1810s. ${ }^{46}$ Broadhorns and other flatboats held around thirty tons of cargo, resembling the barges in Maranhão "of about 25 or 30 tons' burthen" that flowed downstream with cotton and rice to São Luís. ${ }^{47}$ From Alcântara, lighter canoes, which could carry up to fifty bags ( 4 tons) of cotton, transported most of the produce to São Luís. ${ }^{48}$

The increasing number of steamboats in the 1810s, which could carry between 300 and 400 tons, represented a major increase in transport efficiency in the United States. Steamboats also carried products upstream, a limitation for flatboats. To increase Maranhão's exports, therefore, the government and local planters would have to eventually improve the infrastructure to move cotton to São Luís. After all, the government recognized that insufficient means of transportation paralyzed the "immense resources of the cotton industry," and that rivers, "which in every sense cut the province," were vital for the expansion of trade. ${ }^{49}$

Despite the existence of steamboat navigation in Bahia since 1819, the first talks about a steam navigation company in Maranhão began only in the $1830 \mathrm{~s} .{ }^{50}$ Projections stated that the use of small steamboats could double profits for farmers along the Itapecuru river. ${ }^{51}$ The government passed the first law for steamboat navigation in 1837, but the Balaiada revolt delayed implementation for three years..$^{52}$ In addition, demands from the provincial government

\footnotetext{
${ }^{43}$ Clodomir Vianna Moog, Bandeirantes e pioneiros : paralelo entre duas culturas (Rio de Janeiro : Editôra Globo, 1957), 27.

${ }^{44}$ Robert Gudmestad, Steamboats and the Rise of the Cotton Kingdom (Baton Rouge: Louisiana State University Press, 2011), 6.

${ }^{45}$ Walter Johnson, River of Dark Dreams (Cambridge: Harvard University Press, 2013), 256.

${ }^{46}$ Gudmestad, Steamboats and the Rise of the Cotton Kingdom, 10.

${ }^{47}$ Koster, Travels in Brazil, 171.

${ }^{48}$ Lago, "Itinerário Da Província Do Maranhão," 402.

49 "Discurso Que Recitou O Exm. Snr. Manoel Felisardo de Sousa E Mello, Presidente Desta Provincia, Na Occazião Da Abertura Da Assemblea Legislativa Provincial” (Maranhão, May 3, 1839), 61, Center for Research Libraries, Global Resources Network, http://brazil.crl.edu/bsd/bsd/338/.

${ }^{50}$ Governo do Estado da Bahia, Cartas Economico-politicas sobre a agricultura e commercio da Bahia pelo Desembargador João Rodrigues de Brito, Deputado das Côrtes; e outros. Dadas á luz por I. A. F. Benevides (Lisboa: Imprensa Nacional, 1924), 16.

51 “Sr. Redator (Cartas)," 1073.

52 Viveiros, História do comércio do Maranhão, 1954, 1:255.
} 
- such as free transport for public employees and official mail, and the exemption of charges for all produce up to 25 arrobas - raised investment costs and drove away potential investors to the company. ${ }^{53}$ Steamboat navigation in Maranhão at that time followed a national pattern of failed attempts to implement similar projects across Brazil during the 1830s. ${ }^{54}$

In 1840, Maranhão’s government increased monopoly rights to 20 years for anyone who wanted to implement steam navigation in the Itapecuru, with a premium for building the boats in the province. With no bidder for the project, the situation remained the same until 1849, when a local businessman started a company to operate a small steamboat with 40 horsepower, less than half the horsepower used to transport cotton to New Orleans in $1816 .{ }^{55}$ The problem was that the steamboat, built in Britain, was too large for some parts of the river, and could not reach Caxias - the final stop - during the inaugural trip. ${ }^{56}$ Two years later the company, which had a monopoly to transport goods in the river, went bankrupt.

The failure of the steamboat company was a symptom of a larger problem that affected cotton production in Brazil during the 1840s: low profitability (see Figure 4.2). With low international prices during the 1840s, larger infrastructure improvements were essential to keep cotton production profitable. But with limited capacity to increase revenues, crucial improvements in infrastructure that the local government wanted to do depended on the stamp of politicians in Rio de Janeiro. Resources for any project, which had to be included in the province's budget, had to be approved by the senate, creating delays and uncertainty. In 1832, a political debate on whether the senate should have accepted a lower house's request to finish a bridge in São Luís, to improve access to the custom-house, shows how difficult was the situation. ${ }^{57}$ Senator Almeida e Silva, from Maranhão, argued that the province did not have the resources to finish the project, which was essential to improve commerce and navigation in the region. After a long discussion, however, the Senate did not accept the request because it did not fulfill all the necessary bureaucratic procedures, leaving a relatively simple project stalled.

\footnotetext{
${ }^{53}$ Provincial Law N.42 - August 3, 1837.

${ }^{54}$ Vitor Marcos Gregório, “O Progresso a Vapor: Navegação E Desenvolvimento Na Amazônia Do Século XIX," Nova Economia 19, no. 1 (April 2009): 185-212, doi:10.1590/S0103-63512009000100008; Bieber, “"The Brazilian Rhône."”

${ }^{55}$ Charles R. Morris, The Dawn of Innovation: The First American Industrial Revolution (New York: PublicAffairs, 2012), 176; "Falla Dirigida Pelo Exm. Presidente Da Provincia Do Maranhão, Honorio Pereira de Azeredo Coutinho, Á Assembléa Legislativa Provincial” (Maranhão, 1850), Center for Research Libraries, Global Resources Network, http://brazil.crl.edu/bsd/bsd/348/.

56 “Notícias Maranhão," Publicador Maranhense, July 13, 1851, 1133 edition, 4, Memória Digital, Biblioteca Nacional.

57 “Sessão Ordinaria Em 2 de Junho de 1832,” Diario Da Camara Dos Senadores, 1832, 25 edition, 3, Memória Digital, Biblioteca Nacional.
} 
These examples show that fiscal and political centralization created considerable transaction costs to finance public goods..$^{58}$ Like many other countries during the nineteenth century, the central government in Brazil used its revenues primarily to finance wars and service debts. ${ }^{59}$ Europe and the United States were no different, but both regions left the responsibility of infrastructural works to local governments or the private sector. ${ }^{60}$ As will be discussed in the next chapter, with no political power to set fiscal revenues, provinces in Brazil could only ask - and wait - for more resources and complain about the central government's lack of virtue in the application of public resources. Statements in newspapers denouncing the expansion of the public sector, with the central government "filling Brazil with public employees and [only] promoting the army" were not unusual. ${ }^{61}$ However, these criticisms were not directed at the public sector as a whole, but to a policy that removed funds from provincial governments. Without the possibility to raise revenues through import duties, export taxes still accounted for more than a third of total revenues for provinces during the $1850 \mathrm{~s} .{ }^{62}$ Several decades after, in 1875, Maranhão's newspapers reported that the competition for resources remained unchanged.: "the [central] government has wrongly marched concerning the application of public funds, having no qualms about spending it in such a superfluous manner on what is not first needed." ${ }^{63}$

Perhaps no other example is as illustrative to show that the failure to implement important infrastructure projects was not related to fiscal capacity than the history of the "furo," a canal that was intended to facilitate access to the port of São Luís. São Luís, Maranhão's capital, is surrounded by two bays: São José in the east and São Marcos in the west (see Figure 4.1). During the early years of cotton production, most economic activity happened at the west bay because plantations were located at the coastal region of Alcântara and Guimarães. ${ }^{64}$ Commerce began to grow on the east bay when cotton production moved inland along the Itapecuru river. The problem was that, while the west bay was considered safe for ships, the

\footnotetext{
${ }^{58}$ Guy Michaels, “The Long Term Consequences of Resource-Based Specialization,” The Economic Journal 121, no. 551 (March 1, 2011): 31-57, doi:10.1111/j.1468-0297.2010.02402.x.

${ }^{59}$ William R. Summerhill, Inglorious Revolution: Political Institutions, Sovereign Debt, and Financial Underdevelopment in Imperial Brazil (New Haven: Yale University Press, 2015).

${ }^{60}$ Dan Bogart et al., "State and Private Institutions," in The Cambridge Economic History of Modern Europe: Volume 1, 1700-1870, ed. Stephen Broadberry and Kevin H. O’Rourke (Cambridge: Cambridge University Press, 2010), 82.

61 “Tráfico de Escravos," Farol Marenhense, January 5, 1830.

62 "Relatorio Do Presidente Da Provincia Do Maranhão, O Doutor Eduardo Olimpio Machado, Na Abertura Da Assembléa Legislativa Provincial."

63 “Porque Soffre a Lavoura No Brazil," Diario Do Maranhão, January 28, 1875, 445 edition, 1, Memória Digital, Biblioteca Nacional.

${ }^{64}$ Koster, Travels in Brazil, 179.
} 
east bay was dangerous for navigation due to its irregular depth. ${ }^{65}$ When the British consul Robert Hesketh arrived in Maranhão in 1812, one of his first remarks mentioned the perils of strong currents and low sandy shores at the bay of São José ${ }^{66}$ Since the port of São Luís is located on the west bay, the transportation of products from inland arrived at the east bay and had to be transported overland to São Luís. Therefore, the idea to build a canal to connect the city of São Luís to the Itapecuru River became a recurrent topic in public debate, with the government and planters recognizing its construction as of the utmost importance.

Initially idealized during the government of João de Abreu Castelo Branco in the early 1740s, the first real measure to build the canal came with the taxation of cotton exports in 1776 . Before this date, cotton exports were too small to justify any large investment. To finance its construction, the government charged 160 réis for each arroba of cotton exported ${ }^{67}$ After the payment of customs, the money was taken to the local Senate's town hall and placed in a safe called "do furo." In 1792 (carta régia de 27 de junho), the safe was transferred to the imperial treasure in Rio de Janeiro, which collected the tax until 1808. From 1776 until 1808, the tax generated $624,463 \$ 533$, a considerable sum above what was initially estimated to build the canal. ${ }^{68}$

After the arrival of the Portuguese royal family, however, the money was transferred to the national treasury in 1808, leaving the government (and cotton farmers) in Maranhão with no resources to build the canal. ${ }^{69}$ It took almost twenty years for the imperial government to recognize that Maranhão needed to get at least part of the money back to improve access to its port. ${ }^{70}$ The project reappeared in 1827 , when the central government proposed a bill to "open the canal, a long-time project to facilitate trade between the capital city and the interior of the province of Maranhão." The bill proposed to use part of the revenue from the tax of 600 réis for each arroba of cotton exported to finance the project. Three years later, however, the government terminated the export tax and new measures had to be taken: the central

\footnotetext{
${ }^{65}$ Lago, "Itinerário Da Província Do Maranhão,” 385.

66 "FO 63/149 - Sir F. B. Hill, Consuls Robert Hesketh, A. Cunningham, Frederick Lindeman, and Various (Brazil).," 69.

67 “Discurso Que Recitou O Exm. Snr. Manoel Felisardo de Sousa E Mello, Presidente Desta Provincia, Na Occazião Da Abertura Da Assemblea Legislativa Provincial," 63.

68 “Relatório Da Província Do Maranhão 1852” (Maranhão, 1852), 38, Center for Research Libraries, Global Resources Network, http://brazil.crl.edu/bsd/bsd/u322/.

69 "Falla Com Que O Exm. Sr. Dr. Cincinnato Pinto Da Silva, Presidente Da Provincia, Installou a 2.a Sessão Ordinaria Da 23.a Legislatura Provincial Do Maranhão Em 19 de Fevereiro de 1881. Maranhão, 1881." (Maranhão, February 19, 1881), 94, Center for Research Libraries, Global Resources Network, http://brazil.crl.edu/bsd/bsd/385/index.html.

${ }^{70}$ Annaes do Império 28 sep 1827 p.79 / (11 de out 1827)
} 
government offered the annual amount of 24 contos to finance the canal. ${ }^{71}$ Despite these promises from the central government, the project remained stalled until 1848, when construction started again with an estimated cost of 103 contos. ${ }^{72}$ Maranhão's president declared at that time that "for almost a century the government recognizes the great advantages to facilitate navigation to the province's interior.". ${ }^{73}$ Four years later, with half the canal unfinished, 192 contos had already been spent and, in 1853, the new budged estimated costs at 346 contos. $^{74}$ Finally, in 1858 , with expenses higher than 600 contos and no conclusion in sight, the government decided to abandon the project. $^{75}$

The canal was the largest project in the province until that point, with an estimated length of 4,893 meters and employing up to 400 people. However, the canal was relatively small for international standards and its failure was in part due to typical problems of moral hazard. According to Viveiros, with financing by the imperial government, laborers received wages well above market levels and the project became a "factory of jobs" exploited by political parties. ${ }^{76}$ Moreover, uncertainty over the continuity of resources throughout the project created delays and additional costs for cotton production in Maranhão. In 1854, the responsible for canal's construction showed that, between 1830 and 1853, shipwrecks that occurred because there was no direct connection between the Itapecuru river and the port amounted to a loss to the province of 749 contos. In addition to reduce freight costs, he showed that the construction would increase government income by 12 contos, given the proposed tax of 20 réis for each arroba transported through the canal. ${ }^{77}$

\subsection{Production costs on Maranhão's cotton plantations}

Descriptions of the profitability of cotton plantations around 1800 suggest similarities across the Americas, with cotton acreage yielding equivalent production in the United States, the West Indies, and Brazil. ${ }^{78}$ During the first decade of the nineteenth century, plantation

\footnotetext{
${ }^{71}$ Cartas de Lei de 27 de agosto de 1830, 15 de dezembro de 1830, 15 de novembro de 1831, 4 de Outubro de 1832,8 de outubro de 1833 .

72 "Relatório Da Província Do Maranhão 1852," 38

73 “Maranhão (Provincia) Presidente (Franco de SA)" (Maranhão, May 3, 1847), 50, Center for Research Libraries, Global Resources Network, http://brazil.crl.edu/bsd/bsd/345/.

74 “Relatorio Do Presidente Da Provincia Do Maranhão, O Doutor Eduardo Olimpio Machado, Na Abertura Da Assembléa Legislativa Provincial," 22.

75 “Relatorio 1858” (Maranhão, 1858), 14, Center for Research Libraries, Global Resources Network, http://brazil.crl.edu/bsd/bsd/u328/.

76 Viveiros, História do comércio do Maranhão, 1954, 1:225.

${ }^{77}$ See http://brazil.crl.edu/bsd/bsd/385/000098.html

${ }^{78}$ Bryan Edwards, The History, Civil and Commercial, of the British West Indies, 5th ed., vol. 2 (London: G. and W.B. Whittaker, 1819), 319; John Hebron Moore, The Emergence of the Cotton Kingdom in the Old Southwest:
} 
expenses in Guyana before shipment were $7 \mathrm{~d}$ per $\mathrm{lb}$. of cotton, and $6 \mathrm{~d}$ for North American planters. ${ }^{79}$ Crops in Demerara also cost $7 \mathrm{~d}$ per lb. to raise in $1815 .{ }^{80}$ Records show that each working hand in South Carolina produced between $£ 45$ (U\$215) and $£ 85$ (U\$350) of Sea Island cotton, while in the hinterland (sertão) region of Brazil a slave produced $£ 70$ (250\$000) of short staple cotton, which had lower prices. ${ }^{81}$ For long staple cotton, Tollenare argued in 1816 that despite the difficulty in obtaining detailed information, it was reasonable to assume that each slave picked around 600 pounds of cleaned cotton. ${ }^{82}$ This amount was comparable to that picked in South Carolina, where each slave produced 1,000 pounds of short staple cotton, or 600 of long staple. In Cayenne, another producer of long staple, production amounted to 600 pounds for each slave as well. ${ }^{83}$

Other reports broaden the range of productivity between Brazil and the United States, but do not present large differences. Records from a Louisiana plantation in 1817 show that slaves picked between 500 and 800 pounds of seed cotton in a harvesting season. ${ }^{84}$ Daily averages ranged from 45 to 67 pounds of seed cotton, while in Brazil the amount was between 32 and 65 pounds. ${ }^{85}$ During the 1790s, Manuel Camara wrote that on his Paraíba farm a slave could easily prepare 1,065 pounds of seed cotton, which meant around 272 pounds of cleaned cotton. ${ }^{86}$ Raimundo Gayoso, a planter in the largest cotton region in Maranhão, documented in 1813 that on an average cotton plantation a slave prepared 1,280 pounds of cotton (384 pounds cleaned) ${ }^{87}$

\footnotetext{
Mississippi, 1770-1860 (LSU Press, 1988), 132; Camara, Memoria Sobre a Cultura Dos Algodoeiros E Sobre O Methodo de O Escolher, E Ensacar.

${ }^{79}$ Charles Mackenzie, Facts, Relative to the Present State of the British Cotton Colonies: And to the Connection of Their Interests with Those of the Mother Country (Edinburgh: T. Bryce \& Co, 1811), 21, http://uclibs.org/PID/126171.

${ }^{80}$ Treasure Department, Letter from the Secretary of the Treasury, Transmitting Tables and Notes on the Cultivation, Manufacture, and Foreign Trade of Cotton. (Washington, D.C.: Gales \& Sraton, 1836), 33, http://hdl.handle.net/2027/uc1.\$b674462.

${ }^{81}$ Ulrich Bonnell Phillips and John David Smith, Life and Labor in the Old South (Columbia, S.C: University of South Carolina Press, 2007), 93; T. B. Thorpe, "Sea Island Cotton," Harper's New Monthly Magazine, April 17, 1869; José de Sá Bettencourt, Memoria sobre a plantação dos algodões, : e sua exportação; sobre a decadencia de lavoura de mandiocas, no termo da villa de Camamú, comarca dos Ilhéos, governo da Bahia, appresentada, e offerecida a sua alteza real o Principe do Brazil nosso senhor, ([Lisbon] : Na officina de Simão Thaddeo Ferreira., 1798), 34.

${ }^{82}$ Tollenare, Notas dominicaes tomadas durante uma residencia em Portugal e no Brasil nos annos 1816, 1817 e $1818,118$.

${ }^{83}$ Ibid., 115. Cotton presses had prices up to 25 contos.

${ }^{84}$ Moore, The Emergence of the Cotton Kingdom in the Old Southwest, 9.

${ }^{85}$ Edwards, The History, Civil and Commercial, of the British West Indies, 2:313; "O Algodão," 205.

${ }^{86}$ Camara, Memoria Sobre a Cultura Dos Algodoeiros E Sobre O Methodo de O Escolher, E Ensacar, 35.

${ }^{87}$ Gayoso, Compendio Historico-Politico Dos Principios Da Lavoura Do Maranhão, 264.
} 
Even with differences in ginning technology - Maranhão used only roller gins before 1830 - the ratio between seed and cleaned cotton was also similar. An advertisement for the famous Whitney cotton gin in 1794 stated that five pounds of seed cotton yielded approximately one and one half pounds of fiber. ${ }^{88}$ While older varieties of cotton yielded lint-to-seed ratios of 0.25 , the new varieties at the beginning of the nineteenth century yielded ratios of up to 0.33 , close to the ratio observed in Maranhão. ${ }^{89}$ Before the 1820 s, even if slaves could cultivate more cotton, picking capacity was the main constraint to the amount produced in the United States. ${ }^{90}$ In Maranhão, there is also evidence that farmers could not take full advantage of "superabundant crops" because slaves could only "pick between 32 and 64 pounds a day."91

Biological improvements after the 1820s reduced picking restrictions in the United States, and the average daily upland cotton picking rate increased fourfold between 1801 and $1862 .{ }^{92}$ In the new cotton states slaves managed to pick 200 to 300 pounds per day when the plants were fully mature, in late summer. ${ }^{93}$ In 1834 , slaves could already produce 2,000 pounds of cleaned cotton. ${ }^{94}$ This was considerably higher than reports from Brazil: a manual for farmers in the northeast stated that during the 1830s, each slave could produce 640 pounds of cleaned cotton (probably short-stapled) ${ }^{95}$ The growth in productivity through several decades widened output differences between the United States and other producing countries prior to the 1861 Civil War. In the preface of a translated version of A. Turner's "The Cotton Planter's Manual" (distributed in Maranhão two years after its release) a comparison between cotton production in Brazil and the United States shows that the same area in the U.S. cotton south produced five times more cotton than in Maranhão in $1857 .{ }^{96}$ In Maranhão, within an area of 484 square meters (quadra de cem braças), a laborer could produce on average 960 pounds of seed cotton,

\footnotetext{
${ }^{88}$ Lakwete, Inventing the Cotton Gin, 57.

${ }^{89}$ Alan L. Olmstead and Paul W. Rhode, "Biological Innovation and Productivity Growth in the Antebellum Cotton Economy," The Journal of Economic History 68, no. 04 (December 2008): 1133, doi:10.1017/S0022050708000831.

${ }^{90}$ Ibid., 1142.

91 “O Algodão," 205.

92 Olmstead and Rhode, "Biological Innovation and Productivity Growth in the Antebellum Cotton Economy," 1150.

${ }^{93}$ Karen Gerhardt Britton, Bale O' Cotton: The Mechanical Art of Cotton Ginning (Texas A\&M University Press, 1992), 24.

94 Treasure Department, Letter from the Secretary of the Treasury, Transmitting Tables and Notes on the Cultivation, Manufacture, and Foreign Trade of Cotton. (Washington, D.C.: Gales \& Sraton, 1836), 20.

${ }_{95}$ Carlos Augusto Taunay and L. Riedel, Manual do Agricultor Brazileiro, 2nd ed. (Rio de Janeiro: Typographia Imperial, 1839), 44.

96 A. Turner, Manual Do Plantador D’algodão, (Maranhão: Officina Typographica do Frias, 1859), http://hdl.handle.net/2027/coo.31924016403341.
} 
while in the United States the same area produced 4,800 pounds. ${ }^{97}$ In addition, each worker with the plowing system was able to work in more than one area, increasing output differences even more. ${ }^{98}$

Even with the substantial productivity divergence with the United States, it is difficult to agree with the view put forward by some authors that productivity in Brazilian cotton plantations did not increase during the nineteenth century. ${ }^{99}$ In fact, there is evidence of technology adoption already in the 1790s, with improved cotton gins and presses used to prepare the cotton bags in the Paraiba region, then part of Pernambuco. ${ }^{100}$ A planter from one of the richest families in Maranhão brought from Portugal in 1799 plows and reapers to produce rice and cotton and stated that cotton output tripled with the new tools. ${ }^{101}$ In the same way, the use of different ginning machines during the early nineteenth century suggests that a lack of capital or technological know-how can hardly be considered a central explanatory variable for the persistent differences in productivity. ${ }^{102}$ There is ample evidence of the use of roller gins to process long-staple cotton in the northeast during the 1830s. ${ }^{103}$ Similarly, saw-gins were implemented in Maranhão in the 1830s to increase productivity on plantations that used shortstaple seeds from the United States. ${ }^{104}$ Moreover, for the United States, Olmstead and Rodhe argued that one of the "neglected signs" of productivity growth in cotton plantations was that output expanded faster than the workforce during the antebellum period, and slaves' real prices increased at a time when real cotton prices were falling. ${ }^{105}$ That was the case in Maranhão between 1800 and 1820, when cotton exports grew by 3.8 percent per annum while the slave population, with increasing prices, expanded by 3.5 percent.

\footnotetext{
97 "Relatorio Do Presidente Da Provincia Do Maranhão, O Doutor João Lustosa Da Cunha Paranaguá, Na Abertura Da Assembléa Legislativa Provincial No Dia 3 de Maio de 1859" (Maranhão, 1859), 29, Center for Research Libraries, Global Resources Network, http://brazil.crl.edu/bsd/bsd/358/.

${ }^{98}$ Slaves' picking capacity per acre is a limited measure of productivity, since slaves managed to work in multiple fields. See Gavin Wright, "River of Dark Dreams: Slavery and Empire in the Cotton Kingdom," Journal of Economic Literature 52, no. 3 (September 1, 2014): 877-79, doi:10.1257/jel.52.3.851.r16.

${ }^{99}$ Mesquita, Vida e morte da economia algodoeira do Maranhão, 71.

${ }^{100}$ Camara, Memoria Sobre a Cultura Dos Algodoeiros E Sobre O Methodo de O Escolher, E Ensacar, 73.

101 "Memoria Do Lavrador José Joaquim Vieira Belford," Conciliador Do Maranhão, March 2, 1822,67 edition, 3.

${ }^{102}$ For a theoretical discussion, see Joseph E. Stiglitz, "Rational Peasants, Efficient Institutions, and a Theory of Rural Organization: Methodological Remarks for Development Economics," in The Economic Theory of Agrarian Institutions, by Pranab K. Bardhan (Oxford: Clarendon Press, 1991), 18.

103 Taunay and Riedel, Manual do Agricultor Brazileiro, 43.

104 Mesquita, Vida e morte da economia algodoeira do Maranhão, 113.

${ }^{105}$ Olmstead and Rhode, "Biological Innovation and Productivity Growth in the Antebellum Cotton Economy," 1127.
} 
Except for Rui de Albuquerque, who estimated the profitability of cotton plantations in Maranhão between 1812 and 1821, there is no quantitative information for production costs and their relation to international cotton prices for Brazil. ${ }^{106}$ Low prices are not relevant for explaining the stagnation of cotton exports in the existence of high productivity growth or the decline in prices of other relevant input factors. Therefore, some baseline information is necessary to estimate how price variations pressured profits and might have affected cotton planters in Maranhão. The most detailed information on cotton production in Maranhão for the early nineteenth century is provided by Gayoso. Table 4.3 presents his calculation of "all expenditures for a cotton plantation" in the 1810s after the end of the harvest and processing period, but before the payment of taxes. ${ }^{107}$ The freight cost is the average of what was charged in the cotton region of Codó - located in the Itapecuru river - to the port of São Luís. Each slave generally had a cost of 200 réis per day, but as they also worked on others crops for their own needs, food costs were taken out. ${ }^{108}$ The total cost of cleaned cotton in Maranhão around 1813 was estimated at $3 \$ 279$ per arroba, out of which 91 percent consisted of labor costs. Other authors suggested that with additional costs, such as commissions and insurance, costs reached up to $4 \$ 000$, a value comparable to reports concerning cotton production in Bahia. ${ }^{109}$

Table 4.3 - Cotton production costs in Maranhão $c .1813$

\begin{tabular}{lrc}
\hline $\begin{array}{l}50 \text { slaves, } 300 \text { days of work, 120 réis per slave per } \\
\text { day }\end{array}$ & $1.800 \$ 000$ & $£ 642,85$ \\
$\begin{array}{l}\text { Freight of } 109 \text { bags (600 arrobas of clean cotton), } \\
465 \text { réis each }\end{array}$ & $50 \$ 685$ & $£ 18,10$ \\
$\begin{array}{l}\text { 3.5 varas of coarse cottons for each bag (4 rolls, } \\
18 \$ 000 \text { each) }\end{array}$ & $72 \$ 000$ & $£ 25.71$ \\
2 rolls of coarse cotton to dress the slaves & $45 \$ 000$ & $£ 16,07$ \\
Total & $1.967 \$ 685$ & $£ 702.74$ \\
Cost to produce an arroba (32 lb.) of cotton & $3 \$ 279$ & $8.64 \mathrm{~d} .(1 \mathrm{lb})$. \\
\hline
\end{tabular}

Source: Gayoso, Compendio Historico-Politico, 264.

To calculate productivity changes, presented in the equation below, the baseline is Gayoso's figures that each slave produced 384 pounds of cleaned cotton by 1813, as well as the estimate that there was a productivity gap with the United States of about five times in 1859 . To estimate the potential of productivity increases in Maranhão, it is possible to combine the latter information with Olmstead and Rhode's result that cotton picking increased 2.3 percent per annum between 1800 and 1862. These conditions (see Table A5 in the appendix) yield a

\footnotetext{
${ }^{106}$ Albuquerque, Capital comercial, indústria têxtil e produção agrícola, 70.

107 Gayoso, Compendio Historico-Politico Dos Principios Da Lavoura Do Maranhão, 264.

${ }^{108}$ Slaves didn't work on Sundays.

109 “O Algodão,” 206.
} 
0.25 percent annual growth for slave productivity in Maranhão. Just as in the United States, slaves were a major input in Brazil's cotton plantations and, therefore, price changes in the labor force had a significant impact on production costs. ${ }^{110}$ In addition to slave prices, the calculation considers changes in the size of cotton bags across time, freight prices, and variations in cotton prices on the cost of each bag and slave clothing. ${ }^{111}$

$$
\text { Cost }_{\text {pence per } l b .}=\frac{\text { Slave Price }+ \text { Freight }+ \text { Cost of Bag }+ \text { Cost Slave Clothing }}{\text { Slave Productivity }}
$$

Some caveats should be acknowledged here: as mentioned before, productivity growth in Maranhão was not constant across six decades, and it was probably higher before 1820 (and cotton plantations in the 1850s were already in a deep crisis). Gayoso's productivity estimation is lower than other reports at the time and must be taken as a conservative baseline. Moreover, Olmstead and Rhode's result of an increase of 2.3 percent in picking is their upper bound estimation, which accounts for the best seed in the best land. With these limitations in mind, Figure 4.2 presents the estimated costs along with cotton prices in the ports of São Luís and Liverpool. In addition, there is also a counterfactual price for São Luís without export taxes, which will be discussed in detail in the next chapter. Reports from the British consul in Maranhão during the 1820 s attest that planters payed duties on their produce "in kind on all articles except cotton," which duty was deducted from the "amount by the purchasers, and they pay it into the treasury." ${ }^{112}$ As economic theory would predict, the imposition of export taxes reduced domestic prices and, therefore, the counterfactual price is the observed price at the port plus the tax rate.

The cost for cotton plantations in Maranhão is consistent with international comparisons. While the cost in Maranhão was 5.7d. on average during the 1830s, in Mississippi and Alabama a value of $4 \mathrm{~d}$. "would pay expenses" for a pound of cleaned cotton around $1830 .{ }^{113}$ In the Southwestern states, 5d. per pound was regarded as a profitable crop. According to

\footnotetext{
${ }^{110}$ Slave prices will be presented in Chapter 5. For the United States, see Olmstead and Rhode, "Biological Innovation and Productivity Growth in the Antebellum Cotton Economy," 1127.

${ }^{111}$ Freights for 1854, see Mesquita, Vida e morte da economia algodoeira do Maranhão, 204. The amount that each cotton bag carried increased on average 0.27 percent annually between 1809 and 1860 .

112 "FO 13/12 - Lord A. Marcus C. Hill, Consuls John Parkinson and Robert Hesketh.," 204.

113 Treasure Department, Letter from the Secretary of the Treasury, Transmitting Tables and Notes on the Cultivation, Manufacture, and Foreign Trade of Cotton., 28.
} 
Edward Baines, planters in the Mississippi valley could make a profit with prices as low as $3 \mathrm{~d}$. in 1833 , indicating the higher productivity of the new cotton areas in the United States. ${ }^{114}$

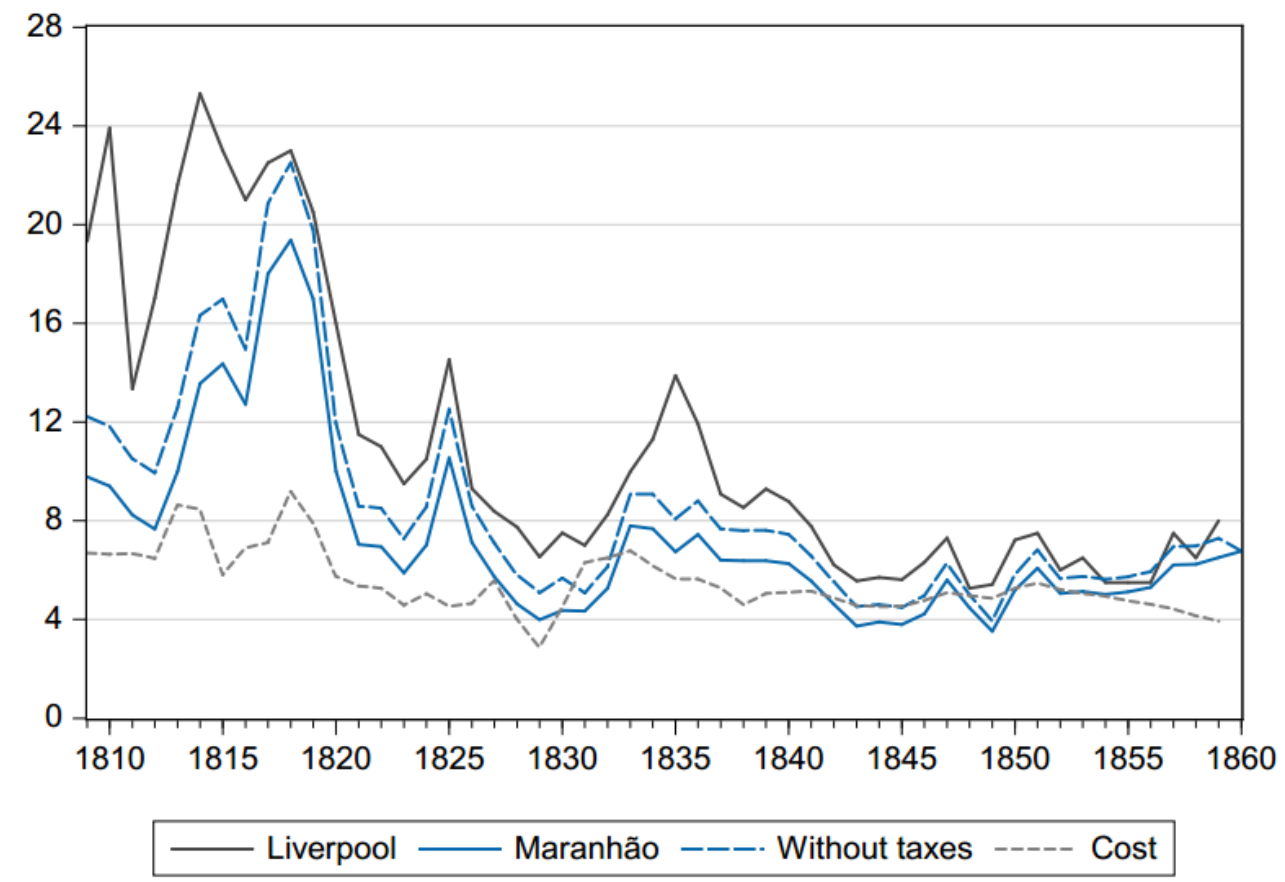

Figure 4.2 - Prices of Maranhão cotton and production cost, 1809-1860

Sources: Prices in Liverpool - Liverpool Mercury; prices in Maranhão - Lago, Estatística históricogeográfica, Soares, "BRAZIL: Report. Cultivation of Cotton"; Cost - Gayoso, Compendio HistoricoPolitico. See Table A5 in the appendix.

Even without a precise estimate, the cost presented above for Maranhão shows that lower international prices during the 1840 s represented periods with lower profits (prices minus costs). During the 1820s, however, a higher profit margin could have been appropriated by planters if the government had not imposed prohibitive export taxes. Lower prices during the 1820s stimulated the search for productivity increases in the United States, with seed experimentation and the use of steamboats to lower production costs. ${ }^{115}$ At the same time, the government of Maranhão recognized that the province missed the opportunity to improve cotton production during the period of higher demand by British textile factories after the end of the Napoleonic Wars. ${ }^{116}$

Another indication of low profitability in cotton exports during the 1820s is that some foreign commercial houses left Maranhão at the time. In a list of "British subjects" resident in Maranhão in 1826, there were only ten merchants organized in seven separate merchant houses,

\footnotetext{
${ }^{114}$ Edward Baines, History of the Cotton Manufacture in Great Britain (R. Fisher and P. Jackson, 1835), 316.

115 Moore, The Emergence of the Cotton Kingdom in the Old Southwest; Gudmestad, Steamboats and the Rise of the Cotton Kingdom.

${ }^{116}$ Relatório Presidencial da Província do Maranhão, 1848, p. 32.
} 
almost half the number from the previous decade. ${ }^{117}$ This was remarkable because British merchants had almost no competition in Maranhão. The British consul in Maranhão reported that between 1818 to 1820 there was some Portuguese investment in the trade to Great Britain, but it was gradually receding and British capital "would eventually" face no competition from "either the National, French, or American capitals." 118

Table 4.4 - Cotton Production and its relationship with slave population (million pounds)

\begin{tabular}{lcrrrccc}
\hline & 1801 & 1811 & 1821 & 1839 & $\mathrm{Q} / \mathrm{L} 1801$ & $\mathrm{Q} / \mathrm{L} 1821$ & $\mathrm{Q} / \mathrm{L} 1838$ \\
\hline South Carolina & 20.0 & 40.0 & 50.0 & 61.7 & 137 & 193 & 189 \\
Georgia & 10.0 & 20.0 & 45.0 & 163.4 & 168 & 301 & 582 \\
Alabama & & & 20.0 & 117.1 & & 478 & 462 \\
Mississippi & & & 10.0 & 193.2 & & 305 & 990 \\
Louisiana & & & 10.0 & 153.9 & & 145 & 914 \\
Maranhão & 6.7 & 9.9 & 10.0 & 7.7 & 161 & 127 & 69 \\
Pernambuco & 6.6 & 9.5 & 10.0 & 8.8 & & & \\
\hline
\end{tabular}

Sources: Bruchey, Cotton and the Growth of the American Economy; Soares, "BRAZIL: Report. Cultivation of Cotton," 1861 (FO 881/1003).

Table 4.4 presents information of cotton production in Brazil and the United States, with the three last columns showing the ratio between cotton production and the number of slaves in the population. Even if it is not possible to infer productivity differences from aggregate data, the widening gap in cotton production after 1820 is staggering. Between 1820 and 1840, Maranhão still had a slave population share comparable to Mississippi and Louisiana, and higher than Alabama and Georgia. ${ }^{119}$ Therefore, the decay of Brazilian cotton production was not related to an insufficient labor supply, but to differences in labor productivity.

The difference in the amount of cotton produced by a slave in the U.S. South compared to Brazil was noticeable to contemporaries during the mid-nineteenth century. During a debate in 1850 over the Lei de Terras, a Senator from Maranhão stated that low productivity explained the poor state of the cotton trade in his home province. According to the Senator, the culture's "desperate situation" had one main cause: "the amount of work of one slave in the United States is equivalent to thirty slaves in Brazil." ${ }^{120}$ Even with the Senator's probable exaggeration, low productivity growth is the overall explanation for why Brazilian cotton decreased its share in the British market.

\footnotetext{
117 “FO 13/30 - Arthur Aston, Consuls John Parkinson and Robert Hesketh.," 208.

118 "FO 63/240 Consuls' Office” (Maranham, May 20, 1821), 201, FO 63/240, British National Archives.

119 The statistics on slavery and cotton plantations in Brazil will be discussed in Chapter 5.

${ }^{120}$ Anais Do Senado Do Império Do Brasil. 1823-1888 (Brasília: Senado Federal - Subsecretaria de Anais, 1978), Sessões de Julho de 1850, livro 5, 396.
} 


\subsection{Conclusions}

With low prices during the 1840s, the president of Maranhão lamented that the province, "which so prospered by the wealth of agricultural products, has fallen in decay due to lower cotton prices in the market, which as is known, is our most important crop."121 The decline of Brazilian cotton plantations, however, had already started decades before the 1840s. During the first decades of the nineteenth century, cotton plantations in Maranhão faced several economic and political difficulties. The increasing demand from Britain meant that plantations had to move further inland, increasing transport costs. This condition, however, was hardly unique, and the period witnessed a surge in investments to improve roads and river navigation in Europe and the United States. ${ }^{122}$ High production costs and declining prices could have been overcome with productivity growth.

The evidence that there were some attempts to improve cotton production raise the question why technology adoption was not widespread across the northeast. One possible explanation was the existence of economic or political barriers to the implementation of reforms. Contemporary evidence suggests that technology adoption not only depends on traditional factors such as income per capita, human capital, and openness to trade, but also depends on political institutions. ${ }^{123}$ In regions with political regimes that are not sufficiently democratic, opposition to technology adoption increases when groups with political power can be hurt by technological innovation, a result that also finds evidence in the support for trade liberalization. ${ }^{124}$ For Maranhão, however, these barriers do not seem to have existed, since there was no clear interest group that would have the incentive to block improvements in cotton production and support trade restrictions. ${ }^{125}$ The next chapter, therefore, will discuss a central cause for low productivity growth in Brazilian cotton plantations: high export taxes that reduced profit margins to cotton planters. Fiscal policy dictated by Rio de Janeiro redirected large amounts of provincial revenue to the central government, inhibiting local investments.

\footnotetext{
121 "Falla Que Recitou O Presidente Da Provincia Do Maranhão, Antonio Joaquim Alvares Do Amaral, Na Abertura Da Assembléa Da Mesma Provincia Em 28 de Julho de 1848.” (Maranhão, 1848), 32, Center for Research Libraries, Global Resources Network, http://brazil.crl.edu/bsd/bsd/346/.

${ }^{122}$ Bogart et al., "State and Private Institutions," 88.

${ }^{123}$ D. Comin and B. Hobijn, "Cross-Country Technology Adoption: Making the Theories Face the Facts," Journal of Monetary Economics 51, no. 1 (January 1, 2004): 39-83, doi:10.1016/j.jmoneco.2003.07.003.

${ }^{124}$ Diego Puga and Daniel Trefler, "International Trade and Institutional Change: Medieval Venice's Response to Globalization," The Quarterly Journal of Economics 129, no. 2 (May 1, 2014): 753-821, doi:10.1093/qje/qju006.

${ }^{125}$ Mota, As Famílias Principais Redes de Poder No Maranhão Colonial.
} 
Moreover, provinces could not collect resources from imports and depended on additional export taxes - especially the dízimo - to maintain local public administration. ${ }^{126}$

${ }^{126}$ Leal, Coronelismo, enxada e voto, 142. 


\section{Taxation and the stagnation of cotton exports, $1800-1860$}

There are two striking facts that arise with the sudden stagnation of Brazilian cotton exports during the 1820s, after Maranhão and Pernambuco had continuous export growth for more than three decades. The first one was that Brazil was the only major exporter where the stagnation happened - the United States, East Indies, and Egypt expanded their exports to Britain continuously between 1820 and $1860 .{ }^{1}$ The second was how fast it all happened: almost immediately after Britain returned to the gold standard, Brazilian exports stopped increasing. These two facts suggest that the stagnation was not related to external shocks, but to some endogenous process.

Robert Hesketh, the first British consul in Maranhão, provided in 1821 a possible explanation to both facts: planters had lower profits even during periods with high international prices. Hesketh was also a cotton trader and his reports to the British Foreign Office had detailed descriptions of market conditions. He reported that despite "very profitable prices" during the seven years prior to 1821 , and "overflowing quantity of capital in the market," planters did not improve their economic situation and all that remained from the cotton boom years were debts with slave dealers. ${ }^{2}$ The consul noticed in the following year that the "chief part of all the taxes and duties" fell on the planters, and "so long as this system is acted upon, there appears little chance of any steady advance in their wealth." 3

Hesketh was not alone in his remarks on the impact of export taxes on agricultural production. Raimundo Gayoso, an important cotton planter in Maranhão, worried in the 1810s that constant increases in taxation, contrary to "trade practices of the civilized world," would ruin the country's agricultural exports. ${ }^{4}$ In 1823, right after independence, José Caetano Gomes, treasury secretary of Rio de Janeiro, advocated the abolition of all export taxes: "It is a tribute established against all principles of political economy, in which the most enlightened nations, knowing their true interests, do not have; on the contrary, they encourage exports with prizes." Criticism of the cost of export taxes to agriculture was an issue debated since colonial times,

\footnotetext{
${ }^{1}$ Gavin Wright, "The Efficiency of Slavery: Another Interpretation," The American Economic Review 69, no. 1 (1979): 225; Nicholas F. R. Crafts, "The First Industrial Revolution: A Guided Tour for Growth Economists," The American Economic Review 86, no. 2 (1996): 197-201.

2 "FO 63/240 - Consuls Alexander Cunningham, William Pennell, Robert Hesketh, John Lempriere, Cox, and John Parkinson, Etc. (Brazil).” 1821, 203, The National Archives, Kew.

3 "FO 63/249 - Consuls Alexander Cunningham, Robert Hesketh, and William Pennell, Etc. (Brazil)." 1822, 74, The National Archives, Kew.

${ }^{4}$ Gayoso, Compendio Historico-Politico Dos Principios Da Lavoura Do Maranhão, 284.

${ }^{5}$ Augusto Olympio Viveiros de Castro, "Historia Tributaria Do Brasil," Revista Trimestral Do Instituto

Histórico E Geográfico Brasileiro LXXVIII, no. Parte 1 (1916): 34.
} 
but it increased when the government expanded taxation after 1808 to support the new political structure that Brazil now required as center of the Portuguese Empire.

Much like other regions in the Americas during the early nineteenth century, custom revenues dominated government resources in Brazil. ${ }^{6}$ With no incentives to tax imports from Portugal, however, and no other source to rapidly increase its revenues, the government pushed the fiscal burden to the two main export products: sugar and cotton. ${ }^{7}$ In 1808 , when cotton taxes increased, the United States Embargo and the war with Britain (in 1812) presented a favorable environment for Brazilian producers, from which the Portuguese government thought it was possible to pass the tariff cost to foreign consumers. The Portuguese government assumption, however, was not totally unfounded at the time. Even before the arrival of the royal family, Lord Strangford - then British ambassador to Portugal - suggested in 1807 a remodeled Methuen Treaty whereby Portugal was to admit English cotton manufactures at preferable rates while England was to be given preference to Portuguese raw cotton from Brazil. ${ }^{8}$ Yet with the normalization of international commerce after 1815 it became clear that Brazil could not affect international prices and the tax burden would inevitably fall on the domestic planters. ${ }^{9}$

The increased capacity of the Portuguese government to "meddle in provincial affairs" after 1808 , especially in fiscal issues, is recognized by the literature. ${ }^{10}$ The violent federalist claims in Pernambuco, between 1817 and 1824, are largely associated with the "fiscal voracity" of Rio de Janeiro, and contemporaries noted the weight of the royal court on provincial budgets. ${ }^{11}$ Henry Koster wrote in the 1810 s with a hint of indignation that citizens in Recife, whilst living in total darkness, had to pay a tax for lighting the streets of Rio de Janeiro. ${ }^{12}$ Also, there were four different taxes in Pernambuco for staple crops, including contributions created to finance the Dutch war during the seventeenth century. In 1816, when cotton prices were at their highest, Pernambuco transferred 32 percent of its revenues to Rio de Janeiro. ${ }^{13}$ In Maranhão, withdrawals from the provincial treasury supported the police in Rio de Janeiro and

\footnotetext{
${ }^{6}$ John Joseph Wallis, "The National Era," in Government and the American Economy: A New History, ed. Price V. Fishback (Chicago: University of Chicago Press, 2008), 151.

${ }^{7}$ Mello, A outra independência, 29.

${ }^{8}$ Manchester, British Preeminence in Brazil, 59.

${ }^{9}$ An analysis of a similar effect of taxation on export staples is Vito Tanzi, "Export Taxation in Developing Countries: Taxation of Coffee in Haiti," Social and Economic Studies 25, no. 1 (1976): 70.

${ }^{10}$ Roderick Barman, Brazil: The Forging of a Nation, 1798-1852 (Stanford University Press, 1994), 47.

${ }^{11}$ Mello, A outra independência, 30.

${ }^{12}$ Koster, Travels in Brazil, 32.

${ }^{13}$ Peter L. Eisenberg, The Sugar Industry in Pernambuco: Modernization Without Change, 1840-1910

(University of California Press, 1974), 30.
} 
the creation of the Bank of Brazil, leaving the local government with limited resources. ${ }^{14}$ After Brazil's independence, Maranhão initially remained loyal to Portugal because opponents to the government argued that the only connection the province had with Rio de Janeiro was with "its treasury." 15

During the 1820s, therefore, political dissatisfaction with the fiscal policies from Rio de Janeiro grew as prices in European markets declined. In 1830, when cotton prices at Brazilian ports achieved very low levels, newspapers reported that the fiscal regime made cotton production unprofitable "everywhere," and changes had to be made to help northern provinces, "so oppressed by government abuses and public unrest." ${ }^{16}$ Senator Nicolau Vergueiro publicly argued in 1830 that the Brazilian tax system hindered exports and was the "cause of misery among people." ${ }^{\prime 17}$ In a debate on the effects of taxes on cotton production at the Chamber of Deputies, Carneiro da Cunha (from Paraíba) complained about the "perverse destiny" of northern provinces given that they had to contribute more than southern provinces to the imperial treasury. Cunha argued that if the central government did not reduce its taxation on cotton production, the culture would cease to exist. ${ }^{18}$

Newspapers front-pages also criticized the fiscal policy of the imperial government throughout the nineteenth century because Brazil was "one of the rare countries" that taxed exports. ${ }^{19}$ The Aurora Fluminence, for example, addressing the issue of how the government should pay its debts during the 1820s, pointed at the negative incentives of tax exports on cotton production. ${ }^{20}$ A letter from Pernambuco published by the newspaper stated that the government should had rejected the use of loans and new taxes to reduce its debt because there was already in place "immense" taxation that "numbed the industry." The alternative was to replace charges on production for a consumption tax, since additional taxation on production would "depopulate

\footnotetext{
${ }^{14}$ Viveiros, História do comércio do Maranhão, 1954, 1:139.

${ }^{15}$ Luís Antônio Vieira da Silva, História da independência da Província do Maranhão, 1822-1828 (Rio de Janeiro: Companhía Editôra Americana, 1862), 49.

16 "Rio de Janeiro," A Aurora Fluminense, August 23, 1830, 378 edition, sec. Interior, Memória Digital, Biblioteca Nacional.

${ }^{17}$ Anais Do Senado Do Império Do Brasil. 1823-1888, bk. 1830 (3) p.587.

${ }^{18}$ Annaes do Parlamento Brazileiro, Camara Dos Srs. Deputados, 1830, vol. 2 (Rio de Janeiro: Typographia de H. J. Pinto, 1878), 154.

19 “Os Direitos de Exportação,” Diario Do Maranhão, July 22, 1874, 290 edition, 1, Memória Digital, Biblioteca Nacional.

${ }^{20}$ Thomas Flory, Judge and Jury in Imperial Brazil, 1808-1871: Social Control and Political Stability in the New State (University of Texas Press, 2015).
} 
cities of the Brazilian Empire the same way as the tax on cotton depopulates the hinterland (sertões) of Pernambuco.”21

Despite such dramatic statements from numerous sources, there is still little quantitative evidence to measure the impact of Brazilian fiscal policies on nineteenth century trade. The decades around independence are considered one of the most under-research periods in Latin American history and, in the case of Brazil, provincial trade and fiscal data before 1840 are limited, especially for regions outside Rio de Janeiro. ${ }^{22}$ This chapter, therefore, presents new fiscal data for Maranhão from provincial reports and the collection of Brazilian laws between 1808 and 1850. Section 4.1 addresses the effects of Rio de Janeiro's fiscal policies on the northeast's cotton stagnation. It shows that the largest fiscal burden on local governments during the cotton boom period was the transfer of revenues to Rio de Janeiro. The fiscal policy set by the Portuguese government after 1808 not only increased production costs for planters but also diverted resources that could have been used to increase productivity and expand production. $^{23}$

Tax systems are recognized as important institutions for long-run growth but our understanding of their impact on specific development circumstances is limited. ${ }^{24}$ The recent literature on state capacity argues that centralized states that managed to develop a system to collect taxes had an important role on the development of modern growth during the nineteenth century. ${ }^{25}$ State capacity, however, also presupposes the existence of political institutions that can enforce law and order while also putting constraints on the executive, something that several regions in Latin America lacked during the early nineteenth century. ${ }^{26}$ Without political constraint in the central government fiscal centralization can result in a level of taxation that is detrimental to economic growth in regions that do not have proper representation at the central

\footnotetext{
21 “Correspondência," A Aurora Fluminense, August 26, 1829, 231 edition, sec. Variedades, 4, Memória Digital, Biblioteca Nacional.

${ }^{22}$ Rory Miller, Britain and Latin America in the Nineteenth and Twentieth Centuries, 1 edition (London; New York: Routledge, 1995), 71; Bertola and Ocampo, The Economic Development of Latin America since Independence, 54.

${ }^{23}$ Robert E. Hall and Charles I. Jones, "Why Do Some Countries Produce So Much More Output Per Worker than Others?," The Quarterly Journal of Economics 114, no. 1 (February 1, 1999): 83-116, doi:10.1162/003355399555954.

${ }^{24}$ Sokoloff and Zolt, "Inequality and the Evolution of Institutions of Taxation: Evidence from the Economic History of the Americas."

${ }^{25}$ Noel D. Johnson and Mark Koyama, "States and Economic Growth: Capacity and Constraints," Explorations in Economic History, 2017, doi:10.1016/j.eeh.2016.11.002; Mark Dincecco and Gabriel Katz, "State Capacity and Long-Run Economic Performance," The Economic Journal 126, no. 590 (February 1, 2016): 189-218, doi:10.1111/ecoj.12161; Timothy Besley and Torsten Persson, Pillars of Prosperity: The Political Economics of Development Clusters (Princeton University Press, 2011).

${ }^{26}$ Bertola and Ocampo, The Economic Development of Latin America since Independence, 51.
} 
government. For Italy, de Oliveira and Guerriero show that, after the unification in 1861, the southern territories were penalized by region-specific tax rates selected by the northern elite. ${ }^{27}$ Maranhão and Pernambuco were in a similar position, as Rio de Janeiro decided their fiscal policy and imposed an export tax on cotton only for northern provinces. These external costs, which decreased profits for cotton plantations, explain the existence of seemingly inefficient production arrangements in which the average planter did not improve productivity with clear incentives to do so, such as declining prices and - for Maranhão - no clear substitutes for production. ${ }^{28}$

The impact of fiscal policies on cotton trade also provides an opportunity to assess the impact of different policies between Brazil and other exporters such as the United States, which prohibited export taxes. ${ }^{29}$ Douglas Irwin argues that even with the United States' market power during the nineteenth century, a tax on cotton exports would have inflicted losses on domestic planters. ${ }^{30}$ Section 5.2, which presents estimates for the optimal rate of taxation in Brazil, shows that export taxes were especially detrimental to planters in Maranhão because they produced a staple that was a close substitute for upland cotton from the United States. Pernambuco, which exported a longer fiber, attended a market with less competition and higher profit rates.

With taxation higher than the optimal amount, the distribution of fiscal revenues (including those generated from trade) between the central government and the provinces remained a major problems during the whole nineteenth century. ${ }^{31}$ Much like other Latin American regions during the period, northeast Brazil faced the problem of taxation without representation. ${ }^{32}$ Therefore, another effect of fiscal centralization during the early nineteenth century refers to the provision of public goods, which is discussed in section 4.3. How political institutions affected the supply of local public goods is especially important because high inland transport costs are considered in the literature a key factor that limited the development of staple

\footnotetext{
${ }^{27}$ Guilherme de Oliverira and Carmine Guerriero, "Extractive States: The Case of the Italian Unification," Working Paper (Columbia Law School, February 10, 2017), 3.

${ }^{28}$ Stiglitz, "Rational Peasants, Efficient Institutions, and a Theory of Rural Organization: Methodological Remarks for Development Economics," 27.

${ }^{29}$ Richard Graham compared cotton production in the U.S with Brazilian coffee. Richard Graham, "Slavery and Economic Development: Brazil and the United States South in the Nineteenth Century," Comparative Studies in Society and History 23, no. 4 (October 1, 1981): 620-55.

${ }^{30}$ Irwin, "The Optimal Tax on Antebellum US Cotton Exports," 287.

${ }^{31}$ André Villela, "Distribuição Regional Das Receitas E Despesas Do Governo Central No II Reinado, 1844 1889," Estudos Econômicos (São Paulo) 37, no. 2 (June 2007): 250, doi:10.1590/S0101-41612007000200001; Aureliano Cândido Tavares Bastos, A provincia; estudo sobre a descentralisação no Brazil (Rio de Janeiro, B.L. Garnier, 1870).

32 Viveiros de Castro, "Historia Tributaria Do Brasil," 34; Alejandra Irigoin, "Representation without Taxation, Taxation without Consent: The Legacy of Spanish Colonialism in America," Revista de Historia Económica (New Series) 34, no. 02 (September 2016): 169-208, doi:10.1017/S0212610916000069.
} 
production in Brazil before the age of railroads. ${ }^{33}$ Fiscal data shows that the underinvestment in public goods, especially transport infrastructure, was not a result of insufficient resources, but of allocation. Indeed, as argued before, newspapers and other sources show that a multiplicity of taxes was repeatedly seen as one of the causes of misery among the provinces.

\subsection{The taxation of Brazilian cotton exports}

In July 1808, after his arrival in Brazil, the Prince Dom João enacted a chart that taxed all cotton exported from Pernambuco, Ceará, Pará, and Maranhão. Since these captaincies contained several territories that became separate provinces after 1821 , the chart indeed imposed a tariff on all northern territories. All revenues from the 600 réis on each arroba had - every semester - to be sent "imperatively" to the Royal Treasury, to maintain the "integrity and dignity of the crown." ${ }^{34}$ In addition to the new tariff, the government maintained previous taxes on cotton exports, such as the dízimo. ${ }^{35}$

The arrival of Dom João and his extensive royal court, estimated at 10,000 people, quickly created a demand for additional governmental revenues. ${ }^{36}$ The impact was so significant that legislative activity included a tax on ecclesiastic confession notes, to "assist the establishment" of the court. ${ }^{37}$ Brazil had one constitution between 1824 and 1889, but until the 1830 s the effective fiscal organization remained the same as in colonial times. The preservation of a "archaic" mode of colonial administration regarding fiscal policy became one of the first criticisms after the arrival of the royal family. ${ }^{38}$ During the colonial period, fiscal resources in Brazil were so poorly managed and organized that any additional government expense required a new contribution, which created over time a list of "special" revenues that made fiscal obligations more complex and burdensome.

Foreigners who visited cotton areas in the 1810s noticed the problem that the new export tax represented. In a comment on taxing cotton with the dízimo and the 600 réis, Henry Koster argued that "nothing can be more injudicious, than this double duty upon the chief article of exportation from that country to Europe." ${ }^{39}$ The French traveler Louis-François de Tollenare, on his visit to Pernambuco in 1816 , wrote that cumulative taxes weighted heavily on cotton

\footnotetext{
${ }^{33}$ Leff, "Economic Development and Regional Inequality."

${ }^{34}$ Collecção Das Leis Do Brazil de 1808, 91.

${ }^{35}$ Between 100 to 160 réis for each bag depending on the captaincy.

36 Wilcken, Império à deriva, 45.

${ }^{37}$ Viveiros de Castro, "Historia Tributaria Do Brasil," 27.

${ }^{38}$ Flory, Judge and Jury in Imperial Brazil, 1808-1871; "Brazil. Finanças," Correio Braziliense, 1810, 5 edition, sec. Miscellanea, 120-24.

${ }^{39}$ Koster, Travels in Brazil, 32.
} 
production. The dízimo, the 600 réis tax, and 100 réis for each bag, represented almost 20 percent of cotton's market price. He argued that such "unreasonable rate" was founded on the view by the Portuguese government that Europeans could not do without cotton from Pernambuco. Tollenare was outraged by the view of ministers in Rio de Janeiro who thought that the tax burden fell on Europeans, and not on Brazilian producers. ${ }^{40}$

But as prices declined after Tollenare's visit, it became clear that export taxes reduced profits and that only large and established planters, which owned the best parcels of land and often had political positions in the province - yielding for them a considerable complementary income - managed to continue production. ${ }^{41} \mathrm{~A}$ tax on exports discouraged planters to expand supply, but at the same time there was no incentive by the central government to reduce taxation because northern provinces contributed directly to Brazil's external debt in the $1820 \mathrm{~s} .{ }^{42} \mathrm{~A}$ large part of "additional revenues" in the empire annual budget used to pay for the foreign debt came from Bahia, Pernambuco, and Maranhão. ${ }^{43}$

As taxation increased in provinces that contributed more to the Brazilian foreign trade, cotton was among many other products taxed. With the Napoleonic wars, scarcity on a range of commodities in foreign markets prompted the government to increase taxation in almost all agricultural products. Among the new taxes, a royal chart from 1809 established new customs duties for all main export staples to finance the new Royal Board of Commerce. ${ }^{44}$ Table 5.1, which presents information from the British consul in Bahia of taxes on agriculture in 1818, shows the amount different products had to pay before the fiscal reforms in the 1830 s. The main difference that cotton had, therefore, was the level of taxes with fixed values (such as the 600 réis), which were independent of market prices. The reason for higher cotton taxation came from better international prices when the royal family arrived: cotton had an average of $11.7 \mathrm{~d}$. per arroba between 1808 and 1822, while coffee had average prices of 6.8d., and sugar 4.2d. per arroba. ${ }^{45}$ As argued before, an additional problem of the 600 réis tariff was that the money was not invested locally. The dizimo was the main source of provincial revenue, but 5 percent

\footnotetext{
${ }^{40}$ Tollenare, Notas dominicaes tomadas durante uma residencia em Portugal e no Brasil nos annos 1816, 1817 e $1818,123-25$.

${ }^{41}$ Mota, As Famílias Principais Redes de Poder No Maranhão Colonial, 50.

${ }^{42}$ See Chapter 3. On the increase in foreign loans during the 1820s, see Summerhill, Inglorious Revolution.

${ }^{43}$ Annaes Do Parlamento Brasileiro, 1826, sec. 27 de Julho de 1827, p.289. In the 1828 budget, the three provinces transferred 540 contos to the Rio de Janeiro Treasury.

${ }^{44}$ Viveiros de Castro, "Historia Tributaria Do Brasil," 33. It should be noted that these tax increases happened before the 1810 Commercial Treaty with Britain and, therefore, were not a decision based of external constraints that prohibited more revenues from imports.

${ }^{45}$ Cavalcanti, O Meio Circulante Nacional : Resenha E Compilação Chronologica de Legislação E de Factos, $1893,1: 315$.
} 
of cotton prices in Bahia at the time represented an average of 233 réis per arroba, one third the amount that was collected by the central government from the "subsidio" and the "novo imposto." Moreover, after cotton prices decreased in 1819, these taxes represented on average 19 percent of market prices, considerably higher than the 13 percent sugar planters had to pay. ${ }^{46}$ Table 5.1 - Taxes on agricultural products, 1809-1830

\begin{tabular}{lccc}
\hline & $\begin{array}{c}\text { "Subsidio paid by } \\
\text { the shipper" }\end{array}$ & $\begin{array}{c}\text { "Novo Imposto" } \\
\text { (July 1809) }\end{array}$ & $\begin{array}{c}\text { "duty falls on the } \\
\text { planter" (dízimo) }\end{array}$ \\
\hline Clayed Sugar & 60 réis per arroba & 160 réis per case & 10 percent \\
Brown Sugar & 30 réis per arroba & 80 réis per roll & 10 percent \\
Tobacco & 40 réis per arroba & 20 réis per hide & 5 percent \\
Cotton & 600 réis per arroba & 100 réis per bag & 5 percent \\
Hides & 20 réis per arroba & & \\
\hline
\end{tabular}

Source: BNA FO 63/215, folio 10.

In addition to taxation on exports, other taxes with lower marginal impact also increased trade and production costs. One important example was the "bank tax," enforced between 1812 and 1822 to complete the capital requirements for the 1808 statute of the first Bank of Brazil. ${ }^{47}$ Moreover, when cotton prices increased between 1815 and 1819, the central government began to "withdraw bills of large amounts" to finance other expenses of the court. ${ }^{48}$ Because of the destruction caused by the French invasion, Bahia, Pernambuco, and Maranhão had to make an annual payment to Portugal from its custom-house revenues for 40 years - a payment that was terminated after independence. ${ }^{49}$ Again, in 1824, the provincial treasuries (Juntas da Fazenda) of Bahia, Pernambuco, and Maranhão were tasked to help the central government's first loan with London after the independence. ${ }^{50}$ Much of the money from the loans, however, was spent with military operations such as the one organized to fight the 1824 northeast rebellions and, later, the war in the Cisplatine.

Fiscal information for Maranhão, presented in Table 5.2, shows that transfers to Rio de Janeiro amounted to 41 percent of all revenues during the cotton boom years. Trade represented on average 84 percent of revenues in Maranhão between 1816 and 1821, the years when detailed

\footnotetext{
46 "FO 63/215 - Consuls Alexander Cunningham, William Pennell, John Lempriere, Robert Hesketh, John Jeffery, John Crispin, William Harding Read, and Henry Veitch, Etc. (Portugal and Brazil)." 1818, fol. 10, The National Archives, Kew.

${ }^{47}$ Cavalcanti, O Meio Circulante Nacional : Resenha E Compilação Chronologica de Legislação E de Factos, 1893, 1:p.29.

${ }^{48}$ Viveiros, História do comércio do Maranhão, 1954, 1:138.

49 "Carta Régia," Gazeta Do Rio de Janeiro, January 15, 1812, 5 edition, 8, Memória Digital, Biblioteca Nacional. Bahia would have to make annual payments of 60,000 Cruzados, Pernambuco 40,000, and Maranhão 20,000 .

${ }^{50}$ Summerhill, Inglorious Revolution, 56.
} 
data are available. From almost thirty different fiscal sources, Maranhão government's revenues came mainly from three sources, two of them related to cotton. In Brazil, all domestic products had to pay a 10 percent tax (dízimo) when exported, with deductions for some products. In the case of cotton, the dízimo had a deduction of $1 \$ 280$ réis per arroba to abate the cost of ginning and transport after 1814. As the average price between 1816 and 1821 was $6 \$ 712$ for each arroba, the dízimo for cotton was in fact 8 percent (543 réis). The different impact between the dízimo and the 600 réis tariff - the one created in 1808 - appears more clearly in 1821, when local cotton prices plummeted. While revenues from the dizimo declined as expected, the new cotton tax transferred the burden of lower prices to planters.

Table 5.2 - Fiscal revenues and expenditures in Maranhão, 1816-1821 (mil-réis)

\begin{tabular}{ccccccc}
\hline Revenues & 1816 & 1817 & 1818 & 1819 & 1820 & 1821 \\
\hline Dízimo & 230,128 & 238,272 & 232,276 & 167,137 & 127,355 & 66,012 \\
$(\%)$ & $37 \%$ & $34 \%$ & $31 \%$ & $23 \%$ & $18 \%$ & $17 \%$ \\
600 réis tax & 215,295 & 243,725 & 230,275 & 225,272 & 211,031 & 153,319 \\
$(\%)$ & $34 \%$ & $35 \%$ & $31 \%$ & $.32 \%$ & $30 \%$ & $34 \%$ \\
Custom house & 110,636 & 147,891 & 221,367 & 229,353 & 175,470 & 122,355 \\
$(\%)$ & $18 \%$ & $21 \%$ & $29 \%$ & $32 \%$ & $25 \%$ & $27 \%$ \\
\hline Total Revenues & 626,762 & 697,896 & 751,221 & 714,872 & 709,295 & 451,879 \\
\hline Expenditures & & & & & & \\
Civil Salaries & 40,449 & 42,745 & 44,252 & 55,658 & 50,259 & 48,030 \\
$(\%)$ & $7 \%$ & $10 \%$ & $6 \%$ & $5 \%$ & $6 \%$ & $10 \%$ \\
Military Salaries & 53,225 & 48,280 & 52,400 & 50,448 & 50,448 & 104,039 \\
$(\%)$ & $9 \%$ & $11 \%$ & $6 \%$ & $5 \%$ & $6 \%$ & $24 \%$ \\
Remittances to RJ & 346,397 & 190,712 & 435,160 & 410,528 & 251,091 & 61,459 \\
$(\%)$ & $59 \%$ & $42 \%$ & $64 \%$ & $39 \%$ & $29 \%$ & $13 \%$ \\
\hline Total Expenditures & 581,801 & 450,048 & 835,877 & $1,061,699$ & 852,801 & 441,552 \\
\hline
\end{tabular}

Sources: Lago, Estatística histórico-geográfica.

The third important source of revenue in Table 4.2, labelled "custom house", refers to twelve other taxes, such as the dizimo for rice, the custom house's administrative fees and, the largest of them, stowage fees (51 contos). The revenue from the custom house after 1818 also included a $9 \$ 600$ tax for slaves arriving at the port, from which 600 réis went to Rio de Janeiro to cover local police costs. The remaining sum was divided half to the province and half to a fund that should be available to the Rio de Janeiro treasury for the new Bank of Brazil.

The large fiscal burden of taxes that were not converted in regional investments inevitably created a series of political tensions. As mentioned before, Maranhão did not initially 
recognized Brazil's independence because it wanted to reduce taxation from Rio de Janeiro. ${ }^{51}$ In 1829, with cotton prices reaching 5.75d in Liverpool, Maranhão's president declared that the economic condition demanded the reduction of the "disproportionate taxes" on cotton. The president argued that "with a $10 \$ 000$ or the [current] $2 \$ 300$ price," planters had to pay the same unfair rate. ${ }^{52}$ With shrinking fiscal revenues from northern provinces, the imperial government eventually acknowledged in 1830 that, with such low prices, the 600 réis tariff made the crop unprofitable, leading many planters to abandon cultivation. ${ }^{53}$ The following year the government abolished the tariff. Brazil's finance minister warned that the system of creating additional taxes to cover the costs of public administration had reached a limit: sugar and tobacco were taxed five times, and cotton three. ${ }^{54}$

With Brazil's finance minister denouncing the poor distribution of taxes, which penalized some products more than others, the necessity for a broad fiscal reform became clear across the nation in $1831 .{ }^{55}$ Changes began with the creation of the national treasury and the end of fiscal administrative houses in the provinces (Juntas da Fazenda) in 1832. Two years after, the government began a general reform in the provincial treasuries. ${ }^{56}$ The first major institutional change that separated public finances from colonial times in Maranhão were the reforms that followed the Additional Act in $1834 .{ }^{57}$ It was the first time that provinces had a legislation which specified resources to fund the local government. The Additional Act, however, still prohibited the provinces to tax imports, leaving exports as the only possible source of revenue from foreign trade. ${ }^{58}$ After the installation of a treasure house in 1835 , a bureaucratic structure to collect and supervise local revenues developed in Maranhão until the creation of the provincial treasury in $1838 .{ }^{59}$ In that year, the central government abolished the dízimo and replaced it with a new 5 percent tax on all provincial production, plus the imperial

\footnotetext{
${ }^{51}$ Vieira da Silva, História da independência da Província do Maranhão, 1822-1828.

52 “Discurso [...] Recitou Sr. Candido Joze de Araujo Vianna, Presidente D'esta Provincia," O Farol Maranhense, December 1, 1829, 146 edition, 621, Memória Digital, Biblioteca Nacional.

${ }^{53}$ Anais Do Senado Do Império Do Brasil. 1823-1888, bks. 1830, 3, p.586.

${ }^{54}$ Brasil. Ministério da Fazenda, "Ministro José Ignacio Borges. Relatório... Do Anno de 1830 Apresentado Na Sessão de 1831" (Rio de Janeiro, 1831), 13, Center for Research Libraries, Global Resources Network, http://brazil.crl.edu/bsd/bsd/u1510/000001.html.

${ }^{55}$ Ibid.

${ }^{56}$ Viveiros de Castro, "Historia Tributaria Do Brasil," 34.

${ }^{57}$ Oliveira, Systema financial do Brasil, 35.

${ }^{58}$ Marcelo de Paiva Abreu and Luiz A. Corrêa do Lago, "Property Rights and the Fiscal and Financial System in Brazil," in Transferring Wealth and Power from the Old to the New World: Monetary and Fiscal Institutions in the 17th Through the 19th Centuries, ed. Michael D. Bordo and Roberto Cortés-Conde (Cambridge University Press, 2006), 345.

${ }^{59}$ Jerônimo de Viveiros, História do comércio do Maranhão, vol. 2 (São Luís: Associação Comercial Maranhão, 1954), 320.
} 
export tax of 7 percent. In 1843, the provincial government reduced its cotton export tax to 3 percent but had to increase it again in 1847 due to financial difficulties. ${ }^{60}$ Public works like the cleaning of rivers to ease navigation had to be interrupted and the government eventually increased the tax back to 5 percent. ${ }^{61}$ The fiscal organization after 1848 continued without significant changes throughout the monarchic period and, with no revenues from import tariffs and having only part of revenues from exports, provinces remained budget constrained.

When it was in effect, between 1809 and 1830, the 600 réis tariff represented on average 14 percent of cotton prices. Adding the other taxes, the average export tax rate between 1809 and 1830 was 22 percent. Export taxes represented a much higher cost than transportation from plantations to Brazilian ports. The cost to transport cotton in mules from the hinterlands in Pernambuco to the port in 1817 was between 200 to 300 réis per arroba, when the price of cotton was $6 \$ 500 .^{62}$ In Maranhão transportation by boat to São Luís represented only 1.3 percent of production costs in $1813 . .^{63}$ Several decades later, in 1854, when agricultural production had already expanded far inland, it was reported that transportation costs of various products to São Luís ranged between 10 and 30 percent. ${ }^{64}$ Other sources, however, show that transportation costs for cotton represented between 2.8 and 5.5 percent of market prices during the $1850 \mathrm{~s} .{ }^{65}$ As cotton expanded to the interior, transport costs increased also because of the intermediation of numerous brokers (despachantes), inspectors, and middlemen. ${ }^{66}$ Including all these costs, the transport of cotton bags to the port probably did not surpass 10 percent of market prices. The burden of the export tariffs on producers, therefore, was much higher than internal transport costs.

Figure 5.1 presents the share of taxes on cotton prices in Maranhão between 1809 and 1850. The most significant change occurred in 1830, when the central government abolished the 600 réis tariff. To counterbalance the reduction in revenues, the central government ended the dízimo deductions and continued to charge 100 réis on each cotton bag until 1833 . These

\footnotetext{
60 “Ainda a Lei Do Orçamento Deste Anno," O Observador, October 6, 1847, 11-12 edition, 4, Memória Digital, Biblioteca Nacional.

${ }^{61}$ Lei n.150-A, 13 julho, p.323, relatório Alexandre Teófilo 1850.

62 Tollenare, Notas dominicaes tomadas durante uma residencia em Portugal e no Brasil nos annos 1816, 1817 e 1818, 116.

${ }^{63}$ Gayoso, Compendio Historico-Politico Dos Principios Da Lavoura Do Maranhão, 264.

64 “Relatorio Do Presidente Da Provincia Do Maranhão, O Doutor Eduardo Olimpio Machado, Na Abertura Da Assembléa Legislativa Provincial No Dia 3 de Maio de 1854, Acompanhado Do Orçamento Da Receita E Despeza Para O Anno de 1855."

${ }^{65}$ Mesquita, Vida e morte da economia algodoeira do Maranhão, 204.

${ }^{66}$ Ibid., 229.
} 
changes left provincial export duties like those applied to Rio de Janeiro, which amounted to 12 percent (dízimo plus 2 percent provincial export tax).

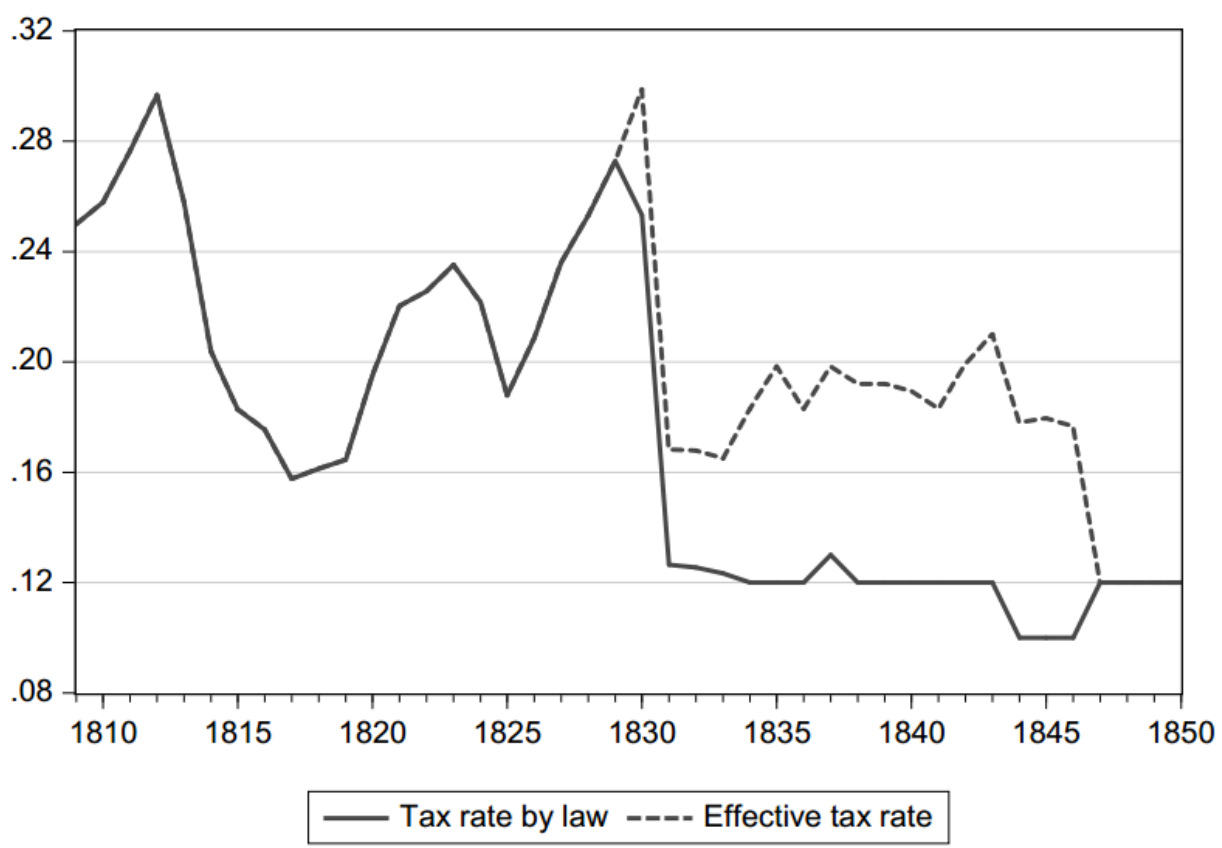

Figure 5.1 - Cotton Export Tax in Maranhão, 1809-1850

Source: Coleção de Leis do Império Brasil (1808-1889). See Table A6 in the appendix.

However, as Figure 5.1 shows, planters kept paying higher taxes after 1830 despite the cut in nominal taxes. The reason was related to policies during the 1830s that required taxes to be paid in hard currency while it allowed the payment of export goods in undervalued currency. Multiple currencies reduced the profits of cotton planters and, in 1833, a representation by British merchants to the Brazilian government explained the costs of local fiscal policy to trade:

$[\ldots]$ that for some years the government of this province has enacted three fourths of all duties, on imports and exports, in silver, which while the premium continued moderate was not felt, and could not be considered any grievance. That lately the premium on silver has attained such a high rate (and even with difficulty to be got) that all commercial transactions are nearly suspended, upwards of a hundred per cent has been paid, and even more has been asked. ${ }^{67}$

The trade paralysis from the scarcity of silver coins in the early 1830s generated an economic crisis that had been building up since the previous decade. During the 1820s, foreign loans and the Cisplatine War (1825-28) led to an increase in emissions of paper money and coinage of copper, devaluating the exchange rate in Rio de Janeiro. ${ }^{68}$ Between 1827 and 1831 ,

67 “Consuls Wilson, John Moon, James F. Tauton, Henry Cowper. FO 13/104” 1833, 72-73, The National Archives, Kew.

${ }^{68}$ Peláez and Suzigan, História monetária do Brasil, 46. 
the exchange rate in Rio de Janeiro was on average $28.3 \mathrm{~d}$ (per $1 \$ 000$ ), while it reached $46 \mathrm{~d}$ in Maranhão, and 50.5d in Pernambuco. Pernambuco and Maranhão initially were not affected by Rio de Janeiro's monetary crisis because paper money did not circulate in northern provinces before 1830, and the central government prohibited copper coin exports from Rio de Janeiro and Bahia to other provinces between 1827 and $1830{ }^{69}$

At the height of the crisis, in January 1830 the premium for silver reached 98 percent in Rio de Janeiro, while in Pernambuco it was still between 10 and 24 percent. ${ }^{70}$ But even before undervalued money started to flow to the northeast - and arbitrage opportunities between difference provinces began to reduce - a group of more than thirty cotton and sugar planters from Pernambuco signed in 1830 the first of a series of petitions to the central government demanding reforms in the method of tax collection. Cotton taxes (dízimo and subsídio) paid in silver coins accounted for 840 réis per arroba, but with the undervalued copper coins the cost increased at least 20 percent, reaching $1 \$ 008$ in a moment when cotton prices were on average $3 \$ 200$. Many merchants were also buying less cotton and sugar because of the obligation to pay taxes with silver coins, which were becoming scarce over time. The petitioners argued that their products had to compete in the European market with suppliers that did not suffer these “indignities" nor had to pay export taxes, using the United States as an example. ${ }^{71}$

With the end of copper exports restriction from Rio de Janeiro and Bahia in 1831, the silver premium in Pernambuco and Maranhão rapidly increased, worsening the tax collection problem. As differences between the face value of copper coins and their metal content widened, factories to counterfeit copper coins appeared in Pernambuco and Maranhão. ${ }^{72}$ The situation led the government to announce in 1833 a nationwide monetary reform, which would substitute the copper coins and the undervalued paper money from the old Bank of Brazil with a new standard. With the new monetary standard, planters hoped they would finally be able to receive the payment for their produce in the same currency as they had to pay taxes. But that hope did not last. In 1834 the government of Maranhão announced that obligations to the

\footnotetext{
${ }^{69}$ Collecção Das Leis Do Imperio Do Brazil, bk. 1831 V.2 p.13; Oliveira, Systema financial do Brasil, 56-59.

70 “Carta Ao Editor," Diario de Pernambuco, January 25, 1830, 298 edition, 1198, Memória Digital, Biblioteca Nacional.

71 "Requerimento a Que Se Referem Reflexões Do Nosso Correspondente," O Constitucional. Jornal Politico E Literário, April 15, 1830, 83 edition, 2-4.

72 Viveiros, História do comércio do Maranhão, 1954, 1:178; “Artigo D’officio,” Diario de Pernambuco, May 27, 1831, 112 edition, Memória Digital, Biblioteca Nacional; "Artigo d'Officios," O Publicador Official, September 28, 1833, 196 edition, Memória Digital, Biblioteca Nacional.
} 
custom-house had to keep been paid $3 / 4$ in silver and $1 / 4$ in paper money. Newspapers reported that the measure caused a "general outcry" from all those that held paper money. ${ }^{73}$

The measure shook the confidence in the new currency, and there were doubts if the new bills issued by the Bank of Brazil were equivalent to gold and silver coins. Public statements asked why merchants (negociantes em grosso) - who had the largest obligations with the public treasury - should accept a currency that could not serve to make all payments and transactions at Brazilian ports. The result was that merchants began to accept paper money from their debtors only in exchange for a large premium. ${ }^{74}$ A petition by British merchants in 1834 claimed that the substitution of copper coins for paper notes in the previous year caused a loss of 10 percent in their income, although merchants consented to the measure in the hope of paying taxes using the new paper bills. ${ }^{75}$ In any case, the change in rules seemed arbitrary because a law from October, 1833 (which set the new standard) made explicit that the substitution of copper coins for paper notes would make the latter a fiduciary standard to pay taxes.

Maranhão's newspapers began to report cotton prices in silver and paper money. After copper coins began to be removed from circulation in 1835, silver coins kept a premium between 70 and 90 percent of paper bills' value, maintaining the problem with tax payments. A petition signed by 56 merchants and businessmen asked the government of Maranhão to revoke the provincial law of 1834 that required 3/4 of taxes to be paid in silver coins. As Pernambuco's planters had also argued, the Imperial law of October $3^{\text {rd }}, 1833$, allowed public partitions to accept paper notes. ${ }^{76}$ With no changes in sight, Maranhão's treasury inspector declared in 1837 that many cotton planters near Piauí transported their produce across the border to avoid higher taxation. ${ }^{77}$ By contrast to the main city ports in Brazil, smaller provinces such as Piauí, Ceará, and Pará accepted copper coins as tax payments. ${ }^{78}$ The situation lingered without solution, and

\footnotetext{
73 “Maranhão," Echo Do Norte, October 14, 1834, 29 edition, Memória Digital, Biblioteca Nacional.

74 “Sobre a Lei Monetaria de 3 de Outubro Proximo Passado," Echo Do Norte, July 14, 1834, 4 edition, sec. Maranhão, 2, Memória Digital, Biblioteca Nacional.

75 “Consulado Britanico, Representação,” O Publicador Official, October 22, 1834, 307 edition, Memória Digital, Biblioteca Nacional.

76 "Representação; Os Abaixo Assignados Negociantes, E Proprietarios Desta Cidade," O Publicador Official, March 25, 1835, 351 edition, 1438, Memória Digital, Biblioteca Nacional.

77 “Maranhão: Artigos D’Officio,” O Publicador Official, May 24, 1837, 553 edition, 4555, Memória Digital, Biblioteca Nacional.

78 “Consuls Wilson, John Moon, James F. Tauton, Henry Cowper. FO 13/104,” 72-73.
} 
a congressman from Pernambuco stated in 1840 that in his province provincial taxes were still collected in silver. ${ }^{79}$

The problem with the scarcity of hard currency and the payment of custom duties persisted until the monetary reform of 1846 . With the reform, the government finally accepted that the exchange rate set in 1833 was too high and lowered the par value of the mil-réis. ${ }^{80}$ The government expanded the supply of metal coins, and foreign silver coins began to be accepted at custom-houses in $1847 .{ }^{81}$ These measures reduced the silver premium and attenuated the distortions in the export tax. After four decades, cotton exports taxes finally reduced in northern provinces, but the impact of Rio de Janeiro's fiscal policies had taken its toll.

\subsection{The optimal export tax for Brazilian cotton}

As the previous section showed, export taxes reduced profits for cotton planters in the northeast and created disincentives to expand production. But what was the optimal export tax for cotton? If the export tax imposed by the central government was lower than the optimal level, exporters would still have incentives to continue producing cotton, even with low international prices. Following Douglas Irwin's analysis for the optimal tax in the United States, first is necessary to calculate the elasticity of export demand for Brazilian cotton $\left(\eta_{B R}\right)$, where $\varepsilon$ is the elasticity of export supply from other cotton producers, $S$ is the Brazilian share of the British market, $\sigma$ is the elasticity of substitution between Brazilian and foreign varieties of cotton, and $\eta$ is the price elasticity of British demand for Brazilian cotton. ${ }^{82}$ When products are homogenous, i.e., the Brazilian and the U.S. varieties are perfect substitutes, the elasticity of substitution approaches infinity and the equation simplifies:

$$
\begin{aligned}
& \eta_{B R}=\frac{\varepsilon[(1-s) \sigma+s \eta]+\sigma \eta}{s(\sigma-\eta)+\eta+\varepsilon} \\
& \text { when } \sigma \rightarrow \infty, \eta_{B R}=\frac{\eta}{s}+\frac{(1-s)}{s} \varepsilon
\end{aligned}
$$

\footnotetext{
${ }^{79}$ Antonio Henoch dos Reis, Camara Dos Srs. Deputados. Terceiro Anno Da Quarta Legislatura. Sessão de 1840 (Rio de Janeiro: Typographia da Viuva Pinto \& Filho, 1884), 618.

${ }^{80}$ Peláez and Suzigan, História monetária do Brasil, 67.

${ }^{81}$ Amaro Cavalcanti, O Meio Circulante Nacional : Resenha E Compilação Chronologica de Legislação E de Factos, vol. 2 (Rio de Janeiro: Imprensa Nacional, 1893), 188.

82 Irwin, "The Optimal Tax on Antebellum US Cotton Exports."
} 
With the price elasticity of export demand for Brazilian cotton, the optimal export tax $\tau$ $=1 / \eta_{B R}$ is the equilibrium between the marginal revenue for cotton exports $P^{U K}=(1-$ $\left.1 / \eta_{B R}\right)$ and the domestic price of cotton $P=P^{U K}(1-\tau)$, with world cotton prices equivalent to prices in the United Kingdom. The elasticity of export demand for Brazilian cotton, therefore, depends on the elasticity of substitution with cotton from the United States, given by the following equation:

$$
\sigma_{i j}=1+\gamma_{i j} / w_{i} w_{j}
$$

The Hicksian elasticity of demand for the $i$ th good with respect to the price $j$ th is:

$$
\eta_{i j}=\frac{\gamma_{i j}}{w_{i}}-\frac{\beta_{i}}{w_{i}} w_{j}-\delta_{i j}
$$

where $\delta_{i j}$ is the Kronecker delta, with $\delta_{i j}=1$ for $i=j$ and $\delta_{i j}=0$ for $i \neq j$.

Both equations depend on parameters that are estimated with an Almost Ideal Demand System, developed by Deaton and Muellbauer. ${ }^{83}$

$$
w_{i t}=\alpha_{i}+\sum_{j=1}^{n} \gamma_{i j} \ln p_{j t}+\beta_{i} \ln \left(\frac{x_{t}}{P_{t}}\right)+u_{t}
$$

Where $t$ is the index of time, $w_{i t}$ is the British expenditure share of cotton from country $i, p_{j t}$ is the price of cotton from different countries (index by $j$ ), $x_{t}$ is total expenditures on cotton by Britain, $u_{i t}$ is a random disturbance, and $P$ is a price index defined by the following linear approximation:

$$
\ln P_{t}=\sum_{k=1}^{n} w_{k t} \ln \left(p_{k t}\right)
$$

One known problem with the parameters in this model is that the elasticity estimates have a downward bias. ${ }^{84}$ Irwin explains that the bias results from the assumption that export supply from different countries are perfectly elastic when in fact they are upward sloping. ${ }^{85}$ One

\footnotetext{
${ }^{83}$ Angus Deaton and John Muellbauer, “An Almost Ideal Demand System,” The American Economic Review 70, no. 3 (1980): 312-26.

${ }^{84}$ Shida Rastegari Henneberry and Seong-huyk Hwang, "Meat Demand in South Korea: An Application of the Restricted Source-Differentiated Almost Ideal Demand System Model," Journal of Agricultural and Applied Economics 39, no. 1 (April 2007): 47-60, doi:10.1017/S1074070800022744.

${ }^{85}$ Irwin, "The Optimal Tax on Antebellum US Cotton Exports," 283.
} 
way to solve the parameters' bias is to apply instrumental variables that are related to supply conditions for the exporting countries. For example, Wahl and Hayes, correcting for endogeneity in prices in an Almost Ideal Demand System, find that the calculated elasticities are twice as large. ${ }^{86}$

Given the endogeneity problem, I use the calculated cost for cotton production in Maranhão presented in Chapter 4 as an instrumental variable to correct the estimates for Brazilian elasticities. To check if the results are consistent, I estimate Irwin's iterative seemingly unrelated regressions (SUR) using the same data: quantities and prices for cotton from the United States, Brazil, East Indies, and Egypt between 1820 and 1859. ${ }^{87}$ Since only information on Brazilian production costs is available, the estimation with instrumental variables (IV) does not consider the entire system. However, the OLS estimation for the demand equation of Brazilian cotton does not show any significant changes in the parameters from the SUR estimation. One important fact for the estimation of the optimal tax is that Brazil, differently from the United States, had an export tax in place between 1820 and 1860. As the domestic price is the international price (ignoring transport costs) minus the tariff, not considering the presence of the Brazilian export tax will overstate the domestic cotton price planters received by their product. With higher domestic prices, higher taxes would have been bearable to planters. To consider this difference I add the variable Tax to the IV regression as a control, which is the average amount that cotton exporters in Maranhão paid each year in taxes. Table 5.3 presents these results and shows that - consistent with other studies - controlling for endogeneity doubles the estimates of $\gamma$ for Brazil, while also increasing the parameter for the United States.

Table 5.3: Estimation of demand for Brazilian cotton in UK, 1820-1859

\footnotetext{
${ }^{86}$ Thomas I. Wahl and Dermot J. Hayes, "Demand System Estimation with Upward-Sloping Supply," Canadian Journal of Agricultural Economics/Revue Canadienne D'agroeconomie 38, no. 1 (March 1, 1990): 107-22, doi:10.1111/j.1744-7976.1990.tb03451.x.

${ }^{87}$ Mann, The Cotton Trade of Great Britain.
} 


\begin{tabular}{|c|c|c|c|}
\hline & SUR & OLS & IV \\
\hline \multirow[t]{2}{*}{$\boldsymbol{\alpha}$} & $2.19 *$ & $2.10 *$ & $2.10 *$ \\
\hline & $(0.22)$ & $(0.24)$ & $(0.26)$ \\
\hline \multirow[t]{2}{*}{$\boldsymbol{\beta}$} & $-0.10 *$ & $-0.10 *$ & $-0.09 *$ \\
\hline & $(0.01)$ & $(0.01)$ & $(0.01)$ \\
\hline \multirow{2}{*}{$\gamma_{B R-B R}$} & $-0.13 *$ & $-0.13 *$ & $-0.28 *$ \\
\hline & $(0.06)$ & $(0.06)$ & $(0.10)$ \\
\hline \multirow{2}{*}{$\gamma_{B R-U S}$} & $0.23 *$ & $0.24 *$ & $0.33^{*}$ \\
\hline & $(0.06)$ & $(0.08)$ & $(0.10)$ \\
\hline \multirow{2}{*}{$\gamma_{B R-E I}$} & -0.03 & -0.03 & -0.04 \\
\hline & $(0.04)$ & $(0.05)$ & $(0.05)$ \\
\hline \multirow[t]{2}{*}{$\operatorname{Tax}$} & & & $0.06^{*}$ \\
\hline & & & $(0.02)$ \\
\hline$R^{2}$ & 0.85 & 0.85 & 0.86 \\
\hline
\end{tabular}

Note: Standard errors in parenthesis. *Significance at the $5 \%$ level. See appendix X for full regression.

With the estimated parameters, Table 5.4 show price elasticities for Brazil and the United States, along with the calculated optimal tax for Brazilian cotton. I assume the elasticity of export supply from the United States $(\varepsilon)$ equal to 1 . Despite being probably higher, changing the elasticity magnitude does not alter the results significantly. ${ }^{88}$ Positive price elasticities for the United States confirm what British market reports at the time described: short staple cotton from the U.S. was a substitute for Brazilian cotton. The calculation for the optimal tax uses two different values for the Brazilian share in the British market $(s)$ : 11 percent, which is the average market share between 1820 and 1859, and 5 percent, which is the average share after 1840 . The last parameter, the elasticity of substitution between Brazilian and other varieties of cotton $(\sigma)$, deserves some clarification since the cotton market structure in Brazil had some differences compared to other countries. The data used to estimate the elasticities, from James Mann (1860), does not separate prices and quantitates of different staples exported by the same country. This does not represent an issue for the East Indies and Egypt, which exported mainly one kind of cotton. For the United States, exports of Sea Island represented a small share of total exports and, therefore, did not affect average prices. For Brazil, however, while Pernambuco and Maranhão had equivalent market shares, they exported different types of cotton for separate segments of the British textile sector. Pernambuco mostly exported longstaple cotton while Maranhão exported short-staple, which competed with the high productivity

\footnotetext{
${ }^{88}$ Gavin Wright, “An Econometric Study of Cotton Production and Trade, 1830-1860," The Review of Economics and Statistics 53, no. 2 (1971): 111-20, doi:10.2307/1925706.
} 
regions of the United States. The elasticity of substitution $\sigma$ for Maranhão, therefore, was considerably higher than for Pernambuco.

Table 5.4: Implied price elasticities of UK demand for Brazilian cotton

\begin{tabular}{cccc}
\hline & SUR & OLS & IV \\
\hline Price elasticities BR & -2.08 & -1.99 & -3.46 \\
Price elasticities US & 2.80 & 2.89 & 3.61 \\
$\sigma$ & 3.68 & 3.80 & 4.82 \\
$\eta_{B R}$ & 3.42 & 3.49 & 4.63 \\
Tariff $(\tau), s=0.11$ & $29 \%$ & $29 \%$ & $22 \%$ \\
$\tau$, with $\sigma=\infty$ & $4 \%$ & $4 \%$ & $2 \%$ \\
Tariff $(\tau), s=0.05$ & & & $11 \%$ \\
$\tau$, with $\sigma=\infty$ & & & $1.5 \%$ \\
$\varepsilon$ & 1 & 1 & 1 \\
\hline
\end{tabular}

Moreover, Mann's book describes Brazilian cotton prices as "Brazil \& Pernambuco," but comparing his information with prices from newspapers in Liverpool shows that prices are only for Pernambuco. ${ }^{89}$ Therefore, the optimal export tariff of 22 percent - with the estimated $\sigma$ of 4.82 - is under the assumption that the entire market share of Brazil was from Pernambuco's long-staple cotton. Under this assumption, the optimal tax for Pernambuco exports was the same as the average rate for the period. Nonetheless, the market for long-staple cotton had less competitors and was much smaller than for shorter varieties. Cotton from Maranhão, however, faced a different market, especially after the 1830s when Maranhão also exported saw-ginned cotton. Saw-ginned cotton from Maranhão competed with the new cotton regions of the United States and, therefore, its elasticity is closer to the assumption when products are homogenous $(\sigma=\infty)$. With homogeneity, the optimal export tariff was ten times lower than the actual tariff planters had to pay to the central government between 1820 and 1860 .

\subsection{Conclusions}

The evidence presented in this chapter reinforces the argument that slow productivity growth in the northeast was a result of the low profitability of short-staple cotton crops. Exports taxes on cotton, established to sustain the new government in Rio de Janeiro, represented the largest production cost between 1808 and 1850 and captured a significant part of the gains from long-distance trade that would allow local expansion of cotton plantations in the northeast. With

${ }^{89}$ Mann, The Cotton Trade of Great Britain. 
fiscal transfers to Rio de Janeiro, the provinces did not have the resources to invest in public goods such as improved roads and waterways, which would lower production costs. The depression in the cotton sector, therefore, was not caused by international markets because Liverpool prices remained well above production costs in Brazil for almost all the period. The usual culprits of cotton stagnation in Brazil, such as inefficient use of land by farmers, and a lack of capital for investment, also don't consider the impact of high export taxes for investment decisions.

The impact of political centralization, however, was larger than the imposition of multiple export taxes. After the end of the 1808 tariff, the scarcity of silver coins in the 1830 s perpetuated high production costs since all foreign trade taxation involved hard currency. Changes came only in the 1847, with a national monetary reform and when cotton prices achieved their lowest point in the first half of the nineteenth century. By then, cotton planters in Maranhão and Pernambuco had been bearing high production costs for almost four decades, and now faced new international competition from the East Indies and Egypt.

With information on international and domestic prices, production costs, and foreign demand shocks, there is still one hypothesis for the stagnation of cotton exports in Brazil that need to be discussed: the shortage of slave labor. The next chapter therefore, presents population information to analyze the argument that the growth in the coffee economy provoked a shortage of slave labor - through migration to southern regions - in cotton areas. Contrary of what is commonly assumed, census and inventory data show that Maranhão did not have a decline in the slave population until 1840s, long after the exports stagnation had begun. Maranhão also had one of the highest shares of slaves among the Brazilian provinces. 


\section{Slavery on cotton plantations}

In 1863, a New York Times correspondent in Pernambuco reported that, in "the center of the cotton trade" in Brazil, cotton cultivation was "carried on by white men and free halfbreeds." Competition from areas growing sugar and coffee - which after 1850 made slave labor more profitable - led authors such as Stanley Stein and Alice Canabrava to argue that cotton was a "poor man's crop."2 Luiz Barbosa extended this idea back to the early nineteenth century and argued that cotton was mostly associated with poor farmers who did not employ a large slave labor force. ${ }^{3}$ However, there is evidence that until 1820, slaves, not poor free farmers, cultivated the cotton exported from Brazil to Britain and other countries in Europe. ${ }^{4}$ And far from being a "poor man's crop", during the first quarter of the nineteenth century, large estates controlled cotton production in Maranhão. ${ }^{5}$ Several large planters not only held important political positions, but also were involved in the slave trade.

This chapter shows that slavery on cotton plantations began to decline only in the 1840 s, more than two decades after cotton exports stopped growing. Therefore, the reduction in Maranhão's slave population was a result, not a cause, of the stagnation in cotton exports. To address the importance of slave labor for cotton production during the first half of the nineteenth century, sections 6.1 and 6.2 present population statistics for cotton regions, using the first national census of 1872 as a benchmark to correct for possible biases. Information from population maps shows that up until 1840, slaves accounted for half the population in Maranhão, a higher share than other northeastern regions of Brazil and comparable to cotton regions in the United States. Sections 6.3 and 6.4 discuss two potential sources of slave labor for cotton plantations: population growth and the transatlantic slave trade. Consistent with previous findings, gender ratio imbalance and high mortality rates caused a negative rate of natural growth in the slave population, making planters dependent on the slave trade. ${ }^{6}$ This was an important demographic difference in comparison with the United States, where a positive

\footnotetext{
1 "FROM BRAZIL.; The Times in Brazil--The Activity of Pernambuco," The New York Times, December 19, 1863.

${ }^{2}$ Stein, Origens e evolução da indústria têxtil no Brasil, 60; Canabrava, O Desenvolvimento Da Cultura Do Algodão Na Província de São Paulo, 1861-1875, 159.

${ }^{3}$ Barbosa, "Cotton in 19th Century Brazil: Dependency and Development," 31.

${ }^{4}$ Prado Jr, Formação do Brasil contemporâneo, 152.

${ }^{5}$ Antonia da Silva Mota and Daniel Souza Barroso, "Economia e demografia da escravidão no Maranhão e no Grão-Pará: uma análise comparativa da estrutura da posse de cativos (1785-1850)," Revista de História, no. 176 (January 27, 2017): 01-41, doi:10.11606/issn.2316-9141.rh.2017.121833.

${ }^{6}$ Francisco Vidal Luna and Herbert S. Klein, "Slave Economy and Society in Minas Gerais and São Paulo, Brazil in 1830," Journal of Latin American Studies 36, no. 01 (February 2004): 7, doi:10.1017/S0022216X03007053; Mesquita, Vida e morte da economia algodoeira do Maranhão, 136.
} 
rate of natural growth was the norm. ${ }^{7}$ Section 6.5 looks at slave prices and finds an unexpected result: while slave prices were similar throughout Brazil during the first half of the nineteenth century, they were higher in Maranhão during the cotton boom period. Overall, these results show that cotton production in Maranhão mobilized a great deal of resources until the 1840s, and that exports were far from being a small-scale economic activity.

\subsection{Population statistics}

How do the slave populations in Maranhão and Pernambuco compare to those from other regions in Brazil and the cotton-producing areas of the United States? As the first Brazilian census was compiled only in 1872 , data for the provincial population for the first half of the nineteenth century are sparse. ${ }^{8}$ The local town censuses (listas nominativas) provide detailed information on population for some Brazilian regions, but they are not available, to my knowledge, for the cotton growing regions of Maranhão and Pernambuco.

The most widely used source for provincial populations for the early nineteenth century is a census from 1819 by A. R. Veloso de Oliveira. ${ }^{9}$ In his study, Oliveira criticizes a previous attempt to estimate the Brazilian population made by Henry Hill, the United States consul in Bahia in 1817, who estimated a population of 3 million for 1815. Since Hill did not have access to a census conducted between 1797 and 1798, which already listed a population of 3 million, Oliveira stated that the consul's estimates were mere speculations. ${ }^{10}$ In addition, a previous calculation made by the Abbot Corrêa da Serra already established that the Brazilian population in 1810 was already around 4 million inhabitants. ${ }^{11}$

The data provided by Oliveira have been used in important studies on the Brazilian population, such as those by Roberto Simonsen and, more recently, Angus Maddison. ${ }^{12}$

\footnotetext{
${ }^{7}$ Richard H. Steckel, The Economics of U.S. Slave and Southern White Fertility (New York: Garland, 1985); Richard S. Dunn, A Tale of Two Plantations: Slave Life and Labor in Jamaica and Virginia (Harvard University Press, 2014), 3.

${ }^{8}$ For a description of problems with censuses, see Dauril Alden, "The Population of Brazil in the Late Eighteenth Century: A Preliminary Study," The Hispanic American Historical Review 43, no. 2 (1963): 173-205, doi: $10.2307 / 2510491$.

${ }^{9}$ Antonio Rodrigues Velloso de Oliveira, “A Igreja Do Brasil,” Revista Do IHGB XXIX, no. Parte Primeira (1866): 159-200.

${ }^{10}$ Ibid., 177.

${ }^{11}$ Joaquim Norberto de Souza e Silva, Investigações Sobre Os Recenseamentos Da População Geral Do Império E de Cada Província de per Si Tentados Desde Os Tempos Coloniais Até Hoje, Ed. fac-similada (São Paulo: Instituto de Pesquisas Econômicas, 1986). For a full list of the total population estimates see http://memoria.ibge.gov.br/sinteses-historicas/historicos-dos-censos/censos-demograficos.html

12 According to Maddison, the population in Brazil in 1820 was 4.5 million. Simonsen, História Econômica Do Brasil (1500/1820), 271; 450. The difference is that Simonsen adds Mato Grosso and Goiás, raising Brazil's population to 4.480 .468 .
} 
Oliveira's estimates relied on information provided by local parishes from different captaincies during the period from 1808 to $1820 .{ }^{13}$ For example, the region of Ceará-Grande, which belonged to the Archbishopric of Maranhão, collected data for 1808, while a large part of the information for Pernambuco was for 1820. Nonetheless, most records dated from between 1814 and 1817. Putting together these maps, the Brazilian population in 1819 was 2,697,099 without counting the indigenous population, an estimated 800,000 people. Oliveira draws attention to the notorious inaccuracy of the maps, notably the fact that children under seven years of age were not listed, as well as other "known" absences. ${ }^{14}$ Given these limitations, Oliveira added another quarter to the previously estimated population, and a third for two regions (Ceará and Coritiba) that had older population maps. With these adjustments, the population increases to 3,596,132, and with the addition of 800,000 Indians, the total estimated population in 1819 is $4,396,132$.

Oliveira's survey was also considered the main source of population statistics in Brazil at the time. Henry Chamberlain, British Consul General in Rio de Janeiro, sent Oliveira's figures to the British Foreign Office in September 1822, in a letter containing information on the "supposed population of Brazil.." ${ }^{15}$ However, it is worth noting that the numbers provided by Chamberlain, later duplicated by Roberto Simonsen, are for archbishoprics, not captaincies. Since archbishoprics represented a larger geographical division than captaincies, their population figures can be misleading. As an illustration, the southern - and distant - bishoprics of Porto Alegre and Santa Catarina were part of Rio de Janeiro's archbishopric. The archbishopric of Maranhão contained the regions of Piauí, Ceará-Grande, and the village of Crato, all of which were not part of the captaincy. Table 6.1 shows Oliveira's estimates for archbishoprics and for captaincies. The numbers for the captaincies are considered the standard population for Brazil in 1819, adopted by many recent studies. ${ }^{16}$

\footnotetext{
${ }^{13}$ They were collected by the "ouvidor ao desembargo do paço." Because the main document is dated June 28th, 1819 , it seems that the maps were added after and the final document published on a later date.

${ }^{14} \mathrm{He}$ doesn't provide details about these absences: "e das pessoas, que deviam andar demais alistadas, sem discutir as causas, que por mui notorias não é preciso referir." Velloso de Oliveira, "A Igreja Do Brasil,” 178.

${ }^{15}$ From H Chamberlain 1822 Jan-Sept BNA FO 63/246, p.285

${ }^{16}$ Laird Bergad, The Comparative Histories of Slavery in Brazil, Cuba, and the United States (Cambridge University Press, 2007), 9; João Luís Ribeiro Fragoso and Manolo Florentino, O arcaísmo como projeto: mercado atlântico, sociedade agrária e elite mercantil em uma economia colonial tardia : Rio de Janeiro, c.1790-c.1840 (Rio de Janeiro: Civilização Brasileira, 2001), 112; Herbert S. Klein and Francisco Vidal Luna, Slavery in Brazil (Cambridge University Press, 2010), 76.
} 
Table 6.1 - Population of the seven bishoprics in Brazil c.1819

\begin{tabular}{lcccc}
\hline & \multicolumn{2}{c}{ Archbishoprics } & \multicolumn{2}{c}{ Provinces } \\
& Free Population & Slaves & Free Population & Slaves \\
\hline Bahia & 419,432 & 173,476 & 330,649 & 147,263 \\
Rio de Janeiro & 505,543 & 200,506 & 363,940 & 146,060 \\
São Paulo & 269,379 & 122,622 & 167,323 & 81,000 \\
Minas Gerais & 456,675 & 165,210 & 456,675 & 165,210 \\
Pernambuco & 455,248 & 192,559 & 273,832 & 97,633 \\
Maranhão & 261,220 & 201,176 & 66,668 & 133,332 \\
Pará & 121,246 & 51,840 & 92,901 & 33,000 \\
\hline Total & $2,488,743$ & $1,107,389$ & $1,751,988$ & 803,498 \\
\hline
\end{tabular}

Source: See text

The main northeast regions, comprising Bahia, Pernambuco, and Maranhão, totaled 30 percent of the Brazilian population and 34 percent of slaves. ${ }^{17}$ Maranhão's population as estimated by Oliveira was 160,000 people, brought to 200,000 people by his "correction" (with 133,332 slaves). This number shows Maranhão with the largest share of slaves with respect to the total population in Brazil: 66.7 percent. Such a high figure led some authors, such as José Jobson de Arruda, to regard it as an indicative of the high income per capita in Maranhão after the cotton boom years. ${ }^{18}$ Other provinces that had large slaveholdings, such as Bahia, Rio de Janeiro, and Minas Gerais, all had shares of around 30 percent. The unusually high share of slaves in the overall population of Maranhão has raised further questions concerning the mismatch between slave imports and the subsequent decline of the slave population in the province. Daniel Silva, in a study on the Atlantic slave trade to Maranhão, compares the high slave population from 1819 with a much lower number of 97,132 slaves for $1823 .{ }^{19}$ Silva argues that the decline in the slave population could possibly be attributed not only to negative population growth rates, but also have been associated with slave exports from Maranhão to other provinces. When the British attempted to suppress the slave trade on the Brazilian coast, the port of São Luís could have been used as an intermediate source for other major ports in Brazil. $^{20}$

\footnotetext{
${ }^{17}$ Another common population source is the one from Oliveira Vianna, "Resumo Histórico dos Inquéritos Censitários no Brasil," which presents data for 1823. His figures, used by Stein (vassouras), presents even higher slaves populations for Bahia and Pernambuco. BA PE MA would have 42 percent of slaves.

${ }^{18}$ Arruda, O Brasil no comércio colonial, 540.

${ }^{19}$ Daniel B. Domingues da Silva, "The Atlantic Slave Trade to Maranhão, 1680-1846: Volume, Routes and Organisation," Slavery \& Abolition 29, no. 4 (December 1, 2008): 477-501, doi:10.1080/01440390802486507. His numbers are from Oliveira Vianna.

${ }^{20}$ Ibid., 483.
} 
Other estimates, however, raise doubts about the accuracy of Oliveira's high numbers for slaves in Maranhão. Stuart Schwartz, for example, argues that by 1820 Bahia represented the upper level of median and mean size of slaveholding, and that sugar plantations had the highest demand for slave labor. ${ }^{21}$ Francisco Mesquita lists a population of 76,500 slaves out of 150,000 inhabitants in Maranhão in 1821.22 The data he provides for 1800 and 1840 also reinforces the argument that the estimate presented by Oliveira overstates the slave population by a large margin: there were 34,800 slaves in a total population of 80,000 in 1800 , while the numbers in 1840 were 111,905 and 217,024 , respectively. ${ }^{23}$ Within the space of forty years, these figures suggest an increase of 2.2 percent a year for the free population and 2.9 percent for the slave population, a different trend from the one presented by Silva and other authors who used Oliveira's figures. ${ }^{24}$

Given the differences in population estimates, Table 6.2 presents some sources that contain information for Maranhão up until the official census of 1872. Most of the data was based on an 1870 study by Joaquim Norberto da Souza e Silva, with three exceptions: the population maps of 1798,1821 , and $1838 .{ }^{25}$ These three maps are much more detailed than many estimates presented by Souza e Silva, as some of them are only extrapolations from previous information or plain speculation. ${ }^{26}$

Data for 1798 are from a population map sent by Governor D. Diogo de Sousa to the Navy and Overseas State Secretary of Portugal in 1799. ${ }^{27}$ Unlike the data gathered by Oliveira, this map includes data on children under seven years of age. Moreover, it also includes those of the indigenous population which were considered "domesticated" - i.e., who lived in villages controlled in some way by the government. Figures for the "wild Indians" were acknowledged to be much higher, and Oliveira stated that they could reach 100,000 people in Maranhão. ${ }^{28}$

\footnotetext{
${ }^{21}$ Stuart B. Schwartz, "Patterns of Slaveholding in the Americas: New Evidence from Brazil," The American Historical Review 87, no. 1 (1982): 75, doi:10.2307/1863308.

${ }^{22}$ Mesquita, Vida e morte da economia algodoeira do Maranhão, 130.

${ }^{23}$ Mesquita also argues that, for the year 1822, "several sources" exist for the population of Maranhão. While not explicit about the sources, he mentions that one of them register the population for 1822 at 260.000 , a figure even higher than the one presented by Oliveira.

${ }^{24}$ Silva, "The Atlantic Slave Trade to Maranhão, 1680-1846."

${ }^{25}$ Silva, Investigações Sobre Os Recenseamentos Da População Geral Do Império E de Cada Província de per Si Tentados Desde Os Tempos Coloniais Até Hoje.

${ }^{26}$ Recenseamento do Brasil, 1920, Resumo Histórico Dos Inquéritos Censitários Realizados No Brasil, Ed. facsimilada (São Paulo: Instituto de Pesquisas Econômicas, 1986), 178.

27 “OFÍCIO Do Governador E Capitão Do Maranhão E Piauí, D. Diogo de Sousa Para O Secretário de Estado Da Marinha E Ultramar, D. Rodrigo de Sousa Coutinho."

${ }^{28}$ Velloso de Oliveira, "A Igreja Do Brasil."
} 
Table 6.2 - Population estimates for Maranhão, 1798-1872

\begin{tabular}{lccccl}
\hline Dates & Free & Slaves & Total & Slave Share & Source \\
\hline 1798 & 41,787 & 41,883 & 83,620 & 50.1 & See text \\
1819 & 66,668 & 133,332 & 200,000 & 66.7 & Oliveira \\
1821 & 68,100 & 84,534 & 152,893 & 55.3 & Lago \\
1825 & & 200,000 & & J. P. C. Giraldes \\
1830 & & $80-90,000$ & & & Joaquim Oliveira \\
1838 & 103,081 & 111,905 & 214,986 & 52.1 & See text \\
1841 & 105,119 & 111,905 & 217,000 & 51.1 & Report Miranda \\
1845 & & 200,000 & & Dictionary H G B \\
1847 & & $250-300,000$ & & Report Franco de Sá \\
1856 & & 360,000 & & Candido Machado \\
1864 & & 384,577 & 13.0 & Almanak Maranhão \\
1867 & & 50,000 & & & Souza Brazil \\
1872 & 284,101 & 74,939 & 359,040 & 20.9 & Census \\
\hline
\end{tabular}

Sources: See text.

For the year 1821, information is provided by Antônio Pereira do Lago, who worked in Maranhão gathering social and economic data. ${ }^{29}$ One limitation of his statistics is the absence of children under five years of age, which partially explains why the numbers in Table 6.4 show no growth in the white population between 1798 and 1821. Lago wrote that immigration largely increased the "white class" in Maranhão after 1808. Immigrants usually arrived in Brazil married and at a young age, so one can assume that their families would have grown. Lago states that he had a hard time finding out the exact number of slaves, which suggests that the numbers for captives were probably underestimated. ${ }^{30}$ If the percentage of children under five from the 1798 population map is used to complement Lago's estimates, the result for 1821 is a population of 169,607 - with 75,795 free and 92,446 slaves. This number for slaves is similar to the number given for 1823 by Oliveira Vianna. ${ }^{31}$

The statistical map of 1838 is based on a survey conducted by Manoel Joze de Medeiros and published in the province's Presidential report of $1841 .^{32}$ This report noted that Medeiros' estimation had limitations because some slaves were declared as free men so their owners could avoid being taxed when selling them to other provinces. ${ }^{33}$ Here, also it can be assumed that their

\footnotetext{
${ }^{29}$ Lago, Estatística histórico-geográfica da província do Maranhão.

${ }^{30}$ Ibid., 23.

${ }^{31}$ Stanley J. Stein, Vassouras, a Brazilian Coffee County, 1850-1900: The Roles of Planter and Slave in a Plantation Society (Princeton University Press, 1985), 296.

32 "Discurso Recitado Pelo Exm. Snr. Doutor João Antonio de Miranda, Prezidente Da Provincia Do Maranhão, Na Abertura Da Assemblea Legislativa Provincial” (Maranhão, July 3, 1841), Center for Research Libraries, Global Resources Network, http://brazil.crl.edu/bsd/bsd/340/.

${ }^{33}$ Ibid., 38.
} 
numbers are underestimated. Even Maranhão's president João Miranda stated that the total population figures seemed too small, and mentioned "free Africans" that did not appear in civil and parish records. Moreover, no age information is available, so it is not possible to know if the Medeiros' report included children.

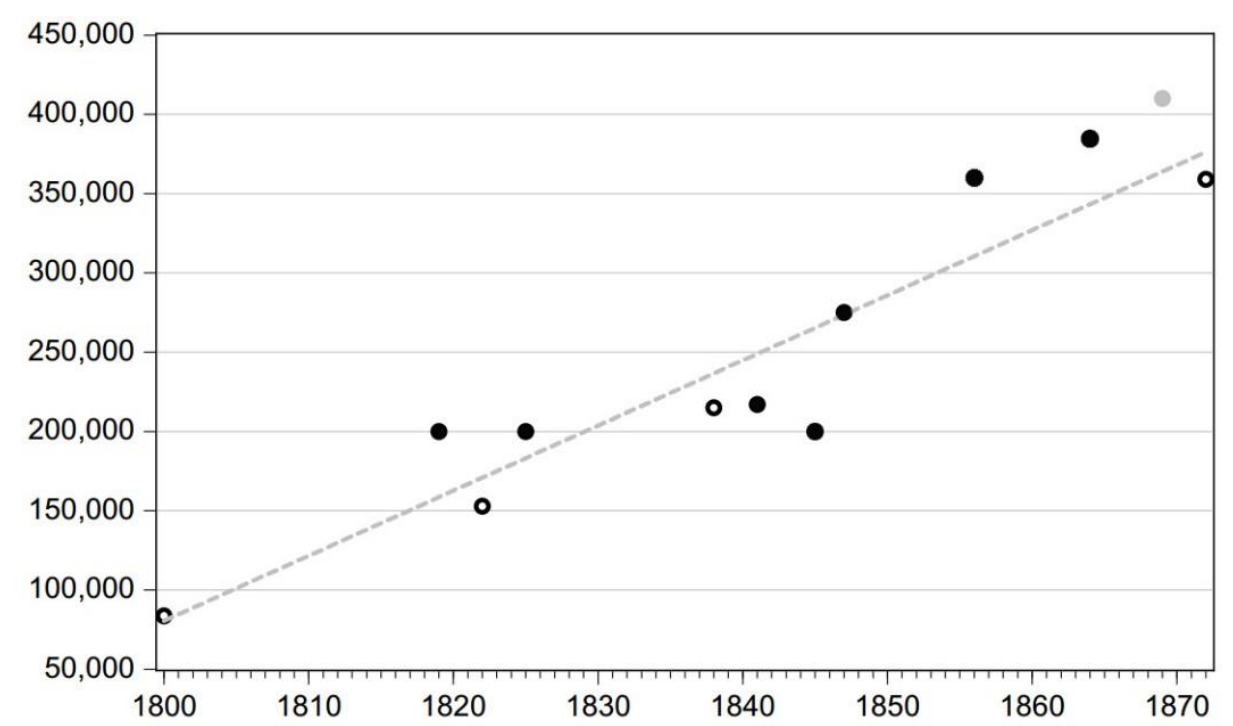

Figure 6.1 - Population estimates for Maranhão, 1800-1872

Sources: See Table 2.

Figure 6.1 plots a linear trend between the estimates presented in Table 6.2 to check if the population maps from 1798, 1821, and 1838, are not outliers. These maps, along with the 1872 census, which serves as a benchmark for the trend, are represented by empty dots in the figure. The population maps for Maranhão seem to be consistent across time. The light gray dot, not included in the linear trend, is an 1869 population estimate provided by Thomaz Pompeu de Souza Brazil that overstated the total population. The problem is that Souza Brazil's estimation was used by some important works, such as Robert Conrad's “The Destruction of Brazilian Slavery." ${ }^{34}$ As will be shown below, Souza Brazil's figures also overstate the slave population in other provinces, such as Pernambuco, thus posing a limitation on Conrad's argument for the decline in the numbers of slaves in the northeast after 1850.

Before analyzing the population maps for Maranhão in detail, it is important to compare its population statistics with other provinces to verify if slave numbers are consistent across regions. In addition, the slave share in the population is a rough measure of economic activity in provinces with large presence of export plantations. Maranhão can be compared with other

\footnotetext{
${ }^{34}$ Robert Edgar Conrad, The Destruction of Brazilian Slavery, 1850-1888 (University of California Press, 1972).
} 
cotton plantation areas in Brazil, such as Pernambuco, and the southern states in the United States. Table 6.3 presents population data for Pernambuco.

Table 6.3: Population estimates for Pernambuco, 1810-1872

\begin{tabular}{|c|c|c|c|c|c|}
\hline Dates & $\begin{array}{c}\text { Free } \\
\text { Population }\end{array}$ & $\begin{array}{c}\text { Slave } \\
\text { Population }\end{array}$ & Total & Slave Share & Source \\
\hline 1810 & & & 274,687 & & \\
\hline 1814 & & & 294,973 & & \\
\hline 1815 & & & 339,788 & & \\
\hline 1819 & 273,832 & 97,633 & 371,465 & 26.3 & Oliveira \\
\hline 1823 & 330,000 & 150,000 & 480,000 & 31.3 & Eisenberg \\
\hline 1826 & & & 287,110 & & \\
\hline 1827 & & & 450,000 & & \\
\hline 1829 & 208,832 & 80,265 & 287,140 & 28.0 & Eisenberg \\
\hline 1832 & & & 550,000 & & \\
\hline 1838 & 221,143 & 68,458 & 289,601 & 23.6 & Pres. Report 1841 \\
\hline $1838 b$ & 473,500 & 146,500 & 620,000 & 23.6 & Eisenberg \\
\hline 1842 & 498,526 & 146,398 & 644,924 & 22.7 & \\
\hline 1844 & 600,020 & 400,013 & $1,000,033$ & 40.0 & Souza Brazil \\
\hline 1845 & & & 320,000 & & \\
\hline 1855 & 548,450 & 145,000 & 693,450 & 20.9 & Eisenberg \\
\hline 1858 & & & $1,180,000$ & & \\
\hline 1864 & $1,040,000$ & 260,000 & $1,200,000$ & 21.7 & Souza Brazil \\
\hline 1872 & 752,511 & 89,028 & 841,539 & 10.6 & Census \\
\hline
\end{tabular}

Sources: See text.

One limitation of Pernambuco's statistics is that there is no population map comparable to Maranhão. A similar document, highlighted as a grey dot in Figure 6.2, clearly underestimates the population for 1838 . The other estimate for 1838 on the graph reinforces the argument that the former document does not contain the entire population. In addition to the 1838 population maps, two other observations are not used in the trend (also in gray): Souza Brazil's data from 1844 and $1864 .{ }^{35}$ As argued before, Souza Brazil's data is included in the figure because Robert Conrad used it to show the sharp decline of the slave population in the northeast after $1870 .{ }^{36}$ Conrad's source is a book by Agostinho Perdigão Malheiro, published in 1867, which draws on data from Souza Brazil. ${ }^{37}$ To calculate the population between 1844 and 1864, Souza Brazil used the population in 1815 estimated by Jeronymo M. Figueira de

\footnotetext{
${ }^{35}$ The facsimile source states that the data from Souza Brazil is for the year 1869, but that is probably incorrect, since Malheiros' book if from 1867. See Recenseamento do Brasil, 1920, Resumo Histórico Dos Inquéritos Censitários Realizados No Brasil, 411.

${ }^{36}$ Conrad, The Destruction of Brazilian Slavery, 1850-1888, 208.

${ }^{37}$ Agostinho Marques Perdigão Malheiro, A escravidão no Brasil : ensaio historico-juridico-social, vol. 3 (Rio de Janeiro: Typographia Nacional, 1867), 208, http://www2.senado.leg.br/bdsf/handle/id/174437.
} 
Mello, and with Malthus' assumption that population in a "young" country doubles every 25 years, arrived at the numbers for both years. ${ }^{38}$ Thus, Souza Brazil's estimates for Pernambuco in 1864 are an extrapolation from fifty years earlier.

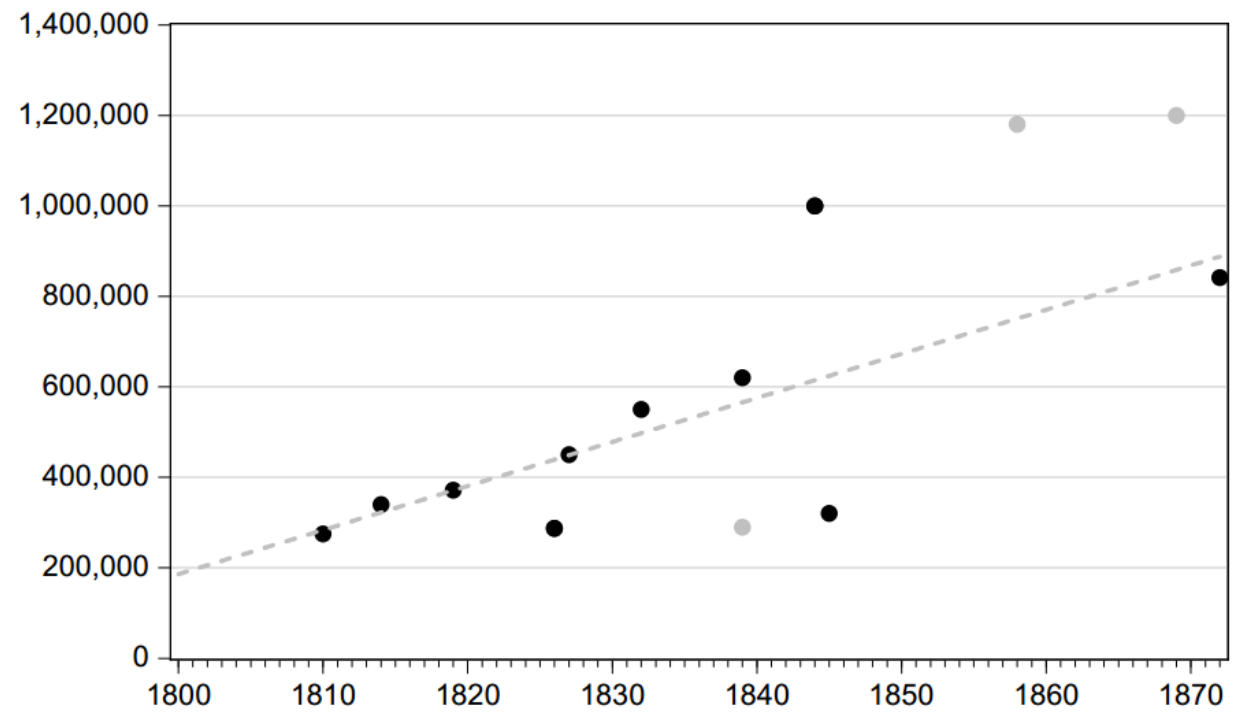

Figure 6.2 - Population estimates for Pernambuco, 1810-1872.

Sources: See Table 3

According to the estimations presented in Figure 6.2, slaves made up about 30 percent of Pernambuco's total population by 1820 , declining to 20 percent during the late 1840s. This implies that Maranhão had a considerably higher share of slaves (50 percent) than Pernambuco before 1850. These aggregate comparisons, nonetheless, do not allow us to infer that cotton production between Maranhão and Pernambuco involved a different number of slaves, as sugarcane was the main economic activity in Pernambuco.

\subsection{Comparison between populations}

Table 6.4 presents the population maps of Maranhão, parts of Pernambuco, and Alagoas, along with a census for Rio de Janeiro. ${ }^{39}$ Rio de Janeiro, with its coffee economy, was the most important export economy in Brazil during the first half of the nineteenth century and had a high demand for slave labor. It is expected, therefore, that its relative slave population was among the highest in Brazil. The reason I use the incomplete maps of Pernambuco and Alagoas is that there is an absence of similar documents for Brazilian cotton regions to compare with Maranhão. Despite not including the entire population, the share of slaves in Pernambuco

\footnotetext{
${ }^{38}$ Malthus example was for the United States.

${ }^{39}$ Silva, Investigações Sobre Os Recenseamentos Da População Geral Do Império E de Cada Província de per Si Tentados Desde Os Tempos Coloniais Até Hoje, 87. The population in table 4 does not contain the city of Rio de Janeiro, which had 137,078 people.
} 
is comparable to other estimates presented in Table 5.3. The data for Alagoas relates to the region of Penedo, which exported cotton through ports in Bahia. ${ }^{40}$

Table 6.4 - Population of Maranhão, Pernambuco, Rio de Janeiro, and Alagoas, 1798-1840

\begin{tabular}{|c|c|c|c|c|c|c|}
\hline & \multicolumn{3}{|c|}{ Maranhão } & \multirow{2}{*}{$\begin{array}{r}\mathrm{PE}^{*} \\
1838\end{array}$} & \multirow{2}{*}{$\begin{array}{r}\text { RJ } \\
1840\end{array}$} & \multirow{2}{*}{$\begin{array}{l}\mathrm{AL}^{*} \\
1838\end{array}$} \\
\hline & 1798 & 1821 & 1838 & & & \\
\hline Free Population & 41,787 & 68,100 & 103,081 & 213,046 & 183,190 & 28,441 \\
\hline White & 24,073 & 23,994 & 40,114 & 88,593 & 112,983 & 7,997 \\
\hline Indians & 4,094 & 9,687 & 14,476 & 2,094 & 5,615 & 332 \\
\hline Black & 1,332 & 9,308 & 13,782 & 17,821 & 13,387 & 2,294 \\
\hline Mulatto & 12,288 & 25,111 & 34,709 & 102,593 & 51,205 & 17,818 \\
\hline Slaves & 41,883 & 84,534 & 111,905 & 68,458 & 224,012 & 4,213 \\
\hline Black & 30,635 & 77,954 & 95,656 & 50,473 & 210,885 & 2,312 \\
\hline Mulatto & 11,198 & 6,580 & 16,249 & 7,381 & 13,127 & 1,901 \\
\hline Share of Slaves & 50.09 & 55.38 & 51.56 & 23.64 & 55.01 & 12.90 \\
\hline Total Pop. & 83,620 & 152,634 & 214,986 & 289,601 & 407,202 & 32,654 \\
\hline
\end{tabular}

Sources: 1798: Mapa... AHU; 1821: Lago; 1838: Relatório Presidente da Província 1841. *Not total population.

Maranhão had a share of slaves higher than the average of other provinces. In Pernambuco, as stated above, slaves represented 30 percent of the overall population in the 1820 s, declining to 20 percent around 1840 . To broaden the comparison, elsewhere in 1830 , in Minas Gerais and São Paulo, 36 percent of the population were slaves. ${ }^{41}$ The high proportion of slaves in Maranhão is most surprising around 1840, when Rio de Janeiro's coffee economy was growing fast and sugar production in Pernambuco was on its way to overtaking Bahia's output. ${ }^{42}$ This is a period, after all, that the crisis in the cotton sector led local newspapers in Maranhão to describe the financial condition of the province as "calamitous."43

The region of Penedo in Alagoas had 12.9 percent of slaves, almost half of them mulattos, indicating that the region was not part of the transatlantic slave trade. Rio de Janeiro, by contrast, was highly active in the slave trade, and only 6.2 percent of the slaves were mulattos. Maranhão and Pernambuco had similar shares of enslaved mulattos, at 16.9 and 14.6 percent, respectively. Table 6.4 also confirms a well-known characteristic of Brazilian slavery;

\footnotetext{
${ }^{40}$ Mariza de Carvalho Soares and Priscilla Leal Mello Mello, “'O resto predeu-se’? História e Folclore: O Caso dos Muçulmanos das Alagoas," in Visibilidades negras (UFAL, 2006), 19; Louis-François Tollenare, Notas dominicaes tomadas durante uma residencia em Portugal e no Brasil nos annos 1816, 1817 e 1818 (Impreza do Jornal do Recife, 1905). Also, local prices for Bahia in the Jornal do Commercio (August 30, Vol 1 N.14 Ed.14B 1830 p.3) reported "cotton from Alagoas."

${ }^{41}$ Luna and Klein, "Slave Economy and Society in Minas Gerais and São Paulo, Brazil in 1830," 10.

${ }^{42}$ Stein, Vassouras, a Brazilian Coffee County, 1850-1900, 53; Klein and Luna, Slavery in Brazil, 85.

${ }^{43}$ Viveiros, História do comércio do Maranhão, 1:154.
} 
the high numbers, especially when compared to the United States, of free blacks and mulattos. ${ }^{44}$ The number of free colored in the Brazilian population were so strikingly high that in many regions, their population was larger than the white population. ${ }^{45}$ The difference was a direct result of high manumission rates, considered an important aspect of the natural decline of the slave population in Brazil and some Caribbean states, such as Cuba. ${ }^{46}$ Pernambuco and Alagoas had higher shares of free non-whites - 42 and 62 percent, respectively. Again, Maranhão seemed more comparable to Rio de Janeiro than other northeast provinces, with a total population share of 22.5 percent of free non-whites. Henry Koster, who traveled in Brazil at the beginning of the nineteenth century, noted that in São Luís the black population was "much more considerable than at Pernambuco." ${ }^{47}$

Maranhão's cotton economy not only had a percentage of slaves comparable to the coffee region of Rio de Janeiro, but it also had a share similar to that of the cotton regions in the United States. The high share of slave labor in Maranhão seems to contradict the argument that competition from sugar plantations for workers was an important factor that limited the expansion of cotton production in Brazil. ${ }^{48}$ Comparing Brazil's coffee regions and the U.S. cotton south, Richard Graham argued that the labor supply between them was radically different. In addition to the difference in the population share of free blacks and mulattos, the South had more slaves than Brazil, and they formed a much larger proportion of the population. ${ }^{49}$ However, Graham's comparison was based on the 1860 U.S. census and Brazil's 1872 census. Table 6.5 shows the slave population of Alabama, Mississippi, and Louisiana during the same decades presented in the previous section for cotton production in Brazil. From these numbers, it emerges that Maranhão had a higher slave population than all the new cotton South in 1820. Moreover, since the figures for Maranhão's population in 1821 do not include children under the age of five, the number of slaves could have been ten percent higher, as will be shown in the next section.

\footnotetext{
${ }^{44}$ David Brion Davis, The Problem of Slavery in the Age of Emancipation, First Edition edition (New York: Knopf, 2014), 52.

${ }^{45}$ Stanley Engerman, “40 Years of Slavery Studies," História Econômica \& História de Empresas 18, no. 1 (November 13, 2015).

${ }^{46}$ Bergad, The Comparative Histories of Slavery in Brazil, Cuba, and the United States, 104; Engerman, "40 Years of Slavery Studies."

${ }^{47}$ Henry Koster, Travels in Brazil (London: Longman, Hurst, Rees, Orme, and Brown, Paternoster-Row., 1816), 166.

${ }^{48}$ Beckert, Empire of Cotton; Mann, The Cotton Trade of Great Britain.

${ }^{49}$ Graham, "Slavery and Economic Development," 634.
} 
Table 6.5 - Population of the United States South, 1800-1840

\begin{tabular}{lrrrrrr}
\hline \multirow{2}{*}{ Old South } & \multicolumn{3}{c}{ South Carolina } & \multicolumn{3}{c}{ Georgia } \\
& 1800 & 1820 & 1840 & 1800 & 1820 & 1840 \\
\hline Free Population & 199,440 & 244,266 & 267,360 & 103,280 & 191,333 & 410,448 \\
White & 196,255 & 237,440 & 259,084 & 101,678 & 189,566 & 407,695 \\
Black & 3,185 & 6,826 & 8,276 & 1,019 & 1,763 & 2,753 \\
Slaves & 146,151 & 258,475 & 327,038 & 59,406 & 149,656 & 280,944 \\
Share of Slaves & 42.3 & 51.4 & 55.0 & 36.5 & 43.9 & 40.6 \\
Total Pop. & 345,591 & 502,741 & 594,398 & 162,686 & 340,989 & 691,392 \\
\hline \multirow{2}{*}{ New South } & \multicolumn{7}{c}{ Alabama } & \multicolumn{7}{c}{ Mississippi } & Louisiana \\
\cline { 2 - 8 } & 1820 & 1840 & 1820 & 1840 & 1820 & 1840 \\
\hline Free Population & 86,022 & 337,224 & 42,634 & 180,440 & 84,343 & 183,959 \\
White & 85,451 & 335,185 & 42,176 & 179,074 & 73,383 & 158,457 \\
Black & 571 & 2,039 & 458 & 1,366 & 10,476 & 25,502 \\
Slaves & 41,879 & 253,532 & 32,814 & 195,211 & 69,064 & 168,452 \\
Share of Slaves & 32.7 & 42.9 & 43.5 & 52.0 & 45.0 & 47.8 \\
Total Pop. & 127,901 & 590,756 & 75,448 & 375,651 & 153,407 & 352,411 \\
\hline Source Cart
\end{tabular}

Source: Carter et al., Historical Statistics of the United States

One must be careful, however, when using aggregate population statistics to compare regions in the United States and Brazil. Unlike Brazil, where slave labor was dispersed across multiple activities during the first decades of the nineteenth century, in the United States slavery was strongly associated with commercial production. ${ }^{50}$ As an example, the slave population of the cotton-growing regions in Alabama was 46.4 percent of the total population in 1820 , a proportion higher than the share presented in Table 6.5. The Natchez region - in Mississippihad a slave share of almost 60 percent. ${ }^{51}$ In 1852, the American government compiled a survey of the number of slaves employed in cotton production in different states and the result ranged from 20 percent in South Carolina and Louisiana, to 50 percent in Alabama, Mississippi, and Georgia. $^{52}$

It is possible to make some inferences of how many slaves were employed in the cotton industry in Maranhão. According to Lago's data, 69,534 slaves (82 percent of the total slave population) worked in the agricultural sector in $1820 .{ }^{53}$ Lago does not provide details on the

\footnotetext{
${ }^{50}$ Gavin Wright, The Political Economy of the Cotton South: Households, Markets, and Wealth in the Nineteenth Century (Norton, 1978), chap. 3.

${ }^{51}$ Lewis Cecil Gray, History of Agriculture in the Southern United States to 1860, vol. 2 (Carnegie Institution of Washington, 1933), 903.

52 Thomas Ellison, A Handbook of the Cotton Trade: Or a Glance at the Past History, Present Condition, and Future Prospects of the Cotton Commerce of the World (London: Longman, Brown, Green, Longmans, and Roberts, 1858), 22.

${ }^{53}$ Lago, Estatística histórico-geográfica da província do Maranhão, 115.
} 
number of slaves in specific regions, but a local planter presented data for Ribeira do Itapecuru, the most important cotton-growing region in Maranhão. During the first decade of the nineteenth century roughly 13,500 people -16 percent of the population - lived in Ribeira, 85 percent of which were slaves, a third of the slave population of the province..$^{54}$

In addition to numbers for the total slave population, it is necessary to have data on slaveholding patterns in plantations across the Americas if we are to compare how planters in Brazil organized production. Cotton usually required less labor than sugar plantations, but it is also important to analyze if cotton plantations in Brazil used less labor than other cottonproducing regions, such as the United States. To illustrate, the British West Indies were known for having a high number of slaves working on plantations, with many sugar plantations having between 150 and 250 slaves. By contrast, the average cotton plantation in the southern United States had only between 20 and 50 slaves. ${ }^{55}$ Mota and Barroso show that between 1785 and 1824 most slaveowners had more than 20 slaves in the Ribeira do Itapecuru area, with a third of the sample having more than one hundred slaves per owner. ${ }^{56}$ These large slaveholdings, however, were distributed over more than one farm. ${ }^{57}$

Mota and Barroso's sample is limited - 33 slave-owners with a total of 2,958 slaves but nonetheless it is consistent with other studies arguing that typical cotton plantations in Maranhão and Pernambuco employed 50 slaves per unit, comparable to southern plantations in the United States. ${ }^{58}$ Louis-François Tollenare wrote in 1816 that the number of slaves on typical cotton plantations ranged between 10 to 30 , but he saw plantations with 100 to 150 slaves in Paraíba, and up to 300 in Ceará. ${ }^{59}$ However, remarks such as these, made by brief observations of large plantations, can be problematic. For example, Henry Koster reported in 1818 that he met merchants and planters in São Luís, and one of them, Simplicio Dias da Silva, owned between 1000 and 1500 slaves - a highly improbable number. Even with possible overstatements, the fact is that the average slaveholding pattern indicates that cotton planters in Maranhão had the necessary workforce to produce on a similar scale to the United States. In

\footnotetext{
${ }^{54}$ Gayoso, Compendio Historico-Politico Dos Principios Da Lavoura Do Maranhão, 164.

${ }^{55}$ Engerman, "40 Years of Slavery Studies," 102.

${ }^{56}$ Mota and Barroso, "Economia e demografia da escravidão no Maranhão e no Grão-Pará," 14.

${ }^{57}$ Antonia Da Silva Mota, "A Dinâmica colonial portuguesa e as redes de poder local na Capitania do Maranhão" (Universidade Federal de Pernambuco, 2007), 56, http://repositorio.ufpe.br:8080/xmlui/handle/123456789/7245.

${ }^{58}$ Klein and Luna, Slavery in Brazil, 68.

${ }^{59}$ Tollenare, Notas dominicaes tomadas durante uma residencia em Portugal e no Brasil nos annos 1816, 1817 e 1818,113
} 
1848 , after a decade of low international cotton prices, census sources show that 66 percent of the slave-owners in Maranhão still had 20 or more slaves. ${ }^{60}$

What is surprising is that during the early nineteenth century cotton did not have a smaller slaveholding pattern than sugar. Schwartz argued that slaveholding patterns in Bahia's Recôncavo were different from other sugar plantations in the Americas and, in 1818, 53 percent of slaves lived in groups of 1 to 20. This was a pattern normally associated with the United States than with the Caribbean. In Louisiana, in 1850, around 20 percent of slaves who worked on sugar plantations lived on estates with fewer than 50 workers. By contrast, in Jamaica, 11 percent lived in units of between 5 and 20 in 1832, and in Trinidad, 17 percent lived in units of under 20 in $1814 .{ }^{61}$ In their studies on Minas Gerais and São Paulo in the 1830s, Luna and Klein found only three owners in Minas who had more than 300 slaves, while the largest slave-owner in São Paulo had 164 slaves.. ${ }^{62}$

With regards to Pernambuco, Peter Eisenberg observes that travelers at the beginning of the nineteenth century reported that sugar production required 40 slaves, and large estates employed between 100 and 150 slaves, with some employing as many as 300. During the 1840s, the average number of slaves over 331 plantations was 55, whereas in the 1850 s, a survey of 532 plantations reported an average of 20 slaves. ${ }^{63}$ A census carried out in an important sugar production district in Pernambuco in 1857 found that, of 46 sugar mills, the average slaveholding was 72 - 37 percent had up to 50 slaves, 43.5 percent had between 50 and 100 , and 19.5 percent had more than 100 slaves. $^{64}$

Since studies for cotton regions in the United States usually define a plantation as having a workforce of 20 slaves or more, the evidence presented above shows that in the northeast of Brazil, cotton was not a crop produced by small independent farmers, as seems to be the case for the latter part of the nineteenth century. ${ }^{65}$ The most detailed evidence for cotton plantations, from Mota, suggests that slaveholding patterns in Maranhão were similar to those in the United

\footnotetext{
${ }^{60}$ Renato Leite Marcondes, "Posse de Cativos No Interior Do Maranhão (1848)," Revista Do Instituto Arqueológico, Histórico E Geográfico Pernambucano, no. 61 (July 2005): 183.

${ }^{61}$ Schwartz, "Patterns of Slaveholding in the Americas," 71.

${ }^{62}$ Luna and Klein, "Slave Economy and Society in Minas Gerais and São Paulo, Brazil in 1830."

${ }^{63}$ Eisenberg, The Sugar Industry in Pernambuco, 146.

${ }^{64}$ José Antônio Gonsalves de Mello, ed., O Diario de Pernambuco E a História Social Do Nordeste (18401889), vol. 2 (Recife: O Diario de Pernambuco, 1975), 448.

${ }^{65}$ Raymond C. Battalio and John Kagel, "The Structure of Antebellum Southern Agriculture: South Carolina, a Case Study," Agricultural History 44, no. 1 (1970): 26; Lewis Cecil Gray, History of Agriculture in the Southern United States to 1860, vol. 2 (Carnegie Institution of Washington, 1933), 481; Ulrich Bonnell Phillips and John David Smith, Life and Labor in the Old South (Columbia, S.C: University of South Carolina Press, 2007).
} 
States. The important difference between these regions was not in slaveholding patterns, but sources of slaves, which is discussed in the next section.

\subsection{Gender imbalances and population growth}

Although the slave population in Maranhão and Pernambuco grew at a significant rate during the first four decades of the nineteenth century, the continuous increase in labor supply was highly dependent on the slave trade. ${ }^{66} \mathrm{~A}$ higher death rate, combined with a lower birth rate than the national average, were two reasons that impaired the natural growth of the slave population. Harsh work and the higher susceptibility of foreign slaves to local diseases explained most of the variation in the death rates. Lower birth rates were connected to gender imbalances, which is a key difference between the history of slavery in Brazil and the United States. With the end of the slave trade in 1807, and with a lower death rate than in Brazil, in the United States the distribution of enslaved men and women was comparable to that of the free population. ${ }^{67}$ By contrast, Brazil had an active slave trade until 1850 but the slave population was predominantly male, so gender imbalance limited the possibilities for natural population growth. ${ }^{68}$

Analyzing Pernambuco's sugar economy, Peter Eisenberg also linked the negative growth rate of the slave population to conditions similar to those listed above: higher demand for men skewed gender distribution; enslaved women had children at a much lower rate than free women; and there was a high mortality rate among slave infants. ${ }^{69}$ One reason to compare gender distribution is that evidence suggests that sugar plantations represented a harsher reality for workers than the production of other commodities. In the British West Indies, where many islands produced sugar, cotton, and coffee, slaves employed in cotton or coffee had higher birth rates and lower mortality. ${ }^{70}$

Table 6.6 confirms previous findings regarding gender imbalances in Brazil's slave population. Compared to the cotton south in the United States, Maranhão had a higher share of males in its slave population, although gender imbalance was lower than in other parts of

\footnotetext{
${ }^{66}$ Klein and Luna, Slavery in Brazil, 149.

${ }^{67}$ Davis, The Problem of Slavery in the Age of Emancipation, 48.

${ }^{68}$ Bergad, The Comparative Histories of Slavery in Brazil, Cuba, and the United States, 43; Engerman, "40 Years of Slavery Studies."

${ }^{69}$ Eisenberg, The Sugar Industry in Pernambuco, 148.

${ }^{70}$ J. R. Ward, British West Indian Slavery, 1750-1834: The Process of Amelioration (Clarendon Press, 1988), 170-79.
} 
Brazil. ${ }^{71}$ The predominance of cotton plantations in Maranhão explains the lower gender imbalance, because there is evidence that female slave labor was more common in cotton than in other crops, such as sugar. ${ }^{72}$ In São Paulo and Minas Gerais around 1830, the average gender ratio beteen slaves was roughly 158 men for every 100 women, and in regions with more dynamic economic activities, this ratio increased to 180 men for every 100 women. ${ }^{73}$ Data for Maranhão shows a slave gender ratio of 126 men to 100 women during the first two decades of the nineteenth century. ${ }^{74}$ Since no distinction was made between blacks and mulattos, the gender inequality reported was analogous to the Province's average in 1798, which was 125.6. ${ }^{75}$

Table 6.6 - Sex ratio in Brazil and the United States, 1798-1840

\begin{tabular}{|c|c|c|c|c|c|c|}
\hline \multirow[t]{2}{*}{ Maranhão } & \multirow[t]{2}{*}{ White } & \multirow[t]{2}{*}{ Indian } & \multicolumn{2}{|c|}{ Mulatto } & \multicolumn{2}{|c|}{ Black } \\
\hline & & & Free & Slave & Free & Slave \\
\hline 1798 & 108 & 96 & 115 & 97 & 108 & 138 \\
\hline 1821 & 112 & 112 & 115 & 129 & 91 & 123 \\
\hline 1838 & 104 & 102 & 101 & 93 & 110 & 119 \\
\hline \multicolumn{7}{|l|}{ Pernambuco } \\
\hline 18291 & 110 & & & & & 162 \\
\hline 1838 & 74 & 98 & 95 & 91 & 92 & 139 \\
\hline $1842^{1}$ & 110 & & & & & 156 \\
\hline \multicolumn{7}{|l|}{ Rio de Janeiro } \\
\hline 1840 & 108 & 99 & 93 & 106 & 86 & 164 \\
\hline United States & $\begin{array}{l}\text { National } \\
\text { Average }\end{array}$ & Alabama & Georgia & Louisiana & Mississippi & S. Carolina \\
\hline 1820 & 105 & 108 & 103 & 113 & 106 & 102 \\
\hline 1840 & 100 & 101 & 98 & 106 & 101 & 94 \\
\hline
\end{tabular}

Sources: (1) Eisenberg, Modernização sem mudança, 150. U.S., Historical Statistics of the United States.

Negative population growth rates resulting from high death rates and gender imbalances demonstrate that a reduction in the captive population would have been inevitable without the transatlantic trade. One way to measure the effect of the transatlantic trade is to build a counterfactual showing what the size of the population would have been during the cotton boom

\footnotetext{
${ }^{71}$ Bergad (2007, p.109) quotes a study from Motta (1988) which presented a "slightly skewed" sex ratio toward males in 1798. While the data is from a São Paulo parish, the information does not seem to confirm Bergad statement. While the white sex ration was 120,8, the slave was 138,8. See José Flavio Motta, “A Família Escrava e a Penetração do Café em Bananal (1801-1829),' Revista Brasileira de Estudos Populacionais, Vol. 6 (1988), pp. 71-101.

${ }^{72}$ Flávio Rabelo Versiani and José Raimundo Oliveira Vergolino, "Posse de Escravos E Estrutura Da Riqueza No Agreste E Sertão de Pernambuco: 1777-1887," Estudos Econômicos (São Paulo) 33, no. 2 (June 2003): 367, doi:10.1590/S0101-41612003000200005; Robert William Fogel, Without Consent Or Contract: The Rise and Fall of American Slavery (Norton, 1994), 45.

${ }^{73}$ Luna and Klein, "Slave Economy and Society in Minas Gerais and São Paulo, Brazil in 1830," 12.

${ }^{74}$ Mota and Barroso, "Economia e demografia da escravidão no Maranhão e no Grão-Pará," 31.

${ }^{75}$ Gayoso, Compendio Historico-Politico Dos Principios Da Lavoura Do Maranhão, 164.
} 
years without the slave trade. Using the birth and death information from the 1798 population map, a simple linear model is used to calculate the population in 1821: $N_{t+l}=N_{t}+B_{t}-D_{t}+I_{t}$, in which population size $(N)$ at time $t+1$ is equal to the population size at time $t$ plus births $(B)$ minus deaths $(D)$ plus immigration $(I)$. For white immigrants, the only information that Lago presents is that they "increased after 1808." ${ }^{76}$ For slaves, the transatlantic traffic data are available from the Slave Voyages Database. ${ }^{77}$ In terms of natural population growth, the white population birth rate in 1798 was 26.32 per 1,000 persons, while the death rate was 16.27 per 1,000 persons. For black slaves, the birth rate was 21.41 and the death rate was 26.36 per 1,000. Since at the time the term "blacks" usually referred to people with African ancestry, the calculation including slave imports does not consider mulattos.

Table 6.7 show three estimates for the population in 1821: one using the linear model, one from Lago, and another using Lago's estimate with the addition of children under five, using the 1798 population map as a reference. In 1798, the share of children between zero and five was 11.1 percent: 11.3 for the free population, and 9.3 for the slaves. These numbers are consistent with other sources: at the beginning of the nineteenth century probate records from cotton plantations in Maranhão show that 13.2 percent of slaves were children below six years of age. ${ }^{78}$ Without the slave trade $(I=0)$, which brought in 41,634 slaves in these two decades, the slave population in 1821 would have been $27,323 .{ }^{79}$

Table 6.7 - Estimates for the population in Maranhão, 1821

\begin{tabular}{lccccc}
\hline & $\begin{array}{c}\text { Births per 1000 } \\
(1798)\end{array}$ & $\begin{array}{c}\text { Deaths per 1000 } \\
(1798)\end{array}$ & $\begin{array}{c}\text { Population } \\
\text { (Linear) }\end{array}$ & $\begin{array}{c}\text { Population } \\
\text { (w/children) }\end{array}$ & $\begin{array}{c}\text { Population } \\
\text { (Lago) }\end{array}$ \\
\hline White & 26.32 & 16.27 & 30,296 & 26,753 & 23,994 \\
Black & & & & & \\
$\quad$ Free & 60.81 & 67.57 & 1,340 & 10,524 & 9,308 \\
Slave & 21.41 & 26.38 & 65,926 & 85,749 & 77,954 \\
Mulatto & & & & & \\
Free & 39.06 & 17.17 & 20,220 & 28,752 & 25,111 \\
Slave & 19.91 & 15.00 & 12,534 & 11,541 & 6,580 \\
Total Free & & & 51,856 & 75,795 & 68,100 \\
Total Slave & & & 78,460 & 92,446 & 84,534 \\
\hline
\end{tabular}

Sources: See text.

\footnotetext{
${ }^{76}$ Lago, Estatística histórico-geográfica da província do Maranhão, 23.

77 "Voyages Database,” 2009, Voyages: The Trans-Atlantic Slave Trade Database, www.slavevoyages.org.

${ }^{78}$ Antonia Da Silva Mota, "A Dinâmica colonial portuguesa e as redes de poder local na Capitania do

Maranhão" (Universidade Federal de Pernambuco, 2007), 59.

79 "Voyages Database."
} 
It is therefore possible to conclude that without the transatlantic trade the slave population in 1821 would have been on average 65 percent lower than it was. Before presenting more information on the slave trade in Maranhão, let us turn to other trends that are noticeable from Table 6.7. First, a distinction between mulattos and blacks was probably introduced between the two periods, as many mulatto slaves seemed to have been classified as black in the 1798 population map. Table 6.4 also shows this change, indicating a sharp reduction in mulatto slaves in 1821. In addition, since free blacks represented only 1.5 percent of the population in 1798, births and deaths appear to be overestimated. ${ }^{80}$ One question which remains unresolved is whether the free black population had a positive natural growth rate or whether it had a natural negative rate, like the slave population. Lastly, the increase in mulatto and black free population across time is consistent with the findings of the literature, which states that the ability to buy their freedom - which was a major difference between Brazil and the former British colonies resulted in a higher number of free blacks in Brazil. ${ }^{81}$

The slave population continued to have negative growth rates and so the dependence on foreign labor continued during the following decades. After Brazil's slave trade came to an end in 1850 , the U.S. South was increasingly cited as a successful example of the possibility of a systematic "breeding" to offset declining slave population. ${ }^{82}$ Others were less optimistic: a local deputy from Maranhão wrote in 1856 that the "Virginia example" for increasing the slave population was unlikely to work in the province. Doubting the planters' capacity to organize such a scheme, the deputy saw the migration of slaves to coffee regions as the inevitable outcome. ${ }^{83}$

\subsection{The slave trade}

The establishment in 1755 of the Grão Pará and Maranhão Company, with its investment in cotton and rice plantations, made the Atlantic slave trade to Maranhão lucrative for the first time. ${ }^{84}$ Between 1760 and 1821, 80,084 slaves arrived in Maranhão through the transatlantic trade. This figure was much lower than the trade with Pernambuco, which received 192,081 slaves, and Bahia, which received 532,104. Nonetheless, the relative importance of the slave trade in Maranhão was larger because of the smaller size of its free population. Bahia was

\footnotetext{
${ }^{80}$ For the second half of the nineteenth century, general mortality did not decrease below 27 deaths per thousand in Recife. Eisenberg, The Sugar Industry in Pernambuco, 48.

${ }^{81}$ Bergad, The Comparative Histories of Slavery in Brazil, Cuba, and the United States, 48.

${ }^{82}$ Conrad, The Destruction of Brazilian Slavery, 1850-1888, 32.

${ }^{83}$ Conrad, The Destruction of Brazilian Slavery, 1850-1888.

${ }^{84}$ Carreira, A companhia geral do Grao-Para e Maranhao.
} 
also a 'distribution port' for other provinces, such as Minas Gerais, something which contributed to increase the number of arrivals.

Figure 6.3 shows the number of slaves that arrived in Maranhão. The higher number of arrivals between 1780 and 1820 is clearly related to the cotton export cycle. With the expansion of the coffee economy in the 1830s, demand for slaves grew faster than the Atlantic trade could supply. The result was the recruitment of the labor force from less productive regions in northeast Brazil. In 1841, a Presidential report from Maranhão stated that the reduction in the slave population was happening "with certainty." 85 The last arrival of slaves in Maranhão occurred in 1846 , with the following year registering the first export to other provinces. ${ }^{86}$

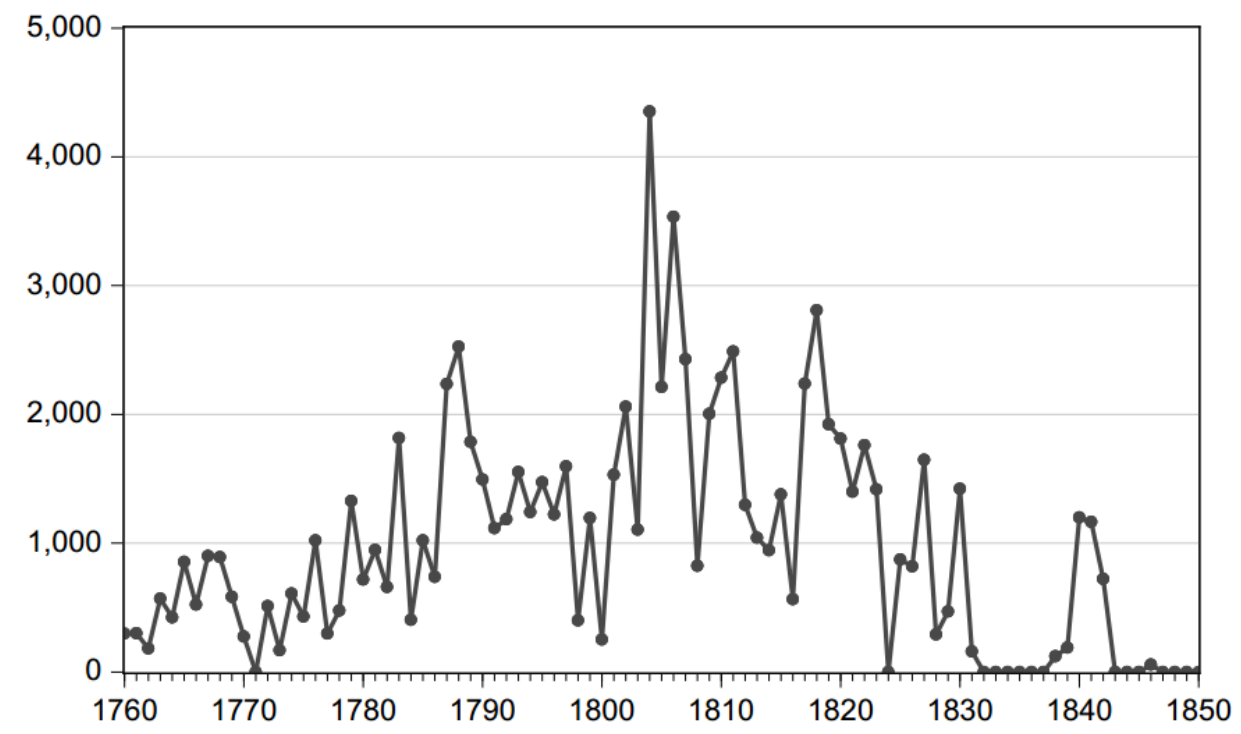

Figure 6.3 - Slave imports into Maranhão, 1760-1850

Source: The Trans-Atlantic Slave Trade Database (2009)

Despite the connection between the demand for slave labor and cotton exports, Figure 6.3 does not imply that the stagnation of exports was directly related to a reduction in the transatlantic slave trade. Slave arrivals through the Atlantic trade declined in other Brazilian regions after 1820, not only in Maranhão. ${ }^{87}$ There is evidence showing that the eagerness to buy slaves between 1815 and 1819, when cotton prices were high, led some planters to bankruptcy after cotton prices fell. ${ }^{88}$ With a reduction of 31 percent in imports and 38.5 percent in exports

\footnotetext{
${ }^{85}$ Provincial Presidential Reports - Maranhão, 1841, p.39. At the capital, there were 402 more deaths for slaves than the free population in 1840. In total, there were 1669 deaths at the capital in that year, a third between 1 and 10 years.

${ }^{86}$ Mesquita, Vida e morte da economia algodoeira do Maranhão, 130; Silva, "The Atlantic Slave Trade to Maranhão, 1680-1846."

${ }^{87}$ Klein and Luna, Slavery in Brazil, 77.

${ }^{88}$ Viveiros, História do comércio do Maranhão, 1:139.
} 
in 1821, the British consul in Maranhão reported that there was a scarcity of "ready cash" in the province, leading the slave dealers to extend credit to planters even more. ${ }^{89}$

The reduction in the slave trade after 1820 was not only associated with cotton prices, but also with a forced change in the African regions that supplied the slaves. Daniel Silva argues that the slave trade in Maranhão had a different pattern from the rest of Portuguese America, mainly because it was connected through different wind and ocean currents. ${ }^{90}$ The different route, similar to the Caribbean Islands, also connected Maranhão with different African sources, such as Upper Guinea. ${ }^{91}$ Contemporary reports confirm the predominance of slaves from northwest Africa at the end of the eighteenth century, and also show that slaves who arrived from Guinea were more expensive than those from Angola or Costa da Mina. ${ }^{92}$ Thus, the known triangle route between Lisbon, southern parts of the African continent, and Brazil was not the main route used in Maranhão. ${ }^{93}$ During the cotton boom years, vessels sailing from Lisbon between 1788 and 1815 transported nearly 82 percent of the slaves who arrived in São Luís.94

The signing of the 1815 treaty with Britain that prohibited the slave trade north of the Equator, and the loss of some African territories meant that Portuguese slave dealers were forced to change their trade routes..$^{95}$ The 1815 treaty prohibited the importation of slaves into Brazil under any but the Portuguese flag, which reinforced Portuguese dominance. ${ }^{96}$ In 1821 , Consul Robert Hesketh informed the British government that "the capital employed in the slave trade chiefly belongs to residents in Portugal." ${ }^{97}$ In addition, some well-known cotton planters in Maranhão, such as João Belford, appear on lists of slave vessel owners who sponsored voyages to Maranhão. ${ }^{98}$

\footnotetext{
89 "FO 63/249 - Consuls Alexander Cunningham, Robert Hesketh, and William Pennell, Etc. (Brazil)." 1822, 73, The National Archives, Kew.

${ }^{90}$ Silva, "The Atlantic Slave Trade to Maranhão, 1680-1846," 485.

${ }^{91}$ Walter Hawthorne, From Africa to Brazil: Culture, Identity, and an Atlantic Slave Trade, 1600-1830 (Cambridge; New York: Cambridge University Press, 2010).

${ }_{92}$ Gayoso, Compendio Historico-Politico Dos Principios Da Lavoura Do Maranhão, 243.

${ }^{93}$ Alencastro, $O$ Trato dos Viventes; João Fragoso, "Mercados e Negociantes Imperiais: Um Ensaio Sobre a Economia do Império Português (Séculos XVII e XIX)," História: Questões \& Debates 36, no. 1 (2002): 109, http://ojs.c3sl.ufpr.br/ojs/index.php/historia/article/view/2690.

${ }^{94}$ Silva, "The Atlantic Slave Trade to Maranhão, 1680-1846," 489.

${ }^{95}$ Leslie Bethell, The Abolition of the Brazilian Slave Trade: Britain, Brazil and the Slave Trade Question (Cambridge: Cambridge University Press, 1970), 1.

${ }^{96}$ Ibid., 18.

97 “'Consuls Alexander Cunningham, William Pennell, Robert Hesketh, John Lempriere, Cox, and John Parkinson, Etc. (Brazil), FO 63/240” 1821, fol. 202, The National Archives, Kew.

${ }^{98}$ For Lisbon's major merchants between 1790 and 1822, see: Jorge Miguel Viana Pedreira, "Os Homens de Negócio Da Praça de Lisboa de Pombal Ao Vintismo (1755-1822): Diferenciação, Reprodução E Identificação de Um Grupo Social" (FCSH, 1995).
} 
The 1807 British prohibition on British subjects trading in African slaves, which affected the Caribbean trade, also reduced the amount of slave supply through the sea routes used by Maranhão's merchants. ${ }^{99}$ The route change is described in a British consular report of 1822, according to which, of the 1,761 slaves who had disembarked in Brazil the previous year, 52 percent had come from Angola (or Benguela), and 18 percent from northwest regions of Africa. Approximately 30 percent of slaves imported into Maranhão came in ships from Rio de Janeiro, Bahia, and Pernambuco. ${ }^{100}$ Some years later, in 1826, the British consul in Maranhão reported that "all the slaves have arrived from Brazil Ports, and the chief part of them are Creole slaves from Ceará, whose masters were forced to bring them here for sale by the great want of provisions in that country." 101

After 1820, when Maranhão’s cotton economy began to stagnate, slave labor arrivals steadily declined with until a momentary reversal during the 1840s. Silva argues that this decline was in response to the "extension of British efforts to suppress the slave trade into the South Atlantic." 102 Yet, given the series of economic and political crises in Maranhão during the 1830s, British policies would seem a marginal reason for the decline in slave arrivals. For instance, the president of the province warned in 1831 that, with "trade paralysis," public revenues had dropped by almost one third. ${ }^{103} \mathrm{~A}$ year after that, the introduction of large quantities of counterfeit copper coins also had a negative effect on foreign trade. On the political side, the Cabanagem revolt, which began in the province of Pará in 1835, also affected commerce in nearby regions such as Maranhão. Newspapers reported in 1835 that rebels in Maranhão and Pará kept capturing regions and disrupting trade. ${ }^{104}$ In 1838, the Balaiada established a revolutionary provisional government in the city of Caxias, one of the most important cotton growing regions in Maranhão at the time.

Despite these political and economic events, the decrease in slave arrivals happened only decades after the stagnation of Maranhão's cotton plantations had begun. As mentioned before, local politicians and planters knew that the United States had managed to increase its slave population after the end of the slave trade. In addition, the first registered slave export to other provinces occurred in 1846, several years after the instabilities of the 1830 s. With these

\footnotetext{
${ }^{99}$ Ward, British West Indian Slavery, 1750-1834, 43.

100 "From H. Chamberlain (Brazil), FO 63/246" September 1822, fol. 176, The National Archives, Kew.

101 "FO 13/30 - Arthur Aston, Consuls John Parkinson and Robert Hesketh." 1826, 193, The National Archives, Kew.

102 Silva, "The Atlantic Slave Trade to Maranhão, 1680-1846," 483.

103 Viveiros, História do comércio do Maranhão, 1:177.

104 “Interior: Noticias Do Pará," Jornal Do Commercio, January 7, 1836, 4 edition, 1; "Pará," Echo Do Norte, October 18, 1835, Vol 2, N.6 edition, 1, Memória Digital, Biblioteca Nacional.
} 
different opportunities for slave demand across time, the next section presents slave-price data and shows that until 1820, slave prices in Maranhão were higher than in other Brazilian provinces. After 1820, consistent with movements in the export trade, prices converge to Brazil's average and, after 1831, a large aspect of the increase in slave prices was not a result of policy changes, but of increasing inflation.

\subsection{Slave prices}

Slave prices were a crucial factor for planters to consider when making investment decisions. Although complaints about high slave prices permeated public debate in the nineteenth century, evidence suggests that prior to the end of the slave trade, in 1850, slave ownership was affordable for people with moderate means. ${ }^{105}$ Recent literature points out that slave ownership was more equally distributed than previously thought, which reinforces the argument that slave prices at the beginning of the nineteenth century were not so high in real terms. ${ }^{106}$

In the early nineteenth century, newspapers reported that there had been talk about abolishing the slave trade since the 1810s, but as time passed by and no significant changes were made, their worries eased. In 1830, the editors of the Farol Maranhanse argued that those employed in the agricultural sector were "not persuaded that the slave trade abolition is real, since they have been hearing this for many years and [yet] haven't seen any change." ${ }^{107}$ A few months later, however, Brazil's monarch announced that the Brazilian slave trade was illegal and the government would take the necessary measures to stop the traffic - a statement that became law in $1831 .{ }^{108}$ The 1831 law, the first official decision to end the slave trade in Brazil, was one of a series of factors that could have affected slave prices between 1780 and 1860 . Before 1819, high cotton prices increased demand for labor and stimulated slave imports, but the rising demand from coffee regions and British pressure to abolish the slave trade meant that planters kept expecting future constraints in the labor supply.

How did these changes affect slave prices? In the absence of a reliable price index to account for inflationary shocks, Figure 6.4 compares nominal slave prices in Maranhão with

\footnotetext{
105 Schwartz, "Patterns of Slaveholding in the Americas," 76.

106 Klein and Luna, Slavery in Brazil; Schwartz, "Patterns of Slaveholding in the Americas"; Zephyr L. Frank, Dutra's World: Wealth and Family in Nineteenth-Century Rio de Janeiro (Albuquerque: University of New Mexico Press, 2004); Renato Leite Marcondes, Diverso E Desigual: O Brasil Escravista Na Década de 1870 (FUNPEC, 2009).

107 “Tráfico de Escravos,” Farol Marenhense, January 5, 1830.

108 Bethell, The Abolition of the Brazilian Slave Trade, 67.
} 
prices in different areas in Brazil to show that, despite economic dissemblance, regions across Brazil had similar trends in slave prices during the first half of the nineteenth century. ${ }^{109}$ For Maranhão, Minas Gerais, and Rio Grande do Sul, series are for men between 15 and 40 years of age, who usually achieved the highest prices. ${ }^{110}$ Information for Maranhão before 1831, which has 2,157 observations, is from Walter Hawthorne's Maranhão Inventories Slave Database, and after 1832, with just two observations, from Francisco Mesquita. ${ }^{111}$ In Mesquita's information, however, it is not clear they are for men in the age range used in the previous years. Prices for Pernambuco are decennial averages for the cotton region (Agreste) and include women, a fact which partially explains why prices are lower than the other provinces. ${ }^{112}$

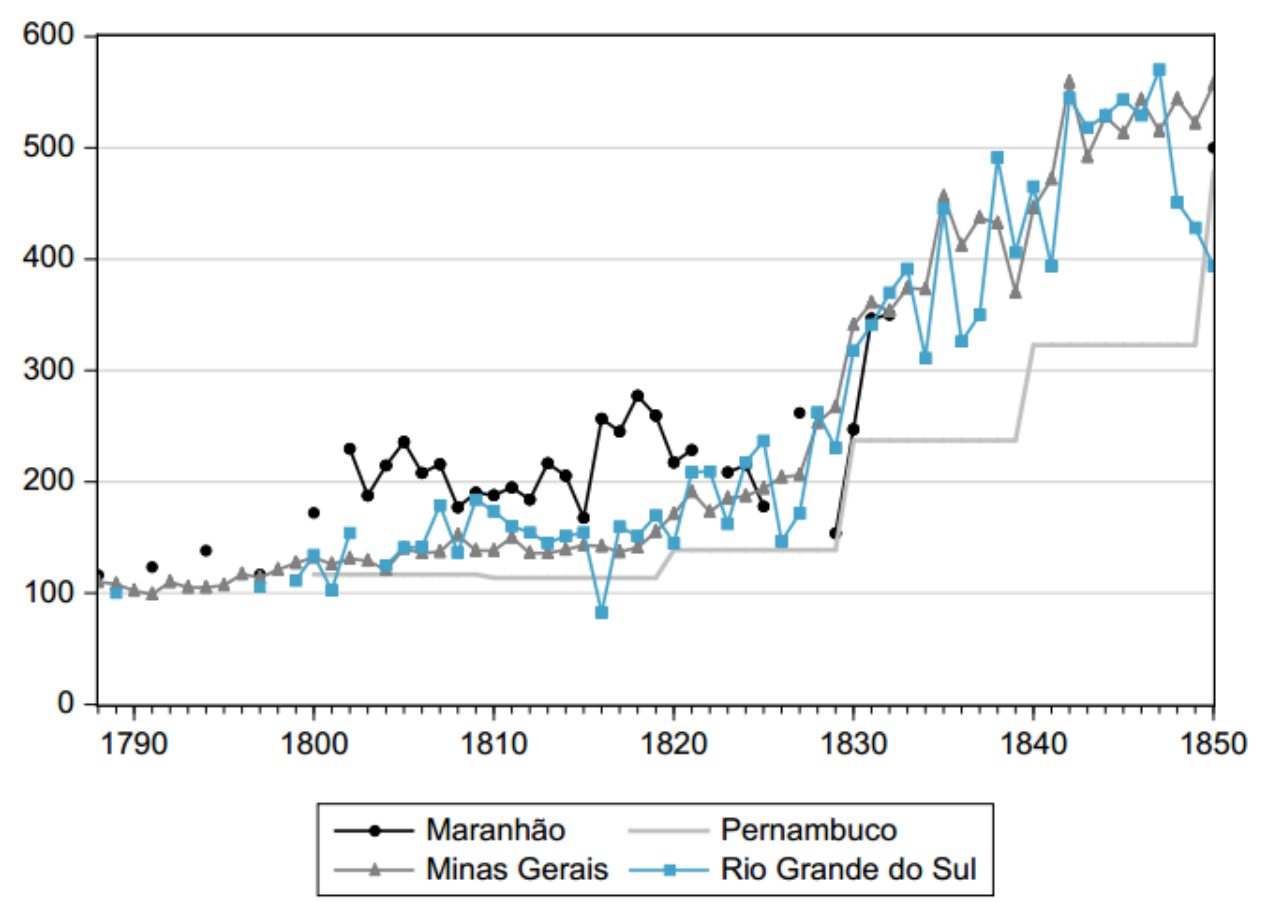

Figure 6.4 - Slave prices in Maranhão, Pernambuco, Minas Gerais, and Rio Grande do Sul (milréis)

Sources: MA (Hawthorne 2010; Mesquita, 1987; Mota, 2012); PE (Denslow, 1987; Resende et al, 2014); MG (Bergad, 1999); RS (Pereira, 2016)

\footnotetext{
${ }^{109}$ Bergad, The Comparative Histories of Slavery in Brazil, Cuba, and the United States; Thales A. Zamberlan Pereira, "Was It Uruguay or Coffee? The Causes of the Beef Jerky Industry's Decline in Southern Brazil (1850 1889)," Nova Economia 26, no. 1 (April 2016): 7-42, doi:10.1590/0103-6351/3005.

${ }^{110}$ Evidence suggests that slaved women worked in cotton sowing. Nevertheless, men represented the largest share of the field hands. See Camara, Memoria Sobre a Cultura Dos Algodoeiros E Sobre O Methodo de O Escolher, E Ensacar, 31.

${ }^{111}$ Hawthorne, From Africa to Brazil, 8; Mesquita, Vida e morte da economia algodoeira do Maranhão, 146. 112 Guilherme Resende et al., "Preços de Escravos E E Produtividade Do Trabalho Cativo: Pernambuco E Rio Grande Do Sul, Século XIX," Anais do XLI Encontro Nacional de Economia [Proceedings of the 41th Brazilian Economics Meeting] (ANPEC - Associação Nacional dos Centros de Pósgraduação em Economia [Brazilian Association of Graduate Programs in Economics], 2014), http://econpapers.repec.org/paper/anpen2013/030.htm.
} 
Figure 6.4 shows an integrated national slave market, with Minas Gerais and Rio Grande do Sul showing similar means and trends. ${ }^{113}$ Much of the short-term deviation can be explained by differences in sample size, as Bergad's series for Minas Gerais has 16,279 observations, while the price series for Rio Grande do Sul has 1,284. Pernambuco, even with lower prices, also exhibited similar trends: a slow increase until 1830, increasing more rapidly thereafter. During the first decade of the nineteenth century, slave prices in the Agreste region of Pernambuco were even higher than in other regions of the captaincy, attesting the importance of cotton exports at the time. However, between 1800 and 1820, when cotton exports were growing faster than slave supply, slave prices were higher in Maranhão than in other Brazilian regions. Higher demand and a different slave trade route (as mentioned in the previous section) explain why prices continued to be higher than Brazil's average. Higher prices are also consistent with the evidence that Maranhão did not export slaves to other provinces before the 1840s.

How did slave prices in Maranhão, which were higher than the Brazilian average, compare to international prices? Although using exchange rate conversion as a way to compare prices across economies with different living costs is limited, it can still provide us with useful information about general trends. ${ }^{114}$ Figure 6.5 shows that until 1810 , nominal slave prices in Maranhão were comparable to those in South Carolina - one of the first cotton states - and to average prices for slaves in New Orleans. These values are also consistent with other international markets at the time: data from the Caribbean show slave prices increasing from around $£ 60$ in 1795 to $£ 73$ in $1807 . .^{115}$

The series named "New Orleans Prime" in Figure 6.5 is a sample of men aged 18 to $30 .{ }^{116}$ Prices are higher because the age range is shorter than the samples used for Brazil and market prices were usually higher than those recorded in probate records. ${ }^{117}$ For example, data

\footnotetext{
${ }^{113}$ Information for Bahia and São Paulo also present similar prices, see Kátia M. de Queirós Mattoso, Herbert S. Klein, and Stanley L. Engerman, "Research Note: Trends and Patterns in the Prices of Manumitted Slaves: Bahia, 1819-1888," Slavery \& Abolition 7, no. 1 (May 1, 1986): 59-67, doi:10.1080/01440398608574903; Warren Dean, Rio Claro: A Brazilian Plantation System, 1820-1920 (Stanford University Press, 1976), 55.

114 Jeffrey G. Williamson, "Review Essay on British Economic Growth, 1270-1870; by Stephen Broadberry, Bruce M. S. Campbell, Alexander Klein, Mark Overton, and Bas van Leeuwen," Journal of Economic Literature 54, no. 2 (June 2016): 517, doi:10.1257/jel.54.2.514.

${ }^{115}$ David Eltis, Frank D. Lewis, and David Richardson, "Slave Prices, the African Slave Trade, and Productivity in the Caribbean, 1674-1807,” The Economic History Review 58, no. 4 (November 1, 2005): 679, doi:10.1111/j.1468-0289.2005.00318.x.

${ }^{116}$ Stanley Engerman, Richard Sutch, and Gavin Wright, "Slavery," in Historical Statistics of the United States, Millennial Edition On Line (Cambridge University Press, 2006), 372.

${ }^{117}$ Peter C. Mancall, Joshua L. Rosenbloom, and Thomas Weiss, "Slave Prices and the South Carolina Economy, 1722-1809," The Journal of Economic History 61, no. 03 (September 2001): 623.
} 
from a list of 1,546 slaves sold in São Luís in 1783, show that average market prices ranged from 135 to 160 mil-réis, with some slaves achieving 200 mil-réis. Planters in Maranhão wrote at the time that the lower prices in probate records - between 40 and 130 mil-réis - were used only on "court executions or adjudications to creditors."

Even with the difference in levels between the two New Orleans series, the trends are the same. There was volatility in the first two decades of the nineteenth century, first with the resumption of the slave trade in 1803 , and again when cotton prices increased after $1816 .{ }^{119}$ Prices increased again during the 1830 s, until the 1837 economic crisis. ${ }^{120}$ In 1836, a U.S. Treasury document about cotton stated that slave prices had almost doubled in the space of one decade, from $£ 94$ on average in the late 1820 s to $£ 185$ in $1836 .{ }^{121}$ In any case, during the first half of the nineteenth century as a whole, slave prices were fairly stable. In Cuba, slave prices also remained relatively constant between 1815 and 1850, even after the British slave trade came to an end in $1823 .^{122}$

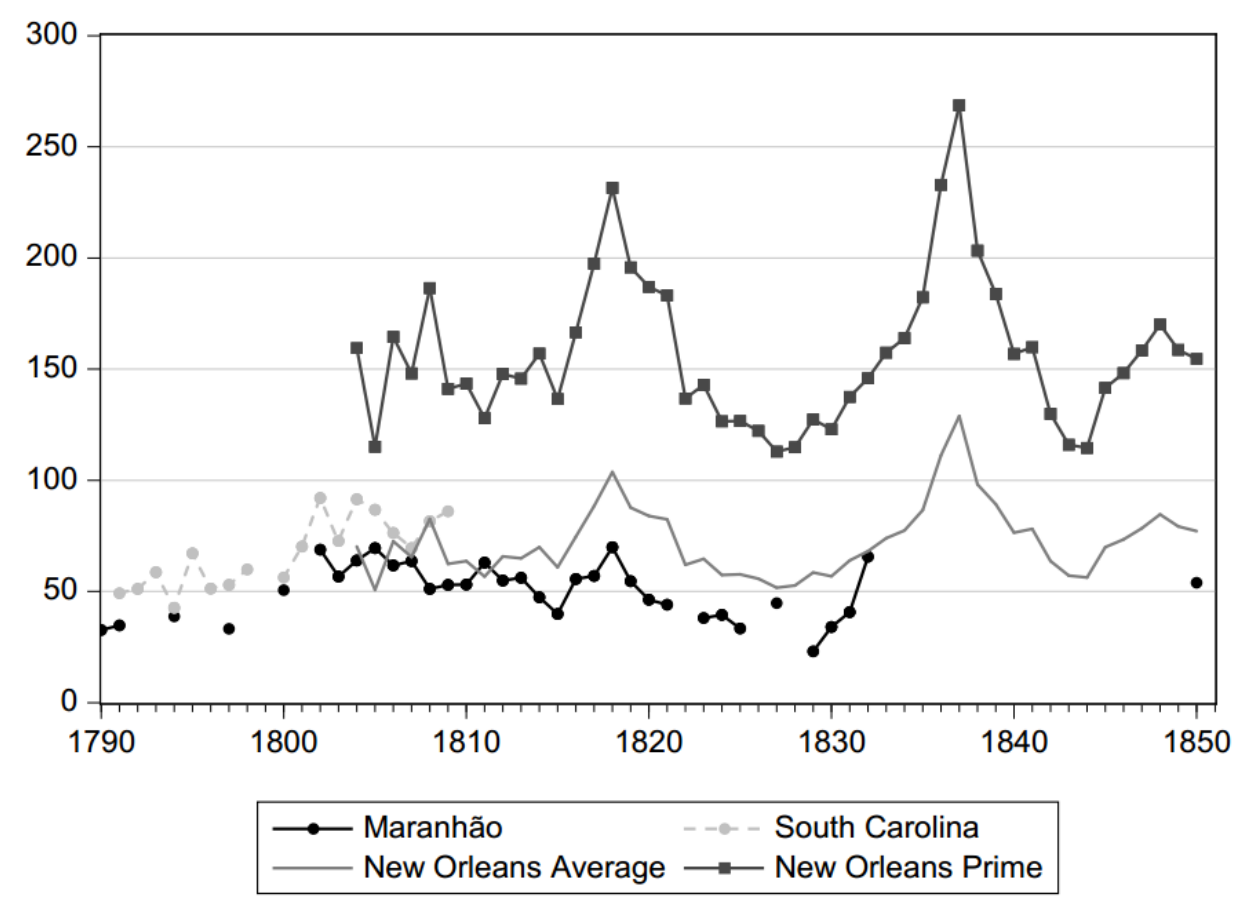

Figure 6.5 - Slave prices in South Carolina, New Orleans, and Maranhão (£)

\footnotetext{
118 Gayoso, Compendio Historico-Politico Dos Principios Da Lavoura Do Maranhão, 243.

119 Adam Rothman, Slave Country: American Expansion and the Origins of the Deep South (Harvard University Press, 2005), 87; Engerman, Sutch, and Wright, "Slavery," 372.

${ }^{120}$ Jessica M. Lepler, The Many Panics of 1837: People, Politics, and the Creation of a Transatlantic Financial Crisis (New York, NY: Cambridge University Press, 2013).

${ }^{121}$ Treasure Department, Letter from the Secretary of the Treasury, Transmitting Tables and Notes on the Cultivation, Manufacture, and Foreign Trade of Cotton. (Washington, D.C.: Gales \& Sraton, 1836), http://hdl.handle.net/2027/uc1.\$b674462.

${ }^{122}$ Laird W. Bergad, Fe Iglesias García, and María del Carmen Barcia, The Cuban Slave Market, 1790-1880 (Cambridge England; New York: Cambridge University Press, 1995), 48.
} 
Sources: MA (see Figure 4); SC (Mancal et al, 2001); New Orleans (Historic Statistics of the United States, table Bb210, Bb212).

The stability of slave prices in other American regions suggest that part of the increase in the Brazilian prices, especially after 1830, was not related to demand factors, but to inflation. Data from West Africa and Angola (which supplied slaves) show price volatility during the Napoleonic Wars, but the prices in the late 1820s were comparable to those registered in the 1790s. ${ }^{123}$ Nonetheless, Brazilian literature shows that the idea of a constant increase in real slave prices up to 1850 is widely held, especially between 1820 and 1840, when nominal prices doubled. ${ }^{124}$ According to Bergad, for example, the expansion of the coffee industry in Rio de Janeiro and São Paulo, as well as British pressure to end the slave trade, caused a rapid increase in prices in Minas Gerais during the 1830 s. ${ }^{125}$

However, the data in Figure 6.5 and 6.6 suggest that the devaluation of the Brazilian currency can provide partial explanation for the increase in prices, especially after $1827 .{ }^{126}$ While the dollar was stable after the end of the Napoleonic Wars, the mil-réis underwent a continuous devaluation against the British pound; around 2.9 percent per annum until the beginning of the Second Reign, in the 1840s. ${ }^{127}$ Large emissions of paper money increased devaluation in the 1820 s, especially during the crisis that caused the end of the first Bank of Brazil, between 1827 and $1830 .{ }^{128}$ It is important to note that at the end of the 1820 s, slave prices also fell in the United States, and the devaluation of the mil-réis could have reinforced that trend. Comparing the average prices before and after the monetary crisis (between 1827 and 1831), slave prices in Minas Gerais and Rio Grande do Sul increased by 35 percent, but the continuous growth in nominal prices disappears.

\footnotetext{
${ }^{123}$ Ronald Findlay and Kevin H. O'Rourke, Power and Plenty: Trade, War, and the World Economy in the Second Millennium (Princeton, N.J. ; Woodstock, Oxfordshire England: Princeton University Press, 2007), 371; Joseph C. Miller, "Slave Prices in the Portuguese Southern Atlantic, 1600-1830," in Africans in Bondage: Studies in Slavery and the Slave Trade, by Paul E. Lovejoy (Madison: African Studies Program, University of Wisconsin, 1986).

${ }^{124}$ Versiani and Vergolino, "Posse de Escravos E Estrutura Da Riqueza No Agreste E Sertão de Pernambuco," 372; Kátia M. de Queirós Mattoso, Herbert S. Klein, and Stanley L. Engerman, "Research Note: Trends and Patterns in the Prices of Manumitted Slaves: Bahia, 1819-1888," Slavery \& Abolition 7, no. 1 (May 1, 1986 ): 61. ${ }^{125}$ Laird W. Bergad, Slavery and the Demographic and Economic History of Minas Gerais, Brazil, 1720-1888 (New York: Cambridge University Press, 1999), 167.

126 This increase does not appear on the prices of Maranhão because the data after 1820 is not for "prime field hands," which were lower on average.

${ }^{127}$ Heitor Pinto de Moura Filho, "Câmbio de longo prazo do mil-réis: uma abordagem empírica referente às taxas contra a libra esterlina e o dólar (1795-1913),” Cadernos de História 11, no. 15 (2010): 20, doi:10.5752/P.2237-8871.2010v11n15p9.

${ }^{128}$ William R. Summerhill, Inglorious Revolution: Political Institutions, Sovereign Debt, and Financial Underdevelopment in Imperial Brazil (New Haven: Yale University Press, 2015), xiii.
} 


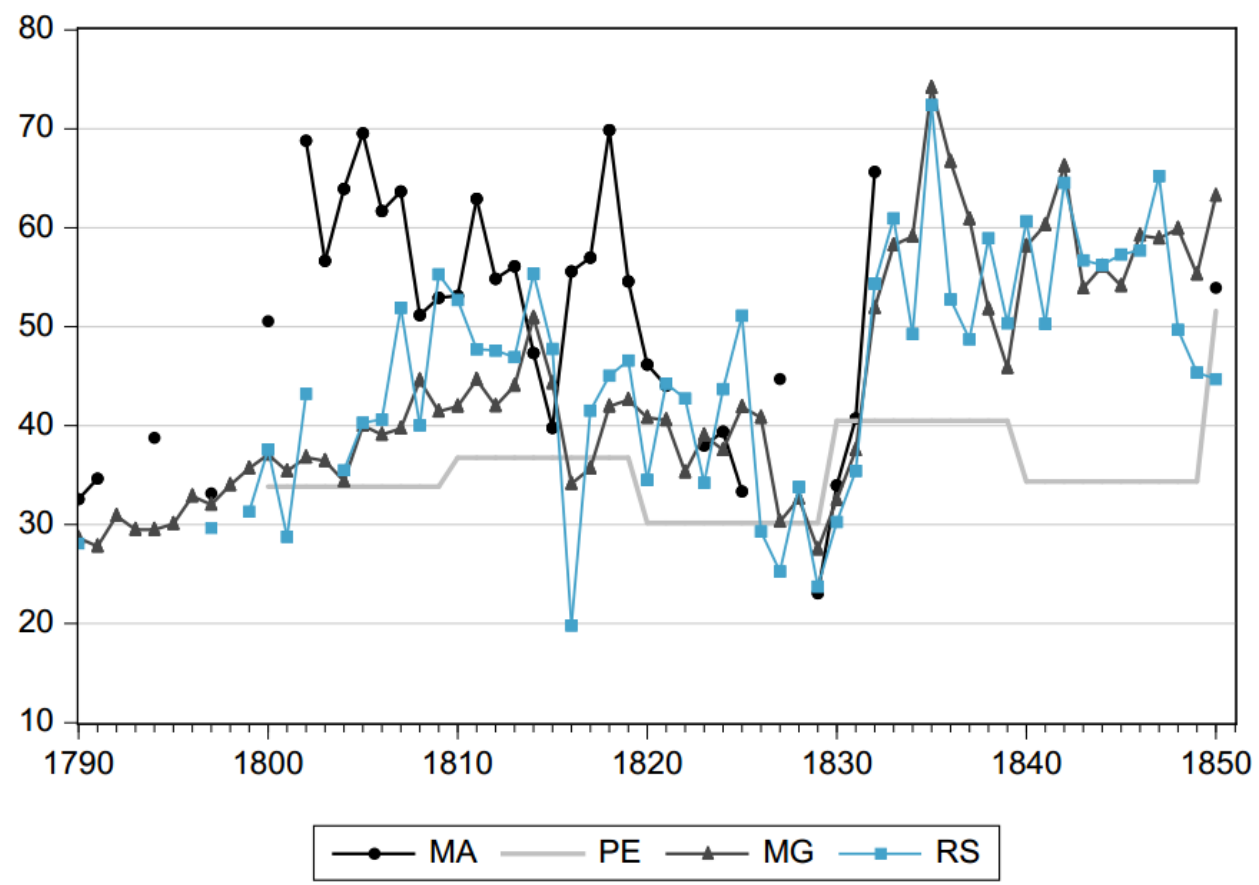

Figure 6.6 - Slave prices in Maranhão, Pernambuco, Minas Gerais, and Rio Grande do Sul (f) Sources: See text.

Even with the exchange rate devaluation, part of the increase in prices after 1830 was invariably a response to restrictions in the slave trade. A citizen of the United States who lived in Brazil in the 1830s, exploring diamond mines, wrote that when the slave trade officially ceased, there were few slaves, "to be had at any price." ${ }^{129}$ This situation led to the emergence of new slave traders that subsequently became very wealthy. While in 1825 , the average price for a slave was 200 mil-réis, right after 1830 the average prices rose to 780 mil-réis (730 milréis if they were "paid for on sight"). Credit terms of between six and twelve months were usual, but an "industrious man" could have credit up to two years, paying the bills with the labor he had acquired during that time. The report also states that prices fell rapidly between 1833 and 1836, reaching a low point (400 mil-réis) in 1837. These price variations, however, are also closely correlated with changes in the exchange rate at the time, which reinforce the idea that part of the increase in slave prices after 1830 was not related to supply shocks from the end of the slave trade.

\subsection{Conclusions}

This chapter provided evidence that, far from being a poor man's crop, cotton plantations made extensive use of slave labor until the 1840s. Information from population

\footnotetext{
129 “The Slave Trade," Anti-Slavery Bugle, June 9, 1848, Vol.3 No.43 edition, 3, Library of Congress, Chronicling America.
} 
maps shows that slaves represented half the population in Maranhão even two decades after cotton exports stopped increasing. This represented a higher share than that observed in any Northeast region in Brazil, and was comparable to those recorded in the U.S. South. One important difference compared to the U.S. South was Brazil's dependence on the slave trade. Negative fertility rates in cotton regions confirm previous findings for Brazil, which were that planters needed the slave trade to be able to keep up production with bonded labor.

In terms of how changes in demand and supply affected the labor market, price information suggests that the cotton boom made slave prices in Maranhão increase more than other regions in Brazil. This finding is important because price data show that slave markets in Brazil had low price dispersion between different provinces during the nineteenth century. Since the Atlantic slave trade set prices until 1850, different routes and labor demand for a booming export staple explain higher prices in Maranhão between 1790 and 1820 . 


\section{Conclusions}

The rise and fall of the cotton economy in Brazil described in this dissertation was a process that lasted over more than a century. Despite being a native plant to Brazil, large scale cotton production began only when the Portuguese government formulated policies during the 1760 s to increase agricultural production in the northeast. The new trade companies created during Pombal's government transported slaves and brought capital to places that had previously been developed, such as Pernambuco, but also to the faraway regions of Maranhão and Pará. Initially, cotton was one among several agricultural products that the Portuguese government tried to promote. The value of cotton in Brazil, however, rapidly increased after spinning machines across the Atlantic began to use longer staples native to South America. Britain's previous suppliers of raw cotton - in the West Indies and in Asia - did not produce a fiber suitable for the new calico and muslin production. Moreover, by turning to foreign suppliers in South America, muslin makers stated that the measure was not intended to undermine planters from the British West Indies; muslins "simply required a cotton which could never be grown there."

Foreign trade in northeastern Brazil, therefore, initially expanded during the last two decades of the eighteenth-century mainly due to its natural endowments. Pernambuco and Maranhão possessed a valuable commodity, with no close substitutes, for a key industry in Britain. It is remarkable that Brazilian cotton represented 40 percent of raw cotton imports in Liverpool in the 1790s. Meanwhile, cotton surpassed for some years sugar as the most important commodity in Pernambuco. The commercial and political proximity between Portugal and Britain helped Brazilian cotton reach Lancashire markets, but as the period after 1808 showed, the Portuguese intermediation was not a necessary condition for success. Unlike previous interpretations of Brazilian economic history, the growth of Brazil's cotton trade - discussed in Chapter 2 - was not related to the United States' war for independence and the revolutions in the Caribbean.

The northeastern provinces enjoyed a short period without a powerful international competitor due to war and the diplomatic conflicts between the United States and Britain, which lasted until 1815. For more than three decades, therefore, the surge in exports became a great opportunity for economic growth. The increase in export prices was especially important for Maranhão, a province considered at the time as still lying in an "infant state," at least when

\footnotetext{
${ }^{1}$ Edwards, The Growth of the British Cotton Trade, 1780-1815, 81.
} 
compared to Pernambuco and Bahia. ${ }^{2}$ Maranhão exports and imports per capita were higher than the richer provinces of Pernambuco and Bahia during the cotton boom years. Contrary to the view that the British trade generated only trade deficits across Brazil after 1810, Maranhão had a continuous trade surplus with Britain until 1837 - even with the stagnation of exports after 1819.

Decades of favorable economic environment for cotton planters raise two crucial questions to which this dissertation offers new evidence: 1) why did the growth of cotton exports "wither away" after 1819?2) did the increase in cotton trade have any persistent effect on the northeastern economies? These questions have remained largely unanswered because no previous study had attempted to connect the rise of the cotton trade in Brazil during the last decades of the eighteenth century with its subsequent stagnation. As mentioned in the previous chapters, most studies focused either on the period after 1850 , or the colonial period. ${ }^{3}$ However, it is the years between 1808 and 1850 that provide the essential elements to understand the lack of Brazilian competitiveness in international markets.

The foremost reason for placing 1808 the point of departure is that the arrival of the royal family resulted in two major changes in cotton production. On the positive side, the end of the Portuguese monopoly on trade allowed the commerce of the northeastern provinces to expand. Trade expansion was countered, however, by new taxes to support the augmented government in Rio de Janeiro and to rebuild parts of Portugal ravaged by war. The new taxes initially did not have a clear impact on cotton exports because high prices - due to wars in Europe and the United States - brought an increasing number of foreign vessels to Brazilian ports. But as cotton prices declined, the profitability of planters was reduced substantially because taxes with a fixed nominal value increased the effective tax rate. Between 1808 and 1850, export taxes in Maranhão represented on average 19 percent of cotton prices - higher than transport costs to provincial ports and freight rates to Liverpool.

After the United States' large increase in British cotton markets during the 1820s, Brazilian producers could not affect international prices and, therefore, any taxation on exports would reduce domestic prices. But, since Brazil produced more than one kind of cotton - which attended distinct markets - planters could withstand different levels of taxation. Price

\footnotetext{
${ }^{2}$ Koster, Travels in Brazil, 171.

${ }^{3}$ For studies that analyze the cotton trade during the colonial period see María Regina Ciparrone Mello, $A$ industrialização do algodão em São Paulo (Editora Perspectiva, 1983); José Jobson de Andrade Arruda, O Brasil no comércio colonial (Editora Atica, 1980).
} 
information from Britain and Brazil show that cotton from Pernambuco was of a higher quality and competed with staples such as the U.S. Sea Island and the Egyptian. The market for longstaple cotton was different from shorter-staples because the use of its fiber was restricted to high quality products, which had lower production and higher profit rates. Moreover, longstaple cotton was characterized by an inelastic supply because it could be grown only in some regions. Like Pernambuco, exports of Sea Island and Egyptian cotton to Britain remained stable between the 1820 s and 1850 - each region exported on average less than 10 million lbs. annually. ${ }^{4}$ The distinct characteristics of markets for long-staple cotton, especially its higher price, allowed plantations in Pernambuco to be more profitable than in Maranhão.

Maranhão exported mainly short staple cotton, which faced heavy competition from the new cotton areas in the United States. The "upland" cotton - which constituted more than one variety - was a close substitute for Maranhão's staple, was easier to cultivate than Sea Island, and enjoyed growing demand in Europe. ${ }^{5}$ With lower profits, planters in Maranhão were on average much more sensible to price variations than those from Pernambuco. Moreover, unlike Pernambuco, Maranhão's economy was more dependent on cotton exports: rice production was not as profitable as sugar was in other northeastern provinces and thus did not constitute a viable economic alternative to cotton production. Therefore, when cotton prices started to decline after 1819, and export taxes eroded a large part of planter's profits, planters were confronted with two choices: increase productivity or find a way to reduce prices of inputs to cotton production.

Chapters 4, 5, and 6 of this dissertation provide new data in order to illustrate the response of Brazilian planters to the lower profits after 1819. The evidence provided in these chapters seeks to test hypotheses presented in the traditional literature for the stagnation of cotton exports, which focused mainly on market variables such as transport costs and insufficient labor supply. For previous studies, limited quantitative evidence for the early nineteenth century seriously restricted the ability of scholars to test if these factors contributed to cotton stagnation in Brazil. When exports stopped growing during the 1820s, railroads and other major improvements in transportation were still not economically viable. Moreover, flatboats still carried most of the freight to southern ports in the United States - even with the rapid expansion of steamboats. Cotton areas in Brazil were normally distant from the coast and had no proper roads or riverways, but this does not imply that transport costs were the most important factor for low profitability in cotton plantations. At the time exports stopped growing,

\footnotetext{
${ }^{4}$ Mann, The Cotton Trade of Great Britain, 99; Donnell, Chronological and Statistical History of Cotton.

${ }^{5}$ Edwards, The Growth of the British Cotton Trade, 1780-1815, 92.
} 
high transport costs were a widespread problem across plantations in the Americas. In addition to not being restricted to Brazil, Chapter 3 and 4 showed that transportation - both inland and maritime - was not among the most important costs to cotton production.

The largest cost of producing a pound of cotton in northeastern Brazil was related to the labor force. Slaves were a considerable investment to planters and any factor that increased their prices had a large impact on production. This is the reason why most studies that focused on the period after 1850 argued that competition for labor and capital by coffee plantations in Southern Brazil represented an insurmountable challenge for the cotton economy. Indeed, without the transatlantic slave trade to supply new field laborers, slave prices increased after 1850 and prompted the reallocation of captives from the less productive areas in the northeast to the expanding coffee regions. However, the stagnation of cotton exports in Brazil began several years before the end of the slave trade. Chapter 6 showed that cotton plantations made extensive use of slave labor until the 1840s and, in Maranhão, the average slave-holding unit was similar to cotton plantations in the United States. Slave prices in Maranhão during the cotton boom increased more than other regions in Brazil during the first two decades of the nineteenth century, suggesting a higher profitability of using slaves in cotton plantations.

Chapter 6 also showed that slave prices were lower in Brazil than the United States until the 1850s. Therefore, the important difference for Brazilian planters was not in prices, but in productivity. Low agricultural productivity in underdeveloped regions is often seen as the result of low human capital and inefficient credit markets. Farmers can be ignorant about how to increase their yields or lack resources to adopt technologies when they are familiar with better practices. Evidence, once again, shows that this was not the case for planters in Brazil, who were familiar with ginning technology and started to use seeds with higher yields from the United States in the 1830s. There is no information about the dissemination of technological adoption, but the appearance of saw-ginned cotton from Maranhão in British newspapers during the 1830s suggests that it was not slight. Data presented in Chapter 3, however, showed that it was not until the 1860s that foreign commerce in Maranhão surpassed trade levels from the 1810s. Cotton seed from the United States represented higher yields but also lower prices, which were not profitable in Maranhão with continuous low prices during the 1840s.

Slave prices and transport costs cannot be the main reason for the cotton stagnation in Brazil because planters responded to market incentives. Plans to implement steam navigation and the adoption of new seeds appeared during the 1830s and 1840s, when prices in British 
markets decreased. What planters could not change in the short-run was a fiscal policy that taxed exports with a fixed amount, regardless of the price level. Chapter 5, which estimated the elasticity of export demand for Brazilian cotton, showed that the level of taxation set by the central government was higher than the optimal amount, hurting domestic production. Even with the public outcry about high taxes, reforms were delayed up until 1831, when the decision by the central government to allow the circulation of undervalued copper coins and paper notes in the northeast created a new problem. Since part of the export taxes had to be paid in silver, high premiums for silver coins with the invasion of undervalued money in northern provinces during the 1830s increased the effective export tax rate once again. Tax payments in silver raised trade costs substantially and reduced profits for cotton planters until 1846, when a new monetary reform finally solved the problem.

Fiscal and political centralization also provide an answer to Celso Furtado's argument regarding the "false euphoria" of the cotton economy after the colonial period. Brazil became independent at a time when two important changes in cotton markets lowered prices: the normalization of commerce after the wars in Europe and the United States, and Britain's return to the gold standard. ${ }^{6}$ Apart from falling international prices, there was no significant change in fiscal policy and other input prices in the years after independence that is correlated with the stagnation in cotton exports. The effects of colonial rule, however, were not absent. There is limited information on the profitability of cotton plantations before 1808 , but it is fair to assume that Portuguese control of Brazilian ports, acting as a monopsonist, would limit profits for local planters. Therefore, profits were also not high before the new taxes appeared in 1808 .

In addition to increased production costs, the fiscal policies implemented by the Brazilian central government also affected the supply of public goods in Maranhão and Pernambuco. Fiscal centralization, in which revenues collected from the main export taxes were in large part transferred to the central government, left provinces without the resources to undertake important investments in transportation that could lower production costs for cotton planters. Moreover, provinces with limited capacity to organize their own budgets suffered from the slow response from the central government even for small infrastructure projects - as clearly shown by the case of the new bridge to increase access to the custom-house in São Luís described in Chapter 4.

\footnotetext{
${ }^{6}$ Lower prices from an increase in supply - and not only an effect from the exchange rate - is clear in Figure 3.7, which shows that prices also declined after 1819 at Brazilian ports in local currency.
} 
This dissertation, therefore, provides evidence that high production costs - due to low productivity - were mostly a consequence of political factors, especially fiscal policies that reduced domestic cotton prices and hurt producers. Cotton planters in the northeast did not have the necessary political power to pressure the central government to reduce taxation, which made them vulnerable to exogenous changes in prices. The lack of fiscal capacity, along with Portugal's monopoly on trade before 1808, created an economic environment in which Brazil played a key role in the early history of the Industrial Revolution, but the rise of cotton exports did not translate into sustained economic development for the northeastern provinces. In a period where taxation was not related to political representation, the cotton boom years were unfortunately a "nonmarket golden age in which rents and hierarchy ruled."”

\footnotetext{
${ }^{7}$ Deirdre N. McCloskey, "How the West (and the Rest) Got Rich," Wall Street Journal, May 20, 2016, sec. Life, http://www.wsj.com/articles/why-the-west-and-the-rest-got-rich-1463754427.
} 


\section{References}

\section{Primary Sources:}

“Ainda a Lei Do Orçamento Deste Anno." O Observador. October 6, 1847, 11-12 edition. Memória Digital, Biblioteca Nacional.

Anais Do Senado Do Império Do Brasil. 1823-1888. Brasília: Senado Federal - Subsecretaria de Anais, 1978.

Annaes Do Parlamento Brasileiro, 1826.

Annaes do Parlamento Brazileiro. Camara Dos Srs. Deputados, 1830. Vol. 2. Rio de Janeiro: Typographia de H. J. Pinto, 1878.

“Artigo Communicado.” Echo Do Norte. July 7, 1834, N.2 edition. Memória Digital, Biblioteca Nacional.

“Artigo D’officio.” Diario de Pernambuco. May 27, 1831, 112 edition. Memória Digital, Biblioteca Nacional.

“Artigo d'Officios." O Publicador Official. September 28, 1833, 196 edition. Memória Digital, Biblioteca Nacional.

Assembleia Legislativa Provincial. "Relatorio Do Presidente Da Provincia Do Maranhão, O Doutor Eduardo Olimpio Machado, Na Abertura Da Assembléa Legislativa Provincial No Dia 3 de Maio de 1854, Acompanhado Do Orçamento Da Receita E Despeza Para O Anno de 1855." Maranhão, 1854. Center for Research Libraries, Global Resources Network. http://www-apps.crl.edu/brazil/provincial/maranhão.

"Bahia, Comércio." Gazeta Do Rio de Janeiro. April 19, 1817, 32 edition. Memória Digital, Biblioteca Nacional.

Brasil. Ministério da Fazenda. "Ministro José Ignacio Borges. Relatório... Do Anno de 1830 Apresentado Na Sessão de 1831." Rio de Janeiro, 1831. Center for Research Libraries, Global Resources Network. http://brazil.crl.edu/bsd/bsd/u1510/000001.html.

"Brazil Finanças." Correio Braziliense. 1810, 5 edition, sec. Miscellanea. Memória Digital, Biblioteca Nacional.

"Brazil. Finanças." Correio Braziliense. 1810, 5 edition, sec. Miscellanea.

"Carta Ao Editor." Diario de Pernambuco. January 25, 1830, 298 edition. Memória Digital, Biblioteca Nacional.

“Carta Régia." Gazeta Do Rio de Janeiro, January 15, 1812, 5 edition. Memória Digital, Biblioteca Nacional.

Coleção Das Leis Do Brazil (1821 - 1825). Rio de Janeiro: Typographia Nacional, 1889.

Coleção de Decretos, Cartas Imperiais E Alvar[as Do Império Do Brazil. Coleção Das Leis Do Império (1808 - 1889). Rio de Janeiro: Typographia Nacional, 1885.

Collecção Das Leis Do Brazil de 1808. Rio de Janeiro: Imprensa Nacional, 1891.

Collecção Das Leis Do Imperio Do Brazil. Coleção Das Leis Do Império (1808 - 1889). Rio de Janeiro: Typographia Nacional, 1878.

“Consulado Britanico, Representação.” O Publicador Official. October 22, 1834, 307 edition. Memória Digital, Biblioteca Nacional.

"Consuls Alexander Cunningham, William Pennell, Robert Hesketh, John Lempriere, Cox, and John Parkinson, Etc. (Brazil), FO 63/240,” 1821. The National Archives, Kew. 
"Consuls Wilson, John Moon, James F. Tauton, Henry Cowper. FO 13/104," 1833. The National Archives, Kew.

"Correspondência." A Aurora Fluminense. August 26, 1829, 231 edition, sec. Variedades. Memória Digital, Biblioteca Nacional.

“Correspondencia, Mercator." Jornal Do Commercio. June 5, 1829, 490 edition, sec. Correspondencia. Memória Digital, Biblioteca Nacional.

"Cotton Business." Manchester Mercury. December 28, 1790, 2064 edition. The British Newspaper Archive.

“Discurso [...] Recitou Sr. Candido Joze de Araujo Vianna, Presidente D’esta Provincia." $O$ Farol Maranhense. December 1, 1829, 146 edition. Memória Digital, Biblioteca Nacional.

"Discurso Ministro Da Fazenda, Miguel Calmon Du Pin E Almeida." Diario de Pernambuco. April 25, 1829, 89 edition. Memória Digital, Biblioteca Nacional.

"Discurso Que Recitou O Exm. Snr. Manoel Felisardo de Sousa E Mello, Presidente Desta Provincia, Na Occazião Da Abertura Da Assemblea Legislativa Provincial.” Maranhão, May 3, 1839. Center for Research Libraries, Global Resources Network. http://brazil.crl.edu/bsd/bsd/338/.

"Discurso Recitado Pelo Exm. Snr. Doutor João Antonio de Miranda, Prezidente Da Provincia Do Maranhão, Na Abertura Da Assemblea Legislativa Provincial.” Maranhão, July 3, 1841. Center for Research Libraries, Global Resources Network. http://brazil.crl.edu/bsd/bsd/340/.

"Falla Com Que O Exm. Sr. Dr. Cincinnato Pinto Da Silva, Presidente Da Provincia, Installou a 2.a Sessão Ordinaria Da 23.a Legislatura Provincial Do Maranhão Em 19 de Fevereiro de 1881. Maranhão, 1881.” Maranhão, February 19, 1881. Center for Research Libraries, Global Resources Network. http://brazil.crl.edu/bsd/bsd/385/index.html.

"Falla Dirigida Pelo Exm. Presidente Da Provincia Do Maranhão, Honorio Pereira de Azeredo Coutinho, Á Assembléa Legislativa Provincial." Maranhão, 1850. Center for Research Libraries, Global Resources Network. http://brazil.crl.edu/bsd/bsd/348/.

"Falla Que Recitou O Exm. Presidente E Commandante Das Armas Da Provincia Do Maranhão, O Coronel Luiz Alves de Lima, N'abertura Da Assemblea Legislativa Provincial." Maranhão, 1840. Center for Research Libraries, Global Resources Network. http://brazil.crl.edu/bsd/bsd/339/.

"Falla Que Recitou O Presidente Da Provincia Do Maranhão, Antonio Joaquim Alvares Do Amaral, Na Abertura Da Assembléa Da Mesma Provincia Em 28 de Julho de 1848." Maranhão, 1848. Center for Research Libraries, Global Resources Network. http://brazil.crl.edu/bsd/bsd/346/.

"FO 13/12 - Lord A. Marcus C. Hill, Consuls John Parkinson and Robert Hesketh.," 1825. The National Archives, Kew.

"FO 13/30 - Arthur Aston, Consuls John Parkinson and Robert Hesketh.," 1826. The National Archives, Kew.

"FO 13/40 - Arthur Aston, Consuls Henry Chamberlain, John Parkinson, Robert Hesketh.," 1827. The National Archives, Kew. 
"FO 13/77 - Consuls Baldwin Sealy, Robert Hesketh, William Hesketh, John Hesketh, Foreign Various, and Consular Domestic.," 1830. The National Archives, Kew.

"FO 63/149 - Sir F. B. Hill, Consuls Robert Hesketh, A. Cunningham, Frederick Lindeman, and Various (Brazil).," 1813 1812. The National Archives, Kew.

"FO 63/215 - Consuls Alexander Cunningham, William Pennell, John Lempriere, Robert Hesketh, John Jeffery, John Crispin, William Harding Read, and Henry Veitch, Etc. (Portugal and Brazil).," 1818. The National Archives, Kew.

"FO 63/240 - Consuls Alexander Cunningham, William Pennell, Robert Hesketh, John Lempriere, Cox, and John Parkinson, Etc. (Brazil).," 1821. The National Archives, Kew.

“FO 63/240 Consuls' Office.” Maranham, May 20, 1821. FO 63/240. British National Archives.

"FO 63/249 - Consuls Alexander Cunningham, Robert Hesketh, and William Pennell, Etc. (Brazil).," 1822. The National Archives, Kew.

"FROM BRAZIL.; The Times in Brazil--The Activity of Pernambuco." The New York Times, December 19, 1863.

"From H. Chamberlain (Brazil), FO 63/246," September 1822. The National Archives, Kew.

"Further Extract from Memorials of the British Consul and Factory at Lisbon." The Caledonian Mercury. December 13, 1766, 6927 edition. The British Newspaper Archive.

House of Commons. "Report Together with Minutes of Evidence, and Accounts, from the

Select Committee on the High Price of Gold Bullion," June 8, 1810. House of Commons Parliamentary Papers Online.

"House of Lords.." The Times. March 1, 1787, 688 edition. The Times Digital Archive 17852006 (Gale).

“Interior: Noticias Do Pará.” Jornal Do Commercio. January 7, 1836, 4 edition.

"Ledgers of Imports and Exports." Volume(s), 1780 1697. CUST 3. The National Archives, Kew.

“Ledgers of Imports Under Countries.” London, 1899 1809. CUST 4. The National Archives, Kew.

“L'Esperance Console de Tous Les Maux.” Conciliador Do Maranhão. June 19, 1822, 98 edition.

"Lista Dos Negociantes." Conciliador Do Maranhão. February 20, 1822, 64 edition.

"Maranhão." Echo Do Norte. October 14, 1834, 29 edition. Memória Digital, Biblioteca Nacional.

“Maranhão: Artigos D’Officio.” O Publicador Official. May 24, 1837, 553 edition. Memória Digital, Biblioteca Nacional.

"Maranhão (Provincia) Presidente (Franco de SA)." Maranhão, May 3, 1847. Center for Research Libraries, Global Resources Network. http://brazil.crl.edu/bsd/bsd/345/.

"Memoria Do Lavrador José Joaquim Vieira Belford." Conciliador Do Maranhão. March 2, 1822, 67 edition.

"Memoria Sobre a Decadencia Da Lavoura E Outros Ramos de Prosperidade Publica No Destricto de Aldeas Altas Que Percizão Ser Providenciados." Conciliador Do Maranhão. March 2, 1822, 67 edition. 
"Mr. Eden Has Been More Negligent, and Less Informed, in the Affair of the Commercial Treaty,." The Times. December 7, 1786, 565 edition. The Times Digital Archive 17852006 (Gale).

“Notícias Maranhão.” Publicador Maranhense. July 13, 1851, 1133 edition. Memória Digital, Biblioteca Nacional.

“O Algodão.” O Auxiliador Da Industria Nacional, December 1853, 6 edition, sec. Industria Agricola e Rural. Memória Digital, Biblioteca Nacional.

"OFÍCIO Do Governador E Capitão Do Maranhão E Piauí, D. Diogo de Sousa Para O Secretário de Estado Da Marinha E Ultramar, D. Rodrigo de Sousa Coutinho.” São Luís do Maranhão, Abril 1799. AHU_CU_009, Cx. 104, D. 8313. Arquivo Histórico Ultramarino.

“Os Direitos de Exportação.” Diario Do Maranhão. July 22, 1874, 290 edition. Memória Digital, Biblioteca Nacional.

"Pará." Echo Do Norte. October 18, 1835, Vol 2, N.6 edition. Memória Digital, Biblioteca Nacional.

“Porque Soffre a Lavoura No Brazil.” Diario Do Maranhão. January 28, 1875, 445 edition. Memória Digital, Biblioteca Nacional.

"Portugal.." The Times. September 30, 1788, 1132 edition. The Times Digital Archive 17852006 (Gale).

“Relatorio 1858.” Maranhão, 1858. Center for Research Libraries, Global Resources Network. http://brazil.crl.edu/bsd/bsd/u328/.

“Relatório Da Província Do Maranhão 1852.” Maranhão, 1852. Center for Research Libraries, Global Resources Network. http://brazil.crl.edu/bsd/bsd/u322/.

"Relatorio Do Presidente Da Provincia Do Maranhão, O Doutor Eduardo Olimpio Machado, Na Abertura Da Assembléa Legislativa Provincial." Maranhão, 1853. Center for Research Libraries, Global Resources Network. http://brazil.crl.edu/bsd/bsd/351/.

"Relatorio Do Presidente Da Provincia Do Maranhão, O Doutor Eduardo Olimpio Machado, Na Abertura Da Assembléa Legislativa Provincial No Dia 3 de Maio de 1854, Acompanhado Do Orçamento Da Receita E Despeza Para O Anno de 1855." Maranhão, 1854. Center for Research Libraries, Global Resources Network. http://brazil.crl.edu/bsd/bsd/352/.

"Relatorio Do Presidente Da Provincia Do Maranhão, O Doutor João Lustosa Da Cunha Paranaguá, Na Abertura Da Assembléa Legislativa Provincial No Dia 3 de Maio de 1859." Maranhão, 1859. Center for Research Libraries, Global Resources Network. http://brazil.crl.edu/bsd/bsd/358/.

“Representação; Os Abaixo Assignados Negociantes, E Proprietarios Desta Cidade." $O$ Publicador Official. March 25, 1835, 351 edition. Memória Digital, Biblioteca Nacional.

"Requerimento a Que Se Referem Reflexões Do Nosso Correspondente." O Constitucional. Jornal Politico E Literário. April 15, 1830, 83 edition.

"Rio de Janeiro." A Aurora Fluminense. August 23, 1830, 378 edition, sec. Interior. Memória Digital, Biblioteca Nacional. 
“Sessão Ordinaria Em 2 de Junho de 1832.” Diario Da Camara Dos Senadores, 1832, 25 edition. Memória Digital, Biblioteca Nacional.

“Sobre a Lei Monetaria de 3 de Outubro Proximo Passado." Echo Do Norte. July 14, 1834, 4 edition, sec. Maranhão. Memória Digital, Biblioteca Nacional.

"Sobre O Discurso Do Eisel. Sr. Prezidente Thomaz Xavier Garsia de Almeida." Abelha Pernambucana. December 11, 1829, 67 edition. Memória Digital, Biblioteca Nacional.

"Sr. Redator (Cartas)." O Publicador Official. May 10, 1834, 260 edition. Memória Digital, Biblioteca Nacional.

"State of Public Affaire, Commons Sitting." London, June 20, 1805. Hansard. http://hansard.millbanksystems.com/.

"States of Navigation, Commerce and Revenue." Volume(s), 1808 1772. CUST 17. The National Archives, Kew.

"The Following Is an Authentic ABSTRACT of the TREATY of NAVIGATION and COMMERCE, Signed at Paris on the 26th Ult..” The Times. October 5, 1786, 547 edition. The Times Digital Archive 1785-2006 (Gale).

“The Island of Martinique." The Times. May 2, 1794, 2978 edition. The Times Digital Archive 1785-2006 (Gale).

"The Memorial of Francis Ibbetson." The Caledonian Mercury. September 23, 1767, 7048 edition. The British Newspaper Archive.

"The National Archive of the UK BT 6/63," 1791 1770. The National Archives, Kew.

"The National Archive of the UK BT 6/140," 1792 1787. The National Archives, Kew.

"The National Archive of the UK CO 37/40/21," February 5, 1787. The National Archives, Kew.

“The National Archive of the UK SP 89/49/54," June 10, 1753. The National Archives, Kew. "The National Archive of the UK SP 89/67/7," January 14, 1769. The National Archives, Kew. “The National Archive of the UK SP 89/77/24," July 4, 1774. The National Archives, Kew. "The National Archive of the UK T 64/275/142," February 1779. The National Archives, Kew. "The National Archive of the UK T 64/275/143," February 1779. The National Archives, Kew. "The Records of Cardwell, Birley and Hornby." Manchester, 1792 1768. Ms. 1199. The John Rylands Library.

“The Slave Trade." Anti-Slavery Bugle. June 9, 1848, Vol.3 No.43 edition. Library of Congress, Chronicling America.

"To Be Sold, by Action.” Manchester Mercury. March 13, 1787, 1866 edition.

"Tráfico de Escravos." Farol Marenhense. January 5, 1830.

"Universal Register.." The Times. October 20, 1786, 560 edition. The Times Digital Archive 1785-2006 (Gale). 


\section{Secondary Sources:}

Abreu, Marcelo de Paiva, and Luiz A. Corrêa do Lago. "Property Rights and the Fiscal and Financial System in Brazil." In Transferring Wealth and Power from the Old to the New World: Monetary and Fiscal Institutions in the 17th Through the 19th Centuries, edited by Michael D. Bordo and Roberto Cortés-Conde, 327-77. Cambridge University Press, 2006.

Acemoglu, Daron, Maria Angélica Bautista, Pablo Querubín, and James A. Robinson. "Economic and Political Inequality in Development: The Case of Cundinamarca, Colombia." In Institutions and Economic Performance, edited by Elhanan Helpman, 181-245. Cambridge: Harvard University Press, 2007.

Acemoglu, Daron, Simon Johnson, and James A. Robinson. "The Colonial Origins of Comparative Development: An Empirical Investigation." American Economic Review 91, no. 5 (December 2001): 1369-1401. doi:10.1257/aer.91.5.1369.

Albuquerque, Rui H. P. L. de. Capital comercial, indústria têxtil e produção agrícola: as relações de produção na cotonicultura paulista, 1920-1950. São Paulo, Brasília: Editora HUCITEC, 1982.

Alden, Dauril. "Late Colonial Brazil, 1750-1808." In Colonial Brazil, edited by Leslie Bethell, 284-343. Cambridge ; New York: Cambridge University Press, 1987.

. "The Population of Brazil in the Late Eighteenth Century: A Preliminary Study." The Hispanic American Historical Review 43, no. 2 (1963): 173-205. doi:10.2307/2510491.

Alencastro, Luiz Felipe. O Trato dos Viventes. São Paulo, Brazil: Companhia das Letras, 2000.

Allen, Robert C. The British Industrial Revolution in Global Perspective. 1 edition. Cambridge ; New York: Cambridge University Press, 2009.

Andrade, Manuel Correia de Oliveira. Nordeste, espaço e tempo. Caminhos Brasileiros. Editōra Vozes, 1970.

Armytage, Frances. The Free Port System in the British West Indies: A Study in Commercial Policy, 1766-1822. Longmans, Green and Co., 1953.

Arruda, José Jobson Andrade de. "O Algodão Brasileiro Na Época Da Revolução Industrial." América Latina En La Historia Económica 23, no. 2 (May 2, 2016): 167-203. doi:10.18232/alhe.v23i2.712.

Arruda, José Jobson de Andrade. O Brasil no comércio colonial. Editora Atica, 1980.

- Uma colônia entre dois impérios: a abertura dos portos brasileiros 1800-1808. Cátedra Jaime Cortesão, 2008.

Ashton, T. S. The Industrial Revolution 1760-1830. Oxford Paperbacks University Series, v. 38. Oxford: Oxford University Press, 1968.

Bai, Jushan, and Pierre Perron. "Computation and Analysis of Multiple Structural Change Models." Journal of Applied Econometrics 18, no. 1 (January 1, 2003): 1-22. doi:10.1002/jae.659.

- "Estimating and Testing Linear Models with Multiple Structural Changes." Econometrica 66, no. 1 (1998): 47-78. doi:10.2307/2998540.

Baines, Edward. History of the Cotton Manufacture in Great Britain. R. Fisher and P. Jackson, 1835.

. History of the Cotton Manufacture in Great Britain. R. Fisher and P. Jackson, 1835. 
Barbosa, Luiz Cordelio. "Cotton in 19th Century Brazil: Dependency and Development." University of Washington, 1989.

Barman, Roderick. Brazil: The Forging of a Nation, 1798-1852. Stanford University Press, 1994.

Bastos, Manoel José d'Oliveira. "Roteiro Das Capitanias Do Pará E Maranhão, Piauhy, Pernambuco E Bahia, Pelos Seus Caminhos E Rios Centraes - 1819.” Revista Trimestral Do Instituto Histórico E Geográfico Brasileiro. 1846, Tomo VII-Segunda Edição edition.

Bates, Robert H., John H. Coatsworth, and Jeffrey G. Williamson. "Lost Decades: Postindependence Performance in Latin America and Africa." The Journal of Economic History 67, no. 04 (2007): 917-43. doi:10.1017/S0022050707000447.

Battalio, Raymond C., and John Kagel. "The Structure of Antebellum Southern Agriculture: South Carolina, a Case Study." Agricultural History 44, no. 1 (1970): 25-37.

Beckert, Sven. Empire of Cotton: A Global History. First Edition edition. New York: Knopf, 2014.

Benedict, C. R., R. J. Kohel, and H. L. Lewis. "Cotton Fiber Quality.” In Cotton: Origin, History, Technology, and Production, edited by C. Wayne Smith and J. Tom Cothren, 1 edition., 269-87. New York: Wiley, 1999.

Bergad, Laird. The Comparative Histories of Slavery in Brazil, Cuba, and the United States. Cambridge University Press, 2007.

Bergad, Laird W. Slavery and the Demographic and Economic History of Minas Gerais, Brazil, 1720-1888. New York: Cambridge University Press, 1999.

Bergad, Laird W., Fe Iglesias García, and María del Carmen Barcia. The Cuban Slave Market, 1790-1880. Cambridge England; New York: Cambridge University Press, 1995.

Bertola, Luis, and Jose Antonio Ocampo. The Economic Development of Latin America since Independence. Oxford: Oxford University Press, 2012.

Besley, Timothy, and Torsten Persson. Pillars of Prosperity: The Political Economics of Development Clusters. Princeton University Press, 2011.

Bethell, Leslie. The Abolition of the Brazilian Slave Trade: Britain, Brazil and the Slave Trade Question. Cambridge: Cambridge University Press, 1970.

Bettencourt, José de Sá. Memoria sobre a plantação dos algodões, : e sua exportação; sobre a decadencia de lavoura de mandiocas, no termo da villa de Camamú, comarca dos Ilhéos, governo da Bahia, appresentada, e offerecida a sua alteza real o Principe do Brazil nosso senhor, [Lisbon] : Na officina de Simão Thaddeo Ferreira., 1798.

Bieber, Judy. "The Brazilian Rhône': Economic Development of the Doce River Basin in Nineteenth-Century Brazil, 1819-49'.” Journal of Latin American Studies 48, no. 1 (February 2016): 89-114. doi:10.1017/S0022216X15000851.

Bogart, Dan, Mauricio Drelichman, Oscar Gelderblom, and Jean-Laurent Rosenthal. "State and Private Institutions." In The Cambridge Economic History of Modern Europe: Volume 1, 1700-1870, edited by Stephen Broadberry and Kevin H. O'Rourke, 71-95. Cambridge: Cambridge University Press, 2010.

Bolingbroke, Henry. A Voyage to the Demerary, Containing a Statistical Account of the Settlements There, and of Those on the Essequebo, the Berbice, and Other Contiguous Rivers of Guyana. London : R. Phillips, 1807. 
Boxer, Charles Ralph. The Portuguese Seaborne Empire, 1415-1825. Hutchinson, 1969.

Branner, John. Cotton in the Empire of Brazil; the Antiquity, Methods and Extent of Its Cultivation, Together with Statistics of Exportation and Home Consumption. U.S. Department of Agriculture, 1885. https://archive.org/details/cottoninempireof08bran.

Britton, Karen Gerhardt. Bale O’ Cotton: The Mechanical Art of Cotton Ginning. Texas A\&M University Press, 1992.

Brooks, C. P. Cotton Manufacturing. 3rd ed. London: Blackburn, 1892.

Bruchey, Stuart Weems. Cotton and the Growth of the American Economy, 1790-1860: Sources Readings. Harcourt, Brace \& World, 1967.

Bruhn, Miriam, and Francisco A. Gallego. "Good, Bad, and Ugly Colonial Activities: Do They Matter for Economic Development?" The Review of Economics and Statistics 94, no. 2 (July 19, 2011): 433-61. doi:10.1162/REST_a_00218.

Buck, Norman Sydney. The Development of the Organisation of Anglo-American Trade, 18001850. Yale University Press, 1925.

Burnard, Trevor. Planters, Merchants, and Slaves: Plantation Societies in British America, 1650-1820. University of Chicago Press, 2015.

Butterworth, James. A Complete History of the Cotton Trade: Including Also, that of the Silk, Calico-Printing, \& Hat Manufactories; with Remarks on Their Progress in Bolton, Bury, Stockport, Blackburn, and Wigan, to Which Is Added, an Account of the Chief Mart of These Goods, the Town of Manchester. Manchester: C.W. Leake, 1823.

Camara, Manuel Arruda da. Memoria Sobre a Cultura Dos Algodoeiros E Sobre O Methodo de O Escolher, E Ensacar. Lisboa: Officina da Casa Litteraria, 1799.

Canabrava, Alice P. O Desenvolvimento Da Cultura Do Algodão Na Província de São Paulo, 1861-1875. São Paulo: EDUSP, 2011.

Carreira, António. A companhia geral do Grao-Para e Maranhao: o comercio monopolista, Portugal-Africa-Brasil na segunda metade do seculo XVIII. Companhia editora nacional, 1988.

Carreira, Liberato de Castro. Historia Financeira E Orçamentaria Do Imperio Do Brazil Desde a Sua Fundação, Precedida de Alguns Apontamentos Acerca Da Sua Independencia. Rio de Janeiro: Imprensa Nacional, 1889.

Carvalho, José Murilo de. A construção da ordem: a elite política imperial; Teatro de sombras : a política imperial. Rio de Janeiro: Civilização Brasileira, 2003.

Cavalcanti, Amaro. O Meio Circulante Nacional: Resenha E Compilação Chronologica de Legislação E de Factos. Vol. 1. 3 vols. Rio de Janeiro: Imprensa Nacional, 1893.

- O Meio Circulante Nacional : Resenha E Compilação Chronologica de Legislação E de Factos. Vol. 2. 3 vols. Rio de Janeiro: Imprensa Nacional, 1893.

Chaplin, Joyce E. "Creating a Cotton South in Georgia and South Carolina, 1760-1815." The Journal of Southern History 57, no. 2 (May 1, 1991): 171-200. doi:10.2307/2210413.

Chapman, S. D. "Quantity Versus Quality in the British Industrial Revolution: The Case of Printed Textiles." Northern History 21, no. 1 (January 1, 1985): 175-92. doi:10.1179/007817285790176156.

Chapman, Stanley D. The Cotton Industry in the Industrial Revolution. London: Macmillan, 1972. 
Chapman, Sydney John. The Lancashire Cotton Industry: A Study in Economic Development. Manchester: University Press, 1904.

Clark, Gregory. A Farewell to Alms: A Brief Economic History of the World. Princeton University Press, 2008.

Coatsworth, John H. "American Trade with European Colonies in the Caribbean and South America, 1790-1812." The William and Mary Quarterly 24, no. 2 (April 1967): 243. doi:10.2307/1920838.

Comin, D., and B. Hobijn. "Cross-Country Technology Adoption: Making the Theories Face the Facts." Journal of Monetary Economics 51, no. 1 (January 1, 2004): 39-83. doi:10.1016/j.jmoneco.2003.07.003.

Conrad, Robert Edgar. The Destruction of Brazilian Slavery, 1850-1888. University of California Press, 1972.

Costa, Leonor Freire, José Luís Cardoso, and Nuno Gonçalo Monteiro. O Tratado de Methuen (1703) - Diplomacia, Guerra, Política e Economia. Edited by Livros Horizonte. Lisboa: Livros Horizonte, 2003.

Crafts, N. F. R. British Economic Growth during the Industrial Revolution. Oxford: Clarendon, 1985.

Crafts, N. F. R., and C. K. Harley. "Output Growth and the British Industrial Revolution: A Restatement of the Crafts-Harley View." The Economic History Review 45, no. 4 (1992): 703-30. doi:10.2307/2597415.

Crafts, Nicholas F. R. "The First Industrial Revolution: A Guided Tour for Growth Economists." The American Economic Review 86, no. 2 (1996): 197-201.

Crafts, Nicholas, and Nikolaus Wolf. "The Location of the UK Cotton Textiles Industry in 1838: A Quantitative Analysis.” The Journal of Economic History 74, no. 4 (December 2014): 1103-39. doi:10.1017/S0022050714000874.

Crouzet, François. L'economie Britannique Et Le Blocus Continental, 1806-1813. Presses Universitaires de France, 1958.

Da Silva Mota, Antonia. "A Dinâmica colonial portuguesa e as redes de poder local na Capitania do Maranhão.” Universidade Federal de Pernambuco, 2007.

Daniels, G. W. "American Cotton Trade with Liverpool Under the Embargo and NonIntercourse Acts." The American Historical Review 21, no. 2 (January 1, 1916): 27687. doi:10.2307/1835050.

Dattel, Gene. Cotton and Race in the Making of America: The Human Costs of Economic Power. 1 edition. Chicago: Ivan R. Dee, 2009.

Davis, David Brion. The Problem of Slavery in the Age of Emancipation. First Edition edition. New York: Knopf, 2014.

Davis, Lewis S. "Scale Effects in Growth: A Role for Institutions." Journal of Economic Behavior \& Organization 66, no. 2 (May 2008): 403-19. doi:10.1016/j.jebo.2006.05.007.

Davis, Ralph. The Industrial Revolution and British Overseas Trade. Leicester University Press, 1979.

De Vries, Jan. "The Industrial Revolution and the Industrious Revolution." The Journal of Economic History 54, no. 2 (1994): 249-70. 
Dean, Warren. Rio Claro: A Brazilian Plantation System, 1820-1920. Stanford University Press, 1976.

Deane, Phyllis, and W. A. Cole. British Economic Growth: 1688-1959. At the University Press, 1969.

Deaton, Angus, and John Muellbauer. "An Almost Ideal Demand System." The American Economic Review 70, no. 3 (1980): 312-26.

Dell, Melissa. "The Persistent Effects of Peru's Mining Mita." Econometrica 78, no. 6 (November 1, 2010): 1863-1903. doi:10.3982/ECTA8121.

Denslow, David. “As Origens Da Desigualdade Regional Do Brasil.” In Formação Econômica Do Brasil: A Experiência Da Industrialização, edited by Flávio Rabelo Versiani and José Roberto Mendonça de Barros, 41-61. São Paulo: Saraiva, 1978.

- Sugar Production in Northeastern Brazil and Cuba, 1858-1908. New York \& London: Garland Publishing, 1987.

Dias, Manuel Nunes. A Companhia Geral do Grão Pará e Maranhão (1755-1778). Universidade de São Paulo, Faculdade de Filosofia, Letras e Ciências Humanas, 1971.

Dincecco, Mark, and Gabriel Katz. "State Capacity and Long-Run Economic Performance." The Economic Journal 126, no. 590 (February 1, 2016): 189-218. doi:10.1111/ecoj.12161.

Disney, A. R. A History of Portugal and the Portuguese Empire: From Beginnings to 1807. Vol. 2. Cambridge University Press, 2009.

Donnell, E. J. Chronological and Statistical History of Cotton. New York: J. Stutton \& co., printers, 1872. http://catalog.hathitrust.org/Record/000957820.

Dubois, Laurent. A Colony of Citizens: Revolution \& Slave Emancipation in the French Caribbean, 1787-1804. 1 edition. Chapel Hill, N.C: The University of North Carolina Press, 2004.

Duffy, Michael. "The French Revolution and British Atitudes to the West Indian Colonies." In A Turbulent Time: The French Revolution and the Greater Caribbean, by David Barry Gaspar and David Patrick Geggus, 78-101. Indiana University Press, 1997.

Duguid, Paul. "The Making of Methuen: The Commercial Treaty in the English Imagination." Revista Da Faculdade de Letras História, III, 4 (2003): 09-36.

Dunn, Richard S. A Tale of Two Plantations: Slave Life and Labor in Jamaica and Virginia. Harvard University Press, 2014.

Edwards, Bryan. The History, Civil and Commercial, of the British West Indies. 5th ed. Vol. 2. 5 vols. London: G. and W.B. Whittaker, 1819.

Edwards, Bryan, Arthur Broughton, and William Young. The History, Civil and Commercial, of the British Colonies in the West Indies. By Bryan Edwards, Esq. F.R.S. S.A. In Three Volumes. Vol. 2. 3 vols. London: Printed for John Stockdale, Piccadilly, 1801.

Edwards, Michael M. The Growth of the British Cotton Trade, 1780-1815. Manchester University Press, 1967.

Ehrman, John. The British Government and Commercial Negotiations with Europe 1783-1793. Cambridge University Press, 2013.

Eisenberg, Peter L. The Sugar Industry in Pernambuco: Modernization Without Change, 18401910. University of California Press, 1974. 
Ellison, Thomas. A Handbook of the Cotton Trade: Or a Glance at the Past History, Present Condition, and Future Prospects of the Cotton Commerce of the World. London: Longman, Brown, Green, Longmans, and Roberts, 1858.

- The Cotton Trade of Great Britain: Including a History of the Liverpool Cotton Market and of the Liverpool Cotton Brokers' Association. London: Effingham Wilson, 1886.

Eltis, David. "The Slave Economies of the Caribbean: Structure, Performance, Evolution and Significance.” In General History of the Caribbean, by Franklin W. Knight, 105-37. UNESCO, 1997.

Eltis, David, Frank D. Lewis, and David Richardson. "Slave Prices, the African Slave Trade, and Productivity in the Caribbean, 1674-1807." The Economic History Review 58, no. 4 (November 1, 2005): 673-700. doi:10.1111/j.1468-0289.2005.00318.x.

Engerman, Stanley. "40 Years of Slavery Studies." História Econômica \& História de Empresas 18, no. 1 (November 13, 2015).

Engerman, Stanley L. "Slavery and Its Consequences for the South in the Nineteenth Century." In The Cambridge Economic History of the United States: The Long Nineteenth Century, edited by Stanley L. Engerman and Robert E. Gallman, 2:329-66. Cambridge: Cambridge University Press, 2000.

Engerman, Stanley L., and Kenneth L. Sokoloff. "Factor Endowments, Inequality, and Paths of Development Among New World Economics.” Working Paper. National Bureau of Economic Research, October 2002. http://www.nber.org/papers/w9259.

Engerman, Stanley, Richard Sutch, and Gavin Wright. "Slavery." In Historical Statistics of the United States, Millennial Edition On Line., 2-369; 2-374. Cambridge University Press, 2006.

Filho, Heitor Pinto de Moura. "Câmbio de longo prazo do mil-réis: uma abordagem empírica referente às taxas contra a libra esterlina e o dólar (1795-1913)." Cadernos de História 11, no. 15 (2010): 9-34. doi:10.5752/P.2237-8871.2010v11n15p9.

Findlay, Ronald, and Kevin H. O'Rourke. Power and Plenty: Trade, War, and the World Economy in the Second Millennium. Princeton, N.J. ; Woodstock, Oxfordshire England: Princeton University Press, 2007.

Fisher, Harold E. S. The Portugal Trade: A Study of Anglo-Portuguese Commerce, 1700-1770. London: Methuen, 1971.

Flory, Thomas. Judge and Jury in Imperial Brazil, 1808-1871: Social Control and Political Stability in the New State. University of Texas Press, 2015.

Fogel, Robert William. Without Consent Or Contract: The Rise and Fall of American Slavery. Norton, 1994.

Ford, Lacy. "Reconfiguring the Old South: 'Solving' the Problem of Slavery, 1787-1838." The Journal of American History 95, no. 1 (June 1, 2008): 95-122. doi:10.2307/25095466.

Fragoso, João. "Mercados e Negociantes Imperiais: Um Ensaio Sobre a Economia do Império Português (Séculos XVII e XIX).” História: Questões \& Debates 36, no. 1 (2002). http://ojs.c3sl.ufpr.br/ojs/index.php/historia/article/view/2690.

Fragoso, João Luís Ribeiro, and Manolo Florentino. O arcaísmo como projeto: mercado atlântico, sociedade agrária e elite mercantil em uma economia colonial tardia: Rio de Janeiro, c.1790-c.1840. Rio de Janeiro: Civilização Brasileira, 2001. 
Francis, Alan David. Portugal 1715-1808: Joanine, Pombaline and Rococo Portugal as Seen by British Diplomats and Traders. Tamesis, 1985.

Frank, Zephyr L. Dutra's World: Wealth and Family in Nineteenth-Century Rio de Janeiro. Albuquerque: University of New Mexico Press, 2004.

Frankel, Jeffrey A., and David Romer. "Does Trade Cause Growth?” The American Economic Review 89, no. 3 (1999): 379-99.

Furtado, Celso. Formação econômica do Brasil. Companhia das Letras, 2006.

Gama, Bernardo Jose da. Informação sobre a capitania de Maranhão, dada em 1813 ao chanceller Antonio Rodrigues Velloso,. Vienna d'Áustria: Impr. do filho de C. Gerold, 1872.

Gayoso, Raimundo José de Souza. Compendio Historico-Politico Dos Principios Da Lavoura Do Maranhão. Paris: Officina de P.-N. Rougeron, 1818.

Governo do Estado da Bahia. Cartas Economico-politicas sobre a agricultura e commercio da Bahia pelo Desembargador João Rodrigues de Brito, Deputado das Côrtes; e outros. Dadas á luz por I. A. F. Benevides. Lisboa: Imprensa Nacional, 1924.

Graham, Richard. "Slavery and Economic Development: Brazil and the United States South in the Nineteenth Century." Comparative Studies in Society and History 23, no. 4 (October 1, 1981): 620-55.

Gray, Lewis Cecil. History of Agriculture in the Southern United States to 1860. Vol. 2. 2 vols. Carnegie Institution of Washington, 1933.

Gregório, Vitor Marcos. “O Progresso a Vapor: Navegação E Desenvolvimento Na Amazônia Do Século XIX.” Nova Economia 19, no. 1 (April 2009): 185-212. doi:10.1590/S010363512009000100008.

Gudmestad, Robert. Steamboats and the Rise of the Cotton Kingdom. Baton Rouge: Louisiana State University Press, 2011.

Haber, Stephen. Crony Capitalism and Economic Growth in Latin America: Theory and Evidence. Hoover Institution Press, 2013.

Hall, Robert E., and Charles I. Jones. "Why Do Some Countries Produce So Much More Output Per Worker than Others?” The Quarterly Journal of Economics 114, no. 1 (February 1, 1999): 83-116. doi:10.1162/003355399555954.

Hanson, John R. "World Demand for Cotton during the Nineteenth Century: Wright's Estimates Re-Examined.” The Journal of Economic History 39, no. 4 (December 1979): 1015-21. doi:10.1017/S0022050700098739.

Harley, C. Knick. "Cotton Textile Prices and the Industrial Revolution." The Economic History Review 51, no. 1 (1998): 49-83.

. "Cotton Textile Prices Revisited: A Response to Cuenca Esteban." The Economic History Review 52, no. 4 (November 1, 1999): 756-65. doi:10.1111/1468-0289.00147. . "Ocean Freight Rates and Productivity, 1740-1913: The Primacy of Mechanical Invention Reaffirmed.” The Journal of Economic History 48, no. 04 (December 1988): 851-876. doi:10.1017/S0022050700006641.

. "Was Technological Change in the Early Industrial Revolution Schumpeterian? Evidence of Cotton Textile Profitability." Explorations in Economic History 49, no. 4 (October 2012): 516-27. doi:10.1016/j.eeh.2012.06.004. 
Hausmann, Ricardo, Bailey Klinger, and Rodrigo Wagner. "Doing Growth Diagnostics in Practice: A 'Mindbook." Harvard University Center for International Development Working Papers, no. Working Paper No. 177 (September 2008): 102.

Hawthorne, Walter. From Africa to Brazil: Culture, Identity, and an Atlantic Slave Trade, 16001830. Cambridge ; New York: Cambridge University Press, 2010.

Henneberry, Shida Rastegari, and Seong-huyk Hwang. "Meat Demand in South Korea: An Application of the Restricted Source-Differentiated Almost Ideal Demand System Model." Journal of Agricultural and Applied Economics 39, no. 1 (April 2007): 47-60. doi:10.1017/S1074070800022744.

Hickey, Donald R. "American Trade Restrictions during the War of 1812." The Journal of American History 68, no. 3 (December 1, 1981): 517-38. doi:10.2307/1901937.

Hoffman, Philip T. "What Do States Do? Politics and Economic History." The Journal of Economic History 75, no. 2 (June 2015): 303-32. doi:10.1017/S0022050715000637.

Howe, Daniel Walker. What Hath God Wrought: The Transformation of America, 1815-1848. New York: Oxford University Press, 2007.

Hudson, Pat. The Industrial Revolution. Reading History. London ; New York : New York, NY: E. Arnold ; Distributed in the USA by Routledge, Chapman, and Hall, 1992.

Hunt, Roger. Observations upon Brazil Cotton Wool ... with a View to Its Improvement. London: Steel, Printer, 1808.

Imlah, Albert H. "Real Values in British Foreign Trade, 1798-1853." The Journal of Economic History 8, no. 02 (November 1948): 133-152. doi:10.1017/S0022050700069473.

Inikori, Joseph E., and Stanley L. Engerman. The Atlantic Slave Trade: Effects on Economies, Societies and Peoples in Africa, the Americas, and Europe. Duke University Press, 1992.

Irigoin, Alejandra. "Representation without Taxation, Taxation without Consent: The Legacy of Spanish Colonialism in America." Revista de Historia Económica (New Series) 34, no. 02 (September 2016): 169-208. doi:10.1017/S0212610916000069.

Irigoin, María Alejandra. "Macroeconomic Aspects of Spanish American Independence : The Effects of Fiscal and Currency Fragmentation, 1800s-1860s.” IFCS - Working Papers in Economic History.WH. Universidad Carlos III de Madrid. Instituto Figuerola, 2003. https://ideas.repec.org/p/cte/whrepe/wh034509.html.

Irwin, Douglas A. "The Optimal Tax on Antebellum US Cotton Exports." Journal of International Economics 60, no. 2 (August 2003): 275-91. doi:10.1016/S00221996(02)00052-1.

Irwin, Douglas A. "The Welfare Cost of Autarky: Evidence from the Jeffersonian Trade Embargo, 1807-09.” Review of International Economics 13, no. 4 (September 1, 2005): 631-45. doi:10.1111/j.1467-9396.2005.00527.x.

Jensen, Jeffrey L. "Initial Institutions, Institutional Persistence, and the Promotion of Economic Development by the Original 13 States." PhD Dissertation, New York University, 2010.

Jeremy, David J. Transatlantic Industrial Revolution: The Diffusion of Textile Technologies between Britain and America, 1790-1830s. First Edition, First Printing edition. North Andover, Mass. : Cambridge, Mass: The MIT Press, 1981. 
Johnson, Noel D., and Mark Koyama. "States and Economic Growth: Capacity and Constraints." Explorations in Economic History 64, no. April (2017): 1-20. doi:10.1016/j.eeh.2016.11.002.

. "Tax Farming and the Origins of State Capacity in England and France." Explorations in Economic History 51 (January 2014): 1-20. doi:10.1016/j.eeh.2013.07.005.

Johnson, Walter. River of Dark Dreams. Cambridge: Harvard University Press, 2013.

Killick, John R. "The Cotton Operations of Alexander Brown and Sons in the Deep South, 1820-1860." The Journal of Southern History 43, no. 2 (1977): 169-94. doi:10.2307/2207344.

Klein, Herbert S., and Francisco Vidal Luna. Slavery in Brazil. Cambridge University Press, 2010.

Koster, Henry. Travels in Brazil. London: Longman, Hurst, Rees, Orme, and Brown, Paternoster-Row., 1816.

Krichtal, Alexey. "Liverpool and the Raw Cotton Trade: A Study of the Port and Its Merchant Community, 1770-1815." Victoria University of Wellington, 2013.

Lago, Antônio Bernardino Pereira do. Estatística histórico-geográfica da província do Maranhão. Editora Siciliano, 1822.

. “Itinerário Da Província Do Maranhão.” Revista Do IHGB Tomo XXXV (1872): 385422.

Lakwete, Angela. Inventing the Cotton Gin: Machine and Myth in Antebellum America. JHU Press, 2005.

Lang, James. Portuguese Brazil: The King's Plantation. Academic Press, 1979.

Lazonick, William. "Factor Costs and the Diffusion of Ring Spinning in Britain Prior to World War I." The Quarterly Journal of Economics 96, no. 1 (1981): 89-109. doi:10.2307/2936142.

Leal, Victor Nunes. Coronelismo, enxada e voto. 7th ed. São Paulo: Editora Companhia das Letras, 2012.

Leff, Nathaniel H. "A Technique for Estimating Income Trends from Currency Data and an Application to Nineteenth-Century Brazil." Review of Income and Wealth 18, no. 4 (December 1, 1972): 355-68. doi:10.1111/j.1475-4991.1972.tb00962.x.

- "Economic Development and Regional Inequality: Origins of the Brazilian Case." The Quarterly Journal of Economics 86, no. 2 (1972): 243-62. doi:10.2307/1880562.

_. "Economic Development in Brazil, 1822-1913." In How Latin Amrica Fell Behind: Essays on the Economic Histories of Brazil and Mexico, 1800-1914, edited by Stephen H. Haber, 34-64. Stanford: Stanford University Press, 1997.

Lepler, Jessica M. The Many Panics of 1837: People, Politics, and the Creation of a Transatlantic Financial Crisis. New York, NY: Cambridge University Press, 2013.

Lindert, Peter H., and Jeffrey G. Williamson. Unequal Gains: American Growth and Inequality since 1700. Princeton: Princeton University Press, 2016.

Lisboa, José da Silva. Observações Sobre a Franqueza Da Indústria, E Estabelecimento de Fábricas No Brasil. Brasília: Senado Federal, 1999.

Llorca-Jaña, Manuel. The British Textile Trade in South America in the Nineteenth Century. Cambridge ; New York: Cambridge University Press, 2012. 
Lobo, Eulalia Maria Lahmeyer, Lucena Barbosa Madureira, Octavio Canavarros, Zakia Feres, and Sonia Gonçalves. "Evolução Dos Preços E Do Padrão de Vida No Rio de Janeiro, 1820-1930 - Resultados Preliminares." Revista Brasileira de Economia 25, no. 4 (October 1, 1971): 235-66.

Ludington, Charles. The Politics of Wine in Britain: A New Cultural History. Palgrave Macmillan, 2013.

Luna, Francisco Vidal, and Herbert S. Klein. "Slave Economy and Society in Minas Gerais and São Paulo, Brazil in 1830." Journal of Latin American Studies 36, no. 01 (February 2004): 1-28. doi:10.1017/S0022216X03007053.

Macedo, Jorge Borges de. O bloqueio continental: economia e guerra peninsular. Gradiva, 1990.

Mackenzie, Charles. Facts, Relative to the Present State of the British Cotton Colonies: And to the Connection of Their Interests with Those of the Mother Country. Edinburgh: T. Bryce \& Co, 1811. http://uclibs.org/PID/126171.

Macpherson, David, and Adam Anderson. Annals of Commerce, Manufactures, Fisheries, and Navigation, with Brief Notices of the Arts and Sciences Connected with Them. Vol. 4. 4 vols. London: Nichols, 1805.

Majewski, John. "Why Did Northerners Oppose the Expansion of Slavery? Economic Development and Education in the Limestone South." In Slavery's Capitalism: A New History of American Economic Development, edited by Sven Beckert and Seth Rockman, 277-98. Philadelphia: University of Pennsylvania Press, 2016.

Malheiro, Agostinho Marques Perdigão. A escravidão no Brasil : ensaio historico-juridicosocial. Vol. 3. Rio de Janeiro: Typographia Nacional, 1867. http://www2.senado.leg.br/bdsf/handle/id/174437.

Mancall, Peter C., Joshua L. Rosenbloom, and Thomas Weiss. "Slave Prices and the South Carolina Economy, 1722-1809." The Journal of Economic History 61, no. 03 (September 2001): 616-639. doi:null.

Manchester, Alan Krebs. British Preeminence in Brazil: Its Rise and Decline: A Study in European Expansion. Octagon Books, 1964.

Mann, James A. The Cotton Trade of Great Britain: Its Rise, Progress and Present Extent. Simpkin, Marshall, 1860.

Marcondes, Renato Leite. Diverso E Desigual: O Brasil Escravista Na Década de 1870. FUNPEC, 2009.

—. "Posse de Cativos No Interior Do Maranhão (1848)." Revista Do Instituto Arqueológico, Histórico E Geográfico Pernambucano, no. 61 (July 2005): 169-86.

Marler, Scott P. The Merchants' Capital: New Orleans and the Political Economy of the Nineteenth-Century South. Cambridge ; New York: Cambridge University Press, 2013.

Marques, Cesar Augusto. Diccionario historico-geographico da provincia do Maranhão. Maranhão: Typ. do Frias, 1870. http://www2.senado.leg.br/bdsf/handle/id/221726.

Mattoso, Kátia M. de Queirós, Herbert S. Klein, and Stanley L. Engerman. "Research Note: Trends and Patterns in the Prices of Manumitted Slaves: Bahia, 1819-1888." Slavery \& Abolition 7, no. 1 (May 1, 1986): 59-67. doi:10.1080/01440398608574903.

Maxwell, Kenneth. Conflicts and Conspiracies: Brazil and Portugal, 1750-1808. Routledge, 2004. 
. Pombal, Paradox of the Enlightenment. CUP Archive, 1995.

McCloskey, D. N. “The Industrial Revolution 1780-1860: A Survey.” In The Economic History of Britain Since 1700, 103-27. Cambridge: Cambridge University Press, 1981.

McCloskey, Deirdre N. Bourgeois Dignity: Why Economics Can't Explain the Modern World. University of Chicago Press, 2011.

."How the West (and the Rest) Got Rich." Wall Street Journal, May 20, 2016, sec. Life. http://www.wsj.com/articles/why-the-west-and-the-rest-got-rich-1463754427.

Mehlum, Halvor, Karl Moene, and Ragnar Torvik. "Institutions and the Resource Curse." The Economic Journal 116, no. 508 (January 1, 2006): 1-20. doi:10.1111/j.14680297.2006.01045.x.

Mello, Evaldo Cabral de. A outra independência: o federalismo pernambucano de 1817 a 1824. Editora 34, 2004.

Mello, José Antônio Gonsalves de, ed. O Diario de Pernambuco E a História Social Do Nordeste (1840-1889). Vol. 2. 2 vols. Recife: O Diario de Pernambuco, 1975.

Mello, María Regina Ciparrone. A industrialização do algodão em São Paulo. Editora Perspectiva, 1983.

Menezes, José Pedro Cesar. "Roteiro Para Seguir a Melhor Estrada Do Maranhão Para a Côrte Do Rio de Janeiro.” Revista Do IHGB Tomo III (1841): 512-14.

Mesquita, Francisco de Assis Leal. Vida e morte da economia algodoeira do Maranhão: uma análise das relações de produção na cultura do algodão, 1850/1890. Universidade Federal do Maranhão, 1987.

Michaels, Guy. "The Long Term Consequences of Resource-Based Specialisation." The Economic Journal 121, no. 551 (March 1, 2011): 31-57. doi:10.1111/j.14680297.2010.02402.x.

Miller, Joseph C. "Slave Prices in the Portuguese Southern Atlantic, 1600-1830." In Africans in Bondage: Studies in Slavery and the Slave Trade, by Paul E. Lovejoy. Madison: African Studies Program, University of Wisconsin, 1986.

Miller, Rory. Britain and Latin America in the Nineteenth and Twentieth Centuries. 1 edition. London; New York: Routledge, 1995.

Mokyr, Joel. The Enlightened Economy: An Economic History of Britain 1700-1850. New Haven: Yale University Press, 2012.

. The Enlightened Economy: Britain and the Industrial Revolution, 1700-1850. Penguin UK, 2011.

Moog, Clodomir Vianna. Bandeirantes e pioneiros : paralelo entre duas culturas. Rio de Janeiro : Editôra Globo, 1957.

Moore, John Hebron. The Emergence of the Cotton Kingdom in the Old Southwest: Mississippi, 1770-1860. LSU Press, 1988.

Morris, Charles R. The Dawn of Innovation: The First American Industrial Revolution. New York: PublicAffairs, 2012.

Mota, Antonia da Silva. As Famílias Principais Redes de Poder No Maranhão Colonial. São Luís: EDUFMA, 2012.

Mota, Antonia da Silva, and Daniel Souza Barroso. "Economia e demografia da escravidão no Maranhão e no Grão-Pará: uma análise comparativa da estrutura da posse de cativos 
(1785-1850)." Revista de História, no. 176 (January 27, 2017): 01-41. doi:10.11606/issn.2316-9141.rh.2017.121833.

North, Douglass C. The Economic Growth of the United States: 1790-1860. First Edition. New York: W. W. Norton \& Company, 1966.

North, Douglass C., and Barry R. Weingast. "Constitutions and Commitment: The Evolution of Institutions Governing Public Choice in Seventeenth-Century England.” The Journal of Economic History 49, no. 4 (1989): 803-32.

Novais, Fernando A. Portugal e Brasil na crise do antigo sistema colonial (1777-1808). Editora HUCITEC, 1979.

Nunn, Nathan. "Historical Development." In Handbook of Economic Growth, edited by Philippe Aghion and Steven N. Durlauf, 2:347-402. Handbook of Economic Growth. Elsevier, 2014. http://www.sciencedirect.com/science/article/pii/B9780444535382000071.

- "Slavery, Inequality and Economic Development in the Americas: An Examination of the Engerman-Sokoloff Hypothesis." In Institutions and Economic Performance, edited by Elhanan Helpman, 148-80. Harvard University Press, 2009.

O'Brien, Patrick, Trevor Griffiths, and Philip Hunt. "Political Components of the Industrial Revolution: Parliament and the English Cotton Textile Industry, 1660-1774." The Economic History Review 44, no. 3 (1991): 395-423. doi:10.2307/2597536.

Oliveira, Candido Baptista de. Systema financial do Brasil. S. Petersburgo: Typographia Privilegiada de Fischer, 1842.

Oliveira Lima, Manuel de. Dom Joao VI no Brazil, 1808-1821. Rio de Janeiro: Typ. do Jornal do commercio, 1908.

Oliverira, Guilherme de, and Carmine Guerriero. "Extractive States: The Case of the Italian Unification.” Working Paper. Columbia Law School, February 10, 2017.

Olmstead, Alan L., and Paul W. Rhode. "Biological Innovation and Productivity Growth in the Antebellum Cotton Economy." The Journal of Economic History 68, no. 04 (December 2008): 1123-1171. doi:10.1017/S0022050708000831.

O'Rourke, Kevin H. "The Worldwide Economic Impact of the French Revolutionary and Napoleonic Wars, 1793-1815.” Journal of Global History 1, no. 01 (2006): 123-149. doi:10.1017/S1740022806000076.

Panza, Laura, and Jeffrey G. Williamson. "Did Muhammad Ali Foster Industrialization in Early Nineteenth-Century Egypt?" The Economic History Review 68, no. 1 (February 1, 2015): 79-100. doi:10.1111/1468-0289.12063.

Parthasarathi, Prasannan. Why Europe Grew Rich and Asia Did Not: Global Economic Divergence, 1600-1850. Cambridge University Press, 2011.

Pearce, Adrian J. British Trade with Spanish America, 1763-1808. Liverpool University Press, 2007.

Pedreira, Jorge M. "From Growth to Collapse: Portugal, Brazil, and the Breakdown of the Old Colonial System (1760-1830)." Hispanic American Historical Review 80, no. 4 (November 1, 2000): 839-64. doi:10.1215/00182168-80-4-839.

Pedreira, Jorge Miguel Viana. “Os Homens de Negócio Da Praça de Lisboa de Pombal Ao Vintismo (1755-1822): Diferenciação, Reprodução E Identificação de Um Grupo Social." FCSH, 1995. 
Peláez, Carlos Manuel, and Wilson Suzigan. História monetária do Brasil. Brasília: Editora Universidade de Brasília, 1981.

Pereira, Thales A. Zamberlan. "Was It Uruguay or Coffee? The Causes of the Beef Jerky Industry's Decline in Southern Brazil (1850 - 1889)." Nova Economia 26, no. 1 (April 2016): 7-42. doi:10.1590/0103-6351/3005.

Phillips, Ulrich Bonnell, and John David Smith. Life and Labor in the Old South. Columbia,

S.C: University of South Carolina Press, 2007.

Platiere, Roland de La. Encyclopédie méthodique: Manufactures, arts et métiers. Paris: Panckoucke libraire, 1785.

Platt, D. C. M. Latin America and British Trade, 1806-1914: The Merchant Adventurers. Harper \& Row, 1973.

. "The Imperialism of Free Trade: Some Reservations." The Economic History Review 21, no. 2 (August 1968): 296. doi:10.2307/2592437.

Pomeranz, Kenneth. The Great Divergence: China, Europe, and the Making of the Modern World Economy. Princeton University Press, 2009.

Porter, George Richardson. The Progress of the Nation. London: C. Knight \& Co., 1836.

Prado Jr, Caio. Formação do Brasil contemporâneo. Editora Brasiliense, 1948.

Prado Jr., Caio. História econômica do Brasil. Rio de Janeiro: Editôra Brasiliense, 1972.

Prados De La Escosura, Leandro. "Lost Decades? Economic Performance in PostIndependence Latin America.” Journal of Latin American Studies 41, no. 02 (2009): 279-307. doi:10.1017/S0022216X09005574.

Price, Jacob M. "What Did Merchants Do? Reflections on British Overseas Trade, 1660-1790." The Journal of Economic History 49, no. 02 (June 1989): 267-284. doi:10.1017/S0022050700007920.

Puga, Diego, and Daniel Trefler. "International Trade and Institutional Change: Medieval Venice's Response to Globalization." The Quarterly Journal of Economics 129, no. 2 (May 1, 2014): 753-821. doi:10.1093/qje/qju006.

Radcliffe, William. Origin of the New System of Manufacture: Commonly Called "power-Loom Weaving," and the Purposes for Which This System Was Invented and Brought into Use, Fully Explained in a Narrative, Containing William Radcliffe's Struggles through Life to Remove the Cause Which Has Brought This Country to Its Present Crisis. Stockport: J. Lomax, 1828.

Recenseamento do Brasil, 1920. Resumo Histórico Dos Inquéritos Censitários Realizados No Brasil. Ed. fac-Similada. São Paulo: Instituto de Pesquisas Econômicas, 1986.

Rees, Abraham. "Cotton." In The Cyclopadia; Or, Universal Dictionary of Arts, Sciences, and Literature. London: Longman, Hurst, Rees, Orme \& Brown, 1819.

Reidy, Joseph P. "Inventing the Cotton Gin: Machine and Myth in Antebellum America. By Angela Lakwete." The Journal of American History 91, no. 4 (2005): 1452-53. doi: $10.2307 / 3660219$.

Reidy, Joseph Patrick. From Slavery to Agrarian Capitalism in the Cotton Plantation South: Central Georgia, 1800-1880. Chapel Hill: University of North Carolina Press, 1992.

Reis, Antonio Henoch dos. Camara Dos Srs. Deputados. Terceiro Anno Da Quarta Legislatura. Sessão de 1840. Rio de Janeiro: Typographia da Viuva Pinto \& Filho, 1884. 
Resende, Guilherme, Flávio Rabelo Versiani, Luiz Paulo Ferreira Nogueról, and José Raimundo Oliveira Vergolino. "Preços de Escravos E E Produtividade Do Trabalho Cativo: Pernambuco E Rio Grande Do Sul, Século XIX." Anais do XLI Encontro Nacional de Economia [Proceedings of the 41th Brazilian Economics Meeting]. ANPEC - Associação Nacional dos Centros de Pósgraduação em Economia [Brazilian Association of Graduate Programs in Economics], 2014. http://econpapers.repec.org/paper/anpen2013/030.htm.

Ricupero, Rubens. "O problema da Abertura dos Portos." In A abertura dos portos. São Paulo: Editora Senac São Paulo, 2007.

Riello, Giorgio. Cotton: The Fabric That Made the Modern World. Cambridge University Press, 2013.

Riello, Giorgio, and Tirthankar Roy. How India Clothed the World: The World of South Asian Textiles, 1500-1850. BRILL, 2009.

Robson, Martin. Britain, Portugal and South America in the Napoleonic Wars: Alliances and Diplomacy in Economic Maritime Conflict. London: I. B. Tauris, 2011.

Rothman, Adam. Slave Country: American Expansion and the Origins of the Deep South. Harvard University Press, 2005.

Royle, John Forbes. On the Culture and Commerce of Cotton in India and Elsewhere; with an Account of the Experiments Made by the Hon. East India Company up to the Present Time. London: Smith, Elder, 1851.

Sargen, Ian. Our Men in Brazil: The Hesketh Brothers Abroad. Scotforth Books, 2009.

Saunders, Gail. Slavery in the Bahamas, 1648-1838. D. Gail Saunders, 2000.

Schwartz, Stuart B. "Patterns of Slaveholding in the Americas: New Evidence from Brazil." The American Historical Review 87, no. 1 (1982): 55-86. doi:10.2307/1863308.

Shillington, Violet Mary, and Annie Beatrice Wallis Chapman. The Commercial Relations of England and Portugal. G.Routledge \& sons, 1907.

Silva, Andrée M. “Imperial Re-Organization, 1750-1808." In Colonial Brazil, edited by Leslie Bethell, 244-83. Cambridge ; New York: Cambridge University Press, 1987.

Silva, Daniel B. Domingues da. "The Atlantic Slave Trade to Maranhão, 1680-1846: Volume, Routes and Organisation." Slavery \& Abolition 29, no. 4 (December 1, 2008): 477-501. doi:10.1080/01440390802486507.

Silva, Joaquim Norberto de Souza e. Investigações Sobre Os Recenseamentos Da População Geral Do Império E de Cada Província de per Si Tentados Desde Os Tempos Coloniais Até Hoje. Ed. fac-Similada. São Paulo: Instituto de Pesquisas Econômicas, 1986.

Simonsen, Roberto. História Econômica Do Brasil (1500/1820). Rio de Janeiro: Brasiliana, 1967.

Smithers, Henry. Liverpool, Its Commerce, Statistics, and Institutions: With a History of the Cotton Trade. T. Kaye, 1825.

Soares, Mariza de Carvalho, and Priscilla Leal Mello Mello. “'O resto predeu-se'? História e Folclore: O Caso dos Muçulmanos das Alagoas." In Visibilidades negras, 14-26. UFAL, 2006.

Soares, Sebastião Ferreira. "BRAZIL: Report. Cultivation of Cotton," July 23, 1861. FO 881/1003. The National Archives, Kew. 
Sokoloff, Kenneth, and Eric Zolt. "Inequality and the Evolution of Institutions of Taxation: Evidence from the Economic History of the Americas." In The Decline of Latin American Economies: Growth, Institutions, and Crises, by Sebastian Edwards, Gerardo Esquivel, and Graciela Márquez, 83-138. Chicago: The University of Chicago Press, 2007.

Steckel, Richard H. The Economics of U.S. Slave and Southern White Fertility. New York: Garland, 1985.

Stein, Stanley J. Origens e evolução da indústria têxtil no Brasil: 1850-1950. Rio de Janeiro: Editora Campus, 1979.

- Vassouras, a Brazilian Coffee County, 1850-1900: The Roles of Planter and Slave in a Plantation Society. Princeton University Press, 1985.

Stiglitz, Joseph E. "Rational Peasants, Efficient Institutions, and a Theory of Rural Organization: Methodological Remarks for Development Economics." In The Economic Theory of Agrarian Institutions, by Pranab K. Bardhan, 18-30. Oxford: Clarendon Press, 1991.

Sturz, Johann Jakob. A Review Financial, Statistical and Commercial of the Empire of Brazil and Its Resources; Together with a Suggestion of the Expediency and Mode of Admitting Brazilian and Other Foreign Sugars Into Great Britain. London: E. Wilson, 1837.

Styles, John. "Fashion, Textiles and the Origins of Industrial Revolution." East Asian Journal of British History 5 (March 31, 2016): 161-89.

Summerhill, William R. Inglorious Revolution: Political Institutions, Sovereign Debt, and Financial Underdevelopment in Imperial Brazil. New Haven: Yale University Press, 2015.

Tanzi, Vito. "Export Taxation in Developing Countries: Taxation of Coffee in Haiti." Social and Economic Studies 25, no. 1 (1976): 66-76.

Taunay, Carlos Augusto, and Padre Antonio Caetano da Fonseca. Tratado da cultura do algodoeiro no Brasil ou arte de tirar vantagens dessa plantação. Rio de Janeiro: Eduardo \& Henrique Laemmert, 1862.

Taunay, Carlos Augusto, and L. Riedel. Manual do Agricultor Brazileiro. 2nd ed. Rio de Janeiro: Typographia Imperial, 1839.

Tavares Bastos, Aureliano Cândido. A provincia; estudo sobre a descentralisação no Brazil. Rio de Janeiro, B.L. Garnier, 1870.

Taylor, Alan. The Internal Enemy: Slavery and War in Virginia, 1772-1832. 1 edition. New York: W. W. Norton \& Company, 2013.

Temin, Peter. "Two Views of the British Industrial Revolution." The Journal of Economic History 57, no. 1 (1997): 63-82.

“The Trans-Atlantic Slave Trade Database.” Voyages Database. Accessed January 5, 2015. http://www.slavevoyages.org/.

Thorpe, T. B. “Sea Island Cotton.” Harper's New Monthly Magazine, April 17, 1869.

Tollenare, Louis-François. Notas dominicaes tomadas durante uma residencia em Portugal e no Brasil nos annos 1816, 1817 e 1818. Impreza do Jornal do Recife, 1905. 
Treasure Department. Letter from the Secretary of the Treasury, Transmitting Tables and Notes on the Cultivation, Manufacture, and Foreign Trade of Cotton. Washington, D.C.: Gales \& Sraton, 1836.

Turner, A. Manual Do Plantador D’algodão,. Maranhão: Officina Typographica do Frias, 1859. http://hdl.handle.net/2027/coo.31924016403341.

Velloso de Oliveira, Antonio Rodrigues. "A Igreja Do Brasil.” Revista Do IHGB XXIX, no. Parte Primeira (1866): 159-200.

Versiani, Flávio Rabelo, and José Raimundo Oliveira Vergolino. "Posse de Escravos E Estrutura Da Riqueza No Agreste E Sertão de Pernambuco: 1777-1887." Estudos Econômicos (São Paulo) 33, no. 2 (June 2003): 353-93. doi:10.1590/S010141612003000200005.

Vieira da Silva, Luís Antônio. História da independência da Província do Maranhão, 18221828. Rio de Janeiro: Companhía Editôra Americana, 1862.

Villela, André. "Distribuição Regional Das Receitas E Despesas Do Governo Central No II Reinado, 1844-1889.” Estudos Econômicos (São Paulo) 37, no. 2 (June 2007): 247-74. doi:10.1590/S0101-41612007000200001.

Villela, André Arruda. "Exclusivo Metropolitano, 'superlucros' e Acumulação Primitiva Na Europa Pré-Industrial.” Topoi (Rio de Janeiro) 12, no. 23 (December 2011): 4-29. doi:10.1590/2237-101X012023001.

Viveiros de Castro, Augusto Olympio. "Historia Tributaria Do Brasil." Revista Trimestral Do Instituto Histórico E Geográfico Brasileiro LXXVIII, no. Parte 1 (1916): 9-286.

Viveiros, Jerônimo de. História do comércio do Maranhão. Vol. 1. São Luís: Associação Comercial Maranhão, 1954.

História do comércio do Maranhão. Vol. 2. São Luís: Associação Comercial Maranhão, 1954.

Wadsworth, Alfred P., and Julia De Lacy Mann. The Cotton Trade and Industrial Lancashire, 1600-1780. Manchester University Press, 1965.

Wahl, Thomas I., and Dermot J. Hayes. "Demand System Estimation with Upward-Sloping Supply." Canadian Journal of Agricultural Economics/Revue Canadienne D'agroeconomie 38, no. 1 (March 1, 1990): 107-22. doi:10.1111/j.17447976.1990.tb03451.x.

Wallis, John Joseph. "The National Era." In Government and the American Economy: A New History, edited by Price V. Fishback, 148-87. Chicago: University of Chicago Press, 2008.

Ward, J. R. British West Indian Slavery, 1750-1834: The Process of Amelioration. Clarendon Press, 1988.

Wilcken, Patrick. Império à deriva: a corte portuguesa no Rio de Janeiro, 1808-1821. Rio de Janeiro: Editora Objetiva, 2005.

Williamson, Jeffrey G. "Review Essay on British Economic Growth, 1270-1870; by Stephen Broadberry, Bruce M. S. Campbell, Alexander Klein, Mark Overton, and Bas van Leeuwen." Journal of Economic Literature 54, no. 2 (June 2016): 514-21. doi:10.1257/jel.54.2.514.

Woodhouse, Thomas. Yarn Counts and Calculations. H. Frowde and Hodder \& Stoughton, 1921. 
Wright, Gavin. "An Econometric Study of Cotton Production and Trade, 1830-1860." The Review of Economics and Statistics 53, no. 2 (1971): 111-20. doi:10.2307/1925706. "River of Dark Dreams: Slavery and Empire in the Cotton Kingdom." Journal of Economic Literature 52, no. 3 (September 1, 2014): 877-79. doi:10.1257/jel.52.3.851.r16. . "The Efficiency of Slavery: Another Interpretation." The American Economic Review 69, no. 1 (1979): 219-26.

. The Political Economy of the Cotton South: Households, Markets, and Wealth in the Nineteenth Century. Norton, 1978. 


\section{Appendix}

Table A.1 - Cotton market and the exchange rate for Maranhão, 1809-1860

\begin{tabular}{|c|c|c|c|c|}
\hline Year & $\begin{array}{l}\text { Quantity exported } \\
\text { in Maranhão } \\
\text { (arrobas) }\end{array}$ & $\begin{array}{l}\text { Average price } \\
\text { in Maranhão } \\
\text { (mil-réis) }\end{array}$ & $\begin{array}{l}\text { Average price } \\
\text { Maranhão in } \\
\text { Liverpool (pence) }\end{array}$ & $\begin{array}{l}\text { Exchange rate in } \\
\text { Maranhão (pence) }\end{array}$ \\
\hline 1809 & 402,244 & 4000 & 19.3 & 78.2 \\
\hline 1810 & 285,863 & 3800 & 23.9 & 79.1 \\
\hline 1811 & 298,582 & 3400 & 13.3 & 77.5 \\
\hline 1812 & 217,754 & 3050 & 17.0 & 80.4 \\
\hline 1813 & 326,693 & 3800 & 21.6 & 84.3 \\
\hline 1814 & 248,380 & 4550 & 25.3 & 95.4 \\
\hline 1815 & 277,879 & 5700 & 23.0 & 80.6 \\
\hline 1816 & 350,257 & 6500 & 21 & 62.6 \\
\hline 1817 & 401,729 & 8500 & 22.5 & 67.8 \\
\hline 1818 & 402,793 & 8000 & 23 & 77.5 \\
\hline 1819 & 359,280 & 7600 & 20.5 & 71.5 \\
\hline 1820 & 367,193 & 5150 & 16 & 62.1 \\
\hline 1821 & 226,118 & 4075 & 11.5 & 55.3 \\
\hline 1822 & 295,757 & 3900 & 11 & 57.0 \\
\hline 1823 & 181,335 & 3625 & 9.5 & 52.0 \\
\hline 1824 & 264,281 & 4024 & 10.5 & 55.8 \\
\hline 1825 & 417,527 & 5577 & 14.5 & 60.5 \\
\hline 1826 & 179,345 & 4510 & 9.3 & 50.5 \\
\hline 1827 & 333,811 & 3600 & 8.4 & 51.0 \\
\hline 1828 & 373,542 & 3200 & 7.7 & 46.3 \\
\hline 1829 & 379,289 & 2836 & 6.5 & 45.0 \\
\hline 1830 & 454,294 & 3197 & 7.5 & 43.8 \\
\hline 1831 & 314,109 & 3160 & 7.0 & 44.0 \\
\hline 1832 & 274,972 & 3742 & 8.3 & 45.0 \\
\hline 1833 & 367,340 & $6773(5418)^{*}$ & 10.0 & 46.0 \\
\hline 1834 & 310,856 & $8560(5992)^{*}$ & 11.3 & 41.0 \\
\hline 1835 & 335,299 & $10680(5874)^{*}$ & 13.9 & 36.8 \\
\hline 1836 & 280,473 & 6615 & 11.93 & 36.0 \\
\hline 1837 & 225,647 & 6208 & 9.08 & 33.0 \\
\hline 1838 & 235,132 & 7235 & 8.53 & 28.2 \\
\hline 1839 & 131,730 & 6700 & 9.29 & 30.5 \\
\hline 1840 & 130,877 & 6622 & 8.79 & 30.3 \\
\hline 1841 & 281,008 & 5933 & 7.78 & 30.0 \\
\hline 1842 & 305,477 & 5300 & 6.21 & 27.9 \\
\hline 1843 & 245,548 & 4640 & 5.56 & 25.8 \\
\hline 1844 & 294,428 & 5000 & 5.71 & 25.0 \\
\hline 1845 & 308,725 & 4900 & 5.62 & 24.8 \\
\hline 1846 & 321,173 & 5270 & 6.32 & 25.6 \\
\hline 1847 & 290,351 & 6660 & 7.31 & 26.9 \\
\hline 1848 & 291,979 & 5520 & 5.26 & 25.9 \\
\hline 1849 & 317,113 & 4530 & 5.42 & 24.9 \\
\hline 1850 & 400,959 & 6225 & 7.22 & 26.7 \\
\hline 1851 & 344,449 & 6872 & 7.50 & 28.3 \\
\hline
\end{tabular}




\begin{tabular}{lllll}
1852 & 245,465 & 5840 & 6.00 & 27.7 \\
1853 & 263,152 & 6000 & 6.50 & 27.4 \\
1854 & 387,004 & 5850 & 5.50 & 27.5 \\
1855 & 315,001 & 6055 & 5.50 & 27.0 \\
1856 & 377,882 & 6285 & 5.50 & 27.0 \\
1857 & 259,309 & 7490 & 7.50 & 26.5 \\
1858 & 273,348 & 7820 & 6.50 & 25.5 \\
1859 & 216,838 & 8410 & 8.00 & 24.8 \\
1860 & 220,107 & 8700 & & 24.9 \\
\hline
\end{tabular}

* Corrected prices in silver exchange rate.

Sources: Foreign Office - British Consuls in Maranhão (1812-1842), Liverpool Mercury (British Newspaper Archive), Soares, Sebastião Ferreira. "BRAZIL: Report. Cultivation of Cotton," July 23, 1861. FO 881/1003. The National Archives, Kew. 
Table A.2 - Cotton imports into England, 1809-1860 (CUST 4) (pounds)

\begin{tabular}{|c|c|c|c|c|c|}
\hline Year & Brazil & U.S. & Year & Brazil & U.S. \\
\hline 1809 & $12,455,583$ & $26,645,881$ & 1850 & $30,048,144$ & $493,153,024$ \\
\hline 1810 & $9,843,130$ & $33,640,236$ & 1851 & & $596,638,896$ \\
\hline 1811 & $6,149,983$ & $25,789,497$ & 1852 & $25,732,000$ & $765,630,544$ \\
\hline 1812 & $9,105,205$ & $22,428,641$ & 1853 & $22,965,936$ & $658,451,696$ \\
\hline 1813 & & & 1854 & & \\
\hline 1814 & $22,405,845$ & 77,617 & 1855 & $23,736,944$ & $681,629,424$ \\
\hline 1815 & $13,002,429$ & $44,760,023$ & 1856 & $19,999,280$ & $780,040,016$ \\
\hline 1816 & $19,862,772$ & $45,125,269$ & 1857 & $28,686,560$ & $654,758,048$ \\
\hline 1817 & $16,119,384$ & $50,786,523$ & 1858 & $18,617,872$ & $833,237,776$ \\
\hline 1818 & $24,954,542$ & $57,799,606$ & 1859 & $21,654,304$ & $961,707,264$ \\
\hline 1819 & $20,860,865$ & $53,470,108$ & 1860 & $17,286,864$ & \\
\hline 1820 & $29,198,155$ & $79,654,151$ & & & \\
\hline 1821 & $19,430,108$ & $83,818,821$ & & & \\
\hline 1822 & $24,608,755$ & $90,371,141$ & & & \\
\hline 1823 & $23,514,641$ & $130,237,118$ & & & \\
\hline 1824 & $24,849,552$ & $81,530,216$ & & & \\
\hline 1825 & $33,180,491$ & $130,464,856$ & & & \\
\hline 1826 & $9,852,497$ & $122,177,432$ & & & \\
\hline 1827 & $20,716,162$ & $199,255,230$ & & & \\
\hline 1828 & $29,134,513$ & $141,079,848$ & & & \\
\hline 1829 & $28,878,386$ & $147,420,850$ & & & \\
\hline 1830 & $33,092,072$ & $210,885,358$ & & & \\
\hline 1831 & $31,695,761$ & $219,333,628$ & & & \\
\hline 1832 & $20,109,560$ & $219,756,753$ & & & \\
\hline 1833 & $28,463,821$ & $237,506,758$ & & & \\
\hline 1834 & $19,291,396$ & $269,203,075$ & & & \\
\hline 1835 & $24,986,409$ & $284,455,812$ & & & \\
\hline 1836 & $27,501,272$ & $289,615,692$ & & & \\
\hline 1837 & $20,940,145$ & $320,651,716$ & & & \\
\hline 1838 & $24,464,505$ & $431,437,888$ & & & \\
\hline 1839 & $16,971,979$ & $311,597,798$ & & & \\
\hline 1840 & $14,779,171$ & $487,856,504$ & & & \\
\hline 1841 & $16,671,348$ & $358,240,964$ & & & \\
\hline 1842 & $15,222,828$ & $414,030,779$ & & & \\
\hline 1843 & $18,675,104$ & $574,738,416$ & & & \\
\hline 1844 & $21,084,672$ & $517,218,576$ & & & \\
\hline 1845 & $20,157,536$ & $396,705,120$ & & & \\
\hline 1846 & $14,746,256$ & $401,949,296$ & & & \\
\hline 1847 & $19,966,912$ & $364,599,200$ & & & \\
\hline 1848 & $19,971,280$ & $600,247,424$ & & & \\
\hline 1849 & $30,603,104$ & $634,503,968$ & & & \\
\hline
\end{tabular}


Table A.3 - Cotton bales imports in Liverpool, 1821-1860

\begin{tabular}{|c|c|c|c|c|c|}
\hline Year & United States & East Indies & Egypt & Brazil & Other \\
\hline 1821 & 256,430 & 3,273 & - & 70,060 & 53,683 \\
\hline 1822 & 274,832 & 1,613 & - & 67,097 & 95,480 \\
\hline 1823 & 390,914 & 13,684 & - & 94,598 & 58,797 \\
\hline 1824 & 258,613 & 14,163 & 29,270 & 94,340 & 56,606 \\
\hline 1825 & 391,781 & 15,120 & 68,336 & 140,116 & 82,160 \\
\hline 1826 & 363,043 & 11,573 & 36,771 & 35,765 & 35,310 \\
\hline 1827 & 579,314 & 12,902 & 12,524 & 93,373 & 32,590 \\
\hline 1828 & 403,255 & 15,076 & 19,636 & 121,586 & 47,467 \\
\hline 1829 & 432,209 & 17,453 & 22,259 & 129,307 & 39,653 \\
\hline 1830 & 570,808 & 13,216 & 11,023 & 161,225 & 38,938 \\
\hline 1831 & 546,681 & 33,601 & 25,019 & 136,315 & 32,511 \\
\hline 1832 & 581,715 & 39,778 & 32,201 & 104,760 & 18,149 \\
\hline 1833 & 612,029 & 52,394 & 2,450 & 123,708 & 43,529 \\
\hline 1834 & 664,203 & 47,215 & 1,886 & 94,598 & 29,203 \\
\hline 1835 & 700,359 & 54,550 & 26,255 & 116,171 & 50,785 \\
\hline 1836 & 708,997 & 104,248 & 21,397 & 143,562 & 46,246 \\
\hline 1837 & 773,388 & 69,684 & 25,817 & 96,721 & 48,723 \\
\hline 1838 & $1,047,029$ & 60,592 & 22,830 & 94,468 & 74,287 \\
\hline 1839 & 787,914 & 82,800 & 17,029 & 66,649 & 57,300 \\
\hline 1840 & $1,165,270$ & 92,643 & 34,594 & 64,035 & 53,984 \\
\hline 1841 & 843,755 & 153,546 & 35,332 & 101,182 & 28,919 \\
\hline 1842 & 931,512 & 165,026 & 18,340 & 80,662 & 22,610 \\
\hline 1843 & $1,291,707$ & 108,729 & 45,649 & 96,314 & 29,516 \\
\hline 1844 & $1,138,141$ & 144,655 & 37,541 & 116,403 & 27,818 \\
\hline 1845 & $1,370,455$ & 86,888 & 64,027 & 107,249 & 11,559 \\
\hline 1846 & 933,735 & 49,521 & 60,767 & 78,278 & 10,575 \\
\hline 1847 & 819,909 & 121,552 & 17,563 & 109,574 & 8,101 \\
\hline 1848 & $1,284,759$ & 132,168 & 27,840 & 99,494 & 9,957 \\
\hline 1849 & $1,342,801$ & 106,987 & 70,117 & 154,996 & 7,070 \\
\hline 1850 & $1,108,010$ & 198,138 & 81,073 & 159,098 & 3,820 \\
\hline 1851 & $1,306,505$ & 228,109 & 65,774 & 104,295 & 3,914 \\
\hline 1852 & $1,646,806$ & 150,984 & 177,088 & 139,558 & 7,978 \\
\hline 1853 & $1,469,732$ & 315,792 & 102,797 & 143,524 & 6,287 \\
\hline 1854 & $1,584,502$ & 232,364 & 79,781 & 105,731 & 4,827 \\
\hline 1855 & $1,557,799$ & 279,865 & 110,077 & 131,454 & 4,466 \\
\hline 1856 & $1,703,613$ & 360,008 & 106,452 & 121,815 & 5,640 \\
\hline 1857 & $1,410,122$ & 556,376 & 70,277 & 168,872 & 6,260 \\
\hline 1858 & $1,758,468$ & 289,542 & 100,075 & 103,441 & 4,633 \\
\hline 1859 & $1,956,756$ & 430,124 & 99,850 & 117,895 & 4,273 \\
\hline 1860 & $2,492,138$ & 449,839 & 174,827 & 131,537 & 7,037 \\
\hline
\end{tabular}

Source: E. Donnell. Chronological and Statistical History of Cotton, 1872 
Table A.4 - Freight rates between MA, NY, and Liverpool, 1818-1850 (pence per pound)

\begin{tabular}{|c|c|c|}
\hline Year & New York to Liverpool & São Luís do Maranhão to Liverpool \\
\hline 1818 & & 0.78 \\
\hline 1819 & & 0.47 \\
\hline 1820 & & 0.52 \\
\hline 1821 & & 0.50 \\
\hline 1822 & 0.50 & \\
\hline 1823 & 0.67 & \\
\hline 1824 & 0.44 & 0.45 \\
\hline 1825 & 0.59 & 0.38 \\
\hline 1826 & 0.51 & 0.45 \\
\hline 1827 & 0.56 & 0.52 \\
\hline 1828 & 0.38 & 0.36 \\
\hline 1829 & 0.38 & 0.35 \\
\hline 1830 & 0.45 & 0.36 \\
\hline 1831 & 0.46 & 0.32 \\
\hline 1832 & 0.37 & 0.35 \\
\hline 1833 & 0.37 & \\
\hline 1834 & 0.34 & 0.28 \\
\hline 1835 & 0.36 & 0.35 \\
\hline 1836 & 0.37 & 0.34 \\
\hline 1837 & 0.48 & 0.39 \\
\hline 1838 & 0.48 & 0.41 \\
\hline 1839 & 0.41 & 0.30 \\
\hline 1840 & 0.53 & 0.34 \\
\hline 1841 & 0.32 & 0.36 \\
\hline 1842 & 0.28 & 0.34 \\
\hline 1843 & 0.37 & 0.23 \\
\hline 1844 & 0.36 & 0.27 \\
\hline 1845 & 0.31 & 0.27 \\
\hline 1846 & 0.30 & 0.28 \\
\hline 1847 & 0.35 & 0.33 \\
\hline 1848 & 0.18 & 0.26 \\
\hline 1849 & 0.21 & 0.24 \\
\hline 1850 & 0.16 & 0.24 \\
\hline
\end{tabular}

Sources: Foreign Office - British Consuls in Maranhão (1812-1842), Donnell, E. J. Chronological and Statistical History of Cotton. 
Table A.5 - Production costs for an arroba of cotton in Maranhão, 1809-1860

\begin{tabular}{|c|c|c|c|c|c|}
\hline Year & $\begin{array}{l}\text { Freight } \\
\text { (réis) }\end{array}$ & $\begin{array}{l}\text { Arrobas per } \\
\text { bag }\end{array}$ & $\begin{array}{l}\text { Slave Prices } \\
\text { (réis) }\end{array}$ & $\begin{array}{l}\text { Slave } \\
\text { Productivity }\end{array}$ & $\begin{array}{l}\text { Cost } \\
\text { (réis) }\end{array}$ \\
\hline 1809 & 85.5 & 5.3 & 190,000 & 12.0 & 2918 \\
\hline 1810 & 85.2 & 5.4 & 187,952 & 12.0 & 2984 \\
\hline 1811 & 85.0 & 5.5 & 194,872 & 12.1 & 2990 \\
\hline 1812 & 84.8 & 5.4 & 184,000 & 12.1 & 2995 \\
\hline 1813 & 84.5 & 5.4 & 216,651 & 12.1 & 3279 \\
\hline 1814 & 85.8 & 5.3 & 205,455 & 12.2 & 3028 \\
\hline 1815 & 87.2 & 5.5 & 167,500 & 12.2 & 3055 \\
\hline 1816 & 88.7 & 5.5 & 256,593 & 12.2 & 3082 \\
\hline 1817 & 90.1 & 5.6 & 245,248 & 12.2 & 3109 \\
\hline 1818 & 91.6 & 5.5 & 277,179 & 12.3 & 3136 \\
\hline 1819 & 93.1 & 5.5 & 259,348 & 12.3 & 3163 \\
\hline 1820 & 94.6 & 5.5 & 217,321 & 12.3 & 3189 \\
\hline 1821 & 96.1 & 5.4 & 228,378 & 12.4 & 3228 \\
\hline 1822 & 97.7 & 5.6 & 218,398 & 12.4 & 3267 \\
\hline 1823 & 99.2 & 5.5 & 208,417 & 12.4 & 3306 \\
\hline 1824 & 100.9 & 5.5 & 214,824 & 12.5 & 3345 \\
\hline 1825 & 102.5 & 5.4 & 177,931 & 12.5 & 3384 \\
\hline 1826 & 104.2 & 5.6 & 219,848 & 12.5 & 3422 \\
\hline 1827 & 105.9 & 5.5 & 261,765 & 12.6 & 3460 \\
\hline 1828 & 107.6 & 5.4 & 207,757 & 12.6 & 3498 \\
\hline 1829 & 109.3 & 5.8 & 153,750 & 12.6 & 3535 \\
\hline 1830 & 111.1 & 5.8 & 247,143 & 12.6 & 3573 \\
\hline 1831 & 112.9 & 5.8 & 346,489 & 12.7 & 3610 \\
\hline 1832 & 114.7 & 6.0 & 350,000 & 12.7 & 3647 \\
\hline 1833 & 116.6 & 6.0 & 358,333 & 12.7 & 3725 \\
\hline 1834 & 118.5 & 6.2 & 366,667 & 12.8 & 3802 \\
\hline 1835 & 120.4 & & 375,000 & 12.8 & 3878 \\
\hline 1836 & 122.4 & & 383,333 & 12.8 & 3955 \\
\hline 1837 & 124.4 & & 391,667 & 12.9 & 4031 \\
\hline 1838 & 126.4 & & 400,000 & 12.9 & 4106 \\
\hline 1839 & 128.4 & & 408,333 & 12.9 & 4181 \\
\hline 1840 & 130.5 & 6.4 & 416,667 & 13.0 & 4256 \\
\hline 1841 & 132.7 & 6.4 & 425,000 & 13.0 & 4330 \\
\hline 1842 & 134.8 & 5.7 & 433,333 & 13.0 & 4404 \\
\hline 1843 & 137.0 & 6.2 & 441,667 & 13.1 & 4477 \\
\hline 1844 & 139.2 & 6.4 & 450,000 & 13.1 & 4551 \\
\hline 1845 & 141.5 & 6.1 & 458,333 & 13.1 & 4623 \\
\hline 1846 & 143.8 & 6.1 & 466,667 & 13.2 & 4696 \\
\hline 1847 & 146.1 & 6.4 & 475,000 & 13.2 & 4768 \\
\hline 1848 & 148.5 & 6.3 & 483,333 & 13.2 & 4839 \\
\hline 1849 & 150.9 & 6.3 & 491,667 & 13.3 & 4910 \\
\hline 1850 & 153.4 & 6.3 & 500,000 & 13.3 & 4981 \\
\hline 1851 & 155.9 & 6.4 & 490,000 & 13.3 & 4869 \\
\hline
\end{tabular}




\begin{tabular}{llllll}
1852 & 158.4 & 6.5 & 480,000 & 13.4 & 4758 \\
1853 & 161.0 & 6.3 & 470,000 & 13.4 & 4647 \\
1854 & 162.6 & 6.3 & 460,000 & 13.4 & 4537 \\
1855 & 165.2 & 6.2 & 450,000 & 13.5 & 4427 \\
1856 & 167.9 & 8.7 & 440,000 & 13.5 & 4318 \\
1857 & 170.7 & 6.2 & 430,000 & 12.0 & 4210 \\
1858 & 173.4 & 6.5 & 420,000 & 12.0 & 4101 \\
1859 & 176.3 & 6.1 & 410,000 & 12.1 & 3994 \\
1860 & 179.1 & 6.0 & 400,000 & 12.1 & 3887 \\
\hline
\end{tabular}

Sources: See Chapter 4. 
Table A.6 - Cotton taxes in Maranhão per arroba, 1809-1850

\begin{tabular}{|c|c|c|c|c|c|c|}
\hline Year & Dízimo & $\begin{array}{l}600 \text { réis } \\
\operatorname{tax}(1808)\end{array}$ & $\begin{array}{l}100 \text { réis per } \\
\text { bag (1809) }\end{array}$ & $\begin{array}{l}\text { Silver } \\
\text { premium in } \\
\text { Maranhão }\end{array}$ & Tax rate & $\begin{array}{l}\text { Effective } \\
\text { tax rate }\end{array}$ \\
\hline 1809 & 0.10 & 600 & & & 0.25 & 0.25 \\
\hline 1810 & 0.10 & 600 & & & 0.26 & 0.26 \\
\hline 1811 & 0.10 & 600 & & & 0.28 & 0.28 \\
\hline 1812 & 0.10 & 600 & & & 0.30 & 0.30 \\
\hline 1813 & 0.10 & 600 & & & 0.26 & 0.26 \\
\hline 1814 & 0.07 & 600 & & & 0.20 & 0.20 \\
\hline 1815 & 0.08 & 600 & & & 0.18 & 0.18 \\
\hline 1816 & 0.08 & 600 & 17.9 & & 0.18 & 0.18 \\
\hline 1817 & 0.08 & 600 & 17.9 & & 0.16 & 0.16 \\
\hline 1818 & 0.08 & 600 & 17.9 & & 0.16 & 0.16 \\
\hline 1819 & 0.08 & 600 & 17.9 & & 0.16 & 0.16 \\
\hline 1820 & 0.08 & 600 & 17.9 & & 0.20 & 0.20 \\
\hline 1821 & 0.07 & 600 & 17.9 & & 0.22 & 0.22 \\
\hline 1822 & 0.07 & 600 & 17.9 & & 0.23 & 0.23 \\
\hline 1823 & 0.06 & 600 & 17.9 & & 0.24 & 0.24 \\
\hline 1824 & 0.07 & 600 & 17.9 & & 0.22 & 0.22 \\
\hline 1825 & 0.08 & 600 & 17.9 & & 0.19 & 0.19 \\
\hline 1826 & 0.07 & 600 & 17.9 & & 0.21 & 0.21 \\
\hline 1827 & 0.06 & 600 & 17.9 & & 0.24 & 0.24 \\
\hline 1828 & 0.06 & 600 & 17.9 & & 0.25 & 0.25 \\
\hline 1829 & 0.05 & 600 & 17.9 & 24.00 & 0.27 & 0.27 \\
\hline 1830 & 0.06 & 600 & 17.9 & 44.00 & 0.25 & 0.25 \\
\hline 1831 & 0.12 & & 17.9 & 45.00 & 0.13 & 0.18 \\
\hline 1832 & 0.12 & & 17.9 & 45.00 & 0.12 & 0.18 \\
\hline 1833 & 0.12 & & 17.9 & 70.00 & 0.12 & 0.18 \\
\hline 1834 & 0.12 & & & 87.27 & 0.12 & 0.20 \\
\hline 1835 & 0.12 & & & 70.00 & 0.12 & 0.22 \\
\hline 1836 & 0.05 & & & 70.15 & 0.12 & 0.16 \\
\hline 1837 & 0.06 & & & 80.70 & 0.13 & 0.17 \\
\hline 1838 & 0.05 & & & 80.21 & 0.12 & 0.16 \\
\hline 1839 & 0.05 & & & 77.46 & 0.12 & 0.16 \\
\hline 1840 & 0.05 & & & 69.67 & 0.12 & 0.16 \\
\hline 1841 & 0.05 & & & 88.04 & 0.12 & 0.15 \\
\hline 1842 & 0.05 & & & 100.77 & 0.12 & 0.16 \\
\hline 1843 & 0.05 & & & 104.82 & 0.12 & 0.17 \\
\hline 1844 & 0.03 & & & 106.23 & 0.10 & 0.13 \\
\hline 1845 & 0.03 & & & 102.69 & 0.10 & 0.13 \\
\hline 1846 & 0.03 & & & 24.00 & 0.10 & 0.13 \\
\hline 1847 & 0.05 & & & & 0.12 & 0.12 \\
\hline 1848 & 0.05 & & & & 0.12 & 0.12 \\
\hline 1849 & 0.05 & & & & 0.12 & 0.12 \\
\hline 1850 & 0.05 & & & & 0.12 & 0.12 \\
\hline
\end{tabular}

Notes: Between 1814 and 1830, the dízimo had a deduction to account for transport costs. In the "silver premium" series there is no data for 1831 and 1832. The effective tax rate adds the silver premium. 
Table A.7 - Break Points in Cotton Consumption in Liverpool, 1821-1860

\begin{tabular}{|c|c|c|}
\hline \multirow{2}{*}{$\frac{\text { Break weeks }(\mathrm{Ti})}{1 \text { February } 1823}$} & Boundary months for $90 \%$ confidence interval & Proportional change \\
\hline & [29 December 1821 - 19 April 1823] & $+42.0 \%$ \\
\hline 16 April 1829 & [5 September 1828 - 23 October 1829] & $+40,5 \%$ \\
\hline 26 May 1837 & [9 December 1836 - 13 October 1837] & $+35,9 \%$ \\
\hline 4 November 1842 & [16 July $1841-18$ August 1843] & $+19,2 \%$ \\
\hline 20 April 1849 & [11 February $1848-3$ August 1849 ] & $+29,2 \%$ \\
\hline 6 January 1854 & [18 February $1853-4$ August 1854$]$ & $+30,1 \%$ \\
\hline Parameter & $\beta \quad$ Cor & ted Standard Errors \\
\hline$\beta 1$ & $7,580.1$ & $425.1 * * *$ \\
\hline$\beta 2$ & $10,768.1$ & $457.2 * * *$ \\
\hline$\beta 3$ & $15,138.2$ & $426.1 * * *$ \\
\hline$\beta 4$ & $20,584.0$ & $561.0 * * *$ \\
\hline$\beta 5$ & $24,549.5$ & $623.4 * * *$ \\
\hline$\beta 6$ & $31,683.0$ & $1237.6 * * *$ \\
\hline$\beta 7$ & $41,250.2$ & $1183.9 * * *$ \\
\hline \multirow{4}{*}{$\begin{array}{l}\mathrm{R}^{\wedge} 2: 0.52 \\
\mathrm{~F}(7,2076): 324.43 \\
\mathrm{n}=2,083 \\
* * * \text { significant at } 1 \% \text { level }\end{array}$} & Number of breaks selected by: & \\
\hline & $\operatorname{supF}(\mathrm{L}+1 / \mathrm{L})$ test $=6$ & \\
\hline & Sequential procedure $=6$ & \\
\hline & Repartition procedure $=6$ & \\
\hline
\end{tabular}


Table A.8 - Break Points in weekly cotton receipts in Liverpool, 1821-1860 (bales)

\begin{tabular}{|c|c|c|c|}
\hline & United States & East Indies & Egypt \\
\hline Break & 23 February 1827 & 28 September 1832 & 23 October 1840 \\
\hline \multirow[t]{2}{*}{ Weeks } & 25 April 1833 & 19 July 1839 & 19 July 1844 \\
\hline & 31 December 1840 & 17 September 1852 & $\begin{array}{c}18 \text { September } 1846 \\
11 \text { May } 1849\end{array}$ \\
\hline \multirow{4}{*}{$\begin{array}{l}\text { Boundary } \\
\text { months } \\
(90 \% \text { C.I) }\end{array}$} & [Oct. 1825 - Jun. 1827] & [Nov. 1831 - Oct. 1832] & [Jul. 1837 - Apr. 1847] \\
\hline & [Jan. 1832 - Oct. 1833] & [Oct. 1837 - Nov. 1839] & [Oct. 1843 - Oct. 1844] \\
\hline & [Aug. 1840 - Apr. 1843] & [Jan 1852 - Oct 1852] & [Aug. 1846 - Mar. 1847] \\
\hline & & & [Jul. 1848 - May. 1849] \\
\hline$\beta$ - Parameters & $6,117(403.1)^{* * *}$ & $275(36.5)^{*}$ & $447(41.7)^{* * *}$ \\
\hline \multirow[t]{4}{*}{ (Corrected S.E) } & $10,409(647.9)^{* * *}$ & $1,228(114.6)^{* * *}$ & $639(68.4)^{* * *}$ \\
\hline & $16,367(1056.0)^{* * *}$ & $2,469(156.2)^{* * *}$ & $1,351(145.3)^{* * *}$ \\
\hline & $27,947(1480.2)^{* * *}$ & $7,019(431.4)^{* * *}$ & $441(70.8)^{* * *}$ \\
\hline & & & $2,031(140.3) * * *$ \\
\hline
\end{tabular}

\begin{tabular}{|c|c|c|c|}
\hline \multicolumn{4}{|l|}{ N. of Breaks: } \\
\hline $\operatorname{supF}(\mathrm{L}+1 / \mathrm{L})$ & 3 & 4 & 4 \\
\hline Sequential & 3 & 3 & 4 \\
\hline Repartition & 3 & 3 & 4 \\
\hline $\mathrm{R}^{\wedge} 2$ & 0.13 & 0.25 & 0.14 \\
\hline N. of Obs. & 2,083 & 2,083 & 2,083 \\
\hline
\end{tabular}

Note: With a 5 percent trimming on the series, the minimum interval length between breaks is 104 weeks. Breaks are for the last date of the old regime. Output from the estimation of the model selected by the sequential method. Boundary months are for 90 percent confidence intervals. $* * *$ significant at 1 percent level. 
Table A.9 - Break Points in Upland cotton prices at New York Port, 1816-1860 (U\$)

\begin{tabular}{ccc} 
Break weeks (Ti) & $\begin{array}{c}\text { Boundary months for 90\% confidence } \\
\text { interval }\end{array}$ & Proportional change \\
\hline 23 April 1819 & [24 December 1816 - 10 March 1820] & $-60.5 \%$ \\
\hline Parameter & 28.88 & Corrected Standard Errors \\
\hline$\beta 1$ & 11.40 & $3.54^{* * *}$ \\
$\beta 2$ & Number of breaks selected by: & \\
$\mathrm{R}^{\wedge} 2: 0.68$ & supF(L+1/L) test $=1$ & \\
$\mathrm{~F}(2,4685): 5053.7$ & Sequential procedure $=1$ & \\
$\mathrm{n}=4,687$ & Repartition procedure $=1$ & \\
$* * *$ significant at $1 \%$ level & & \\
\hline
\end{tabular}

Note: With a 5 percent trimming on the series, the minimum interval length between breaks is 234. Breaks are for the last date of the old regime. Output from the estimation of the model selected by the sequential method. 
Table A.10 - Cotton demand elasticity, seemingly unrelated regression (SUR)

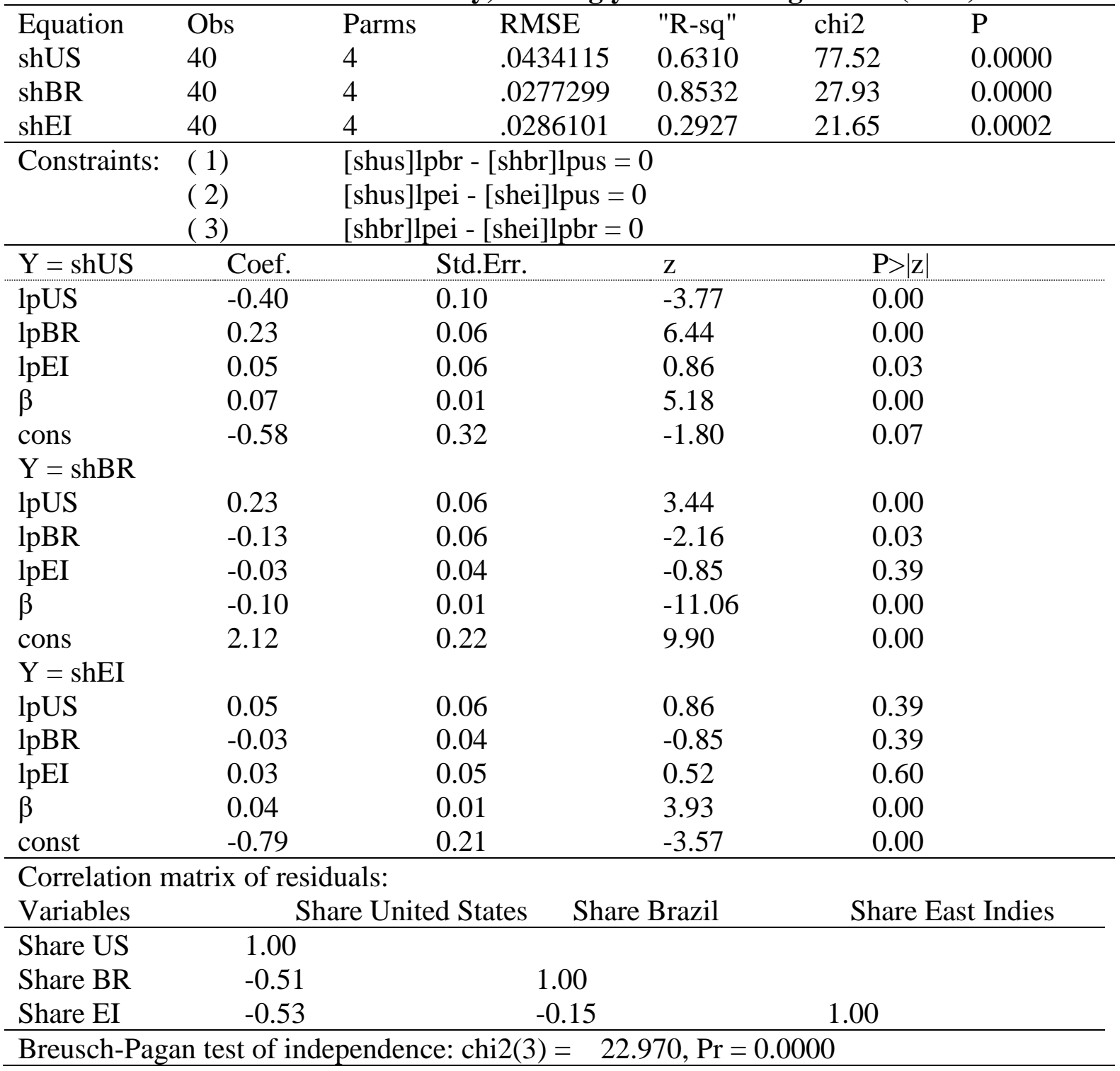


Table A.11 - Cotton demand elasticity, IV (2SLS) estimation

\begin{tabular}{|c|c|c|c|c|}
\hline \multicolumn{5}{|c|}{ First-stage regression } \\
\hline $\mathrm{Y}=1 \mathrm{pbr}$ & Coef. & Std.Err. & $\mathrm{t}$ & $\mathrm{P}>|\mathrm{t}|$ \\
\hline Cost & 0.40 & 0.10 & 3.96 & 0.00 \\
\hline lpUS & 0.51 & 0.16 & 3.19 & 0.00 \\
\hline ltax & -0.06 & 0.05 & -1.11 & 0.27 \\
\hline lpEI & -0.09 & 0.13 & 0.75 & 0.46 \\
\hline$\beta$ & -0.10 & 0.03 & -3.44 & 0.00 \\
\hline const & 2.55 & 0.60 & 4.26 & 0.00 \\
\hline \multicolumn{5}{|c|}{ Observations $=40$} \\
\hline \multicolumn{5}{|c|}{ F test of excluded instruments } \\
\hline \multicolumn{5}{|c|}{ Sanderson-Windmeijer F test of excluded instruments $\quad F(1,34)=15.65$} \\
\hline \multirow{3}{*}{\multicolumn{5}{|c|}{$\begin{array}{l}\text { Underidentification test: } \\
\text { Ho: matrix of reduced form coefficients has rank=K1-1 (underidentified) } \\
\text { Ha: matrix has rank=K1 (identified) }\end{array}$}} \\
\hline & & & & \\
\hline & & & & \\
\hline \multicolumn{5}{|c|}{ Anderson canon. corr. LM statistic $\quad$ Chi-sq $(1)=12.61 \quad \mathrm{P}-\mathrm{val}=0.0004$} \\
\hline \multirow{3}{*}{\multicolumn{5}{|c|}{$\begin{array}{l}\text { Weak identification test } \\
\text { Ho: equation is weakly identified } \\
\text { Cragg-Donald Wald F statistic: } 15.65\end{array}$}} \\
\hline & & & & \\
\hline & & & & \\
\hline \multicolumn{5}{|c|}{ (2SLS) regression $-\mathrm{IV}:$ Cost } \\
\hline$Y=\operatorname{shBR}$ & Coef. & Std.Err. & $\mathrm{Z}$ & $\mathrm{P}>|\mathrm{z}|$ \\
\hline lpBR & -0.28 & 0.10 & -2.70 & 0.00 \\
\hline lpUS & 0.32 & 0.10 & 3.21 & 0.00 \\
\hline ltax & 0.06 & 0.02 & 3.01 & 0.00 \\
\hline lpEI & -0.04 & 0.05 & -0.77 & 0.44 \\
\hline$\beta$ & -0.09 & 0.01 & -8.03 & 0.00 \\
\hline const & 2.10 & 0.26 & 8.03 & 0.00 \\
\hline \multicolumn{5}{|c|}{$\begin{array}{l}\text { Observations }=40 \quad \text { Centered } \mathrm{R}^{\wedge} 2=0.86 \\
\text { Underidentification test (Anderson canon. corr. LM statistic): } 12.60 \\
\text { Chi-sq(1) P-val }=0.0004\end{array}$} \\
\hline
\end{tabular}

